\title{
EMPREGO DO GEOPROCESSAMENTO NO ESTUDO DA RELAÇÃO ENTRE POTENCIAL PRODUTIVO DE UM POVOAMENTO DE EUCALIPTO E ATRIBUTOS DO SOLO E DO RELEVO
}

\author{
JONAS LUÍS ORTIZ
}

Dissertação apresentada à Escola Superior de Agricultura "Luiz de Queiroz", Universidade de São Paulo, para obtenção do título de Mestre em Recursos Florestais, com opção em Silvicultura e Manejo Florestal.

PIRACICABA

Estado de São Paulo - Brasil

Agosto - 2003 


\section{EMPREGO DO GEOPROCESSAMENTO NO ESTUDO DA RELAÇÃO ENTRE POTENCIAL PRODUTIVO DE UM POVOAMENTO DE EUCALIPTO E ATRIBUTOS DO SOLO E DO RELEVO}

\section{JONAS LUÍS ORTIZ}

Geógrafo

\section{Orientador: Prof. Dr. CARLOS ALBERTO VETTORAZZI}

Dissertação apresentada à Escola Superior de Agricultura "Luiz de Queiroz", Universidade de São Paulo, para obtenção do título de Mestre em Recursos Florestais, com opção em Silvicultura e Manejo Florestal.

PIRACICABA

Estado de São Paulo - Brasil

Agosto - 2003 


\section{Dados I nternacionais de Catalogação na Publicação (CI P)}

DI V SÃO DE BI BLIOTECAE DOCUMENTAÇÃO - ESALQ/ USP

\section{Ortiz, J onas Luís}

Emprego do geoprocessamento no estudo da relação entre potencial produtivo de um povoamento de eucalipto e atributos do solo e do relevo / J onas Luís Ortiz. - - Piracicaba, 2003.

205 p. : il. 2003.

Dissertação (mestrado) - - Escola Superior de Agricultura Luiz de Queiroz, Bibliografia.

1. Eucalipto 2. Geoestatística 3. Geoprocessamento 4. Povoamento florestal 5. Relação solo-planta 6. Silvicultura de precisão 7. Variabilidade espacial I. Título

CDD 634.9734 


\section{AGRADECIMENTOS}

Agradeço primeiramente ao grandioso Pai, que me ofertou sabedoria, saúde e a oportunidade de estar aqui, assim como por iluminar o meu caminho com amigos e pessoas especiais. Sempre permaneça junto a mim.

Aos meus pais e meus cinco irmãos, pela credibilidade e esperança depositada em mim, assim como à Fernanda Maniero pelo carinho e incentivo durante estes seis anos.

À Escola Superior de Agricultura "Luiz de Queiroz", em particular ao Departamento de Ciência Florestais, em especial, ao Coordenador do Programa de PósGraduação em Recursos Florestais Prof. Dr. Luiz Carlos Estraviz Rodriguez e ao Prof. Dr. Carlos Alberto Vettorazzi, pela oportunidade de realização deste curso.

Ao professor, orientador e amigo Dr. Carlos Alberto Vettorazzi, pela orientação, atenção, incentivo, confiança e pelos ensinamentos repassados ao longo deste trabalho.

Aos professores, Dr. Hilton Thadeu Zarate do Couto (Bioestatística e Inventário Florestal) e Dr. José Leonardo de Moraes Gonçalves (Solos eNutrição de Plantas), pela valiosa orientação e colaboração, assim como pelas inúmeras sugestões apresentadas.

À professora Dra. Maria Isabel Casthegrini de Freitas (Sensoriamento Remoto e Geoprocessamento), pela confiança depositada em mim e pelas oportunidades oferecidas durante minha graduação, assim como pelos ensinamentos, tão importantes e valiosos, repassados ao longo de meu trabalho de Iniciação Científica na UNESP/Rio Claro.

À Suzano Bahia Sul Celulose pela oportunidade e pelos recursos financeiros, humanos e técnicos concedidos, tornando possível a realização deste trabalho. 
Aos funcionários da Suzano Bahia Sul Celulose, em especial, à Coordenadora de Planejamento, Inventário e Pesquisa Enga. Lucimara Roncolato, ao Engenheiro Florestal Alexandre Pereira (Departamento de Recursos Naturais), ao Técnico e Supervisor Florestal Sérgio Ferrares e ao Encarregado de Silvicultura Vicente Belarmino, pela amizade, respeito, atenção e disponibilidade oferecida, assim como pelos esforços, sempre atendendo as solicitações apresentadas.

Aos funcionários da Suzano Bahia Sul Celulose que ajudaram na condução dos trabalhos de campo, medição das árvores e capina, em especial Adão e Jorge.

Ao funcionário do Departamento de Engenharia Rural da ESALQ/USP, Jesuíno Ferrari, pelo empenho e coordenação dos trabalhos de topografia na área experimental.

Ao Biólogo André Fernando Cleto e ao Engenheiro Agrônomo Genelício Cruzoé Rocha, que ajudaram na condução dos trabalhos de campo.

À Coordenação de Aperfeiçoamento de Pessoal de Nível Superior (CAPES), pela concessão da bolsa de estudos, fundamental para o bom andamento e conclusão deste trabalho. 


\section{SUMÁRIO}

Página

LISTA DE FIGURAS.................................................................................. vii

LISTA DE TABELAS............................................................................. $\mathrm{x}$

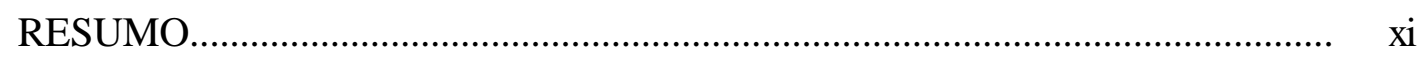

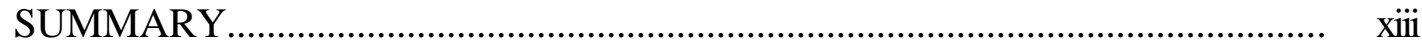

1 INTRODUÇÃO

2 REVISÃO DE LITERATURA.................................................................. 5

2.1 Produtividade do eucalipto................................................................................ 5

2.2 Classificação da qualidade de sítios florestais..................................................... 7

2.3 Inventário florestal.................................................................................... 13

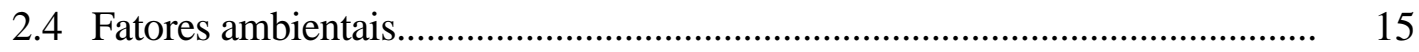

2.4.1 Características fisiográficas......................................................................... 16

2.4.1.1 Face de exposição............................................................................................. 16

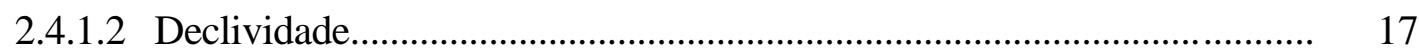

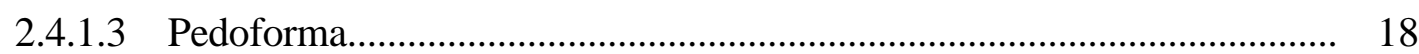

2.4.1.4 Profundidade do solo............................................................................. 19

2.4.1.5 Altitude.................................................................................. 20

2.4.2 Deficiência hídrica do solo........................................................................ 21

2.4.3 Características físicas do solo......................................................................... 23

2.4.4 Características químicas do solo............................................................... 27

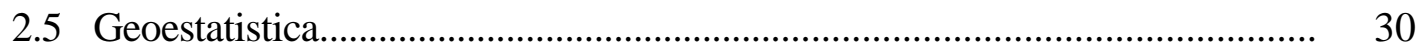

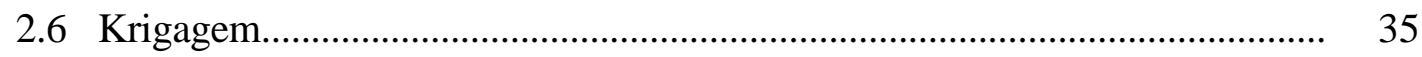

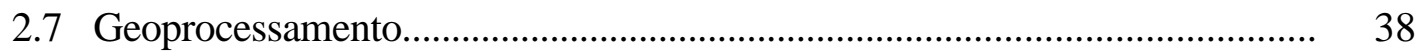


2.7.1 Mapeamento digital. ..................................................................................... 39

2.8 Relação entre produtividade e atributos do solo e do relevo............................... $\quad 40$

2.8.1 Aplicação da estatística clássica na área florestal.......................................... 40

2.8.2 Aplicação da geoestatística e do geoprocessamento na área florestal........... 51

2.8.3 Aplicação da geoestatística e do geoprocessamento na área agrícola............ 56

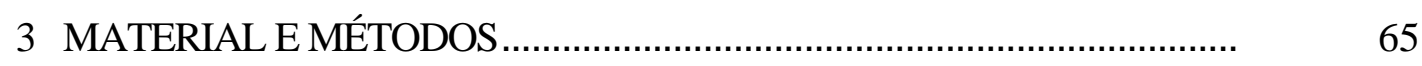

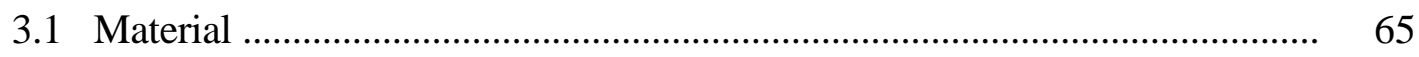

3.1.1 Caracterização da área de estudo................................................................ 65

3.1.2 Equipamentos.................................................................................. 69

3.1.3. Mapas e programas..................................................................................... 69

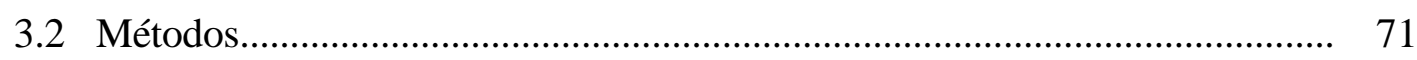

3.2.1 Instalação da grade amostral..................................................................... 71

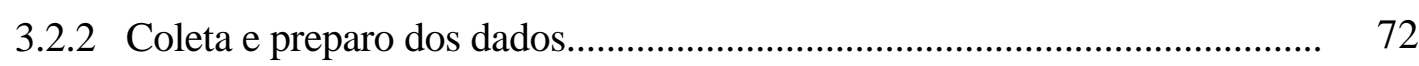

3.2.3 Matriz de correlação e regressão.............................................................

3.2.4 Análise geoestatística........................................................................... 78

3.2.5 Mapeamento da variabilidade espacial e regressão espacial............................ $\quad 80$

4 RESULTADOS E DISCUSSÃO...........................................................

4.1 Análises dos dados coletados........................................................................ 87

4.2 Estatística clássica...................................................................................... 87

4.2.1 Matriz de correlação................................................................................... 87

4.2.2 Regressão linear simples......................................................................... 92

4.2.3 Regressão linear múltipla........................................................................... 99

4.3 Estatística espacial...................................................................................... 101

4.3.1 Resumo estatístico e análise exploratória dos dados....................................... 101

4.3.2 Semivariogramas experimentais..................................................................... 124

4.3.3 Validação dos modelos ajustados............................................................... 139

4.3.4 Mapeamento digital...................................................................................... 144

4.3.5 Regressão entre mapas............................................................................. 159

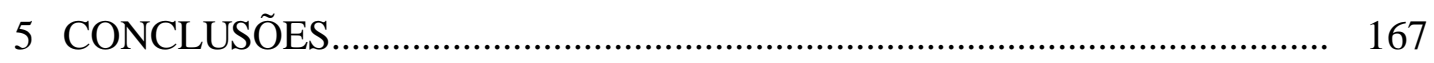

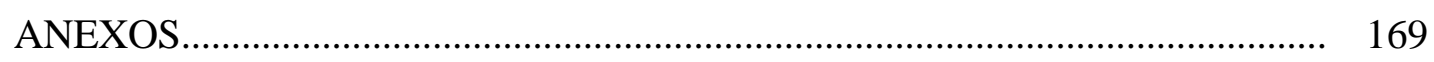

REFERÊNCIAS BIBLIOGRÁFICAS............................................................... 176 


\section{LISTA DE FIGURAS}

Página

1 Relação entre altura das árvores e posição topográfica................................... 3

2 Diferentes configurações de vizinhança....................................................... 36

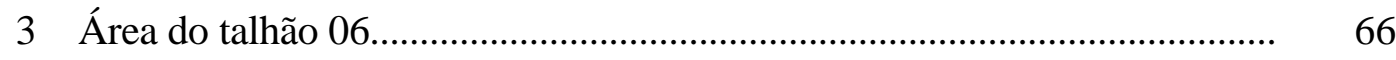

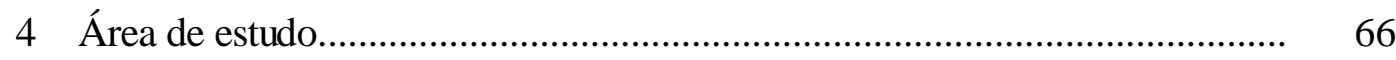

5 Precipitação pluviométrica e temperaturas médias no período de 1986 a 1996 no município de Paraibuna (SP).............................................................. 68

6 Distribuição dos pontos amostrais na área de estudo......................................

7 Gráficos de probabilidade normal para $\mathrm{Cu}$........................................................ 105

8 Gráficos de probabilidade normal para ArMG............................................... 106

9 Gráficos de probabilidade normal para Ca....................................................... 107

10 Gráficos de probabilidade normal para V\% ................................................... 108

11 Histograma de probabilidade normal para $\mathrm{Mg}$ e B....................................... 109

12 Histograma de probabilidade normal e gráfico de caixa para m\%.................. 110

13 Histograma de probabilidade normal e gráfico de caixa para Mn.................. 111

14 Gráfico de probabilidade normal e de caixa para $\mathrm{pH}$...................................... 113

15 Gráfico de ramos e folhas para $\mathrm{pH}$................................................................ 114

16 Gráfico de ramos e folhas para MO............................................................. 114

17 Gráfico de probabilidade normal e de caixa para MO.................................. 115

18 Gráfico de probabilidade normal e de caixa para P....................................... 116

19 Gráfico de ramos e folhas para P.............................................................. 117

20 Gráfico de distribuição espacial para pH.................................................... 118

21 Gráfico de distribuição espacial para MO...................................................... 118 
22 Gráfico de distribuição espacial para $\mathrm{P}$

23 Gráfico de distribuição espacial para m\%

24 Histograma de probabilidade normal e gráfico de caixa para $\mathrm{m} \%$ sem o valor influente.

25 Gráfico de probabilidade normal para V\% sem o valor influente.

26 Semivariogramas escalonados de ArMF, ArF e ArM

27 Semivariogramas escalonados de AreG, ArMG e AreT..

28 Semivariogramas escalonados de ArgT, SilArg e Silte.

29 Semivariogramas escalonados de ArgA, Floc e pH.

30 Semivariogramas escalonados de Cotas, Umidade e IS

31 Semivariogramas escalonados de $\mathrm{Al}, \mathrm{H}+\mathrm{Al}$ e $\mathrm{m} \%$

32 Semivariogramas escalonados de $\mathrm{Ca}, \mathrm{Mg}$ e $\mathrm{Mn}$

33 Semivariogramas escalonados de $\mathrm{V} \%, \mathrm{SB}$ e Fe

34 Semivariogramas escalonados de CTC, T e S

35 Semivariogramas escalonados de $\mathrm{P}, \mathrm{K}$ e Zn.

36 Semivariogramas escalonados de $\mathrm{Cu}, \mathrm{B}$ e $\mathrm{MO}$.

37 Mapa dos erros da validação cruzada para Cotas.

38 Gráfico do erro de estimativa para Cotas........................................................ 142

39 Gráfico do erro de estimativa para Cotas.......................................................... 143

40 Regressão linear entre os valores observados e estimados para Cotas............ 144

41 Distribuição espacial de ArgT e AreT na área de estudo................................ 145

42 Distribuição espacial de ArMG e Cotas na área de estudo............................ 146

43 Distribuição espacial de ArMF e ArF na área de estudo................................. 147

44 Distribuição espacial de ArM e AreG na área de estudo................................. 148

45 Distribuição espacial de Floc e ArgA na área de estudo................................ 149

46 Distribuição espacial de Silte e SilAr na área de estudo................................ 150

47 Distribuição espacial de Umi e IS na área de estudo...................................... 151

48 Distribuição espacial de $\mathrm{pH}, \mathrm{K}, \mathrm{Mn}$ e Zn na área de estudo........................... 152

49 Distribuição espacial de SB, Mg, V\% e m\% na área de estudo...................... 153

50 Distribuição espacial de H+Al, T, Al e P na área de estudo........................... 154 
51 Distribuição espacial de S, CTC, Fe e Cu na área de estudo.

52 Localização das classes de declividade, em graus e porcentagem, na área de estudo.

53 Localização das faces de exposição e distribuição espacial de Ca na área de estudo.

54 Resultado da regressão linear simples espacial entre IS e face de exposição

55 Mapas de isolinhas com os valores de IS preditos pelo $1^{0}$ modelo (a), pelo $2^{\mathrm{o}}$ modelo (b) e mapa de isolinhas com os valores de IS estimados (c).......... 


\section{LISTA DE TABELAS}

\section{Página}

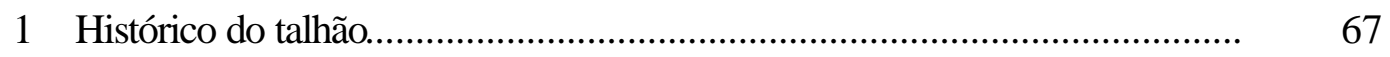

2 Classes de exposição de vertentes................................................................. 81

3 Classes clinográficas (em porcentagem) ........................................................... 82

4 Classes clinográficas (em graus)................................................................

5 Matriz de correlação com o conjunto de dados originais, sem as observações influentes.

6 Resultado da análise de regressão simples, sem violação das suposições, entre o IS e as variáveis independentes.................................................... 93

7 Resultado da análise de regressão simples com violação das suposições.... 94

8 Resultado da análise de regressão simples com correção das violações...... 94

9 Análise de variância do $1^{0}$ modelo de regressão múltipla selecionado......... 99

10 Análise de variância do 2º modelo de regressão múltipla selecionado......... 100

11 Resumo estatístico................................................................................. 102

12 Valores do teste de Kolmogorov-Smirnov............................................... 104

13 Resumo estatístico.............................................................................. 122

14 Parâmetros dos semivariogramas ajustados para as variáveis estudadas..... 125

15 Resultados dos parâmetros da validação cruzada para cada atributo .......... $\quad 140$

16 Resultado da análise de regressão linear simples, pixel-a-pixel................... 161

17 Análise de variância do $1^{\text {oo }}$ modelo de regressão múltipla espacial

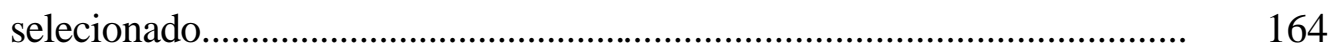

18 Análise de variância do $2^{\underline{o}}$ modelo de regressão múltipla espacial selecionado 


\title{
EMPREGO DO GEOPROCESSAMENTO NO ESTUDO DA RELAÇÃO ENTRE POTENCIAL PRODUTIVO DE UM POVOAMENTO DE EUCALIPTO E ATRIBUTOS DO SOLO E DO RELEVO
}

\author{
Autor: JONAS LUÍS ORTIZ \\ Orientador: Prof. Dr. CARLOS ALBERTO VETTORAZZI
}

\section{RESUMO}

O presente trabalho teve como objetivo principal a aplicação de uma metodologia, empregando técnicas de estatística clássica, geoestatística e geoprocessamento, para o mapeamento da variabilidade espacial do potencial produtivo em um talhão com clones de Eucalypt us grandis, aos 6,3 anos de idade, e analisar sua relação com atributos do solo e do relevo, dentro de uma abordagem denominada Silvicultura de Precisão. A investigação foi conduzida numa área de 8,4 ha, com relevo acidentado, pertencente à Suzano Bahia Sul Celulose, em Paraibuna, SP. Foi instalada, na área experimental, uma grade irregular totalizando 41 pontos amostrais, nos quais foram coletados dados referentes às suas coordenadas planas, para georreferenciamento da área de estudo; cotas altimétricas; atributos da planta, mais especificamente DAP e altura total; e amostras de solo na profundidade de $0-20 \mathrm{~cm}$, para análises químicas, físicas e de umidade. Inicialmente foram realizados o resumo estatístico e a análise exploratória do conjunto de dados de cada variável, utilizando-se os pacotes estatísticos Excel, SAS e Statistica. Posteriormente foram ajustados, no GS+ e no Geoeas, semivariogramas para as variáveis, definindo-se os parâmetros necessários para a krigagem. Após isso, foi avaliado o número ideal de vizinhos para a krigagem e o erro da estimativa por meio da validação 
cruzada, utilizando-se as funções disponíveis no Geoeas. Por fim, foram gerados, no Surfer, os mapas de contorno e de superfície contínua (MDT e MDE) das variáveis em estudo. De posse dos modelos digitais das variáveis, foram determinadas estatisticamente, no SIG Idrisi, por meio de análise de correlação e regressão espacial entre mapas (regressão pixel-a-pixel), as correlações e relações entre potencial produtivo (IS) e atributos do solo e do relevo, assim como o ajuste de modelos estatísticos capazes de predizer o valor do índice de sítio por meio dos valores dos atributos do solo e do relevo. Os resultados mostraram que o melhor modelo de regressão linear múltipla espacial ajustado explicou $79 \%$ das variações do IS. Todas as variáveis apresentaram dependência espacial, exceto B e MO, sendo que o modelo esférico apresentou o melhor ajuste para os semivariogramas. Também foram determinadas estatisticamente, no Statistica e SAS, por meio de análise de correlação e regressão linear simples, que não leva em consideração a posição espacial dos dados, as correlações e relações entre IS e atributos do solo e do relevo. A partir da análise de regressão linear múltipla (métodos "todas as regressões possíveis" e "passo-a-passo") foram ajustados modelos estatísticos capazes de predizer o valor de IS por meio dos valores dos atributos do solo e relevo. O melhor modelo de regressão linear múltipla ajustado explicou $65 \%$ das variações do IS. Os resultados obtidos permitiram identificar os atributos que influenciam no potencial produtivo do talhão, com destaque para: cotas e alumínio, de forma indireta; e umidade, argila total, areia total, areia muito grossa, manganês e soma de bases, de forma direta. Foram identificadas relações entre a variabilidade dos atributos estudados na área experimental, com destaque para a relação entre a distribuição de cotas, areia total, argila total e alumínio com a do Índice de Sítio; e entre a de cotas, areia total, argila total, areia muito grossa e umidade. No geral as áreas de maior potencial produtivo apresentaram menores teores de alumínio, argila total e umidade; maiores teores de manganês, soma de bases, areia total e areia muito grossa; além de ocuparem posição menos elevada no relevo, ou seja, cotas mais baixas. Este cenário determina maior porosidade e permeabilidade ao solo, beneficiando a aeração, penetração e crescimento do sistema radicular, favorecendo a absorção de nutrientes e água pelas raízes, assim como a exploração de reservas hídricas e de nutrientes das camadas subsuperfíciais do solo. 


\title{
GEOPROCESSING APPLIED TO THE STUDY OF THE RELATIONSHIP BETWEEN PRODUCTIVE POTENTIAL OF EUCALYPT AND ATTRIBUTES OF SOIL AND RELIEF
}

\author{
Author: JONAS LUÍS ORTIZ
}

Adviser: Prof. Dr. CARLOS ALBERTO VETTORAZZI

\section{SUMMARY}

The main purpose of this work was the application of a methodology, using classic statistics, geostatistics and geoprocessing techniques, to the mapping of the spatial variability of productive potential in a stand with clones of 6.3 year-old Eucalyptus grandis, and to analyze its relationship with attributes of soil and relief, by an approach denominated Precision Forestry. The investigation was carried out in an area of 8.4 ha, with hilly topography, belonging to the Suzano Bahia Sul Celulose, in Paraibuna, SP. It was installed, in the experimental area, an irregular grid totaling 41 sampling points, where data were collected related to their plane coordinates, for georreferencing of the study area; as well as altimetric data; attributes of plant, more specifically DBH and total height; and soil samples at the depht of $0-20 \mathrm{~cm}$, for chemical, physical and moisture analysis. Initially the statistical summary and the exploratory analysis of the data of each variable were accomplished, being used the statistical packages Excel, SAS and Statistica. Afterwards, the semivariograms for the variables were adjusted, in GS+ and in Geoeas, being defined the parameters needed for the kriging. After that, the ideal number of neighbors was evaluated for the kriging and the error of estimate by cross validation, being used the available functions in Geoeas. Finally, the contour maps and the 
continuous surfaces (DTM and DEM) of the studied variables were generated, in the software Surfer. With the digital models of the variables, were determined, in the GIS Idrisi, by correlation analysis and spatial regression among maps (regression pixel-bypixel), the correlations and relationships among productive potential (SI) and attributes of soil and relief, as well as the adjustment of statistical models capable to predict the value of the site index by values of the attributes of soil and relief. The results showed that the best model of adjusted spatial multiple linear regression explained $79 \%$ of the variations in the SI. All the variables presented spatial dependence, except B and OM, and the spherical model presented the best adjustment for the semivariograms. Also, the correlations and relationships between SI and attributes of soil and relief were statistically determined, in Statistica and SAS, by correlation analysis and simple linear regression, that do not take into consideration the spatial location of the data. Starting from the analysis of multiple linear regression (methods "all possible regressions" and "stepwise"), statistical models were adjusted, being capable to predict the value of SI by values of the attributes of soil and relief. The best model of adjusted multiple linear regression explained $65 \%$ of the variations in the SI. The obtained results allowed identifying the attributes that influence the productive potential of the stand, mainly: altimetric levels and aluminum, in an indirect way; and moisture, total clay, total sand, very coarse sand, manganese and sum of bases, in a direct way. Relationships were identified among the variability of the studied attributes in the experimental area, mainly the relationship among the distribution of altimetric levels, total sand, total clay and aluminum with the Site Index; and among the altimetric levels, total sand, total clay, very coarse sand and moisture. In general, areas with a higher productive potential presented lower contents of aluminum, total clay and moisture; higher contents of manganese, sum of bases, total sand and very coarse sand. They are at the lowest locations in the relief, in other words, lower altimetric levels. This scenery determines higher porosity and permeability to the soil, allowing better aeration, penetration and growth of the root system, favoring the absorption of nutrients and water by the roots, as well as the exploration of water and nutrients reserves in the subsuperficial soil layer. 


\section{INTRODUÇÃO}

O estudo da relação entre capacidade produtiva de povoamentos de eucalipto, atributos do solo e do relevo, isto é, do potencial produtivo e das principais limitações à produção de uma determinada área ou região, torna-se essencial quando se tem como objetivo o manejo racional da floresta e do solo, evitando a exaustão química e a degradação de seus atributos físicos, visando à máxima produtividade sustentável, assim como sua predição.

Uma abordagem do gerenciamento localizado das atividades silviculturais é a Silvicultura de Precisão que, segundo Vettorazzi \& Ferraz (2000), baseia-se na coleta e análise de dados geoespaciais, viabilizando intervenções localizadas na floresta, com a exatidão e a precisão adequadas. As técnicas de geoprocessamento fornecem subsídios para a identificação e a correlação das variáveis que afetam a produtividade florestal, por meio da sobreposição, cruzamento e regressão, em Sistemas de Informação Geográfica (SIGs), de mapas digitais do relevo, dos atributos do solo e da capacidade produtiva dos povoamentos.

O mapa de capacidade produtiva do povoamento pode indicar a localização de áreas críticas em termos de rentabilidade, enquanto os mapas dos atributos do solo e do relevo, por meio de seus respectivos Modelos Digitais de Elevação (MDEs), podem auxiliar na identificação dos fatores que estão limitando a capacidade produtiva, informação fundamental para a tomada de decisões. Para tanto há necessidade da utilização de modelos estatísticos capazes de predizer a capacidade produtiva do povoamento por meio, por exemplo, da estimativa do índice de sítio. ${ }^{1}$

\footnotetext{
${ }^{1}$ índice de sítio é um termo conceitualmente utilizado para expressar a altura média das árvores dominantes e codominantes conjuntamente, em uma idade específica (Carmean, 1975).
} 
Atualmente constata-se que as técnicas e metodologias de processamento e tratamento dos produtos digitais têm evoluído muito, ampliando sua capacidade de utilização e aplicabilidade, sempre no sentido de se racionalizar as soluções e custos dos projetos, apresentando-se como importantes instrumentos na detecção da variabilidade no rendimento de povoamentos florestais, monitoramento e estimativa da produtividade, enfim, no processo de planejamento da exploração dos recursos florestais.

O planejamento e o gerenciamento florestais envolvem práticas de manejo dos povoamentos florestais que, por sua vez, exigem um conhecimento simultâneo de atributos do solo, do relevo e do rendimento dos talhões. As técnicas de geoprocessamento, com o apoio da geoestatística e da estatística clássica, possibilitam o armazenamento, tratamento, cruzamento, sobreposição, análise e visualização, em conjunto, dessas informações espaciais, sob a forma de mapas digitais, o que permite tomadas de decisões rápidas, ágeis e com maior eficiência, minimizando custos, otimizando os recursos e atividades produtivas, acarretando ganho de produtividade e maximização dos lucros.

A integração entre fatores selecionados do ambiente possibilita ao silvicultor, com base na análise das informações georreferenciadas relativas a estes fatores, reconhecer e visualizar em conjunto, características distintas da floresta, permitindo relacionar a produtividade com diversos fatores e, assim, estimar a capacidade produtiva do povoamento, bem como realizar o zoneamento (da produtividade, dos atributos do solo e/ou do relevo) do mesmo, com base na qualidade de sítio ${ }^{2}$ e relação solo-sítio.

A discriminação de áreas com diferentes capacidades produtivas dentro de um único talhão e sua correlação simultânea com atributos do solo e do relevo, são subsídios imprescindíveis ao processo de reforma de talhões, uma das mais importantes variáveis do manejo florestal, assim como o mapeamento destas áreas e de cada um desses atributos em planos de informações georreferenciados.

$\overline{2}$ qualidade de sítio é a capacidade produtiva do sítio, expressa pela pela integração de todos os fatores ambientais e biológicos que influenciam no crescimento da árvore (Ralston, 1964; Gonçalves, 1988; Scolforo, 1997). 
Este trabalho foi desenvolvido em função de observações de campo, na região de estudo, onde foi constatada uma nítida variação na altura das árvores em função da posição topográfica, isto é, as árvores aumentam em tamanho à medida que ocupam cotas menores nas encostas (Figura 1).

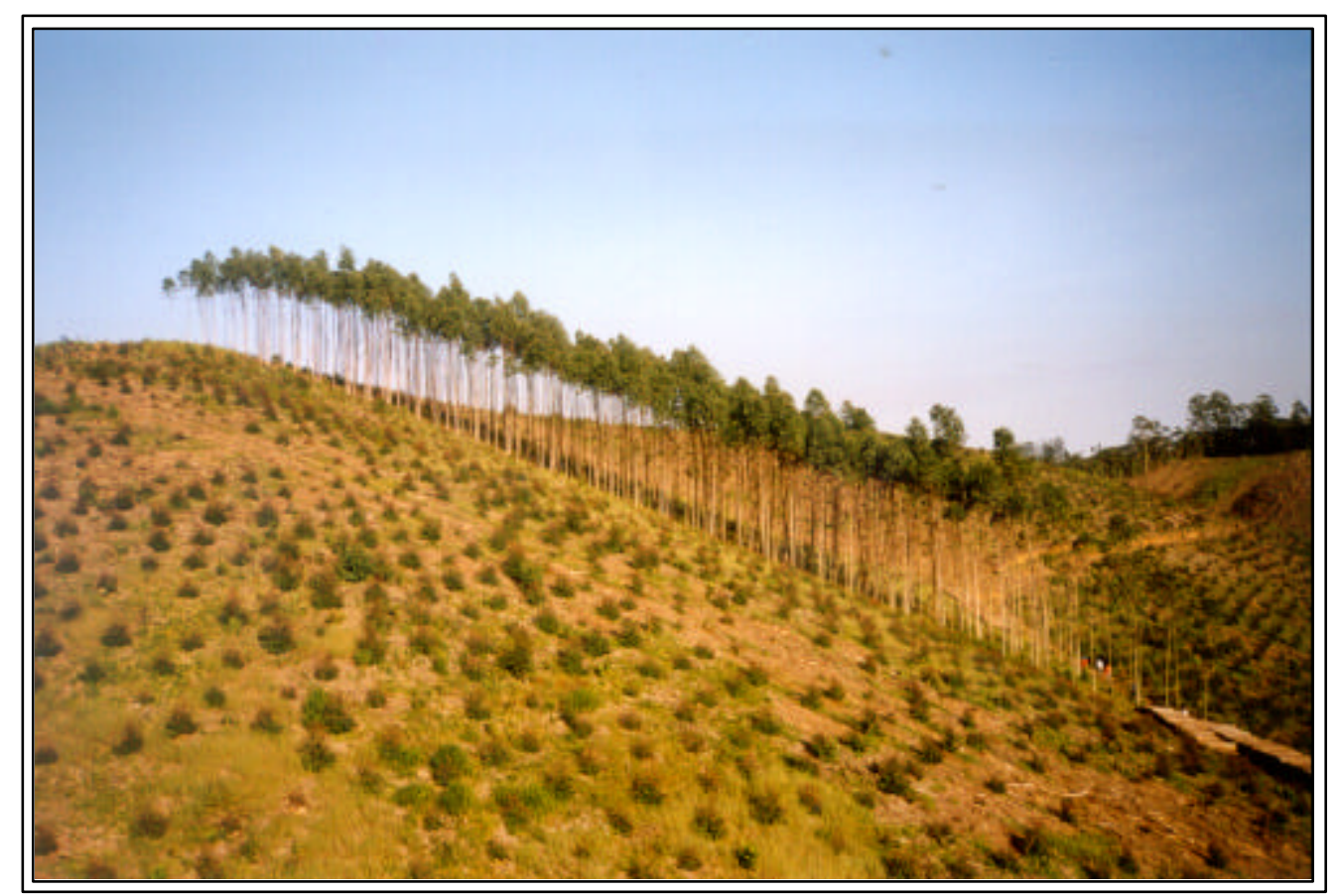

Figura 1 - Relação entre altura das árvores e posição topográfica

Fonte: Suzano Bahia Sul Celulose.

O objetivo geral deste trabalho foi a aplicação, dentro do conceito de Silvicultura de Precisão, de uma metodologia que utiliza técnicas de estatística, geoestatística e geoprocessamento, no mapeamento da variabilidade espacial da capacidade produtiva (expressa pelo índice de sítio) em um talhão de Eucalyptus grandis e sua relação com atributos de solo e de relevo. Resumidamente, o objetivo foi utilizar metodologia análoga à empregada em estudos de Agricultura de Precisão, na análise da variabilidade do potencial produtivo de eucalipto em nível de talhão. 
Os objetivos específicos deste trabalho foram:

a) mapear a variabilidade espacial de atributos do solo e do relevo e do potencial produtivo, em um talhão de Eucalyptus grandis;

b) relacionar a variabilidade dos atributos do solo e do relevo entre si e entre eles e o potencial produtivo do talhão;

c) identificar os atributos que, direta ou indiretamente, influenciam no potencial produtivo do talhão;

d) ajustar modelos estatísticos capazes de predizer o valor de IS por meio dos valores dos atributos do solo e relevo. 


\section{REVISÃO DE LITERATURA}

\subsection{Produtividade do eucalipto}

Segundo a Sociedade Brasileira de Silvicultura (1999), existem no Brasil aproximadamente 3 milhões de hectares reflorestados com espécies do gênero Eucalyptus. A expansão das áreas com cultivo do eucalipto, especialmente E. grandis, E. saligna e E. urophylla, deve-se às suas rusticidade; boa forma; adaptabilidade a diferentes gradientes climáticos, solos e altitudes; alta capacidade de regeneração natural das cepas por brotação; resistência a pragas e doenças; alta produtividade dos plantios; desenvolvimento satisfatório em solos de baixa fertilidade, em função de seu vigoroso e intenso sistema radicular, que explora maiores volumes de solo, aliado às suas baixas exigências em nutrientes e à alta tolerância a elevados níveis de alumínio (Neves, 1983 e Rojas Vergara, 1989).

Sua boa aceitação e utilização intensiva como matéria-prima para produção de celulose e energia, deve-se também ao fato de ser uma excelente matéria-prima para utilização industrial, devido à boa densidade básica de sua madeira, alto poder calorífico em relação às espécies nativas e exóticas e seu rápido crescimento (Simões \& Brandi, 1985 e Rojas Vergara, 1989).

Assmann (1961) cita diversos fatores que podem influenciar no crescimento das árvores: material genético (espécie e procedência); concorrência (espaçamento, desbastes e mortalidade natural); poda; riscos (doenças, insetos, ventos e fogo); clima (região, altitude, inclinação, exposição e precipitação); solo (geologia, pedologia, relevo e vegetação, inclinação e exposição); manejo (adubação, irrigação, utilização e queima).

Nota-se que muitos destes fatores podem ser controlados por meio do manejo 
florestal, permitindo que seja maximizada a capacidade produtiva do sítio (Schneider, 2000).

Ganhos em produtividade e em qualidade florestal por unidade de área têm sido recentemente alcançados por meio do desenvolvimento de programas de melhoramento genético, sejam eles assexuados (clonagem), sexuados (melhoramento clássico) ou integrados, obtendo resultados altamente positivos. Segundo Ramalho (1993), entre os fatores fundamentais para o sucesso desses programas, no Brasil, especialmente para as espécies de eucalipto, estão: a boa adaptação do germoplasma disponível; as características biológicas, isto é, uma planta alógama, com grande produção de sementes; os cruzamentos artificiais, até certo ponto fáceis de serem realizados; e uma propagação vegetativa viável.

Outro fator positivo alcançado por meio da implantação de povoamentos clonais é a diminuição da alta variabilidade das populações florestais. A clonagem permite a reprodução de árvores com características genéticas idênticas ou semelhantes às da árvore matriz e, com isto, a seleção de características desejáveis (Klein et al., 2000). As espécies do gênero Eucalyptus são adequadas para a clonagem, pois apresentam alta herdabilidade para diversas características, permitindo a seleção de genótipos superiores, não somente em crescimento, mas também em qualidade da madeira.

De acordo com Rojas Vergara (1989), a utilização da técnica de clonagem na área de melhoramento florestal comporta uma série de vantagens, como: ganhos genéticos mais rápidos e seguros; plantios mais uniformes, e portanto, mais facilmente manejados e explorados; e redução do problema de "dominância não compensada", que ocorre quando, na eventualidade de uma árvore ser dominada, o aumento no crescimento das árvores circunvizinhas não compensa a redução em volume da árvore dominada.

Sendo assim, a utilização de clones para a formação de florestas foi um dos avanços que possibilitaram maior produção, melhoria da qualidade e homogeneização da matéria-prima utilizada pela indústria. Porém, a adoção de técnicas de implantação e manejo visando à obtenção de povoamentos regulares e produtivos, que satisfaçam economicamente as condições de implantação e colheita, continua indispensável, quando se trata de obter plantios com fins industriais (Klein et al., 2000). 
Nota-se que o desenvolvimento de técnicas para determinar a produtividade florestal, utilizando atributos do solo, tem precedido o manejo florestal. Igualmente importante, na previsão de produtividade, é a habilidade dos reflorestadores em reconhecer e classificar sítios para especificar tipos de manejo.

\subsection{Classificação da qualidade de sítios florestais}

Com o crescente aumento da demanda por produtos florestais, torna-se cada vez mais necessário o emprego de práticas de manejo adequadas para proporcionar aumento da produtividade das florestas. Nesse sentido, a determinação da qualidade do sítio, isto é, da sua capacidade produtiva, constitui um dos primeiros e mais importantes passos para se conseguir um planejamento adequado e garantir o sucesso do empreendimento florestal (Oliveira, 1998).

As produções esperadas para as plantações florestais dependem da capacidade produtiva. Estimativas seguras podem ser obtidas somente com uma avaliação precisa do potencial de crescimento (Newberry \& Pienaar, 1978). Para o desenvolvimento de planos de manejo, é necessário verificar o potencial produtivo de cada povoamento dentro de uma unidade de manejo, de maneira que o crescimento e a produção florestal possam ser prognosticados (Alemdag, 1991).

Dentre as especificações silviculturais que influenciam as decisões para o manejo de um povoamento, a rotação florestal é, sem dúvida, aquela que gera opiniões mais contraditórias. Uma decisão correta sobre a época de corte de cada povoamento ou, até mesmo, de cada talhão exige conhecimento da taxa de crescimento, bem como a produção por unidade de área, segundo a idade, a capacidade produtiva e a densidade (Rosas, 1994).

Portanto, o conhecimento da qualidade do sítio para cada unidade do terreno a ser manejada e de sua classificação quanto à sua capacidade produtiva é um importante critério para o moderno manejo florestal (Oliveira, 1998).

A capacidade produtiva de uma área florestal é determinada em virtude da ação e interação de fatores bióticos, climáticos, edáficos e topográficos, influenciados pelas 
práticas silviculturais e de manejo florestal. Esta capacidade produtiva recebe a denominação de qualidade do sítio, também denominada de qualidade do local (Barros, 1974).

Segundo Barros (1974), a avaliação da qualidade do sítio é básica para diversas atividades da prática florestal. Deste modo, a determinação de alternativas econômicas na compra de terras, intensidade de práticas silviculturais, tais como cortes intermediários e a previsão da produção no corte final são muito facilitadas pela avaliação da capacidade produtiva do sítio.

Para estudo e compreensão dos atributos do meio, intrínsecos à qualidade do sítio, eles podem ser divididos em categorias amplas, envolvendo:

- clima (radiação solar, precipitação, temperatura e umidade relativa do ar etc.);

- topografia (face de exposição, declividade, pedoforma etc.);

- solo (textura, estrutura, regimes térmico e hídrico, minerais, nutrientes etc.);

- atributos bióticos (plantas, animais, insetos, fungos) e antrópicos.

De acordo com Spurr \& Barnes (1980), as interrelações entre esses atributos resultam em recursos diretamente disponíveis para o crescimento de árvores, como luz, calor, água, elementos químicos $\left(\mathrm{CO}_{2}, \mathrm{O}_{2}\right.$, fertilidade etc.) e mecânicos (danos causados por fogo, geada, manejo florestal etc.)

Os métodos para determinação da qualidade do sítio, ou seja, para estimar a produtividade de sítios florestais, podem ser divididos em métodos diretos e indiretos. A capacidade produtiva pode ser mensurada diretamente pelo crescimento da floresta em si, ou por meio de estimativa, a partir de atributos do local que expressam a sua produtividade (Rennie, 1963; Carmean, 1975; Gonçalves, 1990 e Oliveira, 1998).

Segundo Oliveira (1998), os métodos mais usuais para avaliar a qualidade do sítio baseiam-se no conhecimento de condições edáficas e na relação altura dominante (Hd) e idade (I) das árvores, uma vez que o crescimento em altura dominante reflete os fatores do meio. Apesar de as informações oriundas de uma base edáfica ou de alturas dominantes se destinarem a objetivos diferentes, elas podem ser usadas de forma complementar. Assim, pode-se, por exemplo, determinar a qualidade do sítio pelas características do solo e definir as unidades de manejo, e dentro de cada área avaliar a 
qualidade baseando-se na relação altura dominante e idade do povoamento, com a finalidade de se conhecer a sua capacidade produtiva, direcionada para fins de prognose da produção e de planejamento e manejo.

A qualidade do sítio, normalmente, é igualada a determinada componente mensurável da produtividade florestal (como altura total das árvores dominantes) que, em verdade, é uma expressão fisiológica dos efeitos integrados das variáveis biológicas e do meio ambiente que influenciam no crescimento até a época da medição (Ralston, 1964). Desta forma, o índice de qualidade do sítio é sempre um valor estimado. Segundo Rennie (1963) e Brum (1979), a equação mais comum e convencional para expressar esta qualidade é a relação altura-idade, denominada de índice de sítio ("site index") ou de local.

Os métodos diretos avaliam a capacidade produtiva em termos do crescimento das árvores em altura, área basal, volume, biomassa etc. (Ralston, 1964). Dentre os métodos diretos de classificação de sítio pode-se destacar o método dos Índices de Sítio Preliminar (Rennie, 1963 e Gonçalves, 1990).

O grande mérito dos métodos diretos é avaliar o crescimento das árvores, que em última instância expressa realmente a produtividade do local. Entretanto, esses métodos não permitem identificar os fatores ambientais que realmente determinam a capacidade produtiva. Normalmente foram desenvolvidos em regiões onde os sítios apresentavam maior potencial produtivo e o manejo florestal era menos intensivo, em comparação com as condições brasileiras. No Brasil, os solos geralmente têm baixa fertilidade e uma porção considerável dos nutrientes está imobilizada na biomassa, sendo a produtividade alterada a cada corte. Portanto, as classes de produtividade deveriam ser reavaliadas periodicamente e as árvores necessariamente estar presentes para efetuarem-se medições regulares (Barros et al., 1986).

Nos métodos indiretos, a produtividade do sítio é estimada indiretamente, tendo por base as características ambientais ou plantas indicadoras ocorrentes na área, entre os quais o método solo-sítio e levantamento de solo são os mais difundidos no setor florestal brasileiro (Gonçalves, 1990 e Oliveira, 1998).

Os métodos indiretos de classificação de sítio podem ser divididos em 
quantitativos, também conhecidos por análises fator-sítio ou solo-sítio, e métodos qualitativos, que envolvem a divisão de terras em unidades com características, potencial de produção e de uso uniformes (Schonau, 1987).

Segundo Hannah (1968b), o método fator-sítio busca estabelecer relações matemáticas entre o crescimento das árvores e os atributos do meio. Esse método estima a qualidade de sítio para uma dada espécie, densidade, composição e condição existente no povoamento e, a princípio, permite estimativas posteriores de produtividade, pela simples avaliação das variáveis equacionadas, mesmo que não existam árvores no local.

Entretanto, para obter um modelo realmente eficiente deve-se considerar um intervalo amplo de variação de produtividade e de condições ambientais, que permita abranger desde níveis deficitários até níveis excessivos dos atributos determinantes da produtividade dos sítios (Ralston, 1964). Portanto, os resultados dependem da seleção e da acessibilidade aos atributos adequados para a escala de investigação e deve-se ter cuidado no exercício de interpretação causal entre a produção e atributos do meio (Schonau, 1987).

O método indireto denominado de solo-sítio, baseia-se na locação de parcelas em povoamentos florestais, abrangendo uma série de sítios com diferentes capacidades produtivas, em função das variações climáticas, fisiográficas e edáficas existentes na área ou região florestal designada para o estudo (Gonçalves, 1990). Este método é válido somente para as áreas cujas diferenças edáficas afetam diretamente o crescimento das árvores, sendo mais eficiente em regiões com padrão pedogenético mais homogêneo, como os chapadões latossólicos sob cerrado (Carmo et al., 1990).

$\mathrm{Na}$ etapa seguinte, os índices de sítio estimados, a partir das árvores existentes nas parcelas demarcadas, são correlacionados com as características climáticas, fisiográficas e edáficas, avaliadas por meio do uso de regressões múltiplas. Para esse objetivo, as características do sítio não precisam ser fatores causais, mas devem ser consistentemente correlacionadas com o índice de sítio. As características comumente correlacionadas com o índice de sítio devem ser facilmente reconhecidas e mapeadas pelo silvicultor.

As equações obtidas com os estudos do tipo relação solo-sítio somente podem ser 
aplicadas em áreas cujas características ambientais assemelham-se às áreas que deram origem às equações (Gonçalves, 1990).

A interpretação biológica e, ou fisiológica dos efeitos dos fatores (ou variáveis) ambientais sobre o crescimento, muitas vezes torna-se difícil nesse sistema, e os atributos correlacionados com a produtividade não são necessariamente determinantes do crescimento das árvores (Barros et al., 1986). Por outro lado, é comum obter-se uma relação inversa entre as variáveis reconhecidamente determinantes do crescimento e produção florestal (Barros, 1974; Cardenas, 1987; Gonçalves, 1990 e Shorter, 1993).

De acordo com Hannah (1968a), dentro de um determinado estrato climático, tem sido aconselhada a utilização do método solo-sítio para avaliação da capacidade produtiva de um determinado local. Esse processo envolve relacionamento das características edáficas e topográficas com o índice de sítio. A principal vantagem do processo é que a qualidade do sítio pode ser estimada para uma espécie com determinada idade, composição ou condição existente no povoamento. Uma vez estabelecida uma equação que relacione o crescimento com algumas daquelas características, a produtividade da área pode ser estimada pela sua simples avaliação, ainda que não existam plantações da espécie.

No Brasil, podemos destacar os trabalhos de relação solo-sítio desenvolvidos por Goor (1965a e 1965b); Barros (1974); Hoogh \& Dietrich (1979); Santana (1986); Cardenas (1987); Fabres et al. (1987); Gonçalves (1990); Shorter (1993) e Braga (1997).

Nos métodos indiretos qualitativos, a predição da capacidade produtiva usualmente possui importância secundária (Schonau, 1987). O principal objetivo é delimitar áreas com potencial silvicultural e de manejo similares, ou indicar alternativas de uso para essas áreas. Conseqüentemente, esses métodos são amplamente usados em zoneamento e classificação de regiões, considerando atributos bióticos e abióticos do meio, como clima, fisiografia, características edáficas etc.

O clima é sempre o fator primário para a classificação e determinação de sítios em larga escala (Spurr \& Barnes, 1980 e Schonau, 1987). Em estudos de áreas menores, a vegetação, a fisiografia e o solo tornam-se mais importantes. Em regiões onde a vegetação nativa foi muito alterada e espécies exóticas foram introduzidas, a fisiografia e 
o solo assumem a prioridade.

A classificação de solos pode ser usada na estratificação de sítios, algumas vezes associada com outros fatores ambientais. Carmean (1975) e Tesch (1981) listam vários estudos que relacionam a qualidade do sítio com unidades de solo. Entretanto, as relações entre as classes de solo e produtividade florestal podem ser fracas, porque os critérios de avaliação química e de classificação de solos foram desenvolvidos sobre bases pedológicas e, ou agrícolas. Assim, é comum observar variação de produtividade florestal dentro de uma mesma categoria de solo ou mesmo produtividades similares entre diferentes unidades taxonômicas (Goor, 1965b; Barros, 1974; Carmean, 1975; Hoogh \& Dietrich, 1979; Fabres et al., 1987; Gonçalves, 1990; Correia, 1993 e Shorter, 1993).

As variações de produtividade entre ou dentro de unidades de solo são devidas a certas características fisiográficas e do próprio solo que são relacionadas com o crescimento das árvores, mas que não estão incluídas nas definições e atributos das unidades taxonômicas de solos (Gonçalves, 1990). O levantamento de solos pode ser útil como ponto de partida para posterior redefinição das classes de sítio, segundo a produtividade florestal. Assim, as unidades taxonômicas originais seriam subdivididas ou ampliadas, com base no crescimento da floresta (Barros et al., 1986).

Os métodos diretos e indiretos de avaliação da qualidade de sítio são de muitas formas complementares e têm como objetivo comum a classificação e a predição da capacidade produtiva da terra para fins florestais. Portanto, o mais oportuno consiste na integração desses dois métodos nos trabalhos de inventário da paisagem e classificação de sítios, onde cada sistema terá sua parcela de contribuição no todo final (Carmean, 1975).

A qualidade do sítio varia com a espécie florestal, genótipo, preparo e fertilização florestal. A suposta capacidade ótima de produção pode também ser influenciada pela variação na precipitação, compactação e erosão do solo, incidência de doenças e danos causados por insetos. A mais importante tarefa na pesquisa de sítios, no futuro próximo, é investigar como esses vários atributos influenciam o crescimento e de que modo os parâmetros que expressam essa influência podem ser incorporados nos modelos de 
crescimento para a predição da produção (Schonau, 1987).

\subsection{Inventário florestal}

As informações básicas para subsidiar o manejo e o planejamento da produção florestal são obtidas por meio do inventário florestal, que em florestas plantadas é usualmente determinado por meio de medições de um certo número de árvores que compõem as parcelas em campo amostradas (Nakajima et al., 2000).

Segundo Nakajima et al. (2000), a determinação do processo de amostragem a aplicar depende de um reconhecimento prévio da área de estudo. Um dos métodos mais utilizados é o da parcela circular (CP), um método padrão com área circular e raio fixo. Neste método, o número de árvores dominantes e codominantes, a serem medidas, determina o raio de busca destas árvores a partir do centro da área abrangida pela parcela. Obtida a média aritmética dos dados de altura coletados para as árvores dominantes e codominantes dentro do círculo pode-se determinar o índice de sítio para a parcela.

De acordo com Carmean (1968), esse índice é o mais utilizado para determinar a produtividade de uma área florestal, sendo uma expressão da qualidade do sítio baseada na altura das árvores dominantes e codominantes em uma determinada idade índice. $\mathrm{O}$ índice de sítio tem sido apontado por muitos pesquisadores como o mais adequado para a estimativa da produtividade do sítio, por ser de fácil obtenção e não ser influenciado pela densidade de árvores do povoamento (Gonçalves, 1990).

A altura das árvores dominantes e codominantes em povoamentos equiâneos é utilizada por ser uma característica que sofre menor influência da densidade do povoamento, ou seja, teoricamente elas são insentas de competição, exceto quando ocorre desbaste, por isso é uma medida considerada como padrão em termos comparativos com os outros indicadores da qualidade do sítio (Davis, 1966; Spurr \& Barnes, 1980 e Oliveira, 1998). Segundo Davis (1966) e Brum (1979), o crescimento em altura das árvores dominantes e codominantes é muito sensível à diferença no sítio, fortemente correlacionado com o crescimento volumétrico e fracamente correlacionado com a densidade e a composição de espécies. 
O crescimento das árvores dominantes sofre a ação simultânea de muitos atributos que agem de forma interativa. Assim, ao se medir a altura das árvores dominantes, automaticamente estarão sendo medidos os efeitos desses atributos, pois a altura média das árvores dominantes não á afetada por competição quando o espaçamento não é muito denso (Campos et al., 1991).

Portanto, o índice de sítio pode ser utilizado como um índice da qualidade do sítio em povoamentos (Spurr, 1964), sendo estreitamente relacionado com a capacidade de um dado local em produzir madeira (Rennie, 1963).

O principal motivo que faz com que se despreze a altura média e se adote a altura dominante é devido à grande influência do desbaste, elevando, automaticamente, o valor da altura média com o corte das árvores pequenas no povoamento. Por outro lado, a altura dominante não sofre influências do desbaste, a não ser que se aplique desbaste por alto, o que altera o estrato superior (Schneider, 1993).

Para Husch et al. (1982), Finger (1992) e Scolforo (1997), a relação hipsométrica sofre influência do sítio, idade, densidade, tamanho da copa, espécie e da posição sociológica em que a árvore se encontra no povoamento e diferindo, desta maneira, para árvores de classes sociológicas diferentes. Em se tratando da relação hipsométrica, há que se considerar que em povoamentos cujos sítios são bem definidos, bem formados e conduzidos, espera-se uma correlação forte entre as variáveis altura e diâmetro, devido a maior homogeneidade na população considerada; e em povoamentos mal formados, mal conduzidos ou em sítios não muito bem definidos há que se esperar uma fraca correlação, devido a maior heterogeneidade da população considerada.

Segundo Girardin \& Broquen (1995), os povoamentos que devem ser eleitos, a fim de que se possa utilizar a altura dominante como indicadora das condições de sítio, devem atender os seguintes pré-requisitos: a população a ser amostrada não deve se encontrar no estado juvenil de crescimento, pois nesse estágio o crescimento é muito variável e pode ser afetado por outros atributos que não a qualidade do sítio; nessa fase não tem sentido a utilização do volume como variável importante; as densidades não devem ser extremas, entre 900 e 2500 árvores por hectare, de forma que não afetem a altura dominante; práticas silviculturais que tenham removido árvores dominantes não 
devem ter sido realizadas; o estado sanitário deve ser bom e as árvores dominantes não podem ter sofrido danos severos.

De acordo com Barros et al. (1986), o poder de previsão de produtividade do índice de sítio é bastante baixo, devido ser um método desenvolvido e aplicado inicialmente em regiões onde os sítios apresentavam maior potencial para a manutenção da produtividade; onde o manejo florestal não é tão intensivo quanto no Brasil; onde os solos são de baixa fertilidade natural e onde uma porção considerável dos nutrientes está imobilizada na biomassa.

Avery \& Burkhart apud Scolforo \& Machado (1988) afirmaram que o índice de sítio não é uma constante, mudando periodicamente devido a variações ambientais e climáticas, sendo que o seu valor para uma determinada espécie não pode ser utilizado como índ ice para diferentes espécies no mesmo sítio.

No entanto, mesmo com algumas limitações, o índice de sítio é o método mais universalmente utilizado para definir a potencialidade dos sítios florestais, e assim o será, até que métodos que conjuguem a soma de fitores ambientais possam ser traduzidos de forma numérica acessível aos usuários do setor (Cunha Neto et al., 1996).

\subsection{Fatores ambientais}

Os efeitos dos fatores ambientais sobre o crescimento dos povoamentos florestais agem interrelacionados e, raramente, podem ser analisados isoladamente. As características fisiográficas do ambiente são mais determinantes da produtividade do que as características de fertilidade do solo, ou seja, quando uma unidade amostral ocupa uma posição adequada em termos de exposição, posição na toposequência, declividade etc., a fertilidade do solo tem efeito pouco expressivo (Braga, 1997). Entretanto, ao sair daquelas situações fisiográficas ideais, a fertilidade do solo passa a ser importante na definição da capacidade produtiva. Sob condição fisiográfica ótima, a exigência quanto à fertilidade do solo é mínima; mas, à medida que a condição fisiográfica se afasta do ideal, a exigência de fertilidade aumenta. 


\subsubsection{Características fisiográficas}

Sob condição climática regional uniforme, freqüentemente é possível relacionar a produtividade florestal com variáveis fisiográficas. O efeito das variações de relevo sobre o microclima e o regime de umidade do solo pode ser caracterizado indiretamente pela altitude, exposição, declividade, pedoforma e posição na toposequência (Ralston, 1964; Carmean, 1975 e Braga, 1997).

\subsubsection{Face de exposição}

A face de exposição é um elemento da fisiografia que tem sido relatado por diversos pesquisadores (Myers \& Deusen, 1960; Castaños, 1962; Hannah, 1968a e 1971; Graney \& Ferguson, 1971 e 1972), afetando a produtividade por sua influência na evapotranspiração.

Segundo Lee \& Sypolt (1974) e Lee (1978), as diferenças de produtividade entre as exposições se devem ao microclima da encosta, relacionado com a quantidade de energia solar incidente e, conseqüentemente, com o regime térmico, afetando diretamente os processos fisiológicos básicos das árvores. Nesse caso, uma carga energética excessiva e temperaturas supra-ótimas podem, por exemplo, povocar estresse hídrico e redução da fotossíntese líquida.

A exposição da encosta, e conseqüentemente, a condição microclimática, também podem afetar o desenvolvimento do perfil de solo (espessura de horizontes, textura etc.), exercendo influência sobre a capacidade produtiva (Carmean, 1965 e 1975 e Spurr \& Barnes, 1980).

De acordo com Tubelis \& Nascimento (1983), para as latitudes próximas a $20^{\circ} \mathrm{S}$, a orientação sul tem o efeito de diminuir a radiação solar ao longo de todo o ano, em relação à superfície plana, sendo o efeito mais pronunciado no inverno e com o aumento da inclinação do terreno. As orientações norte recebem radiação passando por um mínimo no solstício de verão e por um máximo no solstício de inverno. As orientações leste e oeste afetam menos o recebimento de radiação solar que as orientações norte e sul, 
notadamente para inclinações menores que $20^{\circ}$ (36\% de declividade).

Braga (1997) observou na região do Mar de Morros, no Médio Rio Doce (MG), considerando a radiação solar incidente ao longo dos meses e estações do ano, que o mês de outubro é o mais importante na definição de qualidade do sítio. Os sítios de melhor qualidade recebem maior quantidade de radiação solar em outubro do que os sítios de pior qualidade. As variáveis pedoforma, altitude e posição relativa na toposequência mostraram-se também cruciais na definição das classes de qualidade do sítio.

\subsubsection{Declividade}

Fatores como declividade e posição topográfica influenciam a produtividade do eucalipto de maneira indireta, por influenciarem nas características físicas do solo, como permeabilidade, porosidade, espessura (Teixeira, 1987), taxa de infiltração de água e erosão (Barros, 1974).

O fator declividade é comumente relatado na literatura como importante na definição da produtividade florestal. Entretanto, seu efeito no crescimento das árvores é indireto e mais pronunciado em rampas mais inclinadas. Dentre os fatores diretos associados à declividade do terreno inclui-se o microclima do ar e do solo (regimes térmico e hídrico, comprimento do dia etc.), envolvendo o suprimento, a disponibilidade e o movimento superficial e subsuperficial de água no solo, a quantidade de radiação solar recebida etc. (Coile, 1952; Carmean, 1975; Spurr \& Barnes, 1980 e Kozlowski et al., 1991). A relação normalmente é inversa, isto é, quanto maior a declividade, menor é o crescimento das árvores (Trimble Jr \& Weitzman, 1956; Ralston, 1964; Carmean, 1967; Hills, 1976; Grey, 1979 e 1985; Meeuwig \& Cooper, 1981; Meiners et al., 1984; Pregitzer \& Barnes, 1984; Harding et al., 1985; Fabres et al., 1987; Hix, 1988; Brais \& Camiré, 1992 e Morris \& Parker, 1992).

O crescimento varia em função do relevo e, de modo geral, o aumento da declividade reduz o crescimento (Zahner, 1958 e 1962; Myers \& Deusen, 1960 e Braga, 1997).

Fabres et al. (1987) relatam que, na região do Mar de Morros (MG), as árvores 
localizadas nas rampas mais íngremes apresentavam fortes sintomas de deficiência nutricional.

\subsubsection{Pedoforma}

A pedoforma é um dos atributos identificadores do pedoclima (Carmo et al., 1990). As pedoformas côncavas favorecem a concentração de água e nutrientes no sistema, enquanto as convexas atuam de maneira inversa (Graney \& Ferguson, 1971 e 1972; Carmean, 1975; Spurr \& Barnes, 1980 e Resende et al., 1997). Desta forma, as pedoformas côncavas comumente são mais produtivas do que as convexas (Carmean, 1967 e 1975; Hannah, 1968a; Spurr \& Barnes, 1980; Santana, 1986; Callaway et al., 1987; Fabres et al., 1987; Teixeira, 1987 e Brais \& Camiré, 1992).

Segundo Carmo et al. (1990), em campo, verifica-se maior crescimento do eucalipto nos fundos de grota (concavidade) em relação às áreas convexas aos topos de morro. No trabalho de Santana (1986), com Corymbia citriodora, as encostas côncavas mostraram-se mais férteis. Em estudo na região do Mar de Morros (MG), Fabres et al. (1987) relatam que as pedoformas côncavas são as mais férteis, e que os teores foliares dos nutrientes diminuíram no sentido encosta côncava, meia encosta, encosta convexa e topo.

Mudanças na elevação e forma da superfície causam profundas modificações no regime hídrico do solo, principalmente em áreas com teor de umidade deficiente. Também o teor de certos nutrientes varia segundo a forma do terreno, de acordo com o que afirma Rezende (1971), possivelmente em consequiência da ação da erosão e lixiviação. Normalmente o crescimento decresce quando a forma do terreno passa de côncavo-linear-convexa (Hannah, 1968a; Graney \& Ferguson, 1971 e 1972; Bowersox \& Ward, 1972). 


\subsubsection{Profundidade do solo}

O estudo das características de perfis do solo, incluindo o substrato, fornece meios para avaliar a variação na produtividade do sítio dentro de um estrato climático e topográfico. Desvios substanciais na qualidade do sítio, para uma classe fisiográfica homogênea, estão freqüentemente associados a diferenças no suprimento de água, em nutriente e aeração do solo (Pawluk, 1961 e Ralston, 1964).

A profundidade do "solum" e outras características do perfil do solo (textura, estrutura etc.) podem variar significativamente ao longo da toposeqüência, notadamente em terrenos mais inclinados (Carmean, 1967 e 1975 e Spurr \& Barnes, 1980). O "solum" tende a ser menos profundo nas partes mais íngremes e medianas da encosta e nos topos de morro (cristas e cumes) (Resende, 1985).

Fabres et al. (1987) relatam que a redução da espessura do "solum" reduz a produtividade da floresta, devido à restrição da disponibilidade de água e nutrientes no solo, com as árvores exibindo sintomas de deficiência nutricional, concordando com Farnsworth \& Leaf (1963) e Linnartz (1963).

A profundidade efetiva é uma característica do perfil do solo de grande influência no suprimento de água e no livre crescimento do sistema radicular (Gonçalves, 1990).

No trabalho de Hoogh \& Dietrich (1979), os solos profundos, bem drenados, demonstraram ser menos indicados para o crescimento das araucárias, do que os solos rasos, concordando com Goor (1965a).

De acordo com Nambiar (1984) e Sands \& Mulligan (1990), as plantas podem alocar relativamente mais assimilados para as raízes do que para a parte aérea, quando há presença de camada de impedimento, principalmente quando a água do solo e nutrientes são limitantes. Com o maior desenvolvimento de suas raízes, principalmente as pivotantes, a planta pode atingir reservas hídricas localizadas em horizontes mais profundos, facilitando a extração de água a maiores profundidades do solo. 


\subsubsection{Altitude}

A altitude é outro fator de ação indireta sobre a produtividade florestal, atuando sobre fatores de ação direta na planta, como abaixamento de temperatura, regime de umidade do ar e do solo (Spurr \& Barnes, 1980). Hannah (1968b) ressalta que a qualidade do sítio aumenta com a distância até o topo, em virtude da ação gravitacional sobre a água e o fluxo subsuperficial provindo das partes mais altas. O movimento subsuperficial é uma importante fonte de umidade e, por isto, influencia a distribuição das raízes em áreas montanhosas, com formação rochosa impermeável, próxima à superfície. Em encostas extensas, o movimento é de particular importância, visto que as raízes tendem a ser uniformemente distribuídas a grandes profundidades, em comparação com solos com pequena declividade, que recebem apreciável quantidade de água, diretamente na superfície, durante a maior parte do ano (Coile, 1952).

Fabres et al. (1987) observaram o afloramento de cascalheiras nas partes mais elevadas (topos de morro), limitando a profundidade efetiva do perfil. No trabalho de Braga (1997), as posições mais produtivas na toposequência foram aquelas abaixo da meia encosta, provavelmente relacionadas com melhores condições de umidade e fertilidade de solo (Coile, 1952; Carmean, 1975; Radloff \& Betters, 1978; Spurr \& Barnes, 1980; Meiners et al., 1984; Pregitzer \& Barnes, 1984; Santana, 1986; Fabres et al., 1987; Teixeira, 1987; Hix, 1988; Archambault et al., 1990 e Brais \& Camiré, 1992).

Os resultados do trabalho de Teixeira (1987), em povoamentos de Eucalyptus spp, demonstraram que os solos do topo apresentavam limitação de nutrientes, principalmente de cálcio, e os solos das baixadas apresentavam nível de fertilidade mais elevado, com maior disponibilidade de fósforo e magnésio, mas sem que isto se traduzisse em maior produtividade, visto que as características físicas destes solos, tais como profundidade, permeabilidade e porosidade, mostraram-se menos adequadas para o crescimento das plantas do que as do topo.

No trabalho de Torrado (1989), a porcentagem de argila do horizonte A decresceu do topo para a baixada, ou seja, à medida que aumentou a dstância do topo, o teor de argila diminuiu. $\mathrm{O}$ autor relata que as partículas grossas deslocam-se das posições 
superiores e depositam-se nas posições de sopé e meia encosta inferior.

\subsubsection{Deficiência hídrica do solo}

De acordo com Hanna et al. (1982), a disponibilidade de água é influenciada pela posição topográfica do local amostrado na paisagem. A água é importante, tanto para o desenvolvimento das plantas como para a formação do solo. O local numa paisagem interfere neste processo, devido à maior ou à menor quantidade de água, o que provavelmente aumenta a variabilidade do mesmo. Ciha (1984) encontrou que a posição de um ponto amostrado na paisagem teve forte influência sobre o rendimento da cultura de trigo. $\mathrm{O}$ autor relacionou este fato aos atributos do solo, como espessura da camada superficial, e a diferentes níveis de disponibilidade de água ao longo do relevo.

O estudo de Garcia Y Garcia (1997), concluí que a retenção de água no solo foi influenciada pelo relevo e pela distribuição espacial da granulometria, visto que as áreas mais altas apresentaram maior conteúdo de argila no solo, que por sua vez correspondiam as áreas com menor potencial mátrico. As áreas mais baixas apresentaram maior conteúdo de areia no solo, que por sua vez correspondiam as áreas com maior potencial mátrico. $\mathrm{O}$ autor também relata tendência de maior contéudo de umidade no solo nas áreas com maior contéudo de argila.

Segundo Levitt (1980), plantas que fecham precocemente os estômatos são consideradas preventivas, enquanto espécies que mantêm os estômatos abertos quando submetidas a déficites hídricos severos são tidas como tolerantes à seca. Diante disto, Façanha (1983) considera E. grandis uma espécie que se previne contra a seca, visto que seus estômatos se fecham antes que algum murchamento visível ocorra.

De acordo com Gonçalves (1990), freqüentemente a disponibilidade de água no solo é o fator que mais determina o crescimento das árvores. A existência de camadas de impedimento físico à penetração mais profunda das raízes, drenagem interna e capacidade de armazenamento de água e de oxigênio deficiente, aumentam os riscos de estresse hídrico das plantas nos períodos de estiagem (Gatto, 2000). Como resultado, a 
cultura explorada não encontra condições apropriadas no solo para um bom desenvolvimento, refletindo negativamente na produtividade final (Beltrame et al., 1981).

Por outro lado, plantas em solos com maior disponibilidade de água, ar e nutrientes, distribuem melhor seu sistema radicular no perfil do solo e estão mais preparadas para enfrentar estresse hídrico (Gatto, 2000). Essas plantas, dentro de certos limites, alocam menor quantidade de carbono no sistema radicular, em benefício da parte aérea, refletindo, conseqüentemente, no aumento da biomassa (Reis \& Barros, 1990).

A deficiência hídrica do solo pode afetar o crescimento em altura e em diâmetro, diretamente, reduzindo a expansão celular e a formação da parede celular e, indiretamente, reduzindo a disponibilidade de carboidratos ou influenciando a produção de reguladores de crescimento (Oliva et al., 1989).

Segundo Pereira (1979), o déficite hídrico do solo afeta o crescimento em altura das árvores, reduzindo o alongamento do caule e o número e tamanho das folhas, como também o crescimento cambial.

A disponibilidade de água afeta o crescimento das plantas, por controlar a abertura dos estômatos e, conseqüentemente, a produção de matéria seca (Oliva et al., 1989 e Gholz et al., 1990). Um decréscimo de água no solo diminui o potencial de água na folha e sua condutância estomática, promovendo o fechamento dos estômatos. Esse fechamento bloqueia o fluxo de $\mathrm{CO}_{2}$ para as folhas, afetando o acúmulo de fotoassimilados, o que implica em redução da produtividade.

O maior fechamento estomático influencia negativamente na produção e no acúmulo de assimilados. O fechamento estomático, normalmente observado em plantas que previnem a desidratação, apresenta vários efeitos colaterais que reduzem o crescimento das plantas. Os principais efeitos são: decréscimo na produção de fotoassimilados e aumento na atividade de enzimas oxidativas, resultado do aumento da temperatura da planta, que leva ao aumento da respiração, gasto de fotoassimilados e, conseqüentemente, redução do crescimento (Larcher, 1975 e Kozlowski, 1982).

Sob baixa disponibilidade de água nos solos, os potenciais hídricos são muito baixos, afetando vários processos metabólicos nas plantas, provocando fechamento parcial ou total dos estômatos e limitando a perda de água e fixação de $\mathrm{CO}_{2}$ (Nobel, 
1974). Dessa forma, os mecanismos que previnem a tensão das plantas, quase sempre são incompatíveis com a produção florestal (Teixeira, 1978). A baixa disponibilidade de água também afeta o "status" nutricional das plantas, uma vez que a água constitui um veículo pelo qual os nutrientes chegam às raízes ou são translocados (Novais et al.,1990). Como exemplo temos o boro, que é um elemento que apresenta reduzida mobilidade no solo quando sob deficiência hídrica, favorecendo, portanto, o desenvolvimento da seca de ponteiros nas plantas, nessas condições (Barros et al., 1990).

Façanha (1983), estudando E. grandis, E. cloeziana e E. camaldulensis, concluiu que déficites hídricos sucessivos de intensidade moderada e severa provocaram um aumento da resistência difusa ao vapor d'água, com uma conseqüente diminuição da transpiração e da fotossíntese.

Por meio da análise dos resultados alcançados por Gomes (1994), na região de Três Marias (MG), foi verificado que E. camaldulensis, entre 14 e 26 anos, apresentou redução em crescimento durante o período de precipitação mais baixa, sendo que essa redução foi mais drástica para o crescimento em diâmetro.

No trabalho de Awe et al. (1976), seis ecótipos de E. camaldulensis mostraram diferenças no crescimento em altura e em diâmetro, quando submetidos a déficite hídrico. Os resultados do trabalho de Pereira \& Kozlowski (1976), demonstram que o crescimento em altura de E. camaldulensis e de E. globulus também decresceu com o déficite hídrico. Já Rook et al. (1976) observaram que o defícite hídrico reduziu o crescimento em diâmetro do caule e da raiz em Pinus radiata.

Segundo Sands \& Mulligan (1990), a elevada disponibilidade hídrica no solo torna a fertilização mais efetiva, com maior eficiência na absorção dos nutrientes, visto que estes se movem da solução do solo até a superfície da raiz por fluxo de massa e difusão.

\subsubsection{Características físicas do solo}

A capacidade de armazenamento de água pelo solo e sua disponibilidade para as plantas são determinadas, de certa forma, pelas características físicas do solo, como 
textura, estrutura e profundidade (Amaral, 2000).

Admite-se que o eucalipto é uma essência florestal mais exigente no que se refere aos atributos físicos do solo, particularmente quanto à profundidade e à permeabilidade (Barros, 1974). A estas, Amaral (2000) acrescenta textura e estrutura do solo, que em conjunto interferem na capacidade de armazenamento de água pelo solo e, conseqüientemente, no crescimento e na produtividade. O regime hídrico do solo é um fator essencial ao crescimento da maioria das espécies de eucalipto (Alvarenga, 1961; Metro, 1966; Melo, 1994 e Leite, 1996).

Vários fatores influenciam na retenção hídrica de um solo. No entanto, a retenção de água depende primeiramente da textura do solo e da estrutura ou arranjo das partículas (Fietz, 1998). A capacidade de armazenamento de água geralmente está relacionada com a composição granulométrica do solo, aumentando à medida que a textura vai diminuindo. No entanto, em solos de regiões tropicais e subtropicais, como os latossolos, muitas vezes a capacidade de armazenamento é mais influenciada pela estrutura e composição mineralógica da fração argila do que a granulometria (Fietz, 1998).

A grande maioria dos estudos de relação solo-sítio evidencia que os atributos físicos dos solos relacionam-se com a produtividade do sítio, com maior frequiência que os atributos químicos, principalmente aqueles relacionados com a capacidade de retenção e armazenamento de umidade do solo (Gonçalves, 1990).

Dentre as características físicas, a profundidade e a textura do solo têm sido mencionadas como as de maior significância na determinação da produtividade do sítio. A espessura da camada superficial e total do solo é geralmente correlacionada com o índice de sítio (Doolittle, 1957; Zahner, 1958; Myers \& Deusen, 1960; Della-Bianca \& Olson, 1961; Jackson, 1962; Castaños, 1962; Phillips \& Markley, 1963; Hannah, 1968a; Bowersox \& Ward, 1972 e Sprackling, 1973). Elas são de particular importância para os solos rasos ou solos que possuem camadas adensadas, as quais têm efeito sobre o desenvolvimento do sistema radicular, bem como sobre o regime hídrico do solo.

A influência da textura na produtividade tem sido relatada mais como um fator determinante da disponibilidade de água para as plantas. Assim, o aumento do teor de silte e argila (frações texturais finas), até determinados valores nos horizontes 
superfíciais e subsuperfíciais, geralmente está associado, diretamente, com um aumento no crescimento (Doolittle, 1957; Zahner, 1958; Phillips \& Markley, 1963; Bowersox \& Ward, 1972 e Gonçalves, 1990) embora correlações inversas sejam citadas em várias ocasiões (Jackson, 1962; Hannah, 1968a; Broadfoot, 1969 e Hannah, 1971), mormente em locais onde a aeração se torna deficiente. Neste caso, o aumento do teor de areia favorece o crescimento (Della-Bianca \& Olson, 1961).

O regime hídrico do solo pode ser também modificado por variações na quantidade de cascalho e pedregulhos. Sob algumas condições, moderadas quantidades de partículas grosseiras podem beneficiar o crescimento, visto favorecer a fácil penetração das águas de chuvas pouco intensas e, assim, reduzir a perda por evaporação. Contudo, quando em grandes quantidades, isto pode ter efeito adverso, em virtude da redução no volume efetivo do solo (Strothmann, 1960), bem como por afetar a capacidade de armazenamento e retenção de umidade do solo (Hannah, 1968a; Graney \& Ferguson, 1971 e Correia, 1993 e 1996).

No trabalho de Schonau \& Aldworth (1991), com Acacia mearnsii no leste da África do Sul, foi encontrada relação positiva entre teor de areia grossa e índice de sítio. Concluíram que a areia grossa favoreceu a friabilidade do subsolo, facilitando a penetração das raízes. Shorter (1993) relata que a areia fina, grossa e total, ao contrário da argila, tiveram efeito positivo significativo a $5 \%$ sobre o crescimento de clones de Eucalyptus grandis no sul da Bahia. $\mathrm{O}$ autor concluiu que a relação negativa entre argila e crescimento deve-se a maior dificuldade de aeração do solo e a resistência do solo a penetração do sistema radicular.

Santana (1986) concluiu que E. saligna mostrou-se uma espécie pouco exigente em nutrientes, parecendo ser mais dependente de boas características físicas do solo que permitam maior desenvolvimento do sistema radicular e retenção de água. O autor relata que solos muito argilosos ou muito arenosos foram desfavoráveis ao crescimento de $E$. saligna, os primeiros por dificuldade de drenagem e os outros por sua elevada taxa de infiltração e baixa retenção de água, ficando a água fora do alcance de grande parte do sistema radicular. 
No trabalho de Shorter (1993), o teor baixo de silte apresentou relação negativa com o crescimento das plantas. A principal causa das diferenças de produtividade observadas entre os locais foi a deficiência hídrica, aliada ou não à resistência à penetração do solo pelas raízes, problema também relatado por Goor (1965a).

Os resultados obtidos por Grespan (1997), indicam que maiores teores de areias fina e grossa em subsuperfície mostraram efeito benéfico sobre o crescimento do eucalipto, enquanto para o teor de argila ocorreu o oposto. A fração areia pode estar reduzindo o grau de empacoramento, "quebrando" um pouco a orientação direcionada das caulinitas (camada subsuperficial caulinítica e geneticamente adensada) e favorecendo o crescimento de raízes. A fração areia fina também está envolvida no processo de retenção de água no solo.

Segundo Barnes \& Ralston (1955), Gonçalves (1988) e Gonçalves (1990), as frações texturais finas (silte e argila) assumem papéis fundamentais na capacidade de retenção de umidade e nutrientes, particularmente nos solos de textura arenosa. Entretanto para Jackson (1962), Ralston (1964), Hannah (1968b) e Gonçalves (1990), quando os teores dessas frações se elevam consideravelmente, verifica-se um comportamento inverso com relação ao crescimento das árvores, atribuído ao comportamento do sistema de aeração da atmosfera edáfica. Ralston (1964) relata que o crescimento das árvores aumenta com a elevação dos teores de silte e argila, devido a um suprimento mais favorável de água e nutrientes, até um ponto em que o acréscimo de partículas finas compromete a aeração do solo.

A relação silte/argila é um dos parâmetros que permite avaliar o grau de intemperismo do solo, podendo-se também fazer inferências a respeito dos seus níveis de fertilidade, sendo os menos intemperizados os com maior potencial de reposição de nutrientes (Santana,1986).

No trabalho de Gonçalves (1987) a argila apresentou associação positiva com a produtividade de E. grandis.

Segundo Baruqui (1983), o maior grau de floculação da argila implica em maior estruturação e estabilidade dos agregados, refletindo em maior resistência do solo à erosão. A maior floculação implica em boas condições de retenção de água, drenagem 
interna, aeração e permeabilidade, propiciando melhor penetração e desenvolvimento do sistema radicular e infiltração de água no solo. $\mathrm{O}$ mesmo pode ser dito para a relação silte/argila, muito importante na determinação das características e atributos físicos e químicos do solo, assim como na retenção e disponibilidade de nutrientes no solo (Brady, 1989). Braga (1997) coloca a floculação de argila e relação silte/argila entre as 8 variáveis ambientais determinantes da capacidade produtiva dos sítios estudados por ele, sendo o grau de floculação na camada de 0-20 cm maior nos sítios de melhor qualidade.

\subsubsection{Características químicas do solo}

Nos estudos de produtividade local, o nível de fertilidade do solo tem sido pouco mencionado como fator limitante para o crescimento das árvores, em comparação com outros atributos do solo (Barros, 1974).

Alguns estudos (Thonson \& Mccomb, 1962; Goor, 1965/66; Goor, 1965b; Goor \& Nascimento, 1969; La Bastide \& Goor, 1970; Bowersox \& Ward, 1972 e Grespan, 1997) têm mostrado que o teor de bases trocáveis é um dos principais atributos limitantes da fertilidade do solo para o crescimento. Braga (1997) observou que o equilíbrio ideal entre o cálcio e a soma de bases trocáveis, na profundidade de 0 a $20 \mathrm{~cm}$, situourse em <0,3. No trabalho de Grespan (1997), o teor de bases trocáveis dos solos esteve relacionado com o teor de matéria orgânica, sendo este processo mais intenso na camada superficial do que na subsuperficial.

Hoogh \& Dietrich (1979) e Braga et al. (1995) verificaram a importância da relação cálcio/magnésio no solo para o crescimento do E. grandis e Goor (1965a e 1965/66) para Pinus elliotti e Araucaria angustifolia. A importância do nutriente cálcio, nas condições da região do Mar de Morros, já havia sido reportada por Santana (1986), Teixeira (1987) e Fabres et al. (1987).

Os resultados atingidos por Gatto (2000) permitiram concluir que os baixos teores de potássio, cálcio e magnésio no solo limitaram o crescimento (CAP e altura) de uma floresta com E. grandis, com 38 meses de idade, em uma área de reforma pertencente a CENIBRA S/A, localizada no município de Santa Bárbara (MG). 
No Brasil, Haag et al. (1963), analisando E. urophylla e E. grandis com 2 anos de idade, no cerrado, concluíram que essas duas espécies são mais exigentes em $\mathrm{Ca}, \mathrm{N}$ e $\mathrm{K}$ do que em $\mathrm{Mg}$ e $\mathrm{P}$, para o seu crescimento.

Para Sutclifee (1980), o potássio desempenha importante função no mecanismo de movimento estomático, afetando a perda de água pela planta e, conseqüentemente, o seu "status" hídrico. De acordo com Santana (1986), o baixo teor de potássio disponível no solo pode limitar a produtividade do eucalipto.

Costa \& Carmo (1985) relatam que, em virtude da baixa capacidade de absorver íons dos solos de textura média ou arenosa, os nutrientes podem ser perdidos com facilidade do sistema. As baixadas arenosas, tanto por seus reduzidos teores quanto pela sua classe textural, são os sítios mais propensos a apresentar problemas de deficiência em potássio. A textura do solo é importante fator na disponibilidade de potássio. Os solos argilosos são capazes de manter a concentração de potássio em solução a um nível quase constante durante muito tempo. Na solução do solo arenoso, esta concentração sofre redução com maior rapidez porque, em virtude de sua baixa CTC, a maior parte do potássio permanece em solução, sendo prontamente absorvido pelas raízes ou perdido por lixiviação (Prezotti, 1985).

Os resultados obtidos com o trabalho realizado por Amaral (2000) com E. grandis, indicam que a restrição ao crescimento da floresta parece condicionada aos baixos teores de bases que os solos apresentam, maior umidade do local, características físicas do solo (maior profundidade efetiva e teor de silte). $\mathrm{O}$ autor concluiu que o cálcio e o magnésio foram os nutrientes que apresentaram maior restrição ao crescimento da floresta.

Dentre os atributos químicos do solo, o pH e o teor de matéria orgânica são os que têm sido estudados com maior frequiência, mostrando correlações positivas com o crescimento da maioria das espécies (Della-Bianca \& Olson, 1961; Thonson \& Mccomb, 1962; Dement \& Stone, 1968; Broadfoot, 1969 e Gonçalves, 1990). Outros trabalhos relatam a ocorrência de correlação negativa entre pH e crescimento (Juo \& Lal, 1977; Ulrich et al., 1980; Billet et al., 1988 e Jaiyeoba, 1995).

A literatura relata a ocorrência de correlações positivas entre crescimento do 
eucalipto, pH e teor de matéria orgânica do solo (Barros, 1974 e Correia, 1993). Vários trabalhos têm evidenciado a relação positiva da matéria orgânica com a produtividade de diferentes espécies, seja como fornecedora de nutrientes seja na melhoria das condições físicas dos solos (Barros, 1974 e Silva Júnior, 1984). No estudo de Grespan (1997), verificoutse correlação positiva entre o teor de matéria orgânica e crescimento do eucalipto ( $\mathrm{r}=0,729$ na superfície e 0,642 na subsuperfície do solo).

Além do fornecimento de nutrientes e redução do efeito nocivo do alumínio, a matéria orgânica tem elevada importância na dinâmica da água no solo, pela sua alta capacidade de absorção da umidade, assim como também concorre para melhorar as condições físicas dos solos, principalmente atuando na redução da densidade do solo, no aumento da aeração e na melhoria das condições de estruturação (Santana,1986).

Segundo Grespan (1997), em solos com baixa capacidade de troca de cátions, o aumento dos teores de matéria orgânica pode contribuir aumentando o número de cargas pH-dependentes e, conseqüentemente, da capacidade de troca de cátions, diminuindo a atividade de $\mathrm{Al}^{3+}$ e liberando nutrientes pela reciclagem $\mathrm{A}$ redução do teor de matéria orgânica traz, entre outras consequiências, a redução da CTC do solo, aumentando a perda de água e de nutrientes (Santana,1986). Para Santana (1986), a matéria orgânica pode ser importante reservatório de nutrientes no solo, podendo também reduzir o efeito negativo de altas concentrações de alumínio, pela formação de quelatos, tendo, portanto, elevada importância em solos com baixos teores de bases e elevada saturação de alumínio, condição comum em grande parte dos solos utilizados para o reflorestamento.

A hipótese de que o Al trocável em baixas concentrações pode favorecer o crescimento em espécies tolerantes foi verificada por Bueno (1971), mas ressalta que o efeito da toxidade foi verificado em concentrações superiores a $15 \mathrm{mmolc}^{-3}$.

Foy (1984) verificou que em valores de $\mathrm{pH}$ menores que 5,5, o antagonismo entre $\mathrm{Al}$ e Ca é provavelmente o fator mais limitante na absorção do cálcio e a toxidade de alumínio pode se manifestar como uma deficiência de cálcio induzida, estabelecendo um colapso nos pontos de crescimento ou nos pecíolos, em conseqüência de uma redução na absorção e na translocação de cálcio na planta (Marschner, 1986).

A fitotoxidez de alumínio pode ser atribuída diretamente a uma deficiência de 
fósforo induzida por este íon, devido a uma reação de precipitações de fosfato de alumínio, tanto na solução externa às raízes como no espaço livre aparente, reduzindo sua absorção pelas raízes e o seu subseqüente transporte para a parte aérea (Malavolta, 1980; Foy, 1988 e Braccini et al., 1998). O alumínio pode causar fitotoxidez, principalmente em solos ácidos, afetando o crescimento do sistema radicular, o que ocasiona sérios prejuízos no uso da água e nutrientes pelas plantas (Fanquim \& Vale, 1991).

Liani (1966) estudando a deficiência de nutrientes minerais e a absorção de fósforo por mudas de E. trabuttii, constatou que a máxima absorção de ${ }^{32} \mathrm{P}$ ocorreu em plantas inicialmente deficientes em fósforo, seguidas por aquelas carentes em potássio. $\mathrm{O}$ nitrogênio foi o elemento mais importante para o crescimento das plantas. Observou que a presença de boro, zinco, manganês, cobre e matéria orgânica foi indispensável ao desenvolvimento normal das plantas.

Os resultados do trabalho de Bellote (1979), analisando aspectos das exigências minerais de E. grandis, demostram que o manganês é o micronutriente mais extraído pela planta. Brum (1979) encontrou correlação significante e positiva entre a altura dominante de Pinus elliotti e o teor de manganês no solo.

Segundo Fanquim \& Vale (1991), o Mn é um elemento essencial, sendo o segundo micronutriente mais exigido pelas plantas, desempenhando importantes funções no metabolismo tais como, cofator de enzimas transferidoras de grupos e atrator de enzimas de oxirredução. Também participa da liberação fotoquímica do $\mathrm{O}_{2}$ no processo fotossíntetico.

A disponibilidade do Mn é bastante dependente do $\mathrm{pH}$; sob condições de solo ácido a disponibilidade é alta, devido à maior solubilidade dos compostos que o contêm, ou seja, existe uma relação inversa entre os valores de $\mathrm{pH}$ e os teores de Mn trocável e em solução (Fanquim \& Vale, 1991).

\subsection{Geoestatística}

A aplicação das ferramentas da estatística clássica de Fischer na experimentação agrícola, para que se possam empregar testes de comparação entre tratamentos, está 
vinculada à observação dos pressupostos básicos da análise de variância, tais como: a) independência entre observações; b) independência e homogeneidade entre os erros entre observações; c) aditividade dos efeitos; d) normalidade dos resíduos. No entanto, vários trabalhos têm demonstrado que observações vizinhas, de variáveis do solo apresentam correlação ou dependência espacial (Vieira et al., 1983; Prevedello, 1987; Scott et al., 1994; Cambardella et al., 1994; Cahn et al., 1994; Paz et al., 1996 e Souza, 1999). Outros trabalhos têm evidenciado que observações vizinhas de atributos da planta também não são aleatórias, ou seja, não variam ao acaso, e seguem comportamento espacial (Tabor et al., 1984; Vieira et al., 1987; Mulla, 1993 e Salviano et al., 1995).

Segundo Trangmar et al. (1985), Fietz (1998) e Gonçalves (1997), a estatística clássica assume que a variabilidade do valor de um atributo do solo em torno da média é aleatória e independente da posição espacial dos valores amostrais. No entanto, Vieira et al. (1981) mostraram que a variabilidade de atributos do solo é espacialmente dependente, ou seja, dentro de um certo domínio, as diferenças entre os valores de um atributo do solo podem ser expressas em função da distância de separação entre as observações medidas.

Consequientemente, os valores em locais mais próximos entre si são mais semelhantes, até um determinado limite, que aqueles tomados a maiores distâncias. Caso isto ocorra, os dados não podem ser tratados como independentes e um tratamento estatístico mais adequado será necessário (Eguchi, 2001). Blackwell (1975) afirma que duas variáveis são independentes se a distribuição de cada uma, dados os valores da outra, é sempre igual à sua distribuição incondicional, isto é, não depende dos valores das outras variáveis. Se duas variáveis são independentes elas são, certamente, não correlacionadas.

O problema está em que é impossível saber, antes de amostrar, de que maneira as amostras vão se comportar (dependente ou independente uma da outra). Devido a essas limitações da estatística clássica e pelo fato dos solos serem heterogêneos, pois a maioria de seus atributos varia no espaço e no tempo, torna-se necessária a utilização de procedimentos estatísticos adicionais, que considerem e reflitam essas variações (Silva, 1988). 
Para que se possam empregar os testes de comparação entre tratamentos, a estatística clássica também exige que a variável em estudo tenha uma distribuição de frequiência normal dos dados, o que nem sempre é comprovado (Nielsen et al., 1973 e Salviano, 1996).

Assumindo as hipóteses exigidas pela estatística clássica, pode-se dizer que um valor medido é em parte explicado por uma média e em parte pela variação ao acaso, onde os desvios dos valores em torno da média, são assumidos como sendo independentes e com distribuição normal de média zero e variância $\sigma^{2}$, ou seja, a média aritmética dos dados amostrais é adotada como sendo bom estimador da posição central dos valores da população. A média é então tomada como estimativa do atributo em locais não amostrados, tornando necessário identificar o nível de precisão dessa média como estimador, o que na estatística clássica é realizado por meio das medidas de dispersão (Pimentel Gomes, 1985; Trangmar et al., 1985 e Gonçalves, 1997).

Não assumindo estas hipóteses, os experimentos de uso e manejo do solo estariam violando os pressupostos básicos da análise de variância, devido à variabilidade do solo não ser aleatória e à não normalidade dos dados, o que poderia implicar em uma interpretação errônea dos resultados, reduzindo a conveniência da aplicação da clássica análise de variância (Bhatti et al., 1991 e Ball et al., 1993). É evidente que a estatística clássica, por si só, é insuficiente para retratar fielmente os efeitos dos tratamentos, precisando de formas complementares ou mesmo da definição de novos delineamentos experimentais.

A pesquisa agronômica tem, constantemente, lançado mão de ferramentas da estatística clássica para testar diferenças entre tratamentos. Porém, quando se depara com uma situação onde a variabilidade da variável estudada é muito grande, encara-a como uma dificuldade e, normalmente, muitos dados deixam de ser analisados e publicados, por se considerar que esta variabilidade é um erro, ou resíduo, fruto de fatores não controlados e ao acaso (Reichardt et al., 1986). Quando é verificado que a componente residual da variância é relativamente grande, o que normalmente é indicado por um alto valor do coeficiente de variação experimental (CV), o experimento fica prejudicado, sendo que a causa pode ser a variabilidade do solo, assumido como homogêneo no início, 
ao se estabelecer o experimento (Mata, 1997).

Se a distribuição espacial das amostras for observada e levada em consideração, em muitos casos será possível tirar vantagem da variabilidade espacial (Mata, 1997). É oportuna a observação de Reichardt (1985) de que a estatística clássica e a geoestatística, ou estatística espacial, se completam. Uma não exclui a outra, e perguntas não respondidas por uma, muitas vezes podem ser respondidas pela outra.

A metodologia proposta pelo geoestatística difere da proposta pela estatística clássica, basicamente, na forma de avaliar a variação dos dados. Enquanto a estatística clássica pressupõe não haver relação entre a variação e a distância entre pontos de amostragem, isto é, as variações são aleatórias no espaço, a geoestatística considera existir uma dependência da variação com o espaço de amostragem e que, em parte, essas variações são sistemáticas (Silva, 1988).

Sendo assim, a variabilidade espacial das variáveis pode ser estudada por meio das ferramentas da geoestatística, que se fundamenta na teoria das variáveis regionalizadas, segundo a qual os valores de uma variável estão, de alguma maneira, relacionados à sua disposição espacial e, portanto, as observações tomadas a curta distância se assemelham mais do que aquelas tomadas a distâncias maiores (Vieira et al., 1981 e Vauclin et al., 1983). Uma premissa básica é que em todas as áreas existem regiões mais ricas do que atras, para uma determinada variável. Logo, amostras tomadas numa região mais rica seriam, em média, mais ricas do que aquelas tomadas numa região mais pobre, ou seja, o valor da variável regionalizada depende de sua localização (Souza, 1992 e Mata, 1997), isto é, o valor da variável regionalizada f(x) depende da posição espacial x (Mata, 1997).

O emprego da geoestatística com o objetivo de identificar e avaliar a estrutura espacial das variáveis, introduz uma nova e importante dimensão para a análise da interação entre atributos do solo e das culturas. As ferramentas da geoestatística permitem a análise de dependência espacial, a partir do ajuste de semivariogramas experimentais a uma função simples, segundo um modelo matemático, e a caracterização da variabilidade espacial, por meio do mapeamento da variabilidade a partir da estimativa, sem tendenciosidade, de dados para locais não amostrados. Com a utilização 
destas ferramentas podem-se analisar, adequadamente, dados de experimentos, com a possibilidade de obter informações não reveladas pela estatística clássica (Salviano, 1996). Segundo Folegatti (1996), para o ajuste de semivariogramas a normalidade dos dados não é necessária, mas desejável. Caso a distribuição não seja normal, mas seja razoavelmente simétrica, podem-se admitir as hipóteses necessárias à construção do semivariograma. De acordo com Vieira \& Lombardi Neto (1995), os cálculos utilizados em geoestatística não requerem o conhecimento da distribuição de frequiências da variável analisada.

A obtenção de informações a respeito da variabilidade espacial dos atributos do solo e das plantas é de grande importância para a avaliação da fertilidade; levantamento, mapeamento e classificação de solos; desenvolvimento de esquemas mais adequados de amostragens, entre outros, visando à melhoria das condições de manejo e o incremento de produtividade das culturas (Souza, 1992).

Para aplicação da geoestatística, um conjunto de amostras homogeneamente distribuído na região-alvo seria o ideal, mas isto poderia vir acompanhado por um viés provocado pela presença de algum padrão embutido no próprio perfil da região (Lamparelli et al., 2001). Por essa razão, uma certa aleatorização sempre é preferida. Apesar da aleatorização vir acompanhada por uma certa dificuldade de localização das amostras, e talvez uma incompleta cobertura da área estudada quando o número de amostras não é suficientemente grande, estimadores de estatísticas como média e variância não são viciados nesse caso. Uma mistura dos dois esquemas, regular e aleatório, seria o ideal para que se mantivessem os principais benefícios de cada esquema em separado. A amostragem aleatória estratificada possui parte das vantagens do esquema aleatório e do regular. Os pontos são alocados aleatoriamente dentro de uma célula da grade. Com isso cobre-se parte do problema do viés nas estimativas, ainda mantendo uma distribuição homogênea na área. 


\subsection{Krigagem}

$\mathrm{Na}$ maioria das vezes o interesse da análise geoestatística não se limita à obtenção de um modelo de dependência espacial, desejando-se também predizer valores em pontos não amostrados. $\mathrm{O}$ interesse, pode ser em um ou mais pontos específicos da área ou obter uma malha de pontos interpolados que permitam visualizar o comportamento da variável na região por meio de um mapa de isolinhas ou de superfície. Para se obter esse maior detalhamento da área em estudo é necessária a aplicação de um método de interpolação, como a krigagem (Silva Junior, 2001).

Segundo Gonçalves (1997) e Silva Junior (2001), esse interpolador pondera os vizinhos do ponto a ser estimado, obedecendo aos critérios de não tendenciosidade e mínima variância. Existem diversos tipos de krigagem: simples, ordinária, universal, indicadora, probabilística etc.

Quando seguem distribuição normal, os estimadores de krigagem linear são geral e condicionalmente não-viciados, caso contrário são apenas não-viciados de forma geral e geralmente são condicionalmente viciado (Hawkins \& Cressie, 1984). Alguns trabalhos têm indicado a robustez da krigagem ordinária a certos graus de não-estacionaridade e assimetria da distribuição (Yost et al., 1982 e Bregt et al., 1991).

A krigagem ordinária utiliza um estimador linear não-viciado com mínima variância ("BLUE-Best Linear Unbiased Estimator") para interpolação do atributo medido em posições não-amostradas (Isaaks \& Srivastava, 1989). Linear porque suas estimativas são feitas por combinações lineares; Unbiased (sem viés) porque o erro de estimativa esperado é nulo; e $\underline{\text { best }}$ porque seu objetivo é minimizar a variância destes erros de estimativa (Inoue et al., 1999). O estimador é uma combinação linear que é uma média móvel e leva em conta a estrutura de variabilidade encontrada para aquela variável (medida), expressa pelo semivariograma (ou, equivalentemente, função de autocorrelação) e pela localização dos valores conhecidos (Lamparelli et al., 2001). Pontos próximos da posição a ser interpolada levam maiores pesos que os mais distantes.

De acordo com Silva Junior (2001), o método de krigagem ordinária se distingue dos demais tipos por seu objetivo de minimizar a variância dos erros. Os ponderadores de 
dados na krigagem são proporcionais às "distâncias estatísticas", significando que, além de ponderar pelas distâncias euclidianas entre o ponto a ser estimado e os demais pontos conhecidos, incorporam também a estrutura de variabilidade na região de estimação. Um caso em que isto ocorre é quando a anisotropia, ou seja, dois pontos separados pela mesma distância euclidiana do ponto a ser estimado possuem influência diferente na estimação dependendo da direção onde estão situados, uma vez que a dependência é distinta nas diferentes regiões (Ribeiro Junior, 1995). Salienta-se ainda que as distâncias consideradas não são somente as distâncias entre o ponto a ser predito e os vizinhos, mas também as distâncias entre os vizinhos (Silva Junior, 2001). Exemplificando, supõem-se as situações apresentadas pelas Figuras $2 \mathrm{a}$ e 2b, assumindo fenômenos isotrópicos:

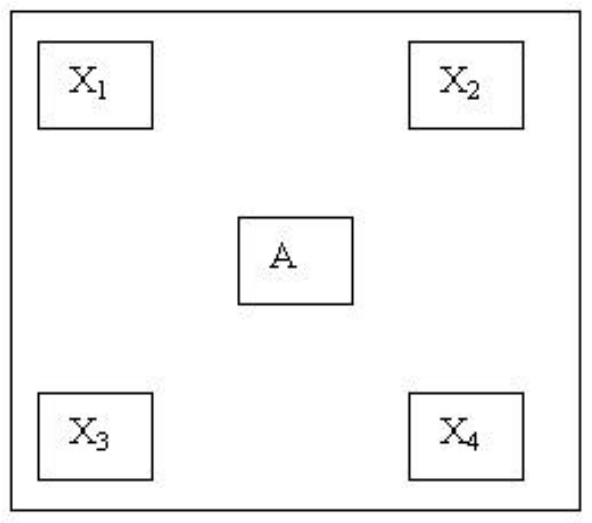

$2 \mathrm{a}$

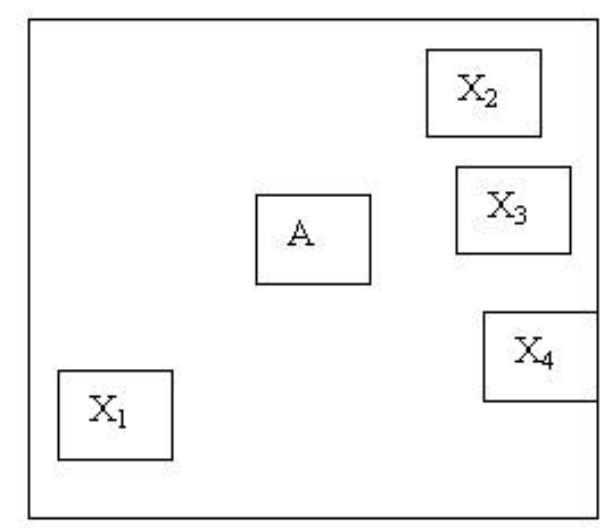

$2 b$

Figura 2 - Diferentes configurações de vizinhança

É razoável que, para a Figura 2a, os pesos de cada ponto sejam semelhantes, uma vez que estão aproximadamente à mesma distância do ponto A e entre si. Na Figura 2b, nota-se um agrupamento de dados. Neste caso é razoável que o peso de $X_{1}$ seja maior que os pesos de $\mathrm{X}_{2}, \mathrm{X}_{3}, \mathrm{X}_{4}$ pois estes dados agrupados trazem informações quase redundantes de uma mesma região (Ribeiro Junior, 1995 e Silva Junior, 2001).

Esta característica deste interpolador é denominada "declustering", devendo-se ao fato do preditor considerar uma medida de associação entre os pontos $\mathrm{X}$ da vizinhança. 
Normalmente, a medida de associação utilizada é a semivariância, e daí a necessidade de se ter um semivariograma e um modelo ajustado (Almeida \& Ribeiro, 1996).

De acordo com Ribeiro Junior (1995) e Camargo (1997), o processo de krigagem se diferencia dos outros métodos de interpolação pela forma de atribuição dos pesos, pois neste método não se utiliza a distância euclidiana entre os pontos, mas uma "distância estatística" que expressa tanto a distância como a estrutura de variabilidade (semivariância ou covariância). Não apenas a distância dos vizinhos ao ponto a ser estimado é considerada, mas também as distâncias entre os mesmos influência a distribuição dos pesos. Assim, os vizinhos agrupados têm importância individual relativamente menor do que aqueles isolados.

No método da krigagem, os pesos são atribuídos de acordo com a variabilidade espacial expressa no semivariograma (Vieira, 1998). No entanto, o que torna a krigagem um interpolador ótimo é a maneira como os pesos são distribuídos, não sendo tendencioso, tendo variância mínima e possibilitar que se conheça a variância da estimativa (Webster \& Oliver, 1990).

A condição de não tendência significa que, em média, a diferença entre valores estimados e medidos para o mesmo ponto deve ser nula. A condição de variância mínima significa que, embora possam existir diferenças ponto por ponto entre o valor medido e o estimado, essas diferenças devem ser mínimas (Fietz, 1998).

Sendo assim a krigagem é uma técnica usada na geoestatística com o objetivo de estimar valores de variáveis para locais onde as mesmas não foram medidas a partir de valores adjacentes interdependentes. Para que esta ferramenta seja usada é necessário que exista a dependência espacial definida pelo semivariograma (Salviano, 1996).

Por meio da análise de mapas de contorno ou de superfície, gerados por meio da krigagem, pode-se tomar decisões importantes, por exemplo, em relação ao aumento da eficiência na utilização de fertilizantes, com redução de custo e aumento de produtividade. Isto porque a aplicação de recomendações médias de fertilizantes, usualmente utilizadas pelos silvicultores, pode resultar em uma super ou subfertilização de uma área, com implicações negativas no ambiente e na relação custo-benefício (Mulla, et al., 1992 e Ribeiro, 2002). O mapeamento da variabilidade espacial dos 
atributos do solo, permite a aplicação de fertilizantes por zonas de manejo, de forma diferenciada, ou seja, utilizando taxa variável, favorecendo a otimização da produtividade, aumentando a eficiência do insumo, maximizando os benefícios e reduzindo custos.

\subsection{Geoprocessamento}

O emprego do geoprocessamento no gerenciamento de unidades de produção florestal, possibilita a geração de um banco de dados, no formato vetorial ou raster, georreferenciados, de acordo com uma única base cartográfica, o que permite efetuar avaliações, análises espaciais e simulações em função de variáveis como pedologia, declividade, geologia, fertilidade, irrigação, produtividade etc., subsidiando tomadas de decisão técnicas e administrativas, de viabilidade, implantação, condução, colheita, manejo, exploração e monitoramento florestal a serem implementadas. Nos trabalhos de Vettorazzi \& Ferraz (2000), Becker (2001), Mcgaughey (2001) e Ribeiro (2002) são apresentadas as principais áreas, dentro do empreendimento florestal, passíveis de serem beneficiadas com o advento da análise espacial, por meio do geoprocessamento.

Segundo Rosa \& Brito (1996), geoprocessamento é o conjunto de tecnologias destinadas à coleta e ao tratamento de informações espaciais, bem como o desenvolvimento de sistemas e suas aplicações. A característica fundamental de um sistema de geoprocessamento é sua faculdade de criar, armazenar, recuperar e analisar mapas num ambiente computacional (Câmara, 1993). Os Sistemas de Informação Geográfica (SIGs) são sistemas destinados à manipulação de dados georreferenciados, ou seja, informações codificadas espacialmente.

Couto (1993) relata que os inventários florestais são fonte de dados para qualquer planejamento florestal e para SIG, o qual não é apenas uma tecnologia, mas sim uma nova filosofia de trabalho para as empresas florestais. Isto porque as empresas florestais, em geral, projetam a distribuição de suas áreas por meio de mapas onde, são representados o relevo, as categorias de solos, a distribuição dos talhões, malha viária etc. Esses dados, juntamente com o inventário florestal, podem ser todos agrupados num 
banco de dados SIG para o gerenciamento das florestas plantadas e para o monitoramento ambiental.

\subsubsection{Mapeamento digital}

Um mapa é uma representação gráfica de fenômenos geográficos, geralmente em uma superfície plana (Câmara, 1993). Num ambiente computacional, a noção de mapa deve ser estendida para incluir diferentes tipos de dados geográficos, os chamados planos de informação (PIs), como os de categorias temáticas que podem ser representados em um plano com duas dimensões (x,y), como o mapa de isolinhas também conhecido como mapa de contorno, ou com três dimensões $(\mathrm{x}, \mathrm{y}, \mathrm{z})$, como o modelo numérico de terreno (MNT).

Exemplo de PIs apresentados em MNT são as curvas de nível e cotas altimétricas, para geração do modelo digital de terreno (MDT). Outro exemplo são os valores amostrais de variáveis físicas e químicas do solo, assim como de parâmetros da planta, para geração do modelo digital de elevação (MDE) de cada nutriente ( $\mathrm{P}, \mathrm{K}, \mathrm{N}$ etc.), micronutriente (B, $\mathrm{Zn}, \mathrm{Cu}$ etc.), granulometria (areia, argila, silte etc.) e de parâmetros da planta (índice de sítio, altura, DAP, capacidade produtiva etc.).

Para sua representação os PIs devem estar georreferenciados em latitude e longitude de acordo com as coordenadas planas x,y e a escala adotada para a base cartográfica, definindo a mesma resolução vertical (número de colunas) e horizontal (número de linhas) para todos os planos, concomitantes a base cartográfica.

Segundo Felgueiras (1987), um MNT é uma representação matemática tratável computacionalmente e que representa a distribuição espacial de uma determinada característica vinculada a uma superfície real. O modelo numérico de terreno é gerado a partir de um conjunto de pontos $\left(\mathrm{x}_{\mathrm{i}}, \mathrm{y}_{\mathrm{i}}, \mathrm{Z}, \mathrm{i}=1,2,3, \ldots \mathrm{n}\right)$ amostrados da superfície real, sendo que as coordenadas $\mathrm{x}$ e y dos pontos estão relacionadas às posições de amostragem na superfície e a coordenada z está relacionada à característica que se quer modelar.

Ou seja, o MNT é uma representação digital, em 3D da área de estudo, contendo valores de $\mathrm{x}, \mathrm{y}$ e $\mathrm{z}$ correspondentes a cada pequena área no terreno, ou seja, cada célula 
que compõe a grade amostral. Os valores digitais, são dispostos numa forma matricial onde os índices das linhas e colunas da matriz do MNT identificam as coordenadas espaciais (x,y) e o valor numérico de cada elemento da matriz identifica o valor predominante na célula, chamado de atributo numérico $(\mathrm{z})$.

\subsection{Relação entre produtividade e atributos do solo e do relevo}

Em princípio, pode ser relativamente simples enumerar fatores do ambiente que influem no crescimento de uma cultura, como por exemplo árvores de um povoamento de eucalipto. Entretanto, pode ser difícil entender e avaliar o somatório de interações desses fatores e os seus efeitos sobre o crescimento da cultura, no caso a floresta. A integração e análise de todos os fatores do meio para estimar o rendimento ou produtividade do cultivo pode ser realizada por meio da aplicação de diversos métodos e técnicas, geralmente estatística clássica, geoestatística e geoprocessamento, com ferramentas e enfoques diferentes, como apresentado nos tópicos a seguir.

\subsubsection{Aplicação da estatística clássica na área florestal}

O trabalho de Goor (1965a), abordou a relação entre o crescimento e a qualidade (condições de solo e clima) dos reflorestamentos com coníferas na região sul do Brasil, mais especificamente Pinus elliotti e Araucaria angustifolia. Foram tomadas 162 parcelas em cada qual foram medidas pelo menos 25 árvores e realizada a coletada de uma amostra de solo na profundidade de $\theta 25 \mathrm{~cm}$. Realizoutse a análise de correlação e variância entre o volume de madeira com as variáveis químicas estudadas para determinar o coeficiente de correlação. Os maiores coeficientes de correlação alcançados foram de 0,56 tanto para $\mathrm{Ca}+\mathrm{Mg}$ como para $\mathrm{Na}+\mathrm{K}+\mathrm{Mg}$ relacionados com qualidade do reflorestamento. Os resultados apontam que a baixa fertilidade química do solo, a deficiência de $\mathrm{Ca}+\mathrm{Mg}$, clima com inverso seco e presença de solos rasos atuam negativamente no crescimento das plantas e na qualidade do reflorestamento. Solos rasos normalmente possuem espaço restrito para o desenvolvimento das raízes e, conseqüente, 
absorção de água e de nutrientes, tornando difícil e limitada. Em solos com susbstratos ácidos, a quantidade de $\mathrm{Ca}+\mathrm{Mg}$ trocáveis é o principal fator determinante do crescimento.

Barros (1974) estudou povoamentos de Eucalyptus urophylla situados na Zona Metalúrgica de Minas Gerais, região de Santa Bárbara, com o objetivo de relacionar características pedológicas e topográficas com o crescimento em altura de E. urophylla. Foram estabelecidas 32 parcelas amostrais em cada um dos 2 povoamentos estudados, ambos com espaçamento $2 \mathrm{~m}$ x 2m, o primeiro denominado de Dacó, com 6 anos de idade e situado sobre latossolo vermelho amarelo distrófico orto textura argilosa, e, o outro, Alegria, com 7 anos de idade, situado sobre associações de solos litólicos distróficos, afloramento de rocha, latossolo vermelho escuro distrófico orto textura argilosa e cambissolo distrófico. Em sua maioria as parcelas apresentaram área de 504 a 600 $\mathrm{m}^{2}$. Em cada parcela mediu-se a altura total de 10-15 árvores dominantes, o DAP de todas as árvores, recolheram-se as amostras de solo do horizonte $\mathrm{A}$ e à profundidade de $50 \mathrm{~cm}$ do $\mathrm{B}$, bem como se determinou a declividade, a exposição da parcela, a forma do terreno e a profundidade dos horizontes. As relações dos parâmetros de produtividade com os atributos do solo e da topografia estudados foram determinados por análise de regressão múltipla linear, com o cálculo do $\mathrm{r}$ e $\mathrm{R}^{2}$, teste t e teste F. No povoamento de Dacó, a declividade foi a característica que mais afetou o crescimento em altura do E. urophylla. Das características pedológicas do horizonte A, a disponibilidade de água e os teores de Al trocável, de fósforo, de potássio e de cálcio + magnésio trocáveis foram as que apresentaram efeitos significativos relativamente à altura nos melhores modelos estabelecidos, alcançando $\mathrm{R}^{2}=94,6 \%$. No horizonte $\mathrm{B}$, a declividade, face de exposição, \% de areia, disponibilidade de água, teores de $\mathrm{Al}$ trocável e de $\mathrm{MO}$ e a saturação de alumínio foram as características que mais afetaram o crescimento em altura, sendo que o melhor modelo apresentou $\mathrm{R}^{2}=71,6 \%$. No povoamento de Alegria, para o horizonte $\mathrm{A}$, ao $\mathrm{pH}$, teores de argila, de MO, de fósforo, e de cálcio + magnésio trocáveis foram as características mais importantes, afetando o crescimento do E. urophylla, sendo que o melhor modelo estabelecido, alcançou $\mathrm{R}^{2}=71,6 \%$. Para o horizonte $\mathrm{B}$ o melhor modelo apresentou $\mathrm{R}^{2}=70,7 \%$. No estrato litólico as características do horizonte $\mathrm{A}$ mais 
importantes foram a declividade, equivalente de umidade e os teores de $\mathrm{MO}$ e de fósforo, sendo o melhor modelo $\mathrm{R}^{2}=84,1 \%$. Neste mesmo estrato, no horizonte $\mathrm{B}$, a declividade $\mathrm{e}$ a espessura do horizonte foram as únicas características que afetaram de modo significativo a altura, sendo que o melhor modelo apresentou $\mathrm{R}^{2}=81,7 \%$. No estrato latossólico, no horizonte A, o teor de argila e o de fósforo foram as características mais importantes com $\mathrm{R}^{2}=98,8 \%$. No horizonte $\mathrm{B}$, o teor de argila, a $\%$ de areia, a disponibilidade de água, os teores de $\mathrm{Al}$ trocável, de fósforo e a saturação de bases se mostraram como as características mais importantes com $\mathrm{R}^{2}=94,1 \%$.

$\mathrm{Na}$ pesquisa de Hoogh \& Dietrich (1979), foram abordadas as relações crescimento-sítio para Araucaria angustifolia em 260 parcelas, com plantas com idade superior a 5 anos, no sul do Brasil. Os fatores climáticos (precipitação e temperatura média anual), geográficos (latitude e altitude), topográficos (declividade, face de exposição) e edáficos (características químicas na profundidade de $0-25 \mathrm{~cm}$ ), bem como da vegetação, foram relacionados ao índice de sítio, usando análise de correlação e regressão múltipla por etapas sucessivas com modelo linear, para calcular o $r$ e $R^{R}$ entre as variáveis independentes com a dependente. Os atributos que mostraram maior significância, em relação ao índice de sítio, foram vegetação anterior ao plantio $(\mathrm{r}=0,53)$, porcentagens de saturação de bases $(\mathrm{r}=0,41)$ e profundidade do horizonte A e B $(r=0,61)$. As duas equações, determinadas pela análise de regressão para estimar o valor da variável dependente (IS), com melhor ajuste conseguiram explicar $74 \%$ e $80 \%$ das variações do IS, sendo que ambas contaram com $\mathrm{pH}$, profundidade do solo, $\mathrm{m} \%$ e CTC como variáveis explicativas. Além destas variáveis, a equação que explica $80 \%$ contou com $\mathrm{Ca}+\mathrm{Mg}$. Os solos profundos, bem drenados, demonstraram ser indicados para o crescimento das araucárias. Concluem que os atributos do sítio que determinam o crescimento da araucária variam em combinação e interação de local para local e que uma vegetação anterior, de floresta primária ou secundária, um horizonte $\mathrm{A}$ bem desenvolvido, um alto conteúdo de $\mathrm{Ca}+\mathrm{Mg}$ no solo ou um alta porcentagem de saturação de bases, e um solo profundo, friável, poroso e bem drenado, formam condições ideais para o crescimento da araucária. 
Brum (1979) observou, por meio de correlação e regressão múltipla "forward" no SPSS, as relações entre a altura média das árvores dominantes e parâmetros topográficos, edáficos e fisiológicos, como subsídios para a classificação de sítio em povoamentos de P. elliottii. O estudo foi executado em Ponta Alta do Norte (SC) em uma área pertencente à SEIVA Florestas e Indústrias, com o cultivo aos 8 anos de idade. Foram amostradas 14 parcelas com área de $600 \mathrm{~m}^{2}$. Onde foram coletadas acículas, informações topográficas, efetuada a abertura de um perfil do solo e coleta de amostras de solo em diversas profundidades, posteriormente cada parcela foi subdividida em três subparcelas, em cada qual foi medida a altura, diâmetro e fuste das 5 árvores dominantes e codominantes. Foi observado que o silte do solo apresentou correlação significativa em relação à altura, $\mathrm{r}=-0,57$ e $-0,66,0-20 \mathrm{~cm}$ e $20-50 \mathrm{~cm}$ respectivamente, o teor de magnésio na manta e $\mathrm{pH}$ na profundidade $0-20 \mathrm{~cm}$ também mostraram correlação negativa com altura, $\mathrm{r}=-0,59 \mathrm{e}$ -0,54 respectivamente. Também foram analisadas as correlações entre altura e variáveis dependentes, separadamente, em 3 estratos do relevo, elúvio, colúvio e 1/3 inferior do colúvio. $\mathrm{O}$ maior $\mathrm{R}^{2}$ atingido pela análise de regressão múltipla atingiu $97 \%$. Conclui que o relevo atua como um fator decisivo no crescimento, sendo que no futuro, as classificações de sítios deverão considerar, também as condições topográficas, por meio dos efeitos do relevo.

No trabalho de Santana (1986), foi estudada por meio de regressão linear míltipla a relação entre produtividade-solo em povoamentos de $C$. citriodora e E. saligna localizados no município de Dionísio (MG) e pertencentes a CAF, em parcelas localizadas nos topos, encostas e baixadas. Conclui que o E. saligna mostrou-se uma espécie pouco exigente em nutrientes, parecendo ser mais dependente de boas características físicas que permitam maior desenvolvimento do sistema radicular e retenção de água. Este fato torna-se mais patente observando produtividade menor em talhões apresentando solos com níveis de fertilidade elevados, mas com dificuldade de drenagem, o que parece confirmar a importância dos parâmetros físicos do solo relacionados com a dinâmica da água, e a facilidade de penetração do sistema radicular, na produtividade da espécie. Também conclui que as encostas côncavas mostraram-se mais férteis para $C$. citriodora. As maiores produtividades foram obtidas nestes sítios, 24 
$\mathrm{m}^{3}$ /ha/ano, possivelmente como resultado do maior nível de fertilidade e pelo fato de possuírem relevo que possibilita menor perda de água do sistema, seguida das encostas convexas $\left(16 \mathrm{~m}^{3} / \mathrm{ha} / \mathrm{ano}\right)$ e por último o topo $\left(15 \mathrm{~m}^{3} / \mathrm{ha} / \mathrm{ano}\right)$ Nesta última posição, verificaram-se os mais baixos teores de todos os parâmetros químicos analisados, exceto quanto ao alumínio trocável e a matéria orgânica, ao contrário da encosta côncava, que, além de ser mais rica em nutrientes, apresenta um pedoclima mais favorável. A baixa fertilidade dos solos no topo é o fator limitante ao desenvolvimento do C. citriodora, principalmente em relação ao fósforo, cálcio, magnésio e potássio. Para esta espécie foram estabelecidos 3 modelos de predição da produtividade a partir dos valores das características ambientais estudadas que mais se correlacionaram com a produção, de acordo com a geomorfologia do relevo (topo, encosta convexa e encosta côncava). Novamente fica evidente a importância dos parâmetros físicos relacionados com a dinâmica de água no solo para a produtividade da espécie. O equivalente de umidade, na profundidade entre 50 e $100 \mathrm{~cm}$, foi a única característica que apareceu em 2 modelos, refletindo a importância da disponibilidade de água no solo, para o desenvolvimento do C. citriodora. Para o E. saligna a densidade do solo, na profundidade entre 50 e $100 \mathrm{~cm}$, foi a única característica que apareceu em 2 modelos, de acordo com a geomorfologia do relevo (topo, encosta e baixada).

Gonçalves (1987) verificou as prováveis variáveis do solo responsáveis pela diferente produtividade apresentada por plantios comerciais de Eucalyptus grandis, com 5 anos, em Angatuba-SP, num latossolo vermelho amarelo distrófico, textura arenosa, 40,64ha, e em areia quartzosa, 39,57ha. Foram estabelecidos 16 pontos de amostragem, sendo 8 em cada solo; coletadas amostras de solo em 8 diferentes profundidades, entre 10 e $110 \mathrm{~cm}$; e medido o DAP de todas as árvores da parcela, altura total de 20 árvores, e percentual de falhas em cada parcela. Os resultados, a partir da comparação estatística das médias por meio do teste $\mathrm{t}$ não pareado, apontaram que a produtividade florestal, $20 \%$ superior no latossolo (240,46 st cc/ha) comparada a da areia quartzosa (202,23 st cc/ha), estava associada àmatéria orgânica, CTC e teores de argila.

O estudo de Cardenas (1987), realizado em povoamentos de E. grandis no litoral norte do estado de Espírito Santo, objetivou avaliar e correlacionar parâmetros de 
crescimento e algumas características do solo. Foram locadas 17 parcelas, com área aproximada de $20 \mathrm{~m}$ x $30 \mathrm{~m}$, em diferentes talhões e posições topográficas, com diferentes procedências e idades (entre 7 e 9 anos), a maior parte com espaçamento 2,73m x 2,73m e diferentes produtividades (variando entre $32,6 \mathrm{~m}^{3} / \mathrm{ha} / \mathrm{ano}$ e $110,2 \mathrm{~m}^{3} / \mathrm{ha} / \mathrm{ano}$ ). Na área de cada parcela foram abertas cinco trincheiras (uma no centro e as demais nos vértices das parcelas), com aproximadamente $0,80 \mathrm{~m} \times 1,20 \mathrm{~m}$ até $0,60 \mathrm{~m}$ de profundidade, para a coleta das amostras de solo. Foram medidos os DAPs de todas as árvores de cada parcela, mais a altura das 5 árvores dominantes. As relações existentes entre o incremento médio anual em altura das árvores dominantes e as características do solo, foram determinadas por meio de regressão linear múltipla. As melhores estimativas da altura dominante e biomassa seca por meio dos modelos ajustadas na regressão múltipla com variáveis do solo, foram obtidas para as amostras na profundidade de $0-30 \mathrm{~cm}, \mathrm{R}^{2}=97 \%$ e $\mathrm{R}^{2}=90 \%$ respectivamente, já para a profundidade $020 \mathrm{~cm} \mathrm{R}>60 \%$ e $\mathrm{R}^{2}<70 \%$ respectivamente Os resultados obtidos apontam que o crescimento foi mais influenciado pelas características químicas das camadas superficiais do solo e pelas características físicas das camadas mais profundas. Correlações negativas foram observadas entre os parâmetros de produtividade e $\mathrm{pH}, \mathrm{P}, \mathrm{K}, \mathrm{Ca}, \mathrm{Mg}$ e $\mathrm{C}$; e positivas para o teor de $\mathrm{Al}$ trocável, diferindo das informações concernentes às respostas obtidas a aplicações de fertilizantes minerais em solos de baixa fertilidade.

O trabalho de Teixeira (1987), realizado no município de Dionísio (MG), região do Médio Rio Doce, em povoamentos de Eucalyptus spp, teve como um dos objetivos, estudar a influência da posição topográfica, características químicas do solo e características silviculturais (espécie e número de rotações) sobre a produção de biomassa. Foram selecionados 7 talhões, sendo 3 de E. saligna e 4 de C. citriodora. Após a seleção dos talhões foram locadas 38 parcelas, de $20 \mathrm{~m}$ x $30 \mathrm{~m}$, sendo 14 de E. saligna e 24 de C. citriodora, distribuídas nas variações da toposequência (topo, encosta convexa, encosta côncava, meia encosta e baixada). Os talhões apresentavam espaçamento $2 \mathrm{~m} x$ 2m, diferentes idades (com o ano de plantio variando de 1958 à 1972, sendo que os dados foram coletadas em 1984), e diferentes números de rotações $\left(1^{\mathrm{o}}, 2^{\mathfrak{0}}\right.$ e $3^{\mathrm{o}}$ cortes). Foram coletadas medidas de DAP e amostras da manta orgânica, depositada sobre o solo, em 
cada parcela. Os resultados demonstraram que os solos do topo apresentavam limitação de nutrientes, principalmente de $\mathrm{Ca}$, e os solos das baixadas apresentavam nível de fertilidade mais elevado, como maior disponibilidade de $\mathrm{P}$ e $\mathrm{Mg}$, mas sem que isto se traduzisse em maior produtividade, uma vez que as características físicas destes solos, tais como profundidade, permeabilidade e porosidade, se mostraram menos adequadas para o crescimento das plantas do que as do topo.

Barros et al. (1990) procuraram estabelecer a influência dos aspectos edáficos sobre o crescimento de várias espécies de eucalipto na Austrália. Foram selecionadas regiões representativas de ocorrência de cada espécie, onde amostras de solos foram coletadas na camada de $025 \mathrm{~cm}$, para posterior análise física (textura) e química $(\mathrm{pH}, \mathrm{P}$, $\mathrm{K}, \mathrm{Al}, \mathrm{Ca}$ e $\mathrm{Mg}$ ), além de uma análise climática (temperatura, precipitação) e topográfica da área. Com os resultados obtidos conseguiram caracterizar as condições ideais das variáveis estudadas para o crescimento de E. urophylla, E. camaldulensis, C. citriodora, E. cloeziana, E. microcorys, E. pellita, C. torelliana, E. pilularis, E. pyrocarpa, E. dunnii, E. saligna e E. tereticornis, assim como agrupar as espécies por qualidade de sítio, permitindo a seleção dos ecótipos apropriados para o plantio em condições específicas no Brasil.

A pesquisa de Gonçalves et al. (1990), determinou as relações existentes entre a produtividade de sítios de E. grandis e E. saligna com alguns atributos físicos e químicos de solos com baixo potencial produtivo no estado de São Paulo. Os sítios apresentavam homogeneidade de "stand", características climáticas e topográficas semelhantes. Por outro lado, foram bastante diversos quanto às suas produtividades e atributos edáficos. No total foram selecionados 18 sítios de E. grandis e 08 sítios de E. saligna, em cada qual foram demarcadas uma parcela com área de $550 \mathrm{~m}^{2}$, com 100 árvores, posteriormente foram avaliadas a altura média das árvores dominantes, índice de sítio, DAP médio e algumas medidas de volume. Foram coletadas amostras de solo nas camadas de $0-10 \mathrm{~cm}, 10-20 \mathrm{~cm}, 20-30 \mathrm{~cm}, 40-60 \mathrm{~cm}$ e $100-120 \mathrm{~cm}$ de profundidade. As relações existentes entre as produtividades dos sítios e as características físicas e químicas dos solos foram determinadas por meio de análise de regressão múltipla. Concluíram que a camada superficial do solo, de 0-20 cm de profundidade, é a mais 
indicada para amostragens destinadas à avaliação de fertilidade de solo para fim de implantação de povoamentos de E. grandis e E. saligna, quando comparadas com os resultados para as camadas de 20-30, 40-60 e 100-120 cm. Os atributos $\mathrm{pH}$ em $\mathrm{CaCh}$, teor de silte, teor de fósforo assimilável, teor de $\mathrm{SiO}_{2}$ da argila e teor de matéria orgânica foram os que apresentaram melhores relações com a produtividade do sítio. Verificou-se que as frações texturais finas (silte e argila) relacionaram-se diretamente com o crescimento das árvores, pois assumem papéis fundamentais na capacidade de retenção de umidade e nutrientes, particularmente nos solos de textura arenosa. Entretanto, quando os teores dessas frações se elevam consideravelmente, verificou-se um comportamento inverso com relação o crescimento das árvores, atribuído fundamentalmente, ao comprometimento do sistema de aeração da atmosfera edáfica.

No estudo de Carmo et al. (1990), foi realizada uma abordagem direcionada à caracterização de ambientes florestais, em que atributos pedoclimáticos foram utilizados como definidores de ambientes, assim como fornecer alguns parâmetros, além de exercitar modelos preditivos, objetivando a um melhor entendimento dos fenômenos envolvidos no processo produtivo florestal. Concluem que a definição e a avaliação de sítios florestais não podem ser feitas com base apenas em características isoladas mas, em uma síntese de qualidades do ecossistema, assim como um sistema de classificação de sítios quanto à produtividade florestal deve ser capaz de avaliar as principais relações entre o crescimento do eucalipto e as variações edáficas, além de considerar a eficiência de utilização de nutrientes, inertes a cada espécie ou clone, em ambientes distintos.

O trabalho de Shorter (1993), avaliou o efeito de diferentes variáveis do solo e do clima sobre o desenvolvimento de 10 clones de E. grandis, aos 2 anos e oito meses de idade, plantados em 3 locais no sul da Bahia. Em cada parcela experimental, no total de 90, sendo 30 para cada local, foram medida a altura máxima das 9 árvores centrais e DAP. Em cada parcela, 90 no total, foram abertas entre 2 e 3 trincheiras, das quais algumas amostras de perfis de solo, 0-20;40-60; 80-100 $\mathrm{cm}$ de profundidade, foram coletadas e submetidas a análises físicas (determinação do teor de argila, silte, areia grossa e fina) e químicas (determinação do $\mathrm{pH}$ em $\mathrm{CaCb}$, porcentagem de matéria orgânica, P, K, Ca, S e Mg, acidez potencial, soma de bases, e capacidade de troca de 
cátions e saturação por bases). No programa SAS foram realizadas análises de variância, matrizes de coeficientes de correlação e regressões múltiplas. Após o exame de modelos obtidos por análises de regressão realizadas pelo método passo-a-passo ("stepwise"), e de coeficientes de correlação de Pearson, concluiutse que o teor baixo de silte aparentou relação negativa com o crescimento das plantas. $\mathrm{O} \mathrm{R}^{2}$ do modelo ajustado previsivo ajustado envolvendo todas as variáveis independentes e a variável dependente (altura) foi baixo, $40 \%$. Em termos de fertilizante, o efeito mais marcante foi o teor de matéria orgânica nas camadas subsuperfíciais, que parece beneficiar o crescimento, e pode estar ligado a uma causa física associada provavelmente ao clima seco. A principal causa das diferenças de produtividade observadas entre os locais, foi a deficiência hídrica, aliada ou não com a resistência a penetração do solo pelas raízes.

Correia (1993) e Correia et al. (1996) aplicaram o método análise de trilha ("Path Analysis"), para estabelecer relações entre características de diferentes camadas do solo e a produtividade em 28 talhões de E. grandis na Cia. Suzano de Papel e Celulose, no município de Itapetininga, SP. Foi aplicada análise de regressão múltipla para determinação do coeficiente de determinação e posterior seleção das variáveis que mais explicavam as diferenças de produtividade detectadas, assim como os efeitos diretos e indiretos das variáveis independentes sobre a dependente (produtividade). Com base em dados de perfil dos solos (profundidade 0-20, 50-70 e 90-110 cm) e do mapa planialtimétrico foi observado que as características físicas do solo foram mais importantes na determinação da produtividade do que as químicas, à medida que a textura passou a ser mais grosseira, nas maiores profundidades do perfil, menores foram as produtividades do eucalipto. As variáveis químicas só apresentaram efeitos sobre a produtividade quando consideradas em conjunto; isoladamente, não foram capazes de explicar diferenças na produtividade. $\mathrm{O}$ melhor modelo ajustado para as variáveis químicas foi composto por dados do $\mathrm{pH}, \mathrm{Ca}, \mathrm{Mg}, \mathrm{K}, \mathrm{Al}, \mathrm{P}$, Carbono Orgânico e CTC, os quais explicam $82 \%$ das variações da produtividade, sendo superior ao modelo ajustado com as variáveis físicas composto pela textura (argila, silte, areia grossa e fina) e cor do solo que atingiu $\mathrm{R}^{2}=73 \%$. A variável que teve maior correlação com a produtividade foi areia grossa, com r=-0,46 e $-0,36$ na profundidade de 90-110 e $50-70 \mathrm{~cm}$ 
respectivamente. Concluem que grandes teores de areia grossa no solo podem levar à redução no armazenamento de água e no transporte de nutrientes no solo, prejudicando a absorção de nutrientes pelas plantas, sendo portanto a capacidade de retenção de umidade do solo, um dos principais fatores limitantes ao crescimento do eucalipto.

A pesquisa de Gomes \& Zen (1995), abordou o estudo da relação entre as variáveis do solo, nos perfis de 0-30, 30-60, 60-100 e 100-200 cm e a produtividade de $E$. grandis, em 4 fazendas da Cia Suzano de Papel e Celulose, no estado de São Paulo. Foram tomadas 44 amostras de solo, sendo detectadas inicialmente 21 variáveis independentes por perfil estudado, o que totaliza 84 variáveis do solo, além da variável dependente (produção). A utilização do método de componentes principais, combinado com o passo-a-passo utilizando o pacote estatístico SAS, permitiu obter a equação linear do volume de madeira, em st/ha.ano, em função de apenas 25 variáveis do solo, sendo 12 da camada de 0-30 e 13 da de 30-60 cm, com $\mathrm{R}^{2}=95,7 \%$ e $\mathrm{R}^{2}=89,6 \%$. Concluem que é possível estudar o solo utilizando somente amostras de $060 \mathrm{~cm}$ de profundidade e com apenas 38 determinações físicas e químicas.

O estudo de Novais et al. (1995), teve como objetivo a análise da dinâmica dos nutrientes no sistema solo-planta, em plantações de E. saligna no Rio Grande do Sul. Amostras de solo foram coletadas em 01 talhão (com área entre 7-17ha) de cada um dos 08 sítios, e submetidas a análises químicas para determinar os teores de $\mathrm{P}, \mathrm{K}, \mathrm{Ca}$ e $\mathrm{Mg}$. Em áreas inventariadas, em torno de cada perfil, foi determinada a produção de biomassa da madeira. Os solos originados de arenito e de depósitos inconsolidados apresentaram os menores teores de $\mathrm{K}$ disponíveis no solo, resultando em um maior eficiência na utilização deste nutriente. Os teores de $\mathrm{P}$ foram baixos em todos os perfis estudados, sendo o nutriente mais limitante para a produção atual e futura de madeira.

Mello et al. (1995) estabeleceram relações entre os atributos do solo e a produtividade de E. saligna no Rio Grande do Sul e separam os diferentes sítios estudados, em grupos semelhantes com base em atributos químicos do solo. Amostras de perfis de solo foram coletadas em 1 talhão de cada um dos 08 sítios (com área entre 7 17ha), e submetidas a análises químicas para determinar os teores de $\mathrm{N}, \mathrm{P}, \mathrm{K}, \mathrm{Ca}, \mathrm{Mg} \mathrm{e}$ S. Em áreas inventariadas, em torno de cada perfil, foi determinada a produção de 
biomassa. Os dados foram submetidos à análise de correlação e regressão, de trilha e de agrupamento, para o cálculo do $\mathrm{r}$ e $\mathrm{R}^{2}$. As variações entre a produtividade de madeira nos sítios foram explicadas por variações nos teores dos nutrientes do solo. Dentre as variáveis estudadas, o $\mathrm{P}$ relativo ${ }^{3}$ na profundidade de $0-20 \mathrm{~cm}(\mathrm{r}=0,41)$, o teor de $\mathrm{S}$ de 40 $70 \mathrm{~cm}(\mathrm{r}=0,74)$ e o P relativo na profundidade de $100-130 \mathrm{~cm}(\mathrm{r}=0,63)$, foram as que apresentaram maior influência sobre a produção de madeira. Conseguiram distribuir os sítios em cinco grupos heterogêneos, com base na similaridade dos atributos químicos do solo, de acordo com o maior e menor potencial produtivo.

No trabalho de Braga (1997) e Braga et al. (1999), foi aplicada a técnica estatística múltipla, análise discriminante e método passo-a-passo, a partir da relação solo-sítio, com o objetivo de identificar as características ambientais determinantes da qualidade de sítios florestais de E. grandis, numa área com 1.465ha, localizada no município de São João Evangelista (MG). Foram avaliadas características físicas e químicas do solo, espessura de horizontes, fisiografia e insolação, sendo utilizado o programa Statistics Package for the Social Sciences (SPSS), análise de variância e teste F, a 10\%, para pré-selecionar as variáveis com maior poder discriminatório. Foi gerado um modelo discriminante, com duas funções lineares, que classificou corretamente $86,2 \%$ das parcelas nas classes de sítios originais. As 8 características ambientais inclusas no modelo, e as mais importantes foram: altitude, pedoforma, declividade, radiação solar, floculação de argila $(0-20 \mathrm{~cm})$, relação silte/argila $(40-60 \mathrm{~cm})$ e relação cálcio/soma de bases trocáveis $(0-20 \mathrm{~cm}$ e 40-60 cm). Concluem que a análise discriminante foi eficiente para a identificação das características ambientais determinantes da capacidade produtiva dos sítios estudados; que as características fisiográficas destacaram-se, representando, indiretamente, fatores de ação direta sobre o crescimento do povoamento; e que as áreas de maior potencial produtivo apresentaram baixa declividade, exposição norte-nordeste, pedoforma côncava e posição mediana ou inferior na encosta, relativamente distantes dos topos da paisagem.

O estudo de Amaral (2000), avaliou as características pedológicas, físicas,

\footnotetext{
${ }^{3}$ Fósforo relativo $\left(\mathrm{P}_{\mathrm{R}}\right)$ é o teor de fósforo extraído com Mehich-1 x teor de argila / 10.
} 
químicas, mineralógicas e micromorfológicas de cinco diferentes classes de solos da região de Santa Barbara (MG), com plantações de E. grandis com 02 anos de idade pertencentes a CENIBRA S.A., em diferentes posições na topografia, e suas relações com a produção de biomassa e eficiência nutricional. Os resultados obtidos indicam que a restrição ao crescimento da floresta parece condicionada pelos baixos teores de bases que os solos apresentam. Encontrou os maiores teores de $\mathrm{Ca}^{2+}$ e $\mathrm{Mg}^{2+}$ em amostras de solo localizadas em uma posição mais baixa do terreno, que conta com a contribuição de nutrientes transportados dos locais mais elevados. Um dos sítios florestais mais produtivos estava sob cambissolos, o que possivelmente está relacionado à sua posição na paisagem e as características físicas do perfil. Sua localização na parte mais baixa do terreno condiciona maior manutenção de água e nutrientes no sistema, o que é confirmado pelos valores da análise química de rotina do solo. Entretanto, estes valores, com exceção do cálcio, são comparáveis a outros sítios menos produtivos, localizados na parte superior da encosta. Assim, a condição de maior umidade do local devido ao relevo possibilitou maior crescimento. Alguns sítios mesmo apresentando teores de nutrientes no solo inferiores a outros, apresentaram produção superior, que parece estar mais relacionada às características físicas do solo (maior profundidade efetiva e teor de silte) e menos com as características químicas. A densidade do solo e a ausência de impedimento físico permitem o crescimento do sistema radicular de forma a explorar maior volume de solo, compensando os baixos teores dos nutrientes e possibilitando maior absorção de água. Concluiu que o cálcio e o magnésio foram os nutrientes que apresentaram maior restrição ao crescimento da floresta.

\subsubsection{Aplicação da geoestatística e do geoprocessamento na área florestal}

A pesquisa de Conde \& Cornacchioni (1994), apresenta o SIG utilizado pela Cia. Suzano de Papel e Celulose para análises e modelagens espaciais intrínsecas a distribuição de localidades, e informações sob variadas condições climáticas, topográficas e de solos. Segundo os autores os mapas de solos, digitais e georreferenciados, com características físicas e químicas sobrepostos aos mapas de 
produtividade e classes de declividade permitem detectar os fatores influenciadores de diferentes produtividades, assim como determinar o melhor manejo a ser aplicado em cada situação. Trabalhos semelhantes foram encontrados, apresentando a implantação e aplicações do SIG em outras empresas florestais, como a Aracruz Celulose; Klabin Riocell; Klabin - Divisão Paraná; Eucatex; Champion Papel e Celulose; Pisa Florestal; Jari Celulose e Battistella/Mobasa.

No trabalho de Courseuil \& Madruga (1998), foi utilizada modelagem numérica de terreno (MNT), no SIG Idrisi 4.1, para a visualização tridimensional do relevo e sobreposição dos planos de informações relativos aos sítios florestais assentados sobre o mesmo; álgebra de mapas e tabulação cruzada entre estes planos de informações e posterior geração de mapas derivados para a área correspondente a Floresta Nacional de Passo Fundo. Pode-se observar, a partir da análise dos arquivos em 3D gerados, a distribuição espacial dos diferentes sítios, sendo que ao mais produtivos encontravam-se nos pontos mais altos e os menos produtivos nos pontos mais baixos do modelo. Concluem que a partir da metodologia utilizada podem-se identificar as áreas e as características naturais mais apropriadas ao crescimento das espécies implantadas, assim como possíveis áreas para reforma da floresta.

Payn et al. (1999) estudaram o potencial do SIG (ARC/INFO) e de técnicas de análise espacial como ferramentas para monitoramento de mudanças na produtividade e na nutrição de florestas comerciais na Nova Zelândia, numa área com 35.000ha. Foram coletadas 16 amostras do solo (para análises física e química) e 110 de plantas (para estimativa de produtividade). Efetuaram a estatística descritiva dos conjuntos de dados e, posteriormente utilizaram a geoestatística para ajuste de semivariogramas, e interpolação por krigagem dos dados das variáveis estudadas, assim como o geoprocessamento para a produção de mapas que posteriormente foram analisados para verificar tendências temporais e espaciais das variáveis, como crescimento das árvores e atributos do solo. Também foi utilizada estatística, no SAS, para análise de variância das médias dos atributos estudados em diferentes regiões dentro da área de estudo. A análise de variância indicou que vários dos atributos estudados apresentavam estatisticamente, concentrações diferentes de acordo com a região que ocupavam dentro da área de estudo, ou seja, 
variabilidade espacial. Com o SIG foi possível visualizar a variabilidade espacial em mapas, assim como dividir este em subregiões de acordo com a concentração verificada do atributo e calcular a área de cada subregião. Concluem que tanto a geoestatística, como o SIG, são ferramentas válidas para identificar, visualizar, calcular e interpretar tendências de crescimento da produtividade no espaço, mas que neste estudo, os dados de solo e planta coletados foram escassos para o bom uso destas técnicas, o que certamente influenciou para a fraca dependência espacial detectada para os atributos estudados. Soma-se a isto a distribuição demasiadamente irregular dos pontos de amostra, com isto ocorreu um número limitado de pontos de amostra em algumas regiões dentro da área, o que poderia causar erros significativos de interpolação nessas regiões onde é baixa a densidade de pontos.

A pesquisa de Douglas et al. (2000), em Prince Edward Islands, numa área de 575.000ha, procurou avaliar e estabelecer indicadores de qualidade do solo. Foram selecionados "grids" com 4km x 4km, totalizando 232 locais de amostra georreferenciados por GPS. Foram medidos três grupos de parâmetros: físicos (profundidade dos horizontes A e B, grau de declive, posição de amostra no declive, crescimento da produção e tipo de lavoura); químicos (M.O, carbono total, pH, P, K, Ca, $\mathrm{Mg}, \mathrm{B}, \mathrm{Zn}, \mathrm{S}, \mathrm{Mn}, \mathrm{Fe}, \mathrm{Na}, \mathrm{CTC}$ e saturação de bases); microbianos (observação microscópica e análise de enzimas). Os métodos aplicados incluíram regressão linear e lógica, exame de correlações, como também métodos específicos para projeção das variáveis no espaço, ou seja, dados geográficos manipulados no SIG e apresentados em forma de mapas georreferenciados demonstrando padrões semelhantes dos vários parâmetros medidos. As análises de correlação determinaram a existência de relações estatísticas significativas entre as variáveis medidas.

O estudo de Costa et al. (2000), teve como objetivo determinar as práticas de manejo a serem adotadas para a produção de Eucalyptus spp., a partir da análise dos atributos que expressam a produtividade da cultura, como as características físicas, químicas e mineralógicas dos solos, além dos atributos edáficos. A determinação dos principais atributos que indicam o índice de sítio, foi efetuada por meio da análise de agrupamentos (cluster). Foram gerados modelos matemáticos, utilizando regressões 
múltiplas, para estimar as produções futuras. Os critérios adotados para identificação das unidades de manejo, foram obtidos por meio de análises estatísticas, levando-se em conta: clima (precipitação anual, capacidade de armazenamento de água no solo, déficit hídrico); estrutura do solo (teor de argila, relação areia/argila, capacidade de retenção de umidade); estado nutricional do solo (teores de P, K, Ca; características do solo - CTC, nível de saturação de bases); produtividade da área (IMA). O trabalho foi desenvolvido na Champion Papel e Celulose Ltda, abrangendo as regiões de Brotas, São Simão e Mogi-Guaçu, situadas no estado de São Paulo. Foram realizadas análises químicas e físicas dos solos, para posterior elaboração de um mapa digital dos solos. Dados de índice de sítio, incremento médio anual da floresta (IMA) e balanço hídrico, foram utilizados na complementação do banco de dados, para posterior elaboração dos mapas de ambientes de produção. Para geração das análises estatísticas, foi utilizado o programa SAS 8.12 (Statistical Analysis System), que determinou quais atributos exercem maior influência na determinação da produção florestal, além da construção de modelos estatísticos preconizando a produção. Após análise dos dados, foram gerados no programa Geomedia Professional V3.00-Intergraph Corporation, mapas por meio de análises espaciais de todos os atributos que apresentaram similaridade (análise de "cluster"), visando determinar os ambientes de produção. Os benefícios que proporcionaram esta redefinição, foram: estimativas de produção para cada área da empresa; melhor dimensionamento de medidas corretivas do solo (otimização das adubações); estimativa para o plantio das espécies florestais que são mais aptas para cada área; adoção de medidas que aprimorem a conservação dos solos (compactação e carreamento das partículas); monitoramento sistemático da exportação/ciclagem de nutrientes do solo durante o processo de colheita florestal.

O trabalho de Bierwagen et al. (2000), discute as etapas e as necessidades emergentes na implantação de um sistema de gestão gerencial da informação florestal, na Eucatex S.A, em 3 principais fontes de informações florestais: inventário, cadastro e cartografia. O SIG TNTmips foi capaz de organizar e disponibilizar tal volume de informações de forma ágil, acessível e inteligente, para apoio à tomada de decisões gerenciais, visando à manutenção da sustentabilidade produtiva de extensos maciços 
florestais distribuídos em diversas localidades, com condições climáticas, topográficas e pedológicas diversificadas. Entre os usos deste sistema na empresa Eucatex está a determinação da produtividade florestal dentro de cada fazenda, assim como o levantamento e monitoramento de solo e clima.

Venturi (2000) descreve as principais etapas utilizadas para a estruturação e utilização do SIG pela Klabin, citando exemplos aplicados ao planejamento e produção florestal. Como o levantamento pedológico de uma área descontínua de 114.000ha. Para tanto foram coletadas amostras de 5.998 pontos, identificando-se 8 classes de solos e estabelecidas 40 unidades de mapeamento. Para aplicar o mapeamento de solos e as unidades de manejo à área florestal, foram considerados 5 fatores subdivididos em 3 classes ou graus: classe de produtividade florestal (alta, média ou baixa). Foram analisadas classes de sítio (altura média dominante aos 15 anos), IMA e tipos de solo; classe de limitação por deficiência de fertilidade (alta, média ou baixa) - $\mathrm{Ca}, \mathrm{Mg}$ e K ; classe de limitação por impedimento a mecanização no período seco (nulo, moderado, forte), analisando-se a estrutura do relevo e grau de declividade; Classe de limitação por impedimento a mecanização no período chuvoso (nulo, moderado, forte), analisando-se estrutura de relevo, declividade e grau de drenagem; classe de limitação por susceptibilidade a erosão (nulo, moderado, forte). Foram considerados ainda dados sobre temperaturas, evapotranspiração potencial, precipitação pluviométrica, dentre outros. Após a coleta e análise destas informações foram gerados mapas de acordo com as classes mencionadas acima, além da estruturação do banco de dados. A utilização destes dados em um SIG contribui na integração das atividades florestais ao meio físico, permitindo o planejamento direcionado para um determinado tipo de solo, localizado em condições de declividade e relevo específicos, sob condições climáticas diversas. Possibilita ainda o rápido direcionamento da exploração e transporte florestal para áreas com menos susceptibilidade a erosão e compactação de solo, em períodos chuvosos. Por meio do cruzamento dos mapas de vegetação primária com o mapa de solos e o mapa de talhões criou-se o tema solos - vegetação - talhão. Foram analisados e processados os dados referentes à fertilidade, susceptibilidade à erosão e declividade, por meio do programa SAS. Além da utilização destas informações para auxílio ao planejamento, a 
Klabin está gerando relatórios para aptidão ao plantio de eucalipto, considerando-se as variáveis fertilidade, geada de acúmulo, geada de vento etc.

Na pesquisa de Thwaites \& Slater (2000), foram estudadas, dentro da Floresta Estadual de Benarkin no sudeste e norte de Queensland, as relações entre os atributos químicos e físicos do solo, do relevo e microclima dentro de um SIG, utilizando análise exploratória dos dados, lógica fuzzy e MDT, para o gerenciamento de florestas, classificação de sítios e ajuste de modelos para estimar a qualidade de sítio por meio de variáveis ambientais. Segundo os autores por meio do MDT pode-se predizer a variação da pedogeomorfologia; e a litologia é um dos fatores que atuam de forma indireta na definição da qualidade do sítio, uma vez que determinam a textura, estrutura, umidade, profundidade e outros atributos do solo. Outro fator importante é o $\mathrm{pH}$ e a morfologia do solo.

O estudo de Oliveira-Filho et al. (2000), mostrou a integração das ferramentas de topografia, cartografia digital, GPS, sensoriamento remoto e técnicas de simulação da produção florestal, voltadas para a implementação de um banco de dados geográfico baseado no modelo de dados orientado ao objeto. Foram alvo deste estudo, duas empresas florestais totalmente distintas em suas concepções de trabalho, sendo implementados dois sistemas diferenciados com a mesma finalidade básica: proporcionar suporte administrativo por meio da integração das diversas ferramentas mencionadas, além do uso de análises e visualização espacial das áreas de estudo.

\subsubsection{Aplicação da geoestatística e do geoprocessamento na área agrícola}

Nesse tópico são apresentados estudos envolvendo a aplicação da geoestatística e do geoprocessamento na agricultura, principalmente Agricultura de Precisão, com métodos análogos aos empregados no presente trabalho.

Albuquerque et al. (1996) tiveram como objetivo determinar e quantificar a variabilidade espacial da espessura do horizonte A, teor de argila, altura das plantas e produtividade de grãos de milho, assim como quantificar as relações entre estas variáveis 
e mapear a área experimental quanto à espessur a do horizonte $\mathrm{A}$ e ao teor de argila. $\mathrm{O}$ estudo foi realizado no município de Santa Maria (RS) em uma área com 6,25ha, onde foi locada uma grade amostral de $10 \mathrm{~m} \times 10 \mathrm{~m}$, sendo que em cada ponto da grade foi determinada a espessura do solo no horizonte A e efetuada a coletada de amostras de solo na profundidade de $0-20 \mathrm{~cm}$. Nestes pontos também foi obtida a altura de três plantas, sendo a variável altura da planta representada pela média aritmética destas três e, finalizando, em cada ponto foi colhida uma parcela de $9 \mathrm{~m}^{2}$ para determinação da produtividade. Utilizou a estatística, com o resumo estatístico e análise de regressão linear, e a geoestatística para análise da variabilidade espacial das variáveis estudada, com ajuste de modelos matemáticos aos semivariogramas por meio do programa SAS, tendo como parâmetros o $\mathrm{R}^{2}$ e a $\mathrm{SQR}$ de cada modelo, e interpolação por krigagem em blocos. Todas as variáveis apresentaram distribuição normal e o modelo esférico apresentou o melhor ajuste para os semivariogramas. Não foi verificada relação entre altura da planta e demais variáveis, porém observou-se relação direta entre produtividade de grãos de milho e espessura do horizonte $A\left(R^{2}=37 \%\right)$, possivelmente pela restrição ao crescimento radicular no horizonte $\mathrm{B}_{\mathrm{t}}$.

O trabalho de Salviano (1996) e Salviano et al. (1998), tiveram como objetivo caracterizar o comportamento de atributos de crotalária (Crotalaria juncea L.) e de solo, em área erodida, e relacioná-los utilizando ferramentas da estatística clássica e da geoestatística. O trabalho foi desenvolvido no município de Piracicaba (SP), numa área que vem sendo explorada com cana-de-açúcar há mais de 30 anos e onde já se visualizam sulcos de erosão. A área experimental, de 50m x 70m, foi amostrada para todos os atributos de acordo com uma malha de $5 \mathrm{~m}$ x $5 \mathrm{~m}$, totalizando 140 pontos amostrados. Foram avaliados atributos de fertilidade e de textura nas camadas de 0-20 cm e de 20-40, espessura do solo e produtividade e altura da crotalária. Foram realizadas análise descritiva e geoestatística dos dados, assim como análise de correlação e regressão linear simples e múltipla entre os dados observados. Todos os atributos apresentaram dependência espacial, com exceção do $\mathrm{P}$ subsuperficial e do $\mathrm{K}$ superficial $\mathrm{e}$ subsuperficial, sendo a maior parte deles ajustado ao modelo esférico. Os semivariogramas foram escalonados para facilitar a comparação entre eles. O 
mapeamento dos atributos usando a técnica de krigagem permitiu dividir a área em cinco classes de menor variabilidade, as quais foram consideradas como zonas de manejo. Essas zonas de manejo permitiram entender melhor os efeitos da erosão sobre a produtividade da crotalária. Os parâmetros derivados do $\mathrm{H}+\mathrm{Al}(\mathrm{r}=-0,52$ para superfície e -0.48 para subsuperfície) foram os que tiveram a mais estreita relação com a produtividade da crotalária, respondendo por $33 \%$ e $30 \%\left(\mathrm{R}^{2}\right)$, respectivamente, da variação da altura da planta, e por $29 \%$ e $28 \%$, da variação da produção de matéria seca pela planta, destacando-se a necessidade de calagem. $\mathrm{O}$ melhor modelo atingido para explicar a variação na produção de matéria seca da planta atingiu um $\mathrm{R}^{2}$ de $43 \%$ contando com as variáveis $\mathrm{H}+\mathrm{Al}$ e argila superficial, espessura do solo e silte subsuperficial. A espessura do solo, quando superior a $60 \mathrm{~cm}$ não afetou diretamente a produtividade da crotalária, mas quando essa era menor que $20 \mathrm{~cm}$, afetou-a fortemente.

Camargo (1997) realizou um estudo geoestatístico, com emprego do SIG Spring, na Fazenda Canchim, município de São Carlos (SP). Foram coletadas amostras de solo para determinação da textura, posteriormente foram realizados o resumo estatístico e a análise exploratória dos dados, ajuste dos semivariogramas experimentais para cada classe (arenoso, médio argiloso, argiloso, muito argiloso) deste atributo do solo, validação do modelo, finalizando com a interpolação dos dados amostrais a partir do método da krigagem ordinária e apresentação em mapas de contorno.

Os artigos de Balastreire et al. (1997) e Balastreire (1998), relatam o desenvolvimento, construção e uso de um sistema de instrumentação e aquisição de dados georreferenciados a partir do uso de GPS, para o mapeamento, no programa Surfer 5.0, da produtividade da cultura de milho em uma área com 7 ha. Verificou que 47,8\% das células de 10,8m de comprimento e 3,6m de largura, possuíam produtividade na faixa de 3,59 a 4,76 t/ha, para uma produtividade média da cultura de 3,84 t/ha. Foram aplicadas técnicas de interpolação pelo método de krigagem e interpolação pelo método do quadrado inverso da distância ("Inverse Squared Interpolation"), para elaboração de mapas representando linhas de iso-produtividade. O mapa de produtividade permitiu a detecção da variabilidade espacial da produtividade da cultura de milho, e conseqüente gerenciamento localizado desta cultura, otimizando a utilização dos insumos e obtenção 
da máxima produtividade. Concluí que o princípio aplicado pode ser adaptado para o mapeamento da produtividade de culturas onde sistemas de medição de fluxo de massa não possam ser utilizados e que o programa utilizado para a elaboração do mapa de produtividade mostrou-se adequado, possibilitando a detecção da variabilidade espacial da produtividade .

Rocha \& Lamparelli (1998) relatam um experimento realizado no município de Mineiros (GO), em uma área com 8ha, onde foram gerados mapas digitais de produtividade e de diferentes atributos do solo, por meio de interpolação digital no programa Idrisi for Windows 2.0 (método do inverso do quadrado da distância). O georreferenciamento, com base nos dados coletados por meio do GPS, permitiu a análise, por meio de operações algébricas disponíveis no SIG, do mapa de rendimento da colheita do milho "safrinha", em uma faixa de talhão com 8ha, assim como sua comparação com mapas de atributos do solo (fertilidade e granulometria).

Sudduth et al. (1998) usaram dados coletados em um campo com 36 ha no Missouri Central para investigar métodos de análise estatística e modelagem do crescimento de colheita que relacionem, no espaço, rendimentos de grãos e atributos que podem afetar o rendimento. Foram coletados dados de rendimento em 1993 (milho), 1994 (feijão-soja), 1995 (sorgo de grão), 1996 (feijão-soja) e 1997 (milho). Foram gerados mapas georreferenciados do rendimento, atributos de fertilidade do solo na camada de 0-20 cm e topografia (declividade e elevação) a partir de grades com $30 \mathrm{~m}^{2}$ área. Foram ajustados modelos matemáticos aos semivariogramas e posteriormente os parâmetros destes foram utilizados para a interpolação dos dados observados por meio do método de krigagem. Foi realizada análise de regressão para estimava e modelagem dos rendimentos em função de dados de solo e topográficos. Os resultados obtidos não puderam predizer o rendimento para os anos futuros e estratégias de administração, devido às incertezas associadas com o rendimento de cada ano analisado, que estão muito relacionadas as diferentes condições climáticas nos anos analisados. O modelo de crescimento da colheita teve pouco êxito na representação da variabilidade espacial do rendimento. Em uma tentativa para superar esta limitação, foram desenvolvidos métodos para responder a redistribuição de água baseado em características do solo e topografia. 
Franco et al. (1998) realizaram a avaliação técnica do tipo de solo e da topografia de uma lavoura de cana-de-açúcar, com o objetivo de a tornar apta para a colheita mecanizada a partir da melhora da disposição espacial das áreas propícias ao cultivo. Utilizaram GPS para mapeamento planialtimétrico e registro da posição espacial das amostras de solo coletadas. Dentro do SIG TNTmips foram gerados (interpolação pelo método do inverso da distância ao quadrado) e integrados mapas de classes de declive, mapas de solos, teor de argila, altimetria, índice de produção relativa e mapas cadastrais da situação atual da área de produção. Com a análise interpretativa desses mapas e dados, foram gerados no SIG novos modelos de plantio e terraceamento, que posteriormente foram implantados no campo. É esperado que esse novo modelo de sistematização de áreas para colheita mecanizada, aumente a área disponível para o plantio, otimize o uso de máquinas e reduza em grande parte o custo da colheita, refletindo uma melhor na eficiência e na produtividade das empresas sucro-alcooleiras.

Vieira et al. (1998) e (2000) com base em dados de produção de culturas muais, sob plantio direto, em três municípios do Estado de São Paulo, sendo uma área com 4ha e as outras duas com 1ha, avaliaram a variabilidade espacial dos atributos das culturas e do solo, assim como relacionaram a variabilidade dos atributos de solo entre si e com os dos atributos das culturas em áreas de agricultura intensiva, a partir de análise estatística descritiva e análise geoestatística (semivariograma e krigagem). A análise geoestatística foi empregada para determinar a dependência espacial dos atributos dos solos e da planta, por meio de semivariograma. A técnica de krigagem foi utilizada para a construção de mapas de isolinhas. Todas as variáveis estudadas apresentaram dependência espacial, com destaque para o carbono e sódio. Concluíram que a variabilidade dos teores de carbono e sódio é extremamente contínua, com o uso de semivariograma esférico. A variabilidade dos parâmetros ligados à textura do solo é bastante grande e não se agrupa bem em um semivariograma escalonado. A variabilidade dos parâmetros ligados à permeabilidade do solo está relacionada à variabilidade da espessura do solo.

Jakob et al. (1999) estudaram e avaliaram uma metodologia para análise da variabilidade espacial de atributos do solo e sua correlação com o rendimento da cultura de milho. Para isto, foram utilizadas técnicas de estatística básica (programa SAS 
System) para a análise estatística e exploratória dos dados; geoestatística (programa Variowin 2.0) para ajuste de semivariogramas e definição dos parâmetros da krigagem; geoprocessamento (programa Surfer 6.0 e Idrisi for Windows 2.0) para a criação de mapas interpolados de atributos do solo e rendimento da cultura, assim como efetuar a regressão espacial entre mapas. $\mathrm{O}$ ensaio foi realizado numa área de aproximadamente 4ha, em Paulínia (SP). Os mapas de atributos interpolados foram correlacionados com o mapa interpolado de rendimento de cultura, sendo que os resultados mostraram que o modelo obtido com os atributos mais importantes para a produção do milho explicou $82 \%$ do rendimento da cultura, utilizando como parâmetros os índices de $\mathrm{MO}, \mathrm{Mg}$, Argila, $\mathrm{P}, \mathrm{Ca}, \mathrm{K}$ e H+Al. Concluíram que o Surfer foi um bom auxílio para a criação de "grids" de interpolação, por possibilitar a entrada do melhor ajuste de modelo, possibilitando o controle do efeito pepita, o patamar e o alcance de cada mapa a ser criado. O Idrisi também se mostrou adequado para as análises de regressões realizadas, uma vez que as realiza sem a perda da posição espacial dos dados, ou seja, pixel-a-pixel, sendo mais adequado se comparado aos programas de estatística convencionais, como o SAS, que não considera a posição espacial dos dados e modifica a posição dos limites dos atributos do solo.

Pagnano \& Magalhães (1999) construíram um mapa digital do rendimento produtivo, para cana-de-açúcar, no programa Idrisi for Windows 2.0, com base na coleta automática de dados georreferenciados por GPS. Estes dados foram interpolados, utilizando técnicas de geoestatística (krigagem), o que permitiu a geração de um mapa digital representando uma superfície contínua de produção para a área colhida, possibilitando identificar áreas com maior e menor produtividade.

Marques Junior et al. (2000) avaliaram a variabilidade espacial dos atributos granulométricos e químicos dos solos e da produção de café em diferentes superfícies geomórficas sobre solos altamente intemperizados, no município de Patrocínio (MG). Numa superfície plana, duas subáreas foram escolhidas e diferenciadas de acordo com critérios de separação de superfícies geomórficas. Em cada subárea foi instalada uma parcela de $200 \mathrm{~m}$ x $850 \mathrm{~m}$, dividida numa malha com espaçamento regular de $50 \mathrm{~m}$ entre os pontos, resultando 68 pontos para cada malha. Os solos foram amostrados em duas 
profundidades $(0-20 \mathrm{~cm}$ e $60-80 \mathrm{~cm})$, posteriormente as amostras foram submetidas a análises químicas e granulométricas. A variabilidade do solo foi inicialmente avaliada por estatística simples. A análise da dependência espacial foi feita por meio de geoestatística, por meio de ajuste de semivariogramas, pressupondo a suposição da hipótese intrínseca. Os resultados apontaram que os valores do coeficiente de variação dos parâmetros granulométricos, são menores que os químicos e que todos os semivariogramas construídos ajustaram-se bem ao modelo esférico, o mais adaptado para descrever o comportamento de semivariogramas de atributos de solo e de plantas. Concluem que o comportamento das plantas acompanha a distribuição e variação dos nutrientes no solo, que os atributos químicos e granulométricos possuem dependência do relevo, mesmo de pequena expressão e em solos altamente intemperizados e manejados quimicamente e que o atributo produção de café apresentou dependência espacial forte em ambas superfícies e, alcance maior na superfície geomórfica mais plana.

Pierossi \& Neves (2000) mapearam a variabilidade espacial da produtividade da cana-de-açúcar, no âmbito da agricultura de precisão, em duas áreas, uma com 1,4ha e outra com 1,8ha, pertencentes à Usina São Martinho localizada no município de Pradópolis-SP. Para tanto foi utilizado GPS em uma colhedora que operou ao lado de um caminhão com caçamba instrumentada, para pesagem dos experimentos. Os valores de produtividade, para cada ponto amostrado foram colocados em um histograma, para visualização da distribuição desses valores de produtividade. Os resultados mostraram grandes variabilidades dentro dos talhões, com valores de produtividade oscilando de 20 a 140 ton/ha.

Torres \& Prochnow (2000) descrevem uma metodologia de agricultura de precisão, utilizada para a elaboração de mapas de fertilidade do solo para detecção da variabilidade e dos atributos relacionados à produção e variação do citrus, assim como apresentam um exemplo de mapeamento realizado em uma gleba de terra com 30 ha, da Fazenda Muriti. Foram coletadas amostras de solos, a cada hectare, e georreferenciadas com GPS e posteriormente foram analisadas quimicamente $(\mathrm{P}, \mathrm{K}, \mathrm{Ca}, \mathrm{Mg}, \mathrm{S}, \mathrm{B}, \mathrm{Zn}, \mathrm{S}$, $\mathrm{Fe}, \mathrm{Al}, \mathrm{Mn}, \mathrm{Cu}$, matéria orgânica, $\mathrm{pH}, \mathrm{CaCl}$, soma de bases e $\mathrm{V} \%$ ) em laboratório. Concluem que os equipamentos e técnicas adotadas mostraram-se adequados, porém 
alertam quanto a quantificação ideal das amostras, do raio de retirada das subamostras e o local, dentro da grade de amostragem.

Borghi et al. (2000) compararam dois procedimentos de processamento e integração de dados, visando compor um modelo matemático que explique a variabilidade espacial da produtividade da cultura de milho, em função de parâmetros do solo, em uma área experimental com 4ha. Foi montada uma grade de amostras espaçadas por $25 \mathrm{~m}$ e georreferenciadas com 48 pontos, onde foram coletadas amostras de solo e onde foi mediada a produtividade do milho. Foram levantados os seguintes parâmetros do solo: $\mathrm{P}, \mathrm{K}, \mathrm{Ca}, \mathrm{Cu}, \mathrm{Mg}, \mathrm{S}, \mathrm{B}, \mathrm{Zn}, \mathrm{Fe}, \mathrm{H}+\mathrm{Al}, \mathrm{Mn}$, percentagem de areia, de silte e de argila, $\mathrm{Cu}$, matéria orgânica, $\mathrm{pH}, \mathrm{CaCb}$, soma de bases e $\mathrm{V} \%$ ). Dois modelos, a partir de regressão múltipla, foram gerados, com base nos principais parâmetros analisados. O primeiro utilizou mapas interpolados, confeccionados a partir de técnicas de geoestatística, como a krigagem, obtendo um mapa de produtividade estimada; e o segundo somente os pontos amostrais, obtendo uma estimativa pontual de produtividade e interpolando o resultado final. Os resultados mostram que o modelo ajustado por meio dos mapas interpolados apresenta um coeficiente de determinação maior, aparentemente mostrando melhores resultados.

Vieira (2000) avaliaram a variabilidade espacial da produtividade do milho "safrinha" em Campos Novos Paulista. Foi locada uma grade com 92 pontos com espaçamento de $50 \mathrm{~m}$ x $50 \mathrm{~m}$. De cada ponto foi retirada amostras para análise da fertilidade do solo nas profundidades $0-20 \mathrm{~cm}, 20-40 \mathrm{~cm}, 40-60 \mathrm{~cm}$ e $60-100 \mathrm{~cm}$. Posteriormente foram comparados três métodos para interpolação e elaboração dos mapas dos atributos estudados: krigagem, a partir dos parâmetros dos semivariogramas de cada variável; krigagem, a partir do semivariograma linear padrão e por último o inverso do quadrado da distância. O resultado foi a obtenção de mapas diferentes, com áreas de diferente potencial de produtividade, indicando áreas de baixo, médio e alto valor das variáveis medidas.

O trabalho de Silva Junior (2001), teve como objetivo explorar a variabilidade espacial do índice de cone (IC) por meio de análises geoestatísticas, e correlacioná-la com mapas de produtividade. Duas áreas com sistema de semeadura direta foram 
utilizadas no experimento, uma no município de Pirassununga (SP), com 19ha, e a outra no município de Castro (PR), com 24ha. Mapas do índice de cone das profundidades de 0,$10 ; 0,15 ; 0,20 ; 0,25 ; 0,30 ; 0,35$ e $0,40 \mathrm{~m}$ foram gerados e correlacionados com mapas de produtividade. Para tanto, foi utilizado um penetrômetro de cone hidraúlico-eletrônico, posicionado por DGPS (Sistema de Posicionamento Global Diferencial), com correção diferencial em tempo eal via satélite, sendo as informações processadas por um SIG. Foi efetuada a análise descritiva dos dados seguida pela análise geoestatística. Com o objetivo de identificar a estrutura de dependência espacial foram construídos semivariogramas isotrópicos e anisotrópicos, no programa GS+, de todas as variáveis estudadas, aceitando a hipótese intrínseca e posteriormente sobre o conjunto de dados foi aplicada a krigagem ordinária. Os mapas interpolados foram importados e apresentados no SIG SSTOOLBOX. Utilizando os dados estimados pela krigagem, em tabela, foi realizada análise de regressão linear simples entre o índice de cone em todas as profundidades e a produtividade. Todas as profundidades analisadas apresentaram estrutura de dependência espacial nas duas áreas. Observoutse o efeito do teor de água do solo sobre o índice de cone. A análise de regressão entre as produtividades e o índice de cone apresentou baixos coeficientes de determinação, sendo o maior $\mathrm{R}^{2}$ atingido na relação entre produtividade do milho e IC na profundidade $0-10 \mathrm{~cm}$, em Castro igual a $15 \%$ e em Pirassununga igual a $11 \%$. Na área de Castro houve tendência de redução da produtividade do milho e da soja com o aumento do índice de cone em todas as profundidades. Os mapas do índice de cone do solo, gerados por meio do sistema penetrômetro de cone hidraúlico-eletrônico, GPS, SIG e programas computacionais geoestatísticos, mostraram a variabilidade do índice de cone existente entre as regiões representadas pelos diversos pontos amostrais levantados. 


\section{MATERIAL E MÉTODOS}

\subsection{Material}

\subsubsection{Caracterização da área de estudo}

O experimento foi conduzido no talhão 06 (Figura 3), gleba G-09C, Fazenda Cachoeirinha, Regional Leste, pertencente à Suzano Bahia Sul Celulose, município de Paraibuna, Vale do Paraíba, SP. A área total do talhão 06 é de 33,42ha, sendo 23,39ha (70\%) composto pelo clone G24 e 10,02ha (30\%) pelo clone G319. Foi delimitada uma área de 8,4ha (Figura 4), entre as coordenadas UTM 427558E, 427921E, 7398360N e $7398770 \mathrm{~N}$, fuso 23 , meridiano central $45^{\circ}$, ocupada apenas pelo clone G-24 para instalação do experimento, visando a uma menor variabilidade do ponto de vista biológico. Tanto o clone G24, como o G319 são híbridos da espécie E. grandis Hill ex Maiden, plantados em 01/03/1996, em sua primeira rotação, com espaçamento de 2,7 m x $2,2 \mathrm{~m}$. 


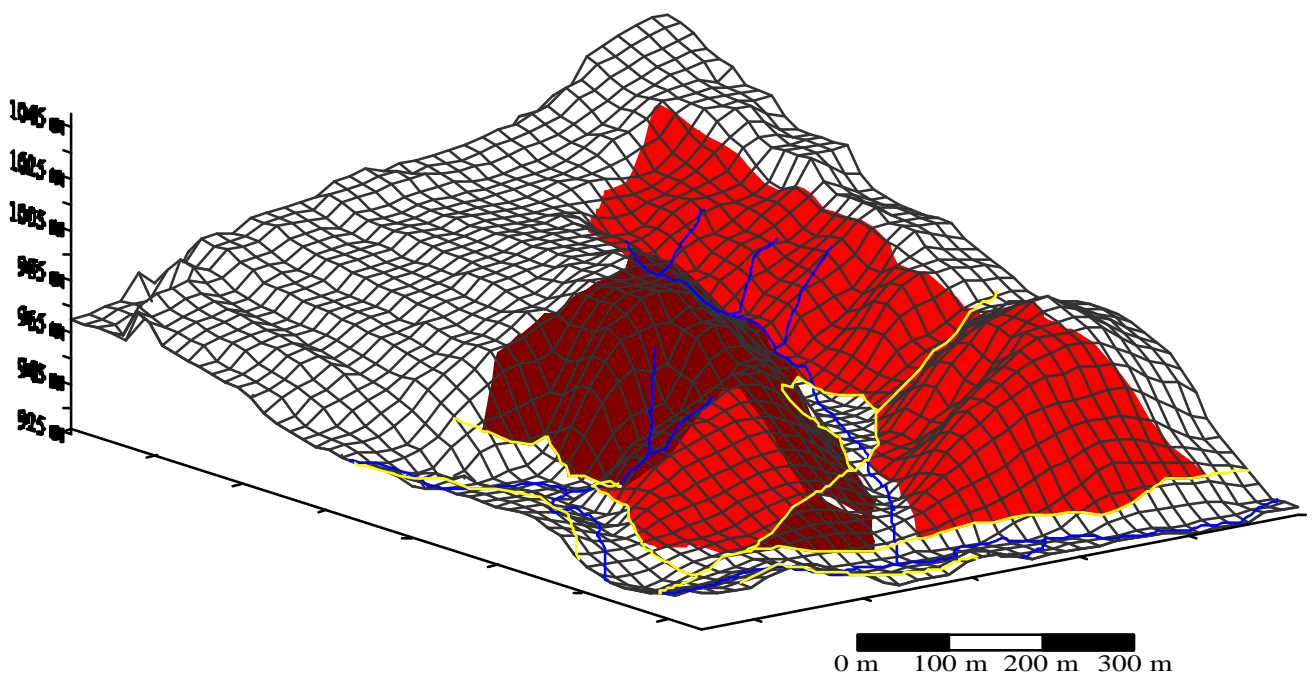

Município: Paraibuna/SP

Local: Gleba G9C Talhão 06

Área total: 33,42ha

Espécie: Eucalyptus grandis (clone 24 e clone 319 )

$1^{\circ}$ Rotação

Data de plantio: 01/03/1996

Espaçamento: $2,7 \mathrm{~m} \times 2,2 \mathrm{~m}$

Área Clone 24 (23,39ha)

Área clone 319 (10,02ha)

Carreadores

Cursos d' água

Figura 3 - Area do talhão 06

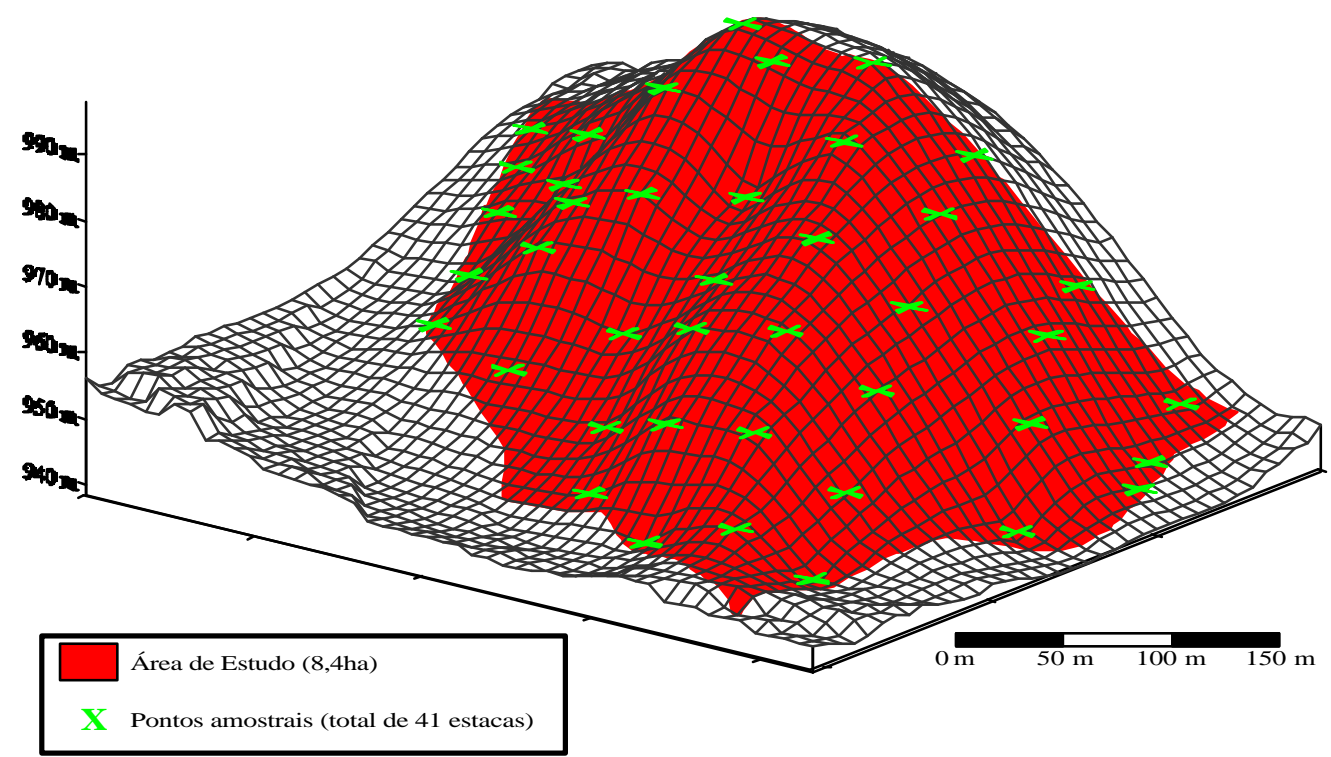

Figura 4 - Área de estudo 
A área do experimento é heterogênea em relação ao relevo, sendo este acidentado e com diferença de nível acentuada, e aos atributos do solo, tanto os físicos como os químicos. Também é heterogênea em relação ao potencial produtivo, visto que há uma nítida variação na altura das árvores, em função da posição topográfica, isto é, as árvores aumentam em tamanho àmedida que ocupam cotas menores nas encostas.

Com relação à adubação foram aplicados $75 \mathrm{Kg} \cdot \mathrm{ha}^{-1}$ da fórmula 20-00-20 e 180Kg.ha ${ }^{-1}$ de Super Fosfato Triplo antes do plantio, não tido sido efetuada adubação de manutenção. Foram realizados outros tratos culturais, como roçada de pré-manutenção, capina química e combate à formiga com o Formicida granulado K-otrine.

Até o presente momento o talhão apresenta o seguinte histórico (Tabela1):

Tabela 1. Histórico do talhão

\begin{tabular}{ccccc}
\hline Data & Atividade & Rotação & Espécie & Espaçamento (m) \\
\hline $01 / 12 / 1971$ & Plantio & $1^{\underline{a}}$ & E. saligna & $2,00 \times 2,00$ \\
$01 / 05 / 1988$ & Corte & $2^{\underline{a}}$ & E. saligna & $2,00 \times 2,00$ \\
$01 / 09 / 1995$ & Corte & $3^{\underline{a}}$ & E. saligna & $2,00 \times 2,00$ \\
$01 / 03 / 1996$ & Plantio & $1^{-}$ & E. grandis & $2,70 \times 2,20$ \\
$01 / 03 / 2003$ & Corte & $1^{\text {a }}$ & E. grandis & $2,70 \times 2,20$ \\
\hline
\end{tabular}

Fonte: Suzano Bahia Sul Celulose.

O clima da região enquadra-se na classificação de Köppen como do tipo "Cfa", com temperatura média do mês mais frio inferior a $18^{\circ} \mathrm{C}$ e do mês mais quente superior a $22^{\circ} \mathrm{C}$ (Veiga, 1985). Na região, a precipitação pluviométrica média entre os anos de 1986 a 1996 foi de $1.469 \mathrm{~mm}$, enquanto que para o ano de 2002 foi de $1.316 \mathrm{~mm}$ na área da Fazenda Cachoeirinha. A estação seca ocorre entre os meses de abril e setembro, sendo que os meses de junho, julho e agosto são os de menor precipitação pluviométrica e também os mais frios (Figura 5). Entre os meses de outubro e março ocorre o período mais intenso de chuvas, sendo os meses de janeiro e fevereiro os mais chuvosos e mais quentes (Figura 5). 
$\square$ Precipitação média no período $\bullet-$ Temperatura média no período

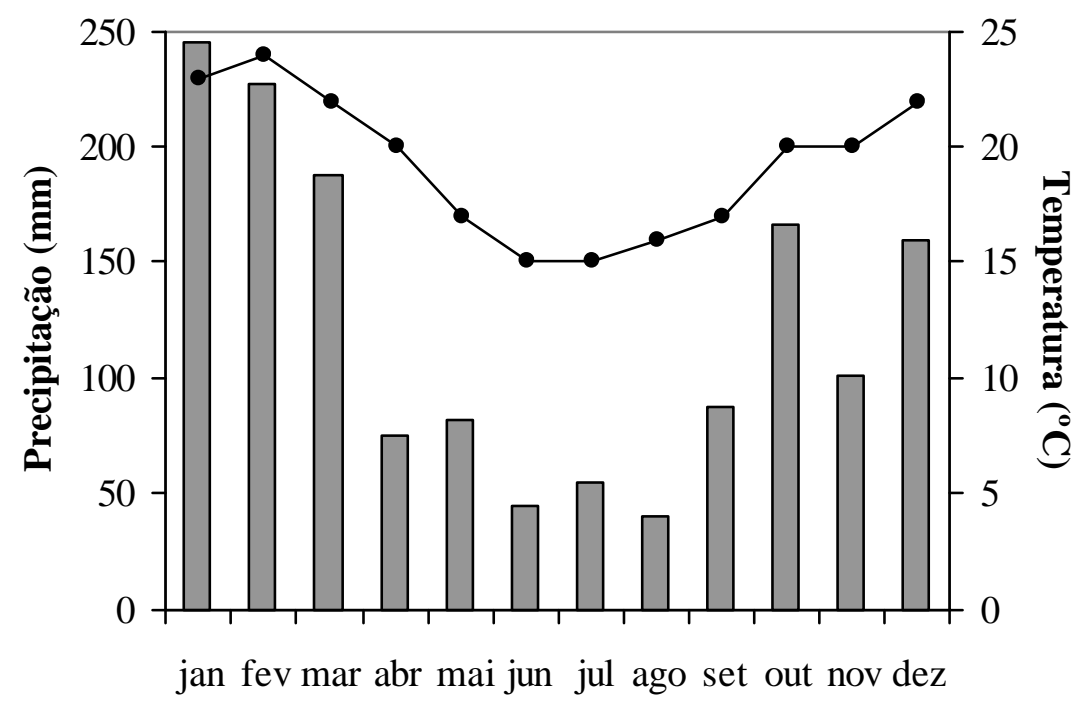

Período (mês)

Figura 5 - Precipitação pluviométrica e temperaturas médias no período de 1986 a 1996 no município de Paraibuna (SP)

Fonte: Companhia Suzano de Papel e Celulose (1997) apud Dário (1999).

A área de estudo caracteriza-se geomorfologicamente como uma região de terras altas (Monbeig, 1949), com relevo de "mar de morros", com topos arredondados, vertentes com perfis retilíneos e convexos, o denominado "Relevo de Morros Paralelos" e longas serras longitudinais (Almeida, 1964). A Fazenda Cachoeirinha, onde foi desenvolvido o presente estudo, está localizada na Serra do Mar, com altitude variando de 944m a 1.136m (Instituto de Pesquisas Tecnológicas, 1981a), com predomínio de rochas do tipo granito-gnáissico (IPT, 1981b). Estas rochas possuem uma granulação fina e média, composição granítica a granodiorítica e ocorrência conspícua de megacristais de feldspato potássico (Brasil, 1960). O solo predominante na região é o PV - Argissolo Vermelho intergrade para Latossolo Vermelho Distrófico $\mathrm{Tb}$ A moderado, textura média/argilosa. 


\subsubsection{Equipamentos}

Foram utilizados na realização deste trabalho os seguintes equipamentos:

- estação total PENTAX / R-115N, que possui luneta com aproximação de 30 X, círculos vertical e horizontal graduados em graus, com leitura digital de 1" e medidor eletrônico de distância (infravermelho) com alcance de até 4,0km em condições atmosféricas normais e operando com 3 prismas, com precisão angular de 5" e precisão linear de $\pm 5 \mathrm{~mm}+3 \mathrm{ppm}$;

- acessórios para levantamento topográfico: prismas, balizas, trena;

- trado, dendrômetro de Blume-Leiss e suta de alumínio.

\subsubsection{Mapas e programas}

- mapas topográficos e de talhonamento, nas extensões dxf e dwg;

- sistemas computacionais relacionados a cartografia digital (AutoCAD R14), geoestatística (GS+ - "Geostatistics for the Environmental Sciences" e Geoeas "Geostatistical Environmental Assessment Software"), sistemas de informação geográfica (Idrisi32 e Surfer 6.0) e estatística (SAS 6.12, Statistica e Excel).

No AutoCAD R14 (Autodesk, 1998) foram manipuladas as informações referentes aos mapas de talhonamento e topográfico do talhão 06, na extensão dwg, cedidos pela Cia Suzano de Papel e Celulose, e incorporadas as informações coletadas durante o trabalho de topografia e de instalação da grade amostral na área de estudo, posteriormente exportadas para o Idrisi e Surfer na extensão dxf.

Com os programas Excel (Microsoft Corporation, 1998), SAS (SAS Institute, 1993) e Statistica (Statsoft, 1993) foi realizada a análise estatística descritiva dos dados, para visualizar o comportamento geral dos dados e identificar possíveis valores discrepantes.

Os programas Excel, SAS, Statistica e Surfer (Golden Software, 1995) foram usados para a análise exploratória dos dados, com o objetivo de identificar possíveis 
valores discrepantes, verificar e descrever as medidas estatísticas e matemáticas dos dados e auxiliar na decisão das hipóteses de estacionaridade que podem ser assumidas.

Com o programa Statistica foram efetuadas as análises de correlação entre a variáveis estudadas, e no SAS as análises de regressão linear simples e múltipla entre a variável dependente (IS) e as independentes.

No GS+ (Gamma Design Software, 1998) foram ajustados semivariogramas para análise do grau de dependência espacial entre as amostras, e definidos os parâmetros necessários para a estimativa de valores para locais não amostrados. Nesse programa também foi realizado o escalonamento dos semivariogramas pela variância.

Dentro do programa Geoeas (Englund \& Sparks, 1991) foram realizadas a validação cruzada e a identificação do número ideal de vizinhos para a krigagem. $O$ programa Geoeas possibilita identificar o erro de estimativa da krigagem, ou seja, conhecer a qualidade e a precisão da krigagem, por meio dos diversos e eficientes parâmetros de decisão referentes à validação cruzada disponíveis no módulo X-VALID, permitindo a escolha dos semivariogramas mais adequados, com a acurácia desejada, para a krigagem.

No programa Surfer foi efetuada a interpolação por krigagem, a partir da entrada dos parâmetros definidos com o ajuste do semivariograma, resultando numa melhor e mais acurada representação, em mapas de contorno e de superfície, da distribuição espacial das variáveis na área de estudo. A criação e a edição dos mapas de contorno e de superfície no Surfer mostram-se eficientes, assim como a interface entre os arquivos gerados no Surfer, Idrisi e AutoCAD.

No Idrisi (Eastman, 1998) foram derivados do MDT os modelos de face de exposição e de declividade, editados no SIG e posteriormente inclusos nas análises espaciais.

Também no SIG Idrisi foram realizadas as análises espaciais com as variáveis estudadas, mostrando-se adequado para as análises de regressão linear simples e múltipla espacial, uma vez que realiza regressões sem a perda da posição espacial dos dados, o que não ocorre com programas de estatística convencionais, como o SAS. Porém, faltam a esse SIG procedimentos para o processo automático de redução do número de variáveis 
explicativas a serem consideradas no ajuste de modelos de regressão linear múltipla espacial, assim como a possibilidade de entrada de um maior número inicial de variáveis independentes no processo de seleção dos modelos de regressão.

\subsection{Métodos}

Diversas são as abordagens possíveis para a implementação da Silvicultura de Precisão. Nesta pesquisa foi utilizada a abordagem que se baseia, resumidamente, no mapa de potencial produtivo e na identificação dos fatores causadores da variabilidade da capacidade produtiva. Esta abordagem viabiliza-se com a tecnologia da análise espacial por meio de um sistema de informação geográfica (SIG) e da geoestatística.

O método direto (Schonau \& Purnell, 1987; Gonçalves, 1990; Braga, 1997 e Scolforo, 1997) foi aplicado para classificar as parcelas em classes de sítio, de acordo com o potencial produtivo expresso pelo índice de sítio (IS). Foi utilizado o método indireto/quantitativo (Gonçalves, 1990; Schonau \& Aldworth, 1987; Braga, 1997 e Scolforo, 1997) para estimar a capacidade produtiva do sítio florestal, que utiliza a análise fator-sítio ou solo-sítio e se baseia na locação de parcelas no povoamento florestal, abrangendo uma série de sítios com diferentes capacidades produtivas, em função das variáveis climáticas, fisiográficas e edáficas existentes na área de estudo. Este método busca estabelecer relações matemáticas entre o crescimento das árvores e os atributos do solo e do relevo, possibilitando classificar as parcelas em classes de qualidade de sítio em função do potencial de produção e das características do solo e do relevo.

\subsubsection{Instalação da grade amostral}

Foi instalada, na área experimental, uma grade irregular totalizando 41 pontos amostrais. Para a materialização dos pontos de amostra foram empregadas estacas de madeira como marcos indicativos. A instalação da grade foi realizada com emprego da estação total e de acessórios topográficos. 
Para a locação dos pontos amostrais na área de estudo fez-se uso da amostragem aleatória estratificada (Figura 6), que consiste em subdividir a área total em várias células, com área igual e usualmente quadradas, dentro das quais é feita a casualização dos pontos de amostragem. Foram utilizadas células com área total de $2.500 \mathrm{~m}^{2}(50 \mathrm{~m} \mathrm{x}$ 50m). O uso deste método de amostragem para as aplicações e propósitos deste estudo foi embasado por Reichardt et al. (1986), os quais salientam que a distância constante entre as amostras não é estritamente necessária para o uso da geoestatística, desde que a posição relativa das amostras seja conhecida, e de acordo também com o colocado por Lamparelli et al. (2001) no capítulo 2.5 (Geoestatística), onde afirmam que este método de amostragem é o ideal para a aplicação das técnicas geoestatísticas, uma vez que possui os principais benefícios dos esquemas sistemático e aleatório.

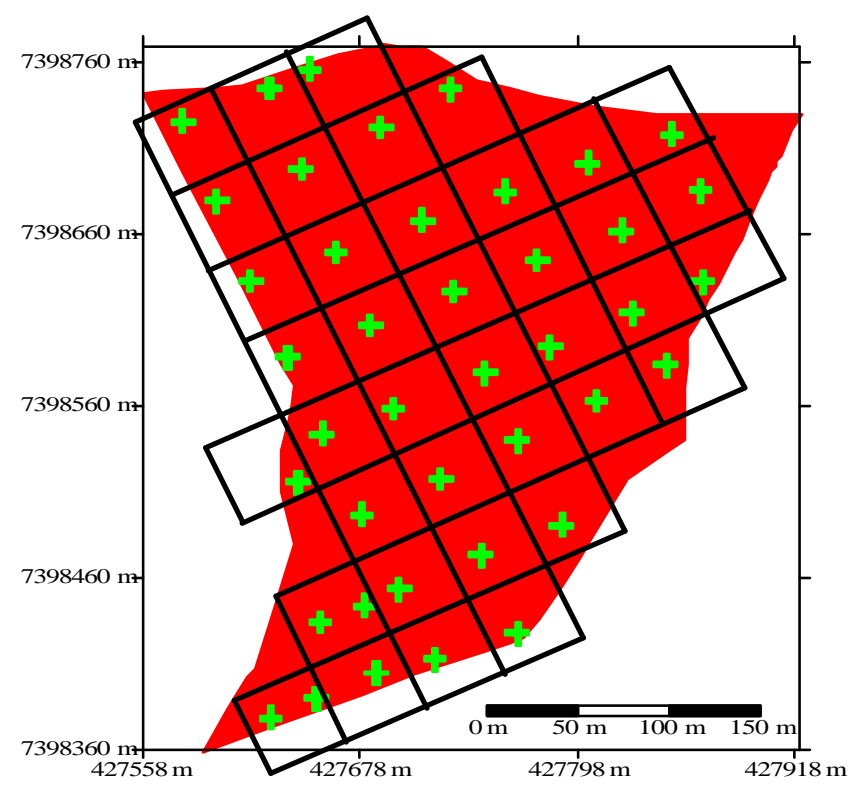

Figura 6 - Distribuição dos pontos amostrais na área de estudo

\subsubsection{Coleta e preparo dos dados}

Com o emprego da estação total e acessórios foram levantados os valores das coordenadas planas, em metros, no sistema UTM, atributos x e y de cada ponto amostral, 
bem como as cotas altimétricas (atributo z).

Posteriormente foram coletadas, com auxílio do trado, amostras compostas por 3 subamostras de solo em uma única profundidade $(0-20 \mathrm{~cm})$, para análise em laboratório de seus atributos físicos (granulometria) e químicos (macronutrientes e micronutrientes). A amostragem de solos, em áreas plantadas com Eucalyptus sp., na camada mais superficial do solo é sugerida por Barros et al. (1986), Gonçalves et al. (1990) e Melo (1994) para análise das variações nos teores dos nutrientes na planta e, conseqüentemente, nas variações de produtividade obtidas.

As análises foram realizadas pelo laboratório do Departamento de Solos e Nutrição de Plantas da ESALQ/USP e os atributos foram determinados segundo metodologia apresentada por Camargo et al. (1986) e Raij et al. (2001).

Os atributos químicos analisados foram:

- $\mathrm{pH}$ em $\mathrm{Ca} \mathrm{Cl}_{2}$ : método do potenciômetro $\left(\mathrm{CaCl}_{2}\right.$ 0,01 mol. $\left.\mathrm{I}^{-1}\right)$;

- $\mathrm{H}+\mathrm{Al}$ (acidez potencial): método $\mathrm{pH}$ SMP;

- Al (alumínio trocável): método titulometria $\left(1\right.$ mol..$\left.^{-1}\right)$;

- MO (matéria orgânica): método colorimétrico (IAC);

- P (fósforo), $\mathrm{K}$ (potássio), Ca (cálcio), Mg (magnésio): método resina trocadora de íons;

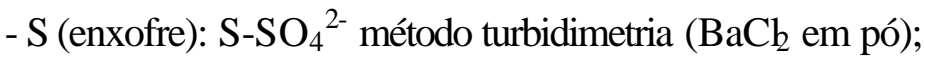

- Cu (cobre), Fe (ferro), Mn (manganês), Zn (zinco): método DTPA (absorção atômica);

- $\mathrm{B}$ (boro): $\mathrm{BaCl} .2 \mathrm{H}_{2} \mathrm{O}$ método microondas.

Os atributos físicos analisados foram:

- porcentagem de areia muito grossa (ArMG), areia grossa (AreG), areia média $(\mathrm{ArM})$, areia fina $(\mathrm{ArF})$, areia muito fina (ArMF), areia total (AreT), silte (Sil) e argila total (ArgT), argila em água (ArgA) e classe de textura: método do densímetro.

Os valores da relação silte/argila (SilAr) foram obtidos com a divisão do valor de silte (\%) pelo de argila total (\%); a SB (soma de bases trocáveis) foi obtida com a soma dos valores de $\mathrm{K}$, $\mathrm{Ca}$ e $\mathrm{Mg}$; $\mathrm{T}(\mathrm{CTC}$ a $\mathrm{pH}$ 7,0) com a soma dos valores de $\mathrm{H}+\mathrm{Al}$ e $\mathrm{SB}$; CTC efetiva com a soma dos valores de $\mathrm{K}, \mathrm{Mg}, \mathrm{Ca}$ e $\mathrm{Al}$; V\% (porcentagem de saturação 
por bases) com a equação SB.100/T; m\% (porcentagem de saturação por alumínio) com a equação Al/(SB+Al).100; e floculação (Flo) com a equação 100 (ArgT-ArgA)/ArgT (Empresa Brasileira de Pesquisa Agropecuária, 1979 e 1997).

Com relação ainda aos atributos do solo, também foram coletadas, com emprego do trado, amostras simples, na profundidade de $0-20 \mathrm{~cm}$, que cuidadosamente foram armazenadas em latas, tampadas e vedadas, para posterior determinação em laboratório da porcentagem de umidade (Umi) atual no solo, por meio do método da estufa a 105$110^{\circ} \mathrm{C}$, de acordo com o manual de métodos de análise de solo da EMBRAPA (1979 e 1997). Com o auxílio da balança de precisão foi efetuada a pré-pesagem da amostra úmida; logo após foi realizada a abertura das latas e secagem das amostras em estufa a $105-110^{\circ} \mathrm{C}$, deixando nestas condições por 24 horas. Após este período elas foram retiradas da estufa para esfriamento e pesadas, agora secas. A porcentagem de umidade no solo foi obtida por meio da multiplicação por 100 da diferença absoluta entre o peso da amostra úmida e o peso da amostra seca, dividida pelo peso da amostra seca. $\mathrm{O}$ valor obtido foi expresso em $\mathrm{g} / 100 \mathrm{~g}$ de amostra seca a $105^{\circ} \mathrm{C}$.

$$
\% \text { umidade }=100 .\left(\frac{\text { peso úmido }- \text { peso seco })}{\text { peso seco }}\right.
$$

No que se refere aos atributos do potencial produtivo, em cada um dos pontos amostrais da grade foi instalada uma parcela circular de 12,6m de raio. $\mathrm{Na}$ área abrangida por esta parcela foram medidos os DAPs, com a suta, e a altura total, com o dendrômetro, das cinco árvores dominantes (com maior DAP). A determinação do raio da parcela foi baseada no cálculo da área da parcela circular, $\mathrm{A}=\pi \cdot \mathrm{r}^{2}$, definida como aproximadamente $500 \mathrm{~m}^{2}$ para a situação de 5 árvores de maior DAP.

A capacidade produtiva para cada um dos pontos amostrais foi expressa por meio do índice de sítio (IS), obtido pela média aritmética da altura total das cinco árvores medidas de cada parcela, tomando a idade de 7 anos como idade-índice. Para o cálculo do IS foi utilizada a equação desenvolvida pela empresa para os povoamentos instalados na região onde os dados foram coletados: 
$I S=M H D O M *((1-\operatorname{EXP}(-0.291133016 * 7)) /(1-\operatorname{EXP}(-0.291133016 * I D)) * * 1.224886563$

sendo:

MHDOM a média aritmética das alturas das 5 árvores de maior DAP;

ID a idade índice.

\subsubsection{Matriz de correlação e regressão}

Com todos os valores dos atributos estudados determinados para cada ponto amostral, no programa SAS 6.12 e no Statistica, foram analisados os coeficientes de correlação (r) por meio da análise da matriz de correlação, análise do coeficiente de determinação $\left(\mathrm{r}^{2}\right)$, do coeficiente de determinação ajustado $\left(\mathrm{R}^{2}\right)$ e do resultado do teste $\mathrm{F}$ (Fisher) por meio da regressão linear simples e regressão linear múltipla, para identificar a existência ou não de correlação, associação e relação causa-efeito entre a variável dependente (IS) e as diversas variáveis independentes, assim como para encontrar um modelo matemático que pudesse ser usado para descrever esta relação, sendo este modelo simples e com poucas variáveis independentes, e estas correlacionadas com a variável dependente e pouco correlacionadas entre si.

Antes da validação dos resultados da análise de regressão, foram verificadas as suposições exigidas pela mesma: homogeneidade de variância; distribuição normal dos resíduos; ausência de multicolineariedade; inexistência de observações influentes.

Quando o valor obtido para $\mathrm{F}(\operatorname{Pr}>\mathrm{F})$ foi maior que 0,05 , com a análise de variância no ambiente SAS LAB, para o teste de suposições, com base em todos os dados obtidos no experimento por meio do procedimento REGRESSÃO (proc reg) permitiu aceitar, a 5\% de significância, a hipótese nula (H0), há fortes evidências estatísticas de que há homogeneidade (homoscedasticidade) das variâncias, e rejeitar a hipótese alternativa (HA), há fortes evidências estatísticas de que há heterogeneidade (heteroscedasticidade) das variâncias. A homogeneidade das variâncias tem uma forte ligação com a normalidade dos dados. 
Com o resultado obtido por meio do teste de normalidade do resíduo, procedimento UNIVARIATE, $(\operatorname{Pr}<W)$, se maior que 0,05 , verifica-se que o teste de Shapiro-Wilk foi significativo a 5\%, indicando a aceitação da hipótese H0, ou seja, os dados do resíduo apresentam distribuição normal e rejeição de (HA), há fortes evidências estatísticas de que os dados do resíduo não apresentam distribuição normal.

Observando os coeficientes de assimetria e curtose, foi verificado se a distribuição dos dados apresentou coeficiente de assimetria e de curtose elevados, o que foi afirmado sempre que estes estiveram fora da faixa entre $-2 \mathrm{e}+2$.

Para verificar se estes coeficientes desviam significativamente de zero e, portanto da normalidade, foi utilizado o critério apresentado por Beiguelman (1994), em que quando o resultado igual ou maior que 1,96 indica que os coeficientes são estatisticamente maiores do que zero e, portanto, apresentam assimetria positiva e distribuição leptocúrtica. Por outro lado, valores iguais ou menores que - 1,96, indicam assimetria negativa e distribuição platicúrtica.

Quando duas variáveis independentes apresentaram um coeficiente de correlação (r) maior que 0,80 , optou-se pela eliminação de uma delas no modelo de regressão linear múltipla, eliminando a presença da multicolinearidade, indicada no SAS LAB. Este procedimento também foi aplicado por Cardenas (1987).

A presença de observações influentes também foi analisada no SAS, por meio do valor do resíduo estudentizado e "dffits" (procedimento R INFLUENCE) para cada observação, que quando fora da faixa entre -2 e +2 , foram consideradas influentes, sendo analisadas separadamente. Valores fora da faixa entre -3 e +3 foram considerados excessivamente influentes, demonstrando que a análise de regressão depende muito destas observações, sendo assim são muito influentes na determinação dos parâmetros da regressão. Optou-se por eliminar estas observações do conjunto de dados.

Quando algumas destas suposições foram violadas aplicou-se, nesta sequiência, as seguintes transformações matemáticas aos dados no ambiente SAS LAB: logarítmica, raiz quadrada e exponente ótimo. Quando a mudança esperada não ocorreu, foram realizadas tentativas com a retirada das observações influentes, sempre mantendo o modelo linear. 
Para validar as regressões foram analisados \& resultados do teste $\mathrm{F}$ e do $\mathrm{r}^{2}$, para regressão linear simples, e além destes, do $\mathrm{R}^{2}$ para regressão linear múltipla.

$\mathrm{Na}$ regressão múltipla também foi analisado o resultado da soma de quadrados total (SQT), que expressa o total de variação dos dados; da soma de quadrados do modelo (SQM), que expressa o quanto desta variação é explicada pelo modelo ajustado; e da soma de quadrados do resíduo (SQR), que expressa o quanto desta variação é explicada pelo resíduo. Por meio da comparação entre o valor do quadrado médio do modelo (QMM) e do quadrado médio do resíduo (QMR) pode-se comprovar se as diferenças no resultado dos modelos testados foi consequiência do acaso (soma dos efeitos de diversos fatores externos) ou das diferenças entre os valores das variáveis independentes inclusas no modelo. Com o valor de $\mathrm{R}^{2}$ foi possível determinar, em porcentagem, o quanto o modelo explica do total de variação dos dados e o quanto é consequência do resíduo. Também foi analisado o valor do coeficiente de variação (CV) para determinar a intensidade de variação dos dados entorno da média, considerando que para dados provindos de experimento de campo é aceito um valor de CV até 30,0.

O resultado obtido com a análise de regressão, no programa SAS, permitiu confirmar ou não a existência de relação causa-efeito entre a variável dependente e a(s) independente(s), com base em todos os dados obtidos no experimento, por meio do procedimento REG. No caso de $\mathrm{F}(\mathrm{Pr}>\mathrm{F})$ menor que 0,05 , foi aceito, a $5 \%$ de significância, HA - existe relação de dependência entre as variáveis. Este valor também permitiu rejeitar H0 - não há relação de dependência entre as variáveis, concluíndo que há fortes evidências estatísticas de que existe relação causa-efeito entre a variável dependente e a(s) independente(s).

É a partir do teste F (Fisher) que se avalia se há relação de dependência entre duas

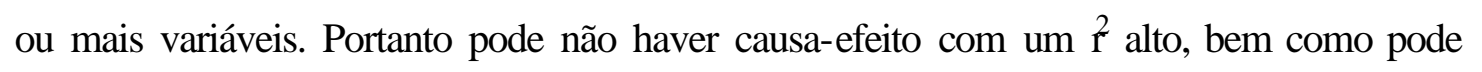
havê-la com um valor baixo de $\mathrm{r}^{2}$.

Para o processo de redução do número de variáveis explicativas a serem consideradas no ajuste do modelo de regressão múltipla, foi utilizado o método passo-apasso ("stepwise forward"). Posteriormente foi aplicado o método que usa todas as 
regressões possíveis ("adjrsquare") no conjunto de dados inicial (com todas as variáveis) e no sub-conjunto de variáveis explicativas obtido com o método passo-a-passo.

\subsubsection{Análise geoestatística}

Inicialmente foi realizado o resumo estatístico dos valores de cada conjunto de dados, seguindo o proposto por Libardi a al. (1996), Salviano (1996) e Farias (1999), com a determinação de medidas de posição (média, mediana e moda) e dispersão (valores mínimo e máximo, limites inferior e superior, variância, desvio-padrão, coeficiente de variação, amplitudes total e interquartílica, quartis superior e inferior) e forma (gráfico de probabilidade normal, coeficiente de simetria e curtose); a análise exploratória dos dados (gráfico de caixa), dispositivo de ramos e folhas e gráficos por linhas e por colunas); e o ajuste dos dados à distribuição normal, a 5\% de significância, com base nos testes de Shapiro-Wilk (W) e Kolmogorov-Smirnov (KS); todas estas etapas utilizando os pacotes estatísticos Excel, SAS e Statistica. A partir destas análises pôde-se visualizar a distribuição e o comportamento geral dos dados e detectar dados influentes, observações com valores extremos que destoam do conjunto de dados e alteram os valores de algumas medidas, assim como verificar a normalidade dos dados, necessária para a aplicação dos testes estatísticos convencionais.

Para o cálculo do limite inferior (LI) e do limite superior (LS) foi adotado o critério de Hoaglin et al. (1983), que considera como prováveis dados discrepantes valores menores que a diferença entre o quartil inferior (Qi) e 1,5 vez a amplitude interquartílica (Ai), ou seja, aqueles abaixo do LI, estimado por LI=Qi 1,5.Ai, e dados com valores maiores que a soma do quartil superior (Qs) com 1,5 vez a amplitude interquartílica, ou seja, acima do LS, estimado por LS=Qs+1,5.Ai.

Nos casos em que os atributos estudados apresentaram observações com valores extremos, estas foram descartadas e, nessa situação, foram aplicados novamente os procedimentos citados sem as observações com valores extremos. Os resultados obtidos com este conjunto de dados foram comparados com os resultados anteriores, verificando se a retirada das observações com valores extremos implicou em uma modificação 
significativa e positiva dos valores das medidas estatísticas. Se a modificação não foi significativa, elas foram readmitidas; se foi significativa, foram excluídas do conjunto. A decisão final sobre excluir ou não qualquer observação foi tomada após confrontar os candidatos a dados influentes com seus vizinhos mais próximos, nos gráficos de distribuição espacial ("postplot"), gerados no programa Surfer, procedimento indicado por Libardi et al. (1996).

A geoestatística foi utilizada para verificar a existência e, neste caso, quantificar o grau de dependência espacial dos valores das variáveis estudadas, a partir do ajuste de funções teóricas aos modelos de semivariogramas (esférico, gaussiano, exponencial e linear com patamar), gerados no GS+ e Geoeas, para cada variável estudada.

Em seguida os semivariogramas foram escalonados pela variância, de acordo com Vieira et al. (1998), com isso o efeito pepita tornourse automaticamente uma fração do patamar, facilitando as interpretações e comparações entre semivariogramas de diferentes atributos, visto que assim pode se verificar se contam com o mesmo padrão de variabilidade espacial, uma vez que assumem valores em uma escala padronizada.

Para a análise do grau de dependência espacial das variáveis foi utilizada a classificação de Cambardella et al. (1994), onde são considerados de forte dependência espacial os semivariogramas que têm efeito pepita $\leq 25 \%$ do patamar, moderada quando entre $25 \%$ e $75 \%$ e de fraca quando $>75 \%$. De acordo com Vieira (1997 e 1998), quanto menor a proporção do efeito pepita para o patamar, maior será a semelhança entre os valores vizinhos e a continuidade do fenômeno e menor a variância da estimativa e, portanto, maior a confiança que se pode ter nas estimativas.

Com o ajuste de semivariogramas foi assumida a suposição de estacionaridade fraca, hipótese intrínseca, e definidos os parâmetros (alcance, efeito pepita, variância estrutural e patamar) necessários para a estimativa de valores para locais não amostrados, por meio do uso do método de interpolação por krigagem ordinária.

Posteriormente, foi avaliado o número ideal de vizinhos para a krigagem eo erro da estimativa por meio da validação cruzada, utilizando como parâmetros de decisão o gráfico do erro de estimativa, no Geoeas, procurando-se atingir o equilíbrio entre valores sub e super estimados pela krigagem, evidenciado pelos dois lados da diagonal da reta 
1:1, apresentando um número aproximadamente igual de observações; mapa dos erros; histograma; coeficiente de correlação entre valor observado e estimado próximo a 1. Seguindo metodologia proposta por Vieira et al. (1983), Vieira (1995) e Vieira \& Lombardi Neto (1995) empregada nos trabalhos de Ribeiro Junior (1995), Garcia Y Garcia (1997), Gonçalves (1997), Fietz (1998) e Ortiz (2002), utilizou-se, também, o erro de estimativa, usando o módulo "Xvalid" do Geoeas, com média reduzida $\left(\mathrm{m}_{\mathrm{r}}\right)$ igual a zero e variância reduzida $\left(\mathrm{s}^{2}\right.$ red $)$ unitária, esta última obtida pelo valor do desvio padrão das diferenças padronizadas elevado ao quadrado.

\subsubsection{Mapeamento da variabilidade espacial e regressão espacial}

Com o uso da krigagem foram gerados mapas de isolinhas (contorno) e superfícies contínuas (MDT e MDE) para cada atributo do solo, relevo e capacidade produtiva, no GS+ (utilizando os módulos "Semivariance Analysis", "Krig-Interpolate" e "Map"). Posteriormente, os parâmetros geoestatísticos utilizados na construção destes, foram empregados para a geração dos mesmos mapas no Surfer (utilizando os módulos "Scattered Data Interpolation" e "Surface"). A falta de interface do GS+, versão DEMO, com o Idrisi, faz com que seja impossível a exportação dos mapas criados no GS+, para o Idrisi; contrastando com a excelente interface do Surfer com o Idrisi, que possibilita a exportação dos mapas criados no Surfer, com seus respectivos valores de x,y e z, para o Idrisi, tornando possível a realização da regressão linear múltipla espacial.

O MDT (modelo digital do terreno) e os MDEs (modelos digitais de elevação) foram exportados do Surfer para o Idrisi com o uso do módulo "Gride Node Editor", onde o arquivo *.grd foi transformado para GS ASCII (*.grd). Para a exportação, os arquivos, que inicialmente contavam com 50 colunas e 38 linhas, foram modificados para 385 colunas e 432 linhas por meio do módulo "Spline Smooth". No Idrisi foi utilizado o módulo "Import" opção SRFIDRIS (Surfer). O maior número de linhas e colunas do arquivo, aumenta o número de "pixels" da imagem, diminuíndo o tamanho destes, o que suaviza o contorno da imagem, melhorando a representação da distribuição dos atributos estudados no interior do talhão, o que por sua vez fornece maior precisão nas análises 
dentro do SIG, assim como melhor apresentação do mapa de distribuição de cada atributo estudado.

Do MDT foram derivados, no Idrisi, os modelos de face de exposição (azimute) e declividade (em porcentagem e em graus) utilizando o módulo "Surface" ("Aspect" e "Slope" - "degrees" e "percent").

O mapa de exposição de vertentes teve seus valores agrupados em classes definidas pelo octante, de acordo com De Biasi et al. (1977) e Moretti et al. (1989), conforme Tabela 2.

Tabela 2. Classes de exposição de vertentes

\begin{tabular}{cccc}
\hline CLASSE & FACE & DE & ATÉ \\
\hline 1 & N (norte) & $337^{\circ} 30^{\prime}$ & $22^{\circ} 30^{\prime}$ \\
2 & NE (nordeste) & $22^{\circ} 30^{\prime}$ & $67^{\circ} 30^{\prime}$ \\
3 & E (leste) & $67^{\circ} 30^{\prime}$ & $112^{\circ} 30^{\prime}$ \\
4 & SE (sudeste) & $112^{\circ} 30^{\prime}$ & $157^{\circ} 30^{\prime}$ \\
5 & S (sul) & $157^{\circ} 30^{\prime}$ & $202^{\circ} 30^{\prime}$ \\
6 & SO (sudoeste) & $202^{\circ} 30^{\prime}$ & $247^{\circ} 30^{\prime}$ \\
7 & O (oeste) & $247^{\circ} 30^{\prime}$ & $292^{\circ} 30^{\prime}$ \\
8 & NO (noroeste) & $292^{\circ} 30^{\prime}$ & $337^{\circ} 30^{\prime}$ \\
\hline
\end{tabular}

O mapa de declividade teve seus valores (em porcentagem) agrupados em classes definidas de acordo com com o proposto por Ramalho Filho et al. (1978). A Tabela 3 apresenta os valores de declividade agrupados em classes, assim como a descrição destas. 
Tabela 3. Classes clinográficas (em porcentagem)

\begin{tabular}{|c|c|c|}
\hline CLASSE & INTERVALO & DESCRIÇÃO \\
\hline 1 & $<3 \%$ & $\begin{array}{l}\text { Relevo plano; fácil controle do processo erosivo; após 10- } \\
20 \text { anos de cultivo o horizonte A continua intacto. }\end{array}$ \\
\hline 2 & $3 \%-8 \%$ & $\begin{array}{l}\text { Relevo suave ondulado; fácil controle do processo erosivo } \\
\text { por meio do plantio de árvores; após } 10-20 \text { anos de cultivo } \\
\text { cerca de } 25 \% \text { do horizonte A será removido da maior parte } \\
\text { da área. }\end{array}$ \\
\hline 3 & $8 \%-20 \%$ & $\begin{array}{l}\text { Relevo ondulado; o plantio de árvores sem a completa } \\
\text { remoção da vegetação se constitui em um eficiente } \\
\text { controle erosivo, impedindo a formação de pequenas } \\
\text { voçorocas; após } 10-20 \text { anos de cultivo entre } 25 \% \text { de } 75 \% \\
\text { o horizonte A será removido da maior parte da área. }\end{array}$ \\
\hline 4 & $20 \%-45 \%$ & $\begin{array}{l}\text { Relevo forte ondulado; ocorrência de voçorocas pequenas } \\
\text { e médias, o controle do processo erosivo é difícil, } \\
\text { dispendioso e inviável; após } 10-20 \text { anos de cultivo, mais } \\
\text { de } 75 \% \text { do horizonte A será removido da maior parte da } \\
\text { área. }\end{array}$ \\
\hline 5 & $>45 \%$ & $\begin{array}{l}\text { Relevo montanhoso e escarpado; ocorrência de voçorocas } \\
\text { médias e profundas, que praticamente inutilizam a área; o } \\
\text { horizonte A será completamente removido em poucos } \\
\text { anos de cultivo. }\end{array}$ \\
\hline
\end{tabular}

Fonte: Ramalho-Filho (1978)

Foi gerado um segundo mapa de declividade, com seus valores (em graus) agrupados em classes definidas de acordo com as condições da área de estudo e procurando seguir orientações já estabelecidas em trabalhos anteriores, como o do IPT (1981a), Mendes (1982), De Biasi (1970 e 1992), Ross (1994) e Santos (1996). A Tabela 4 apresenta os valores de declividade agrupados em classes, assim como a descrição destas. 
Tabela 4. Classes clinográficas (em graus)

\begin{tabular}{crl}
\hline CLASSE & INTERVALO & DESCRIÇÃO \\
\hline 1 & $0^{\circ}-12^{\circ}$ & Limite máximo do emprego de mecanização agrícola. \\
2 & $12^{\circ}-15^{\circ}$ & Limite considerado para a classe de baixa declividade. \\
3 & $15^{\circ}-20^{\circ}$ & Início da classe considerada como de média declividade \\
4 & $20^{\circ}-25^{\circ}$ & Engloba o limite máximo de corte raso. \\
5 & $25^{\circ}-35^{\circ}$ & Dentro dessas não é permitida a derrubada de florestas. \\
6 & $35^{\circ}-50^{\circ}$ & \\
\hline
\end{tabular}

Nos três mapas derivados do MDT, os valores foram agrupados em classes por meio do módulo "Reclass" - "Image" no Idrisi. Utilizando a função AREA foi calculada e identificada a área total de cada classe de declividade.

Para apresentação, estes mapas foram exportados para o Surfer. Para tanto, no Idrisi estes mapas foram salvos com a extensão *.bmp. No Surfer foi aberto o mapa de contornos representando cotas; foi utilizado o módulo "Load Base Map", para trazer, por exemplo, a imagem declividade.bmp junto, em tela, a cotas.grd. $\mathrm{O}$ uso do comando "Base Map" possibilitou converter as coordenadas desta imagem (Xmáx e Xmín; Ymáx e Ymín), que foram igualadas as de cotas.grd (Xmáx $=427930 \mathrm{~m}$ e Xmín $=427546 \mathrm{~m}$; Ymáx = 7398780m e Ymín = 7398350m). Por fim, foi selecionado o módulo "Overlay Maps" que possibilitou apresentar as imagens face de exposição e declividade juntamente com o mapa de curvas de nível da área, na forma de mapa de contorno. Não foi possível apresentá-los em 3D, visto que o Surfer não consegue combinar uma imagem 3D com uma raster.

Utilizando o módulo "Extract" foi possível extrair os valores das variáveis face de exposição e declividade (porcentagem e graus) em cada um dos 41 pontos amostrais da grade e, assim, inserí-los no conjunto de dados. Para isto foram utilizadas as imagens derivadas do MDT, face de exposição e declividade, e um arquivo *.dat com as coordenadas planas (x,y) e $\mathrm{z}$ (n..$^{-}$da amostra), que foi importado usando a função XYZIDRIS. A extração dos valores possibilitou a entrada das variáveis face de exposição, declividade em graus e em porcentagem na análise estatística convencional 
(correlação, regressão linear simples e múltipla, no SAS e no Statistica) usando 41 valores, visto que estes dados não foram coletados diretamente no campo e só ficaram disponíveis após esta operação no SIG.

De posse dos modelos digitais de todas as variáveis, foram determinadas estatisticamente, no Idrisi, por meio de análise de correlação e regressão espacial entre mapas (regressão pixel-a-pixel), que tem a vantagem de levar em conta a posição espacial dos dados, as correlações e relações entre potencial produtivo (índice de sítio) e atributos do solo e do relevo. Para tanto foram utilizados o módulo "Regress" e uma máscara representando a área de estudo, permitindo que a análise de regressão fosse restrita aos dados presentes nos 8,4ha da área, impedindo extrapolações.

A máscara foi confeccionada utilizando-se o arquivo em *.dwg do AutoCAD pertencente a Cia. Suzano de Papel e Celulose com todas as informações referentes à cartografia do talhão 06. No AutoCAD, o contorno (fechado) da área do experimento foi colocado em um "layer" (camada ou plano) separado. Utilizando a função Limite foi criado o polígono representando a área. Com as funções Alterar $\Rightarrow$ Propriedades $\Rightarrow$ Elevação foi dado valor de $\mathrm{z}$ igual a 1 para o polígono representando os 8,4ha do interior da área de estudo. Este "layer" foi então exportado como *.dxf (ASCII) e importado no Idrisi usando a função DXFIDRIS como polígono com atributo valor de z. No módulo "Reformat" foi utilizada a função "Raster/Vector Conversion" (POLYRAS) para rasterização, ou seja, conversão do arquivo "máscara", da forma vetorial para raster. O uso da função "Initial" possibilitou a geração da imagem de fundo para "máscara" com os parâmetros da imagem cotas.

Para análise dos resultados refentes à correlação linear espacial foi utilizado o valor de r; já para a regressão linear simples foi usado o valor de $\mathrm{r}^{2}$. Por meio do módulo "Multireg " e da "máscara" foi efetuada a regressão linear múltipla espacial, sendo que os resultados foram analisados pelo mesmo critério empregado por Jakob et al. (1999), ou seja, verificando o valor da estatística $F$ (Fisher) e levando-se em conta o valor do $R^{2}$. Posteriormente, para análise visual comparativa, foi apresentado o mapa de isolinhas com os valores de IS preditos a partir dos modelos de regressão linear múltipla espacial ajustados e o mapa de isolinhas com os valores de IS estimados pela krigagem. 
Nesta etapa surgiu uma dificuldade íntrinseca ao SIG Idrisi; a identificação das variáveis independentes que melhor explicam as variações do IS, ou seja, a inclusão das variáveis que contribuem de modo significativo para melhorar a qualidade do modelo ajustado. O Idrisi não conta com procedimentos para auxiliar o processo de redução do número de variáveis explicativas a serem consideradas no ajuste do modelo de regressão. Além disto, nele é possível a entrada de no máximo 10 variáveis independentes no modelo de regressão. Os mapas interpolados de todas as variáveis poderiam ser convertidos no Idrisi para o formato $\mathrm{x}, \mathrm{y}, \mathrm{z}$ e exportados como tabelas a serem abertas no Excel e, posteriormente, organizados em um arquivo, possibilitando a entrada destes dados num programa estatístico convencional como o SAS, assim como, a realização da análise de regressão múltipla, utilizando o procedimento "stepwise forward", como feito anteriormente com as 41 observações. Os melhores modelos com até 10 variáveis seríam selecionados e as variáveis incluídas nestes, seriam testadas no módulo "Multireg" do Idrisi. O problema é que no SAS seríam 81.919,0 observações para cada variável e não 41, uma vez que no mapa interpolado é atribuído valor de $\mathrm{Z}$ para locais não amostrados, o que torna a operação inviável, em função do tempo e do trabalho a ser dispendido para conversão, exportação, montagem e análise deste arquivo com 81.919,0 observações para cada uma das 33 variáveis. Outro ponto negativo é que a regressão múltipla no SAS seria realizada com a perda da posição espacial dos dados, pois não considera a mesma, modificando a posição dos limites dos atributos estudados. Estes fatores fizeram com que fosse rejeitada a hipótese de efetuar todo este processo.

Optourse, então, pela entrada no modelo de regressão espacial das mesmas variáveis que melhor explicam as variações do IS, utilizando a regressão linear múltipla com 41 observações. Também foi testada a exclusão de algumas e inclusão de outras que poderíam contribuir de modo significativo para melhorar a qualidade do modelo ajustado. Foram íncluídas variáveis com valores altos de $\mathrm{r}$ e $\mathrm{r}^{2}$, pela regressão linear simples espacial com IS, e excluídas aquelas com valores baixos. Portanto, o processo de redução do número de variáveis explicativas foi manual e não automático. Esta adptação foi efetuada devido às semelhanças verificadas dos valores obtidos para $r$ e $r^{2}$, na regressão linear simples espacial entre as variáveis independentes e IS e na regressão 
linear convencional entre as variáveis independentes e IS. A vantagem deste processo, foi a manutenção das características da regressão pixel-a-pixel, mais adequada para o processamento de dados para agricultura e silvicultura de precisão do que programas de estatística convencionais, pois mantem e leva em conta a posição espacial dos pontos nas análises.

A "máscara" da área de estudo também possibilitou apresentar somente as informações de seu interior nos mapas de declividade e face de exposição. Para tanto a imagem face de exposição bruta foi multiplicada pela imagem "máscara", por meio da operação boolena "Overlay". Como o interior da "máscara" tem valor de z igual a 1 e o exterior 0 , ao multiplicarmos esta imagem pela imagem face de exposição bruta, todo ponto fora da área de estudo passa a ter valor de $\mathrm{z}$ igual a 0 e o interior continua com o valor da face de exposição.

O módulo "Reclass" - "Image" possibilitou reclassificar o mapa de face de exposição, ou seja, foi dado valor de 1 a 8 de acordo com a face ocupada pelo ponto (N, NE, NO, S, SE, SO, L, O). Posteriormente utilizou-se o módulo "Regress" para cruzar as informações entre o mapa de IS e o de face de exposição reclassificado e, assim, identificar quais as faces mais e menos produtivas. Adotou-se este critério devido aos valores dos pontos amostrais localizados na face de exposição $\mathrm{N}$, que podem ser representados pelos intervalos entre $0^{\circ}-22^{\circ} 30^{\prime}$ e $337^{\circ} 30^{\prime}-360^{\circ}$. Adotando estes valores brutos, em graus, não seria lógico aplicar uma análise de regressão aos dados da face de exposição, visto que, por exemplo não seria possível estabelecer que a face $\mathrm{N}$ é a mais ou a menos produtiva de todas. Se ela fosse menos produtiva, os pontos amostrais localizados no intervalo entre $0^{\circ}-22^{\circ} 30^{\prime}$ "puxaríam" o ínicio da reta de regressão para baixo e os pontos amostrais localizados entre $337^{\circ} 30^{\prime}-360^{\circ}$ "puxaríam" o final de reta para baixo, o inverso ocorrendo caso fosse mais produtiva. Este cenário tornaria impossível verificar qualquer relação entre IS e face de exposição, assim como identificar as faces mais e as menos produtivas. 


\section{RESULTADOS E DISCUSSÃO}

\subsection{Análises dos dados coletados}

Nas tabelas A, B, C (Anexos) são apresentados os resultados obtidos para as amostras de solo, das análises químicas para os macronutrientes; das análises físicas; das análises químicas para os micronutrientes em conjunto com a umidade do solo, cotas altimétricas, altura total (H), DAP e índice de sítio (IS).

\subsection{Estatística clássica}

\subsubsection{Matriz de correlação}

Na Tabela 5 é apresentada a matriz de correlação com os dados originais, sem as observações influentes, onde as correlações com $r$ igual ou maior que 0,40 são consideradas significativas ao nível de $1 \%$ de probabilidade $(\mathrm{P} \leq 0,01)$ e com $\mathrm{r}$ igual ou maior que 0,30 são consideradas significativas ao nível de $5 \%$ de probabilidade ( $\mathrm{P} \leq 0,05)$. 
Tabela 5. Matriz de correlação com o conjunto de dados originais, sem as observações influentes

\begin{tabular}{|c|c|c|c|c|c|c|c|c|c|c|c|c|c|c|c|c|c|c|}
\hline Variáveis & Cot & IS & pH & MO & $\mathbf{P}$ & $\mathbf{K}$ & $\mathbf{C a}$ & Mg & Al & $\mathbf{H}+\mathrm{Al}$ & $\mathbf{S}$ & SB & $\mathbf{T}$ & $\bar{V}$ & $\mathbf{m}$ & CTC & $\mathrm{Cu}$ & $\mathbf{Z n}$ \\
\hline Cot & 1,00 & $-0,62$ & $-0,46$ & 0,39 & 0,24 & $-0,48$ & 0,06 & $-0,25$ & 0,43 & 0,56 & 0,48 & $-0,29$ & 0,55 & $-0,49$ & 0,44 & 0,36 & $-0,40$ & $-0,47$ \\
\hline IS & & 1,00 & 0,11 & $-0,31$ & 0,07 & 0,21 & $-0,13$ & 0,17 & $-0,36$ & $-0,30$ & $-0,30$ & 0,10 & $-0,29$ & 0,20 & $-0,20$ & $-0,14$ & 0,28 & 0,20 \\
\hline $\mathrm{pH}$ & & & 1,00 & $-0,60$ & $-0,40$ & 0,45 & 0,00 & 0,21 & $-0,71$ & $-0,81$ & $-0,09$ & 0,32 & $-0,80$ & 0,64 & $-0,63$ & $-0,51$ & 0,45 & 0,29 \\
\hline MO & & & & 1,00 & 0,21 & $-0,30$ & 0,30 & $-0,09$ & 0,77 & 0,85 & 0,29 & $-0,03$ & 0,85 & $-0,36$ & 0,39 & 0,76 & $-0,49$ & $-0,23$ \\
\hline $\mathrm{P}$ & & & & & 1,00 & $-0,33$ & 0,24 & 0,43 & 0,36 & 0,38 & $-0,24$ & 0,23 & 0,38 & 0,02 & $-0,02$ & 0,37 & 0,02 & 0,23 \\
\hline K & & & & & & 1,00 & 0,07 & 0,17 & $-0,35$ & $-0,44$ & $-0,19$ & 0,54 & $-0,43$ & 0,60 & $-0,61$ & $-0,24$ & 0,27 & 0,31 \\
\hline $\mathrm{Ca}$ & & & & & & & 1,00 & 0,47 & 0,21 & 0,08 & $-0,07$ & 0,73 & 0,10 & 0,52 & $-0,45$ & 0,38 & 0,03 & 0,17 \\
\hline $\mathrm{Mg}$ & & & & & & & & 1,00 & $-0,14$ & $-0,13$ & $-0,29$ & 0,86 & $-0,08$ & 0,74 & $-0,79$ & 0,27 & 0,27 & 0,53 \\
\hline $\mathrm{A} 1$ & & & & & & & & & 1,00 & 0,89 & 0,08 & $-0,11$ & 0,90 & $-0,46$ & 0,57 & 0,97 & $-0,44$ & $-0,17$ \\
\hline $\mathrm{H}+\mathrm{Al}$ & & & & & & & & & & 1,00 & 0,20 & $-0,24$ & 0,99 & $-0,60$ & 0,61 & 0,70 & $-0,53$ & $-0,31$ \\
\hline$S$ & & & & & & & & & & & 1,00 & $-0,30$ & 0,20 & $-0,38$ & 0,28 & 0,04 & $-0,08$ & $-0,33$ \\
\hline SB & & & & & & & & & & & & 1,00 & $-0,21$ & 0,86 & $-0,86$ & 0,11 & 0,30 & 0,50 \\
\hline $\mathrm{T}$ & & & & & & & & & & & & & 1,00 & $-0,58$ & 0,59 & 0,76 & $-0,52$ & $-0,27$ \\
\hline V & & & & & & & & & & & & & & 1,00 & $-0,92$ & $-0,27$ & 0,45 & 0,55 \\
\hline $\mathrm{m}$ & & & & & & & & & & & & & & & 1,00 & 0,38 & $-0,46$ & $-0,50$ \\
\hline CTC & & & & & & & & & & & & & & & & 1,00 & $-0,35$ & 0,08 \\
\hline $\mathrm{Cu}$ & & & & & & & & & & & & & & & & & 1,00 & 0,53 \\
\hline $\mathrm{Zn}$ & & & & & & & & & & & & & & & & & & 1,00 \\
\hline
\end{tabular}


Tabela 5. Matriz de correlação com o conjunto de dados originais, sem as observações influentes

\begin{tabular}{|c|c|c|c|c|c|c|c|c|c|c|c|c|c|c|c|c|c|c|}
\hline Variáveis & Cot & IS & pH & MO & $\mathbf{P}$ & $\mathbf{K}$ & $\mathbf{C a}$ & Mg & Al & $\mathrm{H}+\mathrm{Al}$ & $\bar{S}$ & SB & $\mathbf{T}$ & $\mathbf{V}$ & m & CTC & $\mathbf{C u}$ & Zn \\
\hline $\mathrm{Mn}$ & 044 & 0,33 & 0,24 & $-0,29$ & 0,02 & 0,32 & 0,02 & 0,35 & $-0,25$ & $-0,37$ & $-0,41$ & 0,31 & $-0,33$ & 0,39 & $-0,40$ & $-0,02$ & 0,31 & 0,75 \\
\hline $\mathrm{Fe}$ & 0,26 & $-0,13$ & $-0,58$ & 0,54 & 0,08 & $-0,30$ & $-0,06$ & $-0,37$ & 0,51 & 0,61 & $-0,02$ & $-0,36$ & 50,60 & $-0,53$ & 0,55 & 0,28 & $-0,51$ & $-0,24$ \\
\hline B & 0,29 & $-0,26$ & & 0,13 & 0,14 & $-0,18$ & 0,04 & $-0,04$ & 0,17 & 0,33 & $-0,01$ & $-0,09$ & 0,33 & $-0,16$ & 0,10 & 0,16 & $-0,10$ & $-0,11$ \\
\hline ArMG & $-0,63$ & 0,26 & 0,45 & $-0,37$ & $-0,38$ & 0,35 & $-0,11$ & 0,05 & $-0,42$ & $-0,4$ & $-0,22$ & 0,12 & $-0,49$ & 0,29 & $-0,34$ & $-0,37$ & 0,43 & 0,23 \\
\hline AreG & $-0,51$ & 0,16 & 0,13 & $-0,08$ & $-0,13$ & 0,11 & $-0,12$ & 0,00 & $-0,04$ & 17 & $-0,39$ & 0,00 & $-0,17$ & 0,06 & $-0,06$ & $-0,10$ & 0,08 & 0,24 \\
\hline ArM & 0,14 & $-0,10$ & 0,00 & 0,07 & 0,24 & $-0,12$ & 0,24 & $-0,11$ & 0,10 & 0,00 & 0,09 & 0,00 & 0,00 & 0,03 & $0,0 J$ & 0,00 & 0,10 & 0,17 \\
\hline $\mathrm{ArF}$ & $-0,42$ & 0,17 & 0,54 & $-0,32$ & $-0,40$ & 0,38 & $-0,08$ & $-0,13$ & $-0,46$ & $-0,4 \delta$ & $-0,05$ & 0,03 & $-0,47$ & 0,25 & $-0,29$ & $-0,40$ & 0,31 & 0,18 \\
\hline ArMF & $-0,55$ & 0,24 & 0,42 & $-0,42$ & $-0,48$ & 0,40 & $-0,21$ & 0,03 & $-0,47$ & $-0,4$ & $-0,31$ & 0,07 & $-0,41$ & 0,29 & $-0,32$ & $-0,30$ & 0,13 & 0,10 \\
\hline AreT & $-0,71$ & 0,25 & 0,52 & $-0,37$ & $-0,37$ & 0,36 & $-0,08$ & $-0,06$ & $-0,42$ & $-0,53$ & $-0,31$ & 0,07 & $-0,53$ & 0,30 & $-0,32$ & $-0,40$ & 0,38 & 0,34 \\
\hline Sil & 0,20 & $-0,01$ & 017 & 0,08 & 0,20 & $-0,21$ & 0,27 & 0,22 & 0,11 & 0,10 & 0,04 & 0,19 & 0,09 & 0,12 & $-0,05$ & 0,09 & $-0,14$ & $-0,08$ \\
\hline $\operatorname{Arg} T$ & 0,79 & $-0,32$ & & 0,42 & 0,36 & $-0,3$ & $00=$ & $-0,0 J$ & 0,48 & 0,62 & 0,37 & $-0,20$ & 0,63 & $-0,46$ & 0,44 & 0,47 & $-0,41$ & $-0,40$ \\
\hline $\operatorname{Arg} \mathrm{A}$ & $-0,10$ & $-0,1$ &, 0 & 0,17 & $-0,1$ & & $-0,2$ & $-0,09$ & 0,02 & $-0,0$ & $-0,15$ & $-0,2$ & $-0,04$ & $-0,12$ & 0,17 & 0,02 & $-0,04$ & $-0,16$ \\
\hline Flo & 0,41 & $-0,01$ & $-0,22$ & 0,36 & 0,26 & $-0,04$ & 0,17 & 0,05 & 0,18 & 0,32 & 0,30 & 0,09 & 0,32 & $-0,10$ & 0,05 & 0,18 & $-0,15$ & $-0,02$ \\
\hline SilAr & 0,02 & 0,06 & $-0,02$ & $-0,03$ & 0,11 & $-0,10$ & 0,31 & 0,25 & 001 & 007 & $-0,04$ & 0,27 & $-0,08$ & 0,27 & $-0,18$ & $-0,03$ & $-0,01$ & 0,05 \\
\hline Decl & 0,17 & $-0,14$ & 0,01 & $-0,05$ & $-0,05$ & $-0,34$ & $-0,12$ & $-0,20$ & $-0,00$ & $-0,02$ & 0,45 & $-0,31-$ & $-0,05$ & $-0,26$ & 0,17 & $-0,24$ & 0,25 & $-0,11$ \\
\hline Face & $-0,26$ & 0,07 & 0,15 & 0,00 & 0,26 & 0,24 & 0,41 & 0,37 & $-0,10$ & $-0,20$ & $-0,19$ & 0,49 & $-0,18$ & 0,47 & $-0,44$ & $-0,01$ & 0,11 & 0,40 \\
\hline Umi & 0,62 & $-0,37$ & $-0,69$ & 0,38 & 0,27 & $-0,46$ & $-0,16$ & $-0,23$ & 0,59 & 0,66 & 0,03 & $-0,38$ & 0,65 & $-0,60$ & 0,59 & 0,43 & $-0,62$ & $-0,46$ \\
\hline
\end{tabular}


Tabela 5. Matriz de correlação com o conjunto de dados originais, sem as observações influentes

\begin{tabular}{|c|c|c|c|c|c|c|c|c|c|c|c|c|c|c|c|c|}
\hline Variáveis & Mn & $\mathbf{F e}$ & B & ArMG & AreG & ArM & $\overline{\text { ArF }}$ & ArMF & AreT & Sil & ArgT & ArgA & Flo & SilAr & Decl Face & Umi \\
\hline $\mathrm{Mn}$ & 1,00 & $-0,10$ & $-0,18$ & 0,21 & 0,37 & $-0,11$ & 0,27 & 0,35 & 0,38 & $-0,15$ & $-0,40$ & $-0,18$ & 0,01 & $-0,04$ & $-0,260,15$ & $\overline{-0,30}$ \\
\hline $\mathrm{Fe}$ & & 1,00 & 0,10 & $-0,36$ & 0,18 & 0,08 & $-0,15$ & $-0,07$ & $-0,11$ & $-0,05$ & 0,18 & $-0,05$ & 0,16 & $-0,12$ & $-0,04-0,15$ & 0,49 \\
\hline B & & & 1,00 & 0,05 & $-0,27$ & $-0,03$ & $-0,13$ & 0,07 & $-0,15$ & 0,14 & 0,12 & 0,07 & $-0,02$ & 0,11 & $-0,01-0,11$ & 0,19 \\
\hline ArMG & & & & 1,00 & 0,41 & $-0,32$ & 0,47 & 0,57 & 0,76 & $-0,49$ & $-0,69$ & 0,23 & $-0,53$ & $-0,35$ & $-0,14-0,10$ & $-0,60$ \\
\hline AreG & & & & & 1,00 & $-0,17$ & 0,04 & 0,29 & 0,63 & $-0,36$ & $-0,60$ & 0,30 & $-0,50$ & $-0,23$ & $-0,150,04$ & $-0,14$ \\
\hline ArM & & & & & & 1,00 & 0,14 & $-0,42$ & 0,10 & $-0,05$ & $-0,10$ & $-0,38$ & 0,31 & 0,01 & $0,34 \quad 0,45$ & $-0,13$ \\
\hline $\mathrm{ArF}$ & & & & & & & 1,00 & 0,54 & 0,73 & $-0,58$ & $-0,60$ & $-0,22$ & $-0,05$ & $-0,44$ & $-0,100,05$ & $-0,65$ \\
\hline ArMF & & & & & & & & 1,00 & 0,60 & $-0,39$ & $-0,54$ & 0,21 & $-0,41$ & $-0,28$ & $-0,37-0,22$ & $-0,40$ \\
\hline AreT & & & & & & & & & 1,00 & $-0,67$ & $-0,90$ & 0,05 & $-0,42$ & $-0,46$ & $-0,110,10$ & $-0,67$ \\
\hline Sil & & & & & & & & & & 1,00 & 0,27 & $-0,12$ & 0,23 & 0,96 & $0,10 \quad 0,20$ & 0,27 \\
\hline ArgT & & & & & & & & & & & 1,00 & 0,00 & 0,41 & 0,03 & $0,09-0,25$ & 0,70 \\
\hline $\operatorname{Arg} \mathrm{A}$ & & & & & & & & & & & & 1,00 & $-0,90$ & $-0,14$ & $-0,03-0,27$ & 0,23 \\
\hline Flo & & & & & & & & & & & & & 1,00 & 0,16 & $0,08 \quad 0,13$ & 0,10 \\
\hline SilAr & & & & & & & & & & & & & & 1,00 & $\begin{array}{ll}0,09 & 0,29\end{array}$ & 0,09 \\
\hline Decl & & & & & & & & & & & & & & & $1,00 \quad 0,03$ & 0,05 \\
\hline Face & & & & & & & & & & & & & & & 1,00 & $-0,32$ \\
\hline Umi & & & & & & & & & & & & & & & & 1,00 \\
\hline
\end{tabular}

** $\mathrm{r} \geq 0,40$ são considerados significativos ao nível de $1 \%$ de probabilidade $(\mathrm{P} \leq 0,01)$.

* $\mathrm{r} \geq 0,30$ são considerados significativos ao nível de $5 \%$ de probabilidade $(\mathrm{P} \leq 0,05)$. 
Os resultados obtidos indicam que a variável que apresenta maior correlação linear com IS é cotas, concordando com Carmean (1975), Spurr \& Barnes (1980), Ferreira \& Couto (1981), Callaway et al. (1987), Morris \& Parker (1992), Fincher \& Smith (1994) e Braga (1997), todos relatando que quanto maior a cota altimétrica menor a produtividade da floresta. Porém discordam dos resultados obtidos por Teixeira (1987), com povoamentos de Eucalyptus spp., que verificou maior crescimento das plantas no topo do terreno, e por Courseuil \& Madruga (1998).

A distribuição do conjunto de dados com maior semelhança com a de cotas é, em ordem descrescente, ArgT, AreT, ArMG e Umi, todas elas relacionadas aos atributos físicos do solo e à fisiografia. Este cenário, evidenciando uma relação mais forte entre a produtividade do sítio e os atributos físicos do solo e a fisiografia, em detrimento dos atributos químicos, também foi observado por Ralston (1964), Barros (1974), Carmean (1975), Spurr \& Barnes (1980), Santana (1986), Schonau (1987), Teixeira (1987), Gonçalves (1990), Braga (1997), Braga et al. (1999) e Amaral (2000).

A correlação positiva entre cotas e ArgT e negativa com AreT e ArMG deve-se ao processo erosivo, que favorece o transporte e acumulação relativa das partículas maiores e mais pesadas (areia) nas cotas inferiores do terreno, o inverso do que ocorre com as partículas menores e mais leves (argila), o que também foi verificado no trabalho de Torrado (1989) e de Garcia Y Garcia (1997). Este contexto explica a correlação positiva entre cotas e umidade, pois a capacidade de armazenamento de água aumenta à medida que a textura fica mais fina, ou seja, aumentando-se os teores de areia reduz-se a capacidade de retenção de água disponível, o que também é relatado no trabalho de Garcia Y Garcia (1997).

Outras correlações importantes foram: ArMG x ArgT, ArMG x Umi, ArF x Umi, AreG x ArgT, AreT x ArgT, AreT x Umi, ArgT x Umi, concordando com Fietz (1998), relatando que a capacidade de armazenamento de água geralmente está relacionada com a composição granulométrica do solo, aumentando à medida que a textura vai diminuindo, visto que solos argilosos retêm e armazenam mais umidade que os arenosos, e com Correia (1993) e Correia et al. (1996), os quais concluem que grandes teores de areia grossa no solo podem levar àredução no armazenamento de água. 
Chama a atenção a correlação linear positiva entre MO e CTC, concordando com Grespan (1997), o qual relata que o aumento nos teores de MO contribui com o aumento da CTC, e com Santana (1986) relatando que a redução do teor de MO leva à diminuição da CTC do solo. Também chamam a atenção as correlações positivas entre $\mathrm{MO}$ e $\mathrm{Al}$ e MO e H+Al, o que segundo Santana (1986) é desejável, visto que a MO reduz o efeito negativo de altas concentrações de $\mathrm{Al}$ trocável.

Por fim, a correlação negativa $\mathrm{pH} \times \mathrm{x}$ Umi, ou seja, quanto menor a cota maior a porcentagem de areia no solo, menor a umidade, maior o $\mathrm{pH}$, ou seja, menor acidez, concorda com os resultados obtidos por Santana (1986), onde os solos dos topos e encostas se mostraram mais ácidos, com $\mathrm{pH}$ em torno de 4,5, sendo nos topos mais baixo que nas encostas, enquanto que nas baixadas o $\mathrm{pH}$ aumentou, variando entre 4,8 e 5,8.

A perda do solo superficial por erosão, que é maior nas áreas de topos e encostas que nas de baixadas, pode ser a responsável pela maior acidez na camada arável daquelas áreas. A acidez geralmente aumenta com a profundidade do solo e à medida que a profundidade do solo superficial diminui, mais subsolo é incluído na camada arável (Instituto da Potassa \& Fosfato, 1998).

\subsubsection{Regressão linear simples}

Na Tabela 6 é apresentado o resultado da análise de regressão linear simples entre a variável dependente (IS) e as independentes, quando não houve violação das suposições, e na Tabela 7 quando houve violação de alguma suposição, sendo especificada a suposição violada. Na Tabela 8 são especificadas as técnicas de correção aplicadas e os novos resultados. 
Tabela 6. Resultado da análise de regressão simples, sem violação das suposições, entre o IS e as variáveis independentes

\begin{tabular}{|c|c|c|c|}
\hline Variável Independente & nó Observações & $\mathbf{r}^{2}$ & Prob > F \\
\hline Umidade & 41 & 0,139 & $0,016 * *$ \\
\hline Manganês & 41 & 0,109 & $0,034 * *$ \\
\hline Argila Total & 41 & 0,103 & $0,039 * *$ \\
\hline Enxofre & 41 & 0,092 & $0,053^{*}$ \\
\hline Acidez Potencial & 41 & 0,090 & $0,055^{*}$ \\
\hline $\mathrm{T}$ & 41 & 0,086 & $0,062 *$ \\
\hline Cobre & 41 & 0,075 & $0,081 *$ \\
\hline Areia Total & 41 & 0,064 & 0,109 \\
\hline Areia Muito Fina & 41 & 0,057 & 0,131 \\
\hline Potássio & 41 & 0,044 & 0,187 \\
\hline Zinco & 41 & 0,039 & 0,211 \\
\hline Magnésio & 41 & 0,027 & 0,297 \\
\hline Areia Grossa & 41 & 0,027 & 0,302 \\
\hline Argila em Água & 41 & 0,021 & 0,366 \\
\hline Declividade (\%) & 41 & 0,019 & 0,378 \\
\hline CTC & 41 & 0,019 & 0,382 \\
\hline Ferro & 41 & 0,017 & 0,403 \\
\hline $\mathrm{pH}$ & 41 & 0,012 & 0,488 \\
\hline Areia Média & 41 & 0,011 & 0,513 \\
\hline Fósforo & 41 & 0,005 & 0,658 \\
\hline Face de Exposição & 41 & 0,004 & 0,662 \\
\hline Relação Silte/Argila & 41 & 0,004 & 0,692 \\
\hline Floculação & 41 & 0,000 & 0,927 \\
\hline Silte & 41 & 0,000 & 0,960 \\
\hline
\end{tabular}

** associações significativas ao nível de $5 \%$ de probabilidade $(\mathrm{P} \leq 0,05)$.

* associações significativas ao nível de $10 \%$ de probabilidade $(\mathrm{P} \leq 0,10)$. 
Tabela 7. Resultado da análise de regressão simples com violação das suposições

\begin{tabular}{cccc}
\hline Variável Inde pendente & $\mathbf{r}^{2}$ & Prob>F & Violação \\
\hline Cotas & 0,288 & $0,000^{* *}$ & Variância e Obs. Influente \\
Areia Muito Grossa & 0,069 & $0,095^{*}$ & Variância \\
Alumínio & 0,050 & 0,157 & Obs. Infl., Curvil. e Variância \\
Areia Fina & 0,030 & 0,275 & Variância \\
Boro & 0,030 & 0,279 & Obs. Influente e Curvilinear. \\
Matéria Orgância & 0,026 & 0,305 & Obs. Influente \\
Saturação por Alumínio & 0,017 & 0,417 & Obs. Influente \\
Saturação por Bases & 0,016 & 0,418 & Obs. Influente \\
Soma de Bases Trocáv. & 0,005 & 0,648 & Obs. Influente \\
Cálcio & 0,000 & 0,866 & Obs. Influente \\
\hline ** associações significativas ao nível de 5\% & $*$ associações significativas ao nível de 10\%.
\end{tabular}

Tabela 8. Resultado da análise de regressão simples com correção das violações

\begin{tabular}{cccc}
\hline Variável Independente & $\mathbf{r}^{2}$ & Prob>F & Correção \\
\hline Cotas & 0,410 & $0,000^{* *}$ & Retirada Obs. 09 \\
Alumínio & 0,140 & $0,017 * *$ & Retirada Obs. 09 \\
Matéria Orgânica & 0,094 & $0,054^{*}$ & Retirada Obs. 09 \\
Boro & 0,089 & 0,061 & Retirada Obs. 38 \\
Areia Muito Grossa & 0,061 & 0,117 & Exponete Ótimo ** 2.4 \\
Saturação por Bases & 0,037 & 0,229 & Retirada Obs. 41 \\
Saturação por Alumínio & 0,034 & 0,253 & Retirada Obs. 41 \\
Areia Fina & 0,025 & 0,322 & Exponete Ótimo ** 2.7 \\
Cálcio & 0,015 & 0,447 & Retirada Obs. 41 \\
Soma de Bases Trocáv. & 0,014 & 0,461 & Retirada Obs. 41 \\
\hline ** associações significativas ao nível de 5\% & $*$ associações significativas ao nível de 10\%.
\end{tabular}

As associações e relações causa-efeito mais fortes com IS foram encontradas, respectivamente, em ordem decrescente, para cotas, Al, Umi, Mn e ArgT. 
Somente a variável cotas explica $41 \%$ das variações do IS. Por meio da análise dos resultados obtidos, o mais provável é que a textura e a estrutura do solo estão atuando de maneira direta nesta relação.

O solo das partes mais baixas da área é menos argiloso e mais arenoso do que o das partes mais altas, determinando maior porosidade daquele, beneficiando o crescimento do eucalipto, visto que confere melhor aeração ao solo, suprimento mais adequado de oxigênio às raízes, remoção de maiores teores de gás carbônico liberados pelo processo respiratório das raízes e dos organismos que vivem no solo, e melhores condições para as trocas gasosas entre o ar atmosférico e o ar do solo.

Também determina maior permeabilidade e, conseqüentemente, melhores condições de drenagem, o que facilita a penetração das águas de chuvas pouco intensas e reduz a perda de água por evaporação.

Esse cenário facilita o crescimento radicular e, conseqüentemente, exploração de maior volume de solo, fazendo com que a planta atinja reservas hídricas e de nutrientes mais profundas e distantes, facilitando a extração de água e nutrientes em horizontes mais profundos que de $0-20 \mathrm{~cm}$.

Essas constatações já foram colocadas por Strothmann (1960), Barros (1974), Nambiar (1984), Sands \& Mulligan (1990), Schonau \& Aldworth (1991), Shorter (1993) e Grespan (1997).

Outro fator considerado é que as áreas de topo na região do Vale do Paraíba, Estado de São Paulo apresentam profundidade efetiva do solo menor que as áreas de baixada, o que também foi observado por Resende (1985) e Fabres et al. (1987) em outras regiões do Brasil. Isso influencia de forma negativa o suprimento de água disponível à planta, assim como o livre crescimento do sistema radicular, uma vez que as camadas de impedimento dificultam a penetração das raízes no solo, reduzindo a absorção de água e de nutrientes das camadas subsuperfíciais do solo, o que também já foi relatado por Goor (1965a), Barros (1974), Hoogh \& Dietrich (1979), Santana (1986), Cardenas (1987), Fabres et al. (1987), Teixeira (1987), Gonçalves (1990), Shorter (1993), Melo (1994) e Amaral (2000).

Também se destaca a variável Al trocável, que explica 14\% das variações do IS, 
concordando com Thonson \& Mccomb (1962) e Goor \& Nascimento (1969), os quais relatam que altas concentrações de alumínio geralmente provocam decréscimo no crescimento em altura. Esse fato poderia estar associado à redução no desenvolvimento e funcionamento do sistema radicular pelo efeito tóxico do alumínio, principalmente em solos ácidos com $\mathrm{pH}$ abaixo de 5,0, onde a solubilidade do alumínio aumenta rapidamente, ocasionando baixa eficiência na absorção de nutrientes e reduções na capacidade de exploração do solo, o que já foi relatado por Fanquim \& Vale (1991) e Gomes (2001), assim como por Mccool (1969), Malavolta (1980), Foy (1984, 1988 e 1992), Marschner (1986), Bueno (1987) e Braccini et al. (1998), que chamam a atenção quanto a influência do alumínio na inibição na absorção de nutrientes essenciais, como $\mathrm{Ca}, \mathrm{K}, \mathrm{Mg}$ e $\mathrm{P}$.

Importante lembrar que o valor de $\mathrm{pH}$ encontrado nas amostras de solo analisadas nesse estudo variou de 3,3 a 3,9, ou seja, solos extremamente ácidos, e o teor de $\mathrm{Al}$ variou de 15-32 mmolc. $\mathrm{dm}^{-3}$, sendo que Bueno (1987) observou o efeito de toxidade ao alumínio no crescimento de Hevea brasiliensis apenas em concentrações superiores a 15 mmolc.dm ${ }^{-3}$.

Segundo tabela apresentada por Fanquin \& Vale (1991), com dados de Neves et al. (1982b), o nível crítico de porcentagem de saturação por alumínio no solo para eucalipto é de $88 \%$. Nesse trabalho os valores de $\mathrm{m} \%$ variam de $81-93 \%$ e de V\% entre $1-5 \%$, ou seja, solos extremamente álicos e distróficos.

Os resultados do trabalho de Neves et al. (1982a) indicam que E. grandis em solução nutritiva apresentou redução contínua de altura, de peso de matéria seca total (raízes e parte aérea), de Ca na parte aérea, assim como de $\mathrm{Ca}$ e $\mathrm{Mg}$ na raíz, conforme aumento dos teores de alumínio no solo $\left(0,3,9,27\right.$ e 81 mmolc.dm $^{-3}$ respectivamente). Apesar do aumento das concentrações de alumínio de 0 para 9 mmolc. $\mathrm{dm}^{-3}$ ter acarretado reduções dos parâmetros de crescimento das plantas (altura, raízes e matéria seca) de todas as espécies (E. cloeziana, E. grandis, E. paniculata e E. urophylla), deve-se considerar que mesmo para a espécie mais sensível, nessa maior concentração de alumínio, o crescimento ainda foi apreciável.

Porém essas constatações chocam com os resultados e conclusões encontrados na 
literatura, afirmando que as espécies do gênero Eucalyptus apresentam alta tolerância ao alumínio, apresentando bons níveis de produtividade em solos ácidos e álicos, não respondendo à correção do $\mathrm{pH}$ por meio de calagem, o que em parte já foi relatado por Neves (1983), Neves et al. (1982a, 1982b e 1990), Gonçalves et al. (1986), Barros et al. (1990b); Novais et al. (1990) e Gomes (2001).

Nesse caso, o alumínio pode não ser restritivo ao crescimento do eucalipto, que parece mais condicionado pelos menores teores de bases trocáveis que as áreas com menor IS apresentam em relação às áreas com maior IS, o que é indicado pelos valores do coeficiente de correlação entre SB, V\%, Mg e K com IS.

Analisando os coeficientes de correlação nota-se que os solos do topo, com menor IS, apresenta maior valor para $\mathrm{H}+\mathrm{Al}, \mathrm{Al}$ e $\mathrm{m} \%$ e menores valores para $\mathrm{SB}, \mathrm{V} \%, \mathrm{Mg}$ e $\mathrm{K}$ quando comparados aos solos das baixadas, com maior IS, o que pode ser explicado por Alvarez et al. (1996) e Ribeiro et al. (1996), relatando que com a lixiviação ocorre a substituição das bases trocáveis por cátions ácidos $\left(\mathrm{H}^{+}\right.$e $\left.\mathrm{Al}^{3+}\right)$ no complexo de troca do solo, com isso menor parte da CTC é ocupada por cátions básicos. Conseqüentemente ocorre o aumento da acidez, sendo que o cátion que acaba predominando no complexo é o $\mathrm{Al}^{3+}$, o que é afirmado pela expressiva participação dos valores de acidez potencial e alumínio trocável respectivamente, no calculo dos valores de T e CTC.

Portanto, as variações dos valores obtidos para CTC e T na área de estudo estão diretamente relacionadas às diferentes concentrações de $\mathrm{Al}$ e $\mathrm{H}+\mathrm{Al}$ encontradas, o que explica os coeficientes de correlação positivos entre T e CTC com cotas e negativos com IS.

É notório na área de estudo que o processo de erosão laminar e lixiviação é mais intenso nos solos dos topos e das encostas que nos das baixadas, devido à ação da declividade do terreno no escoamento superficial e subsuperficial, favorecendo o carreamento e deposição das bases trocáveis nas áreas mais baixas, o que também ocorre por meio do processo de percolação das águas pluviais.

A umidade também explica cerca de $14 \%$ das variações do IS e ArgT 10,3\%, concordando com o colocado por Carmo et al. (1990), que o excesso de água no sistema implica na redução de oxigênio e aeração deficiente no solo, tornando o ambiente pouco 
adequado ao desenvolvimento e crescimento do sistema radicular do eucalipto, assim como o excesso de partículas finas no solo, o que é relatado por Della-Bianca \& Olson (1961), Jackson (1962), Ralston (1964), Hannah (1968a, 1968b e 1971), Broadfoot (1969) e Shorter (1993).

Soma-se a isso o observado por Santana (1986) sobre a relação negativa entre solos muito argilosos e crescimento de E. saligna, devido à dificuldade de drenagem desse solo. Barros (1974) ambém encontrou associação negativa entre disponibilidade de água no solo, na profundidade de 0-20 cm, e altura do eucalipto.

Ao contrário do constatado, esperava-se uma relação positiva entre umidade no solo e IS, obedecendo assim a um conceito geral de que o eucalipto é exigente quanto à água. Deve-se ressaltar que os valores de umidade coletados, no mês de dezembro, não indicam que durante todas as épocas do ano o suprimento de água disponível à planta corresponde a estes valores.

Também se deve levar em conta que, apesar dos solos argilosos possuírem maior capacidade de retenção de água que os solos arenosos, a maior parte dessa água não está disponível para as plantas (Instituto da Potassa \& Fosfato, 1998). Os solos argilosos retêm mais fortemente a água que os solos arenosos, ou seja, menos água disponível.

O mais provável é que nos períodos de estiagem mais longa e/ou de menor precipitação pluviométrica (entre os meses de junho e agosto) ocorra deficiência de umidade nas áreas mais declivosas próximas aos topos, em razão da ação gravitacional sobre a água, da dificuldade de penetração das águas de chuvas pouco intensas, da maior perda de água no solo por evaporação e da menor profundidade efetiva do solo.

Nesse caso, nas áreas de pequena declividade próximas às baixadas o suprimento de água disponível à planta deve ser maior, principalmente nas camadas subsuperfíciais do solo, facilitando o transporte de nutrientes no solo pelos mecanismos de massa e difusão e beneficiando a transferência e absorção de nutrientes do solo para a planta, determinando maior crescimento do eucalipto.

O manganês explicou 10,9\% das variações do IS. Liani (1966) e Brum (1979) relatam a relação positiva entre crescimento das árvores e teor de manganês no solo, o que é afirmado por Bellote (1979), constatando que o manganês é o micronutriente mais 
extraído pela planta, o que pode ser explicado por Fanquim \& Vale (1991), os quais relatam a importância desse micronutriente para as plantas e sua disponibilidade em solos ácidos como o desse estudo.

\subsubsection{Regressão linear múltipla}

A seguir são apresentados os resultados da análise de regressão linear múltipla entre a variável dependente (IS) e as independentes, com o conjunto de dados completo, sem as observações excessivamente influentes.

No processo de redução do número de variáveis explicativas a serem consideradas no ajuste do modelo de regressão, o procedimento passo-a-passo adicionou, em ordem descrescente, as seguintes variáveis ao modelo: Cot, Flo, Zn, P, Mn, Umi, Ca, $\mathrm{S}, \mathrm{ArF}, \mathrm{pH}, \mathrm{ArMF}, \mathrm{K}$, Face, ArMG, V, SilAr, Al e T.

Posteriormente foi aplicado o método todas as regressões possíveis ("adjrsquare"), no conjunto de dados inicial (com todas as variáveis) e no sub-conjunto de variáveis explicativas obtido com o método passo-a-passo, o que possibilitou selecionar dois modelos de regressão para apresentação (Tabelas 9 e 10).

Tabela 9. Análise de variância do $1^{\circ} \underline{-}$ modelo de regressão múltipla selecionado

\begin{tabular}{clllc}
\hline CV & GL & SQ & QM & Prob $>\mathrm{F}$ \\
\hline${ }^{(1)}$ Modelo & 11 & 127,8 & 11,61 & 0,00 \\
Resíduo & 27 & 42,63 & 1,579 & \\
Total & 38 & 170,4 & & \\
${ }^{(1)} \mathrm{R}^{2}=0,65$ & $\mathrm{CV}=4,1$ & $\mathrm{Pr}<\mathrm{W}=0,29$ & n. ${ }^{-}$variáveis=11 & \\
& & & \\
$\mathrm{IS}=136,7-0,098 *$ Cot+0,836*P+2,524*K-0,101*S-1,046*V-10,12*Zn+0,850*Mn- &
\end{tabular}

$\mathrm{O}$ resultado de $\mathrm{F}(\operatorname{Pr}>\mathrm{F})$ menor que 0,01 permite aceitar, a $1 \%$ de significância, 
HA - existe relação de dependência entre as variáveis. Este valor também permitiu rejeitar H0 - não há relação de dependência entre as variáveis, concluindo que há fortes evidências estatísticas de que existe relação causa-efeito entre a variável dependente e a(s) independente(s).

$\mathrm{O}$ valor obtido para o $\mathrm{R}^{2}$ permitiu concluir que o modelo ajustado explicou $65 \%$ das variações do IS e o resíduo explicou 35\%, ou seja, as diferenças existentes entre os valores das variáveis independentes inclusas no modelo tiveram maior influência nas variações do IS, do que o resíduo. De acordo com Carmean (1975), normalmente os trabalhos mais bem sucedidos de relação solo-sítio explicam entre $65 \%$ e $85 \%$ da variação do crescimento da floresta.

Do total de variação dos dados (SQT=170,4), o modelo ajustado explicou ( $\mathrm{SQM}=127,8)$ enquanto que o resíduo $(\mathrm{SQR}=42,63)$.

A comparação entre o valor do $(\mathrm{QMM}=11,61)$ e do $(\mathrm{QMR}=1,579)$ comprovam que as variações do IS não são conseqüência do acaso (resíduo) e podem ser explicadas pelas diferenças existentes entre os valores das variáveis independentes incluídas no modelo.

O valor obtido para $(\mathrm{CV}=4,1)$ foi excelente, considerando que para dados provindos do campo é aceito um valor de (CV até 30,0).

Tabela 10. Análise de variância do $2^{\circ}$ modelo de regressão múltipla selecionado

\begin{tabular}{ccccc}
\hline CV & GL & SQ & QM & Prob $>$ F \\
\hline${ }^{(1)}$ Modelo & 9 & 120,5 & 13,39 & 0,00 \\
Resíduo & 29 & 49,86 & 1,719 & \\
Total & 38 & 170,4 & & \\
${ }^{(1)} \mathrm{R}^{2}=0,616$ & $\mathrm{CV}=4,3$ & $\operatorname{Pr}<\mathrm{W}=0,064$ & n. ${ }^{\circ}$ variáveis=9
\end{tabular}

$\mathrm{IS}=128.7-0.095 * \mathrm{Cot}+0.938 * \mathrm{P}+2.198 * \mathrm{~K}-0.078 * \mathrm{Al}-1.089 * \mathrm{~V}-8.999 * \mathrm{Zn}+0.808 * \mathrm{Mn}+$ $8.725 *$ SilArg $0.299 *$ Umi. 


\subsection{Estatística espacial}

\subsubsection{Resumo estatístico e análise exploratória dos dados}

Na Tabela 11 são apresentados os valores obtidos para as medidas estatísticas dos atributos do relevo, do solo e da planta. 
Tabela 11. Resumo estatístico

\begin{tabular}{|c|c|c|c|c|c|c|c|c|c|c|c|c|c|c|c|c|c|}
\hline Var & Méd & Medn & Mín & Máx & LI & $\mathbf{L S}$ & $\mathbf{Q I}$ & $\mathbf{Q S}$ & Vari & $\overline{A T}$ & A I & $\mathrm{CV}$ & DP & $\mathbf{C S}$ & $\mathrm{CC}$ & $\mathbf{W}$ & $\mathbf{K S}$ \\
\hline${ }^{2} \operatorname{Cot}$ & 965,3 & 965,7 & 940,2 & 998,2 & 916,1 & 1010 & 951,6 & 975,2 & 248,9 & 57,9 & 23,6 & 1,63 & 15,7 & 0,30 & $-0,59$ & $0,212^{*}$ & $0,057 * *$ \\
\hline${ }^{2}$ IS & 30,49 & 30,77 & 25,46 & 34,15 & 23,99 & 36,92 & 28,84 & 32,08 & 4,45 & 8,68 & 3,23 & 6,92 & 2,11 & $-0,31$ & $-0,61$ & $0,422 *$ & $0,080^{* *}$ \\
\hline $\mathrm{pH}$ & 3,67 & 3,7 & 3,3 & 3,9 & 3,37 & 3,97 & 3,6 & 3,75 & 0,01 & 0,6 & 0,15 & 3,48 & 0,12 & $-0,49$ & 0,58 & $0,014 *$ & $0,209 * *$ \\
\hline${ }^{3} \mathrm{MO}$ & 31,04 & 31 & 23 & 44 & 22 & 38 & 28 & 32 & 18,39 & 21 & 4 & 13,8 & 4,28 & 0,81 & 1,16 & $0,094 *$ & $0,168^{* *}$ \\
\hline${ }^{4} \mathrm{P}$ & 4,48 & 5 & 2 & 8 & 2,5 & 6,5 & 4 & 5 & 1,60 & 6 & 1 & 28,2 & 1,26 & 0,29 & 0,48 & 0,035 & $0,172 * *$ \\
\hline${ }^{4} \mathrm{~S}$ & 15,97 & 16 & 9 & 25 & 0,5 & 28,5 & 11 & 18 & 21,3 & 16 & 7 & 28,9 & 4,62 & 0,28 & $-0,97$ & 0,011 & $0,151^{* *}$ \\
\hline${ }^{5} \mathrm{~K}$ & 0,44 & 0,4 & 0,1 & 1 & 0 & 1,45 & 0,2 & 0,7 & 0,08 & 0,9 & 0,5 & 63,7 & 0,28 & 0,27 & $-1,21$ & 0,001 & $0,171^{* *}$ \\
\hline${ }^{5} \mathrm{Ca}$ & 1,53 & 1 & 1 & 18 & 1 & 1 & 1 & 1 & 7,05 & 17 & 0 & 172 & 2,65 & 6,25 & 39,6 & 0,000 & 0,433 \\
\hline${ }^{5} \mathrm{Mg}$ & 1,29 & 1 & 1 & 2 & 0 & 3,5 & 1 & 2 & 0,21 & 1 & 1 & 35,6 & 0,46 & 0,94 & 1,16 & 0,000 & 0,444 \\
\hline${ }^{5} \mathrm{Al}$ & 20,46 & 20 & 14 & 32 & 12 & 28 & 18 & 22 & 14,9 & 18 & 4 & 18,8 & 3,86 & 1,10 & 1,47 & $0,051^{*}$ & $0,206^{* *}$ \\
\hline $\mathrm{H}+\mathrm{Al}$ & 117,6 & 109 & 80 & 205 & 42,5 & 190,5 & 98 & 135 & 744,4 & 125 & 37 & 23,1 & 27,2 & 0,97 & 0,97 & 0,001 & $0,209 * *$ \\
\hline${ }^{5} \mathrm{SB}$ & 3,27 & 2,7 & 2,1 & 20,4 & 0,7 & 4,7 & 2,2 & 3,2 & 8,09 & 18,3 & 1 & 86,9 & 2,84 & 5,71 & 34,9 & 0,000 & 0,340 \\
\hline${ }^{5} \mathrm{~T}$ & 120,8 & 111,7 & 82,7 & 207,1 & 43,42 & 194,8 & 100,2 & 138,0 & 746,3 & 124 & 37,8 & 22,6 & 27,3 & 0,91 & 0,78 & 0,002 & $0,191^{* *}$ \\
\hline${ }^{5} \mathrm{CTC}$ & 23,73 & 22,4 & 16,7 & 40,4 & 13,65 & 32,45 & 20,7 & 25,4 & 22,13 & 23,7 & 4,7 & 19,8 & 4,70 & 1,51 & 3,24 & 0,000 & $0,164 * *$ \\
\hline${ }^{6} \mathrm{~V}$ & 2,73 & 2 & 1 & 14 & 0,5 & 4,5 & 2 & 3 & 4,20 & 13 & 1 & 75,0 & 2,04 & 4,37 & 23,4 & 0,000 & 0,277 \\
\hline${ }^{6} \mathrm{~m}$ & 86,58 & 88 & 50 & 93 & 77,5 & 97,5 & 85 & 90 & 46,04 & 43 & 5 & 7,83 & 6,78 & $-4,07$ & 21,4 & 0,000 & $0,188 * *$ \\
\hline${ }^{4} \mathrm{~B}$ & 0,58 & 0,59 & 0,34 & 0,77 & 0,29 & 0,87 & 0,51 & 0,65 & 0,01 & 0,43 & 0,14 & 17,4 & 0,10 & $-0,20$ & $-0,44$ & $0,722 *$ & $0,092 * *$ \\
\hline${ }^{4} \mathrm{Cu}$ & 0,55 & 0,4 & 0 & 1,5 & 0 & 1,45 & 0,2 & 0,7 & 0,19 & 1,5 & 0,5 & 78,4 & 0,43 & 0,72 & $-0,54$ & 0,001 & $0,153^{* *}$ \\
\hline
\end{tabular}


Tabela 11. Resumo estatístico

\begin{tabular}{cccccccccccccccccc}
\hline${ }^{1}$ Var & Méd & Medn & Mín & Máx & LI & LS & QI & QS & Vari & AT & AI & CV & DP & CS & CC & W & KS \\
\hline${ }^{4} \mathrm{Fe}$ & 176,4 & 169 & 63 & 380 & 0 & 387 & 102 & 216 & 5825 & 317 & 114 & 43,2 & 76,3 & 0,68 & $-0,01$ & $0,074^{*}$ & $0,101^{* *}$ \\
${ }^{4} \mathrm{Mn}$ & 1,31 & 1 & 0,2 & 6 & 0 & 3,35 & 0,6 & 1,7 & 1,43 & 5,8 & 1,1 & 91,3 & 1,19 & 2,15 & 5,55 & 0,000 & $0,195^{* *}$ \\
${ }^{4} \mathrm{Zn}$ & 0,42 & 0,40 & 0,2 & 0,9 & 0 & 0,8 & 0,3 & 0,5 & 0,02 & 0,7 & 0,2 & 40,2 & 0,17 & 1,08 & 0,76 & 0,000 & $0,244^{* *}$ \\
${ }^{6} \mathrm{ArMG}$ & 4,04 & 3 & 1 & 9 & 0 & 12 & 2 & 6 & 6,19 & 8 & 4 & 61,4 & 2,48 & 0,65 & $-0,78$ & 0,000 & $0,224^{* *}$ \\
${ }^{6} \mathrm{AreG}$ & 16,34 & 16 & 10 & 22 & 8 & 24 & 14 & 18 & 8,08 & 12 & 4 & 17,3 & 2,84 & $-0,12$ & 0,31 & $0,214^{*}$ & $0,115^{* *}$ \\
${ }^{6} \mathrm{ArM}$ & 14,51 & 14 & 12 & 22 & 10 & 18 & 13 & 15 & 4,05 & 10 & 2 & 13,8 & 2,01 & 1,62 & 3,83 & 0,000 & $0,234^{* *}$ \\
${ }^{6} \mathrm{ArF}$ & 14,56 & 15 & 10 & 21 & 8,5 & 20,5 & 13 & 16 & 6,10 & 11 & 3 & 16,9 & 2,47 & 0,25 & $-0,15$ & $0,424^{*}$ & $0,102^{* *}$ \\
${ }^{6} \mathrm{AMF}$ & 2,19 & 2 & 1 & 4 & 0 & 6 & 1 & 3 & 1,06 & 3 & 2 & 46,9 & 1,03 & 0,30 & $-1,06$ & 0,000 & $0,194^{* *}$ \\
${ }^{6} \mathrm{AreT}$ & 51,65 & 53 & 39 & 63 & 35 & 67 & 47 & 55 & 39,43 & 24 & 8 & 12,1 & 6,27 & $-0,38$ & $-0,54$ & $0,158^{*}$ & $0,121^{* *}$ \\
${ }^{6} \mathrm{Silt}$ & 6,46 & 6 & 2 & 15 & 0 & 14 & 4 & 8 & 8,15 & 13 & 4 & 44,1 & 2,85 & 0,68 & 0,54 & 0,016 & $0,171^{* *}$ \\
${ }^{6} \mathrm{ArgT}$ & 41,87 & 41 & 33 & 52 & 30 & 54 & 39 & 45 & 23,7 & 19 & 6 & 11,6 & 4,86 & 0,51 & $-0,44$ & 0,042 & $0,137^{* *}$ \\
${ }^{6} \mathrm{ArgA}$ & 22,87 & 23 & 14 & 36 & 6,75 & 36,75 & 18 & 25,5 & 30,45 & 22 & 7,5 & 24,1 & 5,51 & 0,24 & $-0,51$ & $0,209^{*}$ & $0,113^{* *}$ \\
${ }^{6} \mathrm{Floc}$ & 44,75 & 45 & 19 & 72 & 3 & 83 & 33 & 53 & 190,7 & 53 & 20 & 30,8 & 13,8 & 0,00 & $-0,62$ & $0,479^{*}$ & $0,086^{* *}$ \\
SilAr & 0,15 & 0,15 & 0,03 & 0,34 & 0 & 0,32 & 0,10 & 0,19 & 0,004 & 0,30 & 0,09 & 41,7 & 0,06 & 0,57 & 0,49 & $0,487^{*}$ & $0,085^{* *}$ \\
${ }^{6} \mathrm{Umi}$ & 20,54 & 20,31 & 15,14 & 30,09 & 10,72 & 29,90 & 17,92 & 22,71 & 11,64 & 14,9 & 4,79 & 16,6 & 3,41 & 0,49 & $-0,04$ & $0,223^{*}$ & $0,095^{* *}$ \\
\hline
\end{tabular}

* significativo ao nível de $5 \%$ de probabilidade $(\mathrm{P} \geq 0,05) . \quad$ ** significativo pelo teste de Kolmogorov-Smirnov.

${ }^{1}$ variável (Var); média (Méd); mediana (Medn); valor mínimo (Mín); valor máximo (Máx); limite inferior (LI); limite superior (LS); quartil inferior (QI); quartil superior (QS); variância (Vari); amplitude total (AT); amplitude interquartílica (AT); coeficiente de variação (CV); desvio-padrão (DP); coeficiente de simetria (CS); coeficiente de curtose (CC); teste de Shapiro-Wilk (W); teste de Kolmogorov-Smirnov (KS).

Unidades: ${ }^{2}$ (metros) $;^{3}\left(\mathrm{~g} \mathrm{dm}^{-3}\right) ;{ }^{4}\left(\mathrm{mg} \mathrm{dm}^{-3}\right) ;^{5}\left(\operatorname{mmolc~dm}{ }^{-3}\right) ;{ }^{6}(\%)$. 
As variáveis Cot, IS, MO, Al, B, Fe, AreG, ArF, AreT, ArgA, Floc, SilAr e Umi apresentaram distribuição de frequiência normal, a $5 \%$ de significância, visto que o valor da Prob<W (W) é maior que 0,05 . Pelo teste KS, que ao contrário do teste $\mathrm{W}$, não é paramétrico, portanto mais robusto e menos exigente, foi constatado que além destas variáveis, pH, P, S, K, H+Al, T, m\%, CTC, Cu, Mn, Zn, ArMG, ArM, ArMF, Sil, ArgT, também apresentam distribuição de frequiência normal. Obtiveram distribuição normal para os teores de argila (Nielsen et al., 1973; Salviano, 1996; Camargo, 1997; Garcia Y Garcia, 1997; Pocay, 2000), areia (Nielsen et al., 1973; Salviano, 1996; Garcia Y Garcia, 1997 e Jakob et al., 1999), silte (Salviano, 1996; Garcia Y Garcia, 1997 e Jakob et al., 1999) e umidade (Nielsen et al., 1973). Com base no valor de d (KS), apresentado na Tabela 12, e no número de observações, no caso 41, pode-se, conforme Campos (1979), rejeitar ou admitir a hipótese de distribuição uniforme, ou não, dos dados, a um determinado valor de significância $(\alpha)$.

Tabela 12. Valores do teste de Kolmogorov-Smirnov

\begin{tabular}{ccccccc}
\hline Número de unidades amostrais / valor de $\boldsymbol{\alpha}$ & $\mathbf{0 , 2 0}$ & $\mathbf{0 , 1 0}$ & $\mathbf{0 , 0 5}$ & $\mathbf{0 , 0 2}$ & $\mathbf{0 , 0 1}$ \\
\hline 39 & 0,168 & 0,191 & 0,213 & 0,238 & 0,255 \\
40 & 0,165 & 0,189 & 0,210 & 0,235 & 0,252 \\
41 & 0,163 & 0,187 & 0,208 & 0,232 & 0,249
\end{tabular}

Fonte: Campos (1979).

Como os valores de d (KS) para Ca, $\mathrm{Mg}, \mathrm{SB}$ e V\%, apresentados na Tabela 12, estão além de 0,249 , considera-se que a distribuição destas variáveis não é normal. Sendo assim, foi testada a possível distribuição log normal destas variáveis, o que foi confirmado apenas para SB, cujo valor de d foi 0,208. Pocay (2000) também encontrou distribuição log-normal para SB.

Pode-se constatar que os valores da média e da mediana para $\mathrm{Ca}, \mathrm{V} \%$ e $\mathrm{Mg}$ não são próximos, sendo o valor da média maior que o da mediana 1,53, 1,36 e 1,29 vez em cada qual, respectivamente. Porém, nota-se que algumas variáveis cuja normalidade dos dados foi confirmada pelos testes estatísticos, apresentam média e mediana com valores 
também significativamente distantes, como $\mathrm{Cu}$ e $\mathrm{ArMG}$, sendo o valor da média maior que o da mediana 1,37 e 1,34 vez em cada qual, respectivamente. Este fato evidencia a necessidade de se levar em conta o maior número possível de parâmetros matemáticos e estatísticos para analisar o possível ajuste dos dados a distribuição normal.

Observando os gráficos de probabilidade normal, para Cu e ArMG (Figuras 7 e 8) nota-se uma tendência de aderência dos pontos à reta, indicando que a distribuição se aproxima bastante da normal. O mesmo não se pode dizer para Ca e V\% (Figuras 9 e 10).

Gráfico de Probabilidade Normal

Cobre
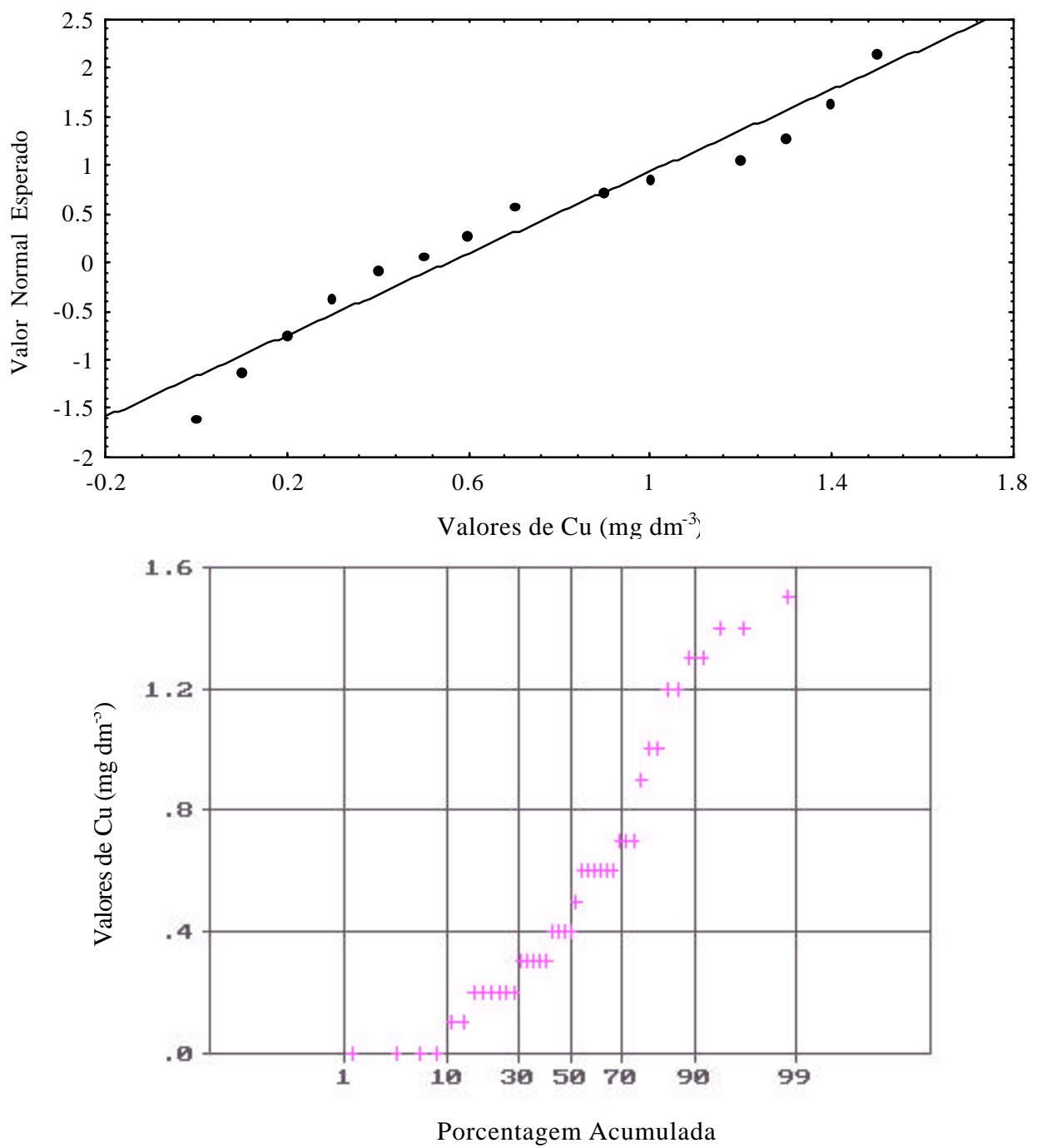

Figura 7 - Gráficos de probabilidade normal para $\mathrm{Cu}$ 
Gráfico de Probabilidade Normal

Areia Muito Grossa
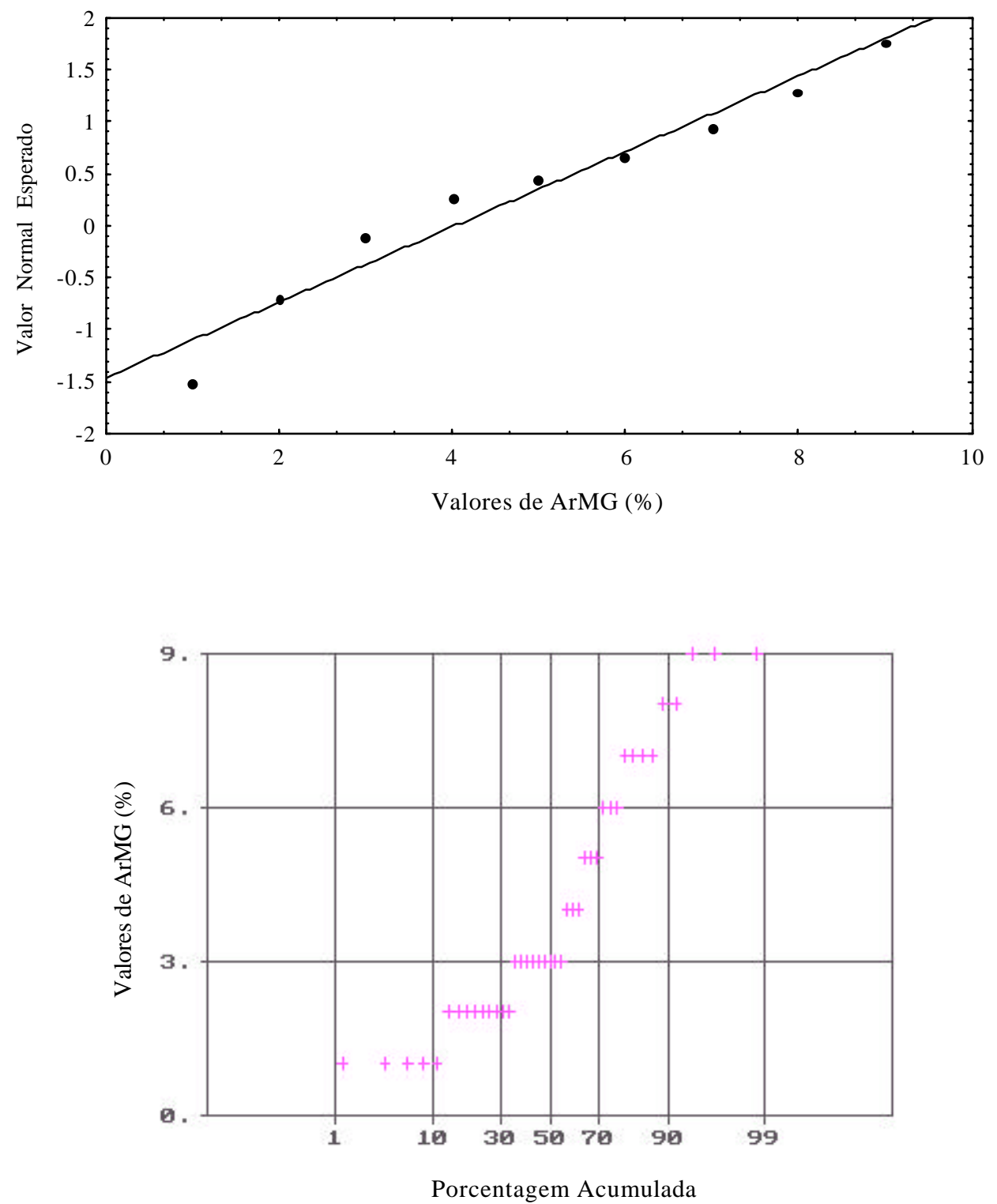

Figura 8 - Gráficos de probabilidade normal para ArMG 
Gráfico de Probabilidade Normal

Cálcio
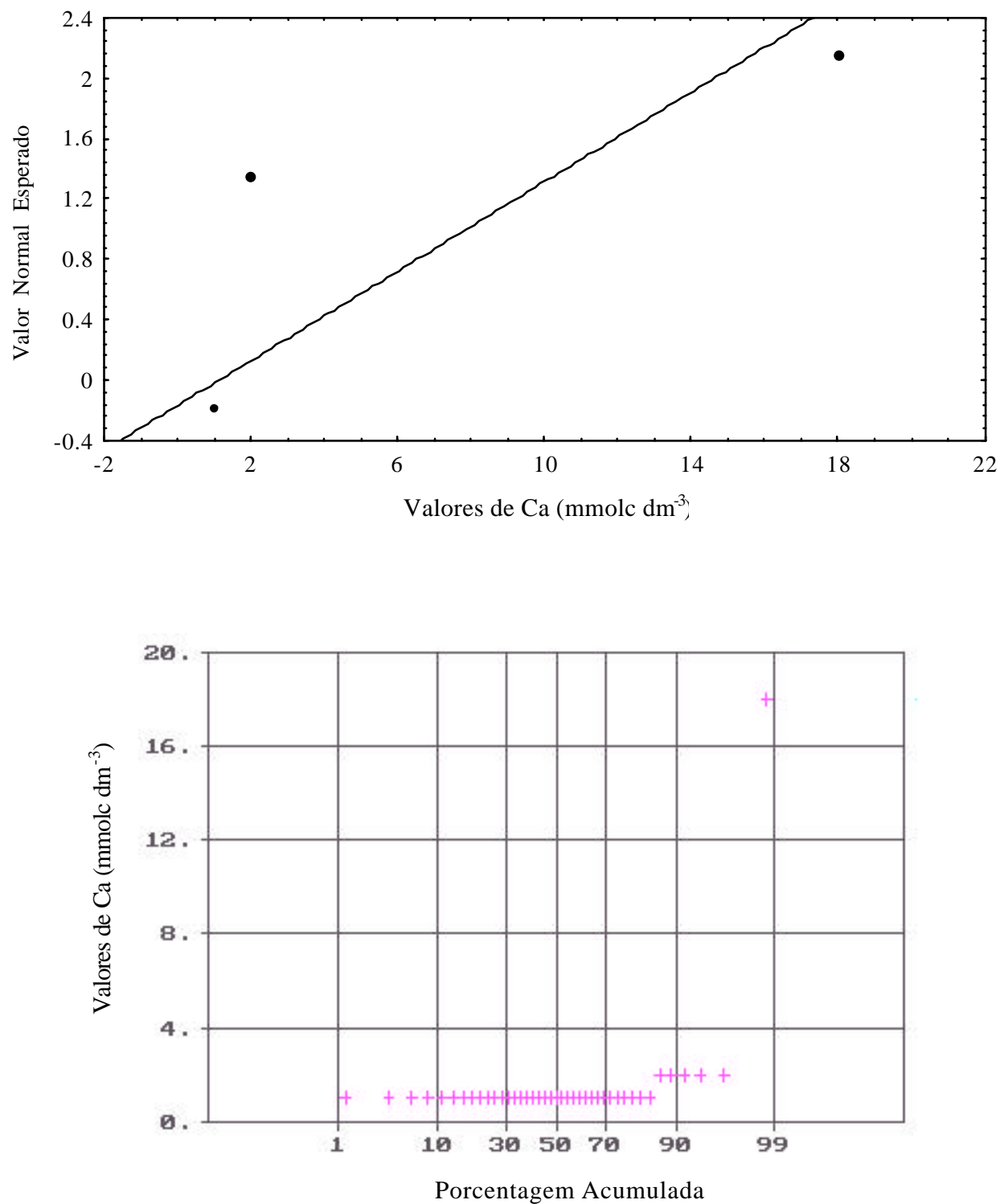

Figura 9 - Gráficos de probabilidade normal para $\mathrm{Ca}$ 
$\mathrm{V} \%$
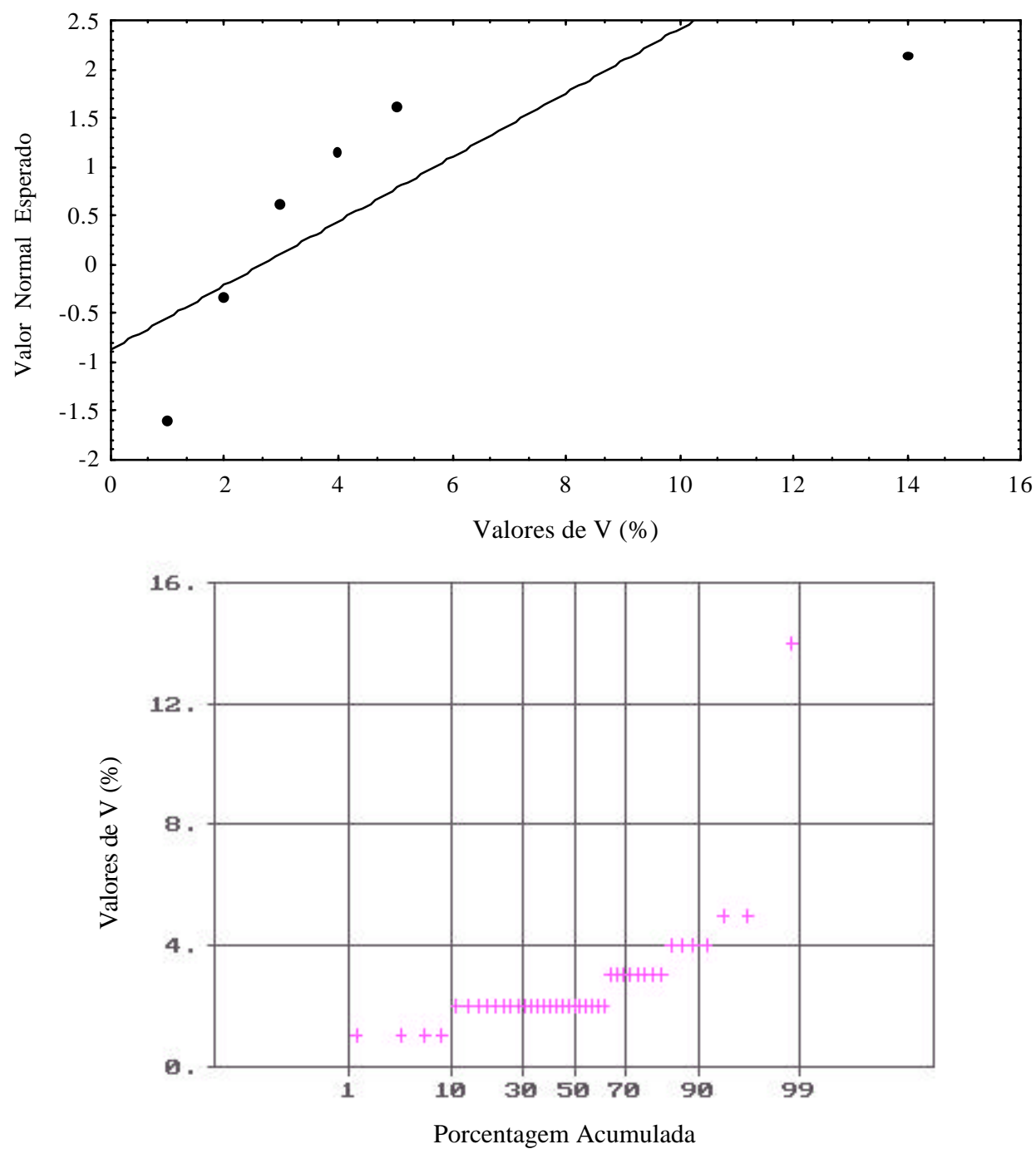

Figura 10 - Gráficos de probabilidade normal para V\%

Pelo histograma de probabilidade normal (Figura 11) pode-se confirmar a rejeição da hipótese de distribuição normal para $\mathrm{Mg}$, pois a média aritmética é uma medida bastante influenciada pelos valores extremos, não sendo uma medida de tendência central adequada para a representação dos dados, ao contrário do que ocorre para as variáveis que pelo teste W e KS apresentaram distribuição normal, como Boro (Figura 11). 

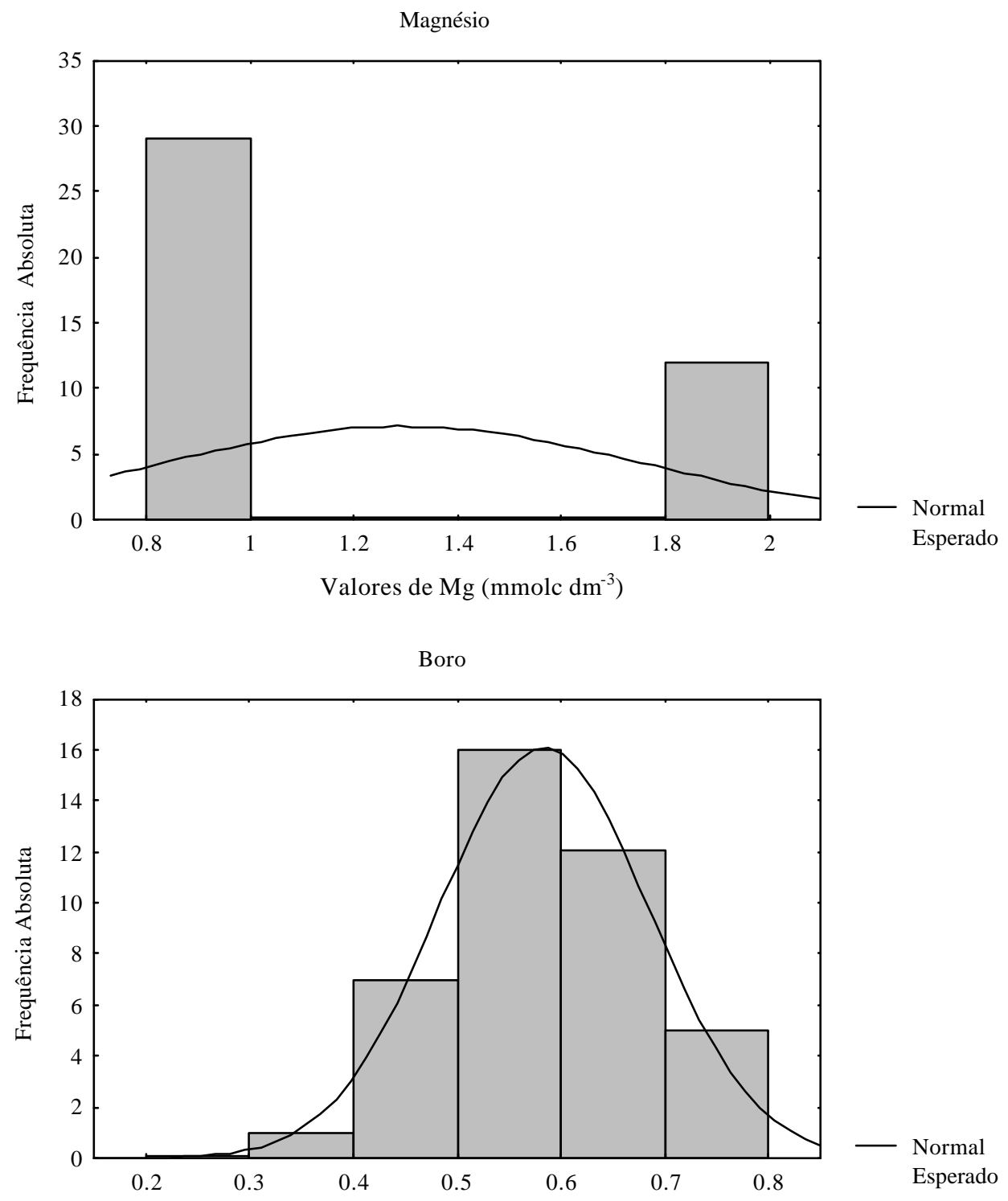

Valores de B $\left(\mathrm{mg} \mathrm{dm}^{-3}\right)$

Figura 11 - Histograma de probabilidade normal para Mg e B

A análise dos valores do coeficiente de assimetria indica que a curva de distribuição de freqüência das variáveis $\mathrm{Ca}, \mathrm{SB}, \mathrm{V} \%$ e Mn (Figura 13) possui um ramo mais longo à direita, em direção a valores mais positivos, ou seja, assimetria positiva, maior frequiência de valores baixos. Já com m\% ocorre o inverso, ou seja, assimetria negativa (Figura 12). Em ambas as variáveis estes valores são exagerados, indicando que 
estes dados não seguem perfeitamente a curva de distribuição normal, visto que não estão no intervalo de +2 a -2 . Em uma distribuição com assimetria positiva, a média é maior que a mediana e esta é maior que a moda. Se a assimetria for negativa, a média será menor que a mediana e esta menor que a moda. Nas curvas simétricas, tanto média, quanto mediana e moda são coincidentes (Assis et al., 1996). Os valores do coeficiente de curtose apontam que as variáveis $\mathrm{Ca}, \mathrm{SB}, \mathrm{V} \%, \mathrm{~m} \%, \mathrm{CTC}, \mathrm{Mn}$ e ArM apresentam distribuição leptocúrtica, com valores excessivamente exagerados, além de +2 .
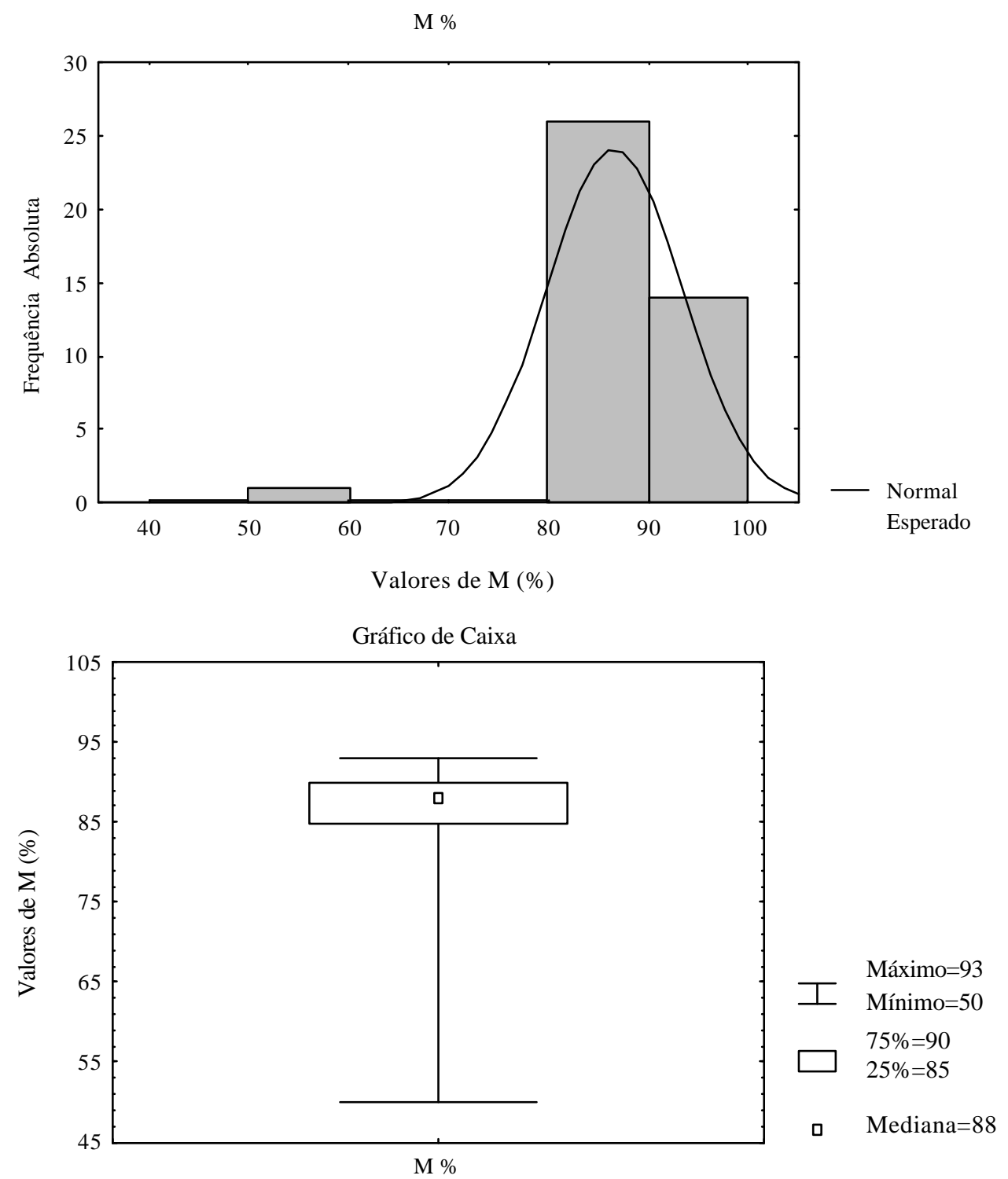

Figura 12 - Histograma de probabilidade normal e gráfico de caixa para m\% 

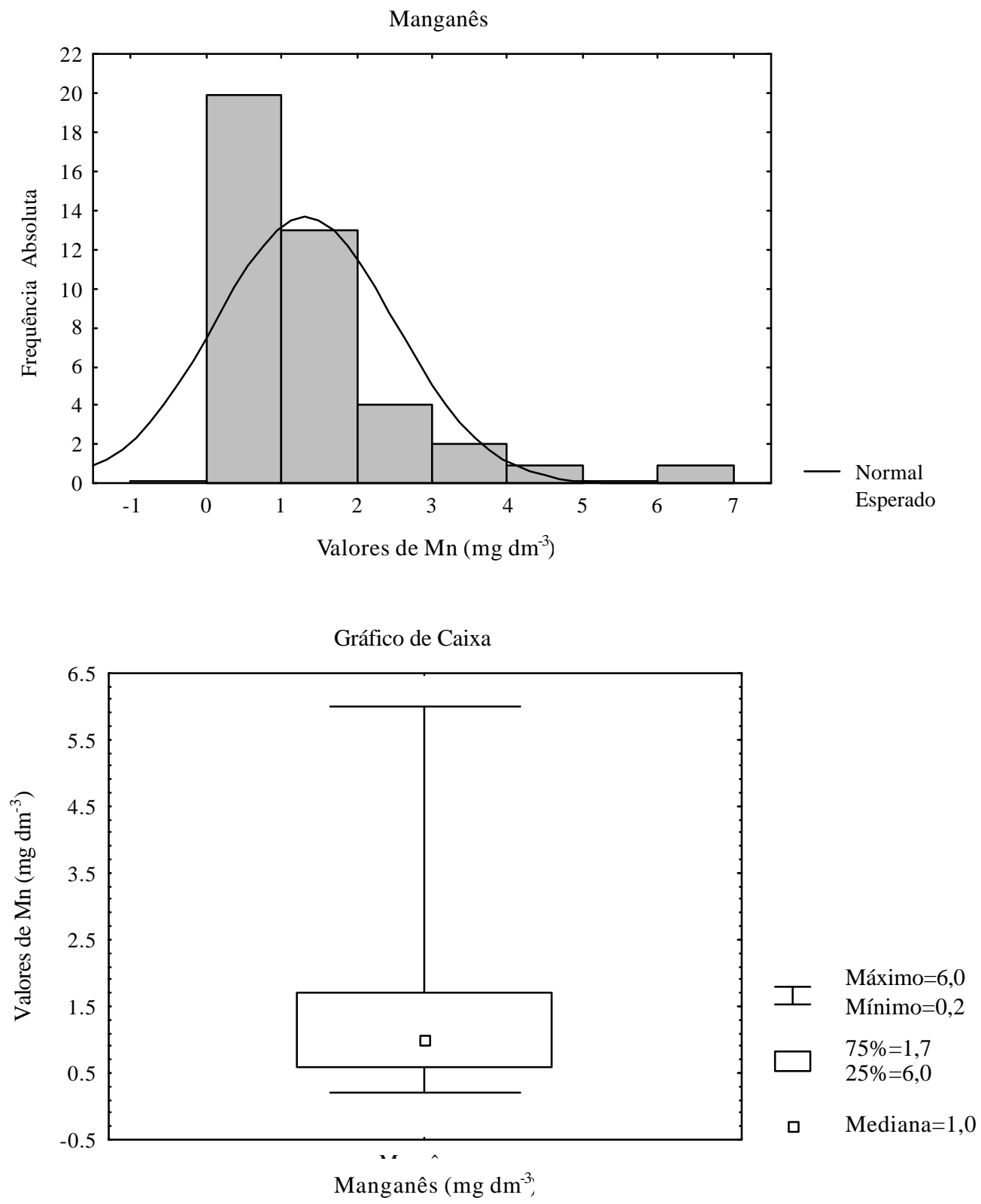

Figura 13 - Histograma de probabilidade normal e gráfico de caixa para Mn 
A variabilidade dos dados em torno da média foi classificada de acordo com os critérios propostos por Warrick \& Nielsen (1980), considerando os valores do coeficiente de variação $(\mathrm{CV})$. As variáveis $\mathrm{Cot}, \mathrm{IS}, \mathrm{pH}, \mathrm{m} \%$, ArgT apresentaram baixa variabilidade; MO, P, S, Mg, Al, H+Al, T, CTC, B, Fe, Zn, AreG, ArM, ArF, ArMF, AreT, Silt, ArgA, Floc, SilAr, Umi, apresentaram média variabilidade; e K, Ca, SB, V\%, Cu, Mn, ArMG, alta variabilidade. Os valores do $\mathrm{CV}$ obtidos para as variáveis $\mathrm{MO}, \mathrm{pH}, \mathrm{K}, \mathrm{H}+\mathrm{Al}, \mathrm{CTC}$, ArgT, AreT são semelhantes aos dos trabalhos de Marques Junior et al. (2000) e Pocay (2000).

Foi verificado que o valor mínimo de $\mathrm{pH}(3,30)$ foi menor que o valor do limite crítico inferior $(3,37)$, podendo existir valores influentes na distribuição, como demonstram as Figuras 14 e 15. O mesmo foi constatado para $\mathrm{P}$ e $\mathrm{m} \%$. Com respeito ao limite superior, verificourse que o valor máximo para MO (44) bi maior que o do limite superior (38), indicando a possível existência de valores influentes, como demonstram as Figuras 16 e 17. O mesmo foi constatado para P, Ca, Al, H+Al, SB, T, V\%, CTC, Cu, Mn, Zn, ArM, ArF, Silt, Umi e SilAr.

Em todas estas variáveis o intervalo que contém $50 \%$ dos dados (AI) apresenta uma variação considerada pequena se comparada com a dispersão total dos dados (AT), todas inferiores a 30\%, ou seja, a participação de $50 \%$ dos dados representou menos de um terço da dispersão total dos valores, evidenciando a grande suscetibilidade da amplitude total a valores extremos. As variações em termos de análise dos quartis são importantes, uma vez que não são influenciadas por valores extremos, possivelmente atípicos, podendo ser consideradas como medidas mais apropriadas para análise da dispersão dos dados.

Por exemplo, a variável P apresentou para o intervalo que contém 50\% dos dados (AI) valor igual a 1, uma variação considerada pequena quando comparada com a dispersão total dos dados (AT), de valor igual a 6, uma vez que corresponde a apenas $16,6 \%$ da dispersão total dos dados, indicando uma pequena concentração de dados próximos à média, evidenciando a grande suscetibilidade do conjunto de dados a valores extremos, como demonstram as Figuras 18 e 19. 
Gráfico de Probabilidade Normal

$\mathrm{pH}$
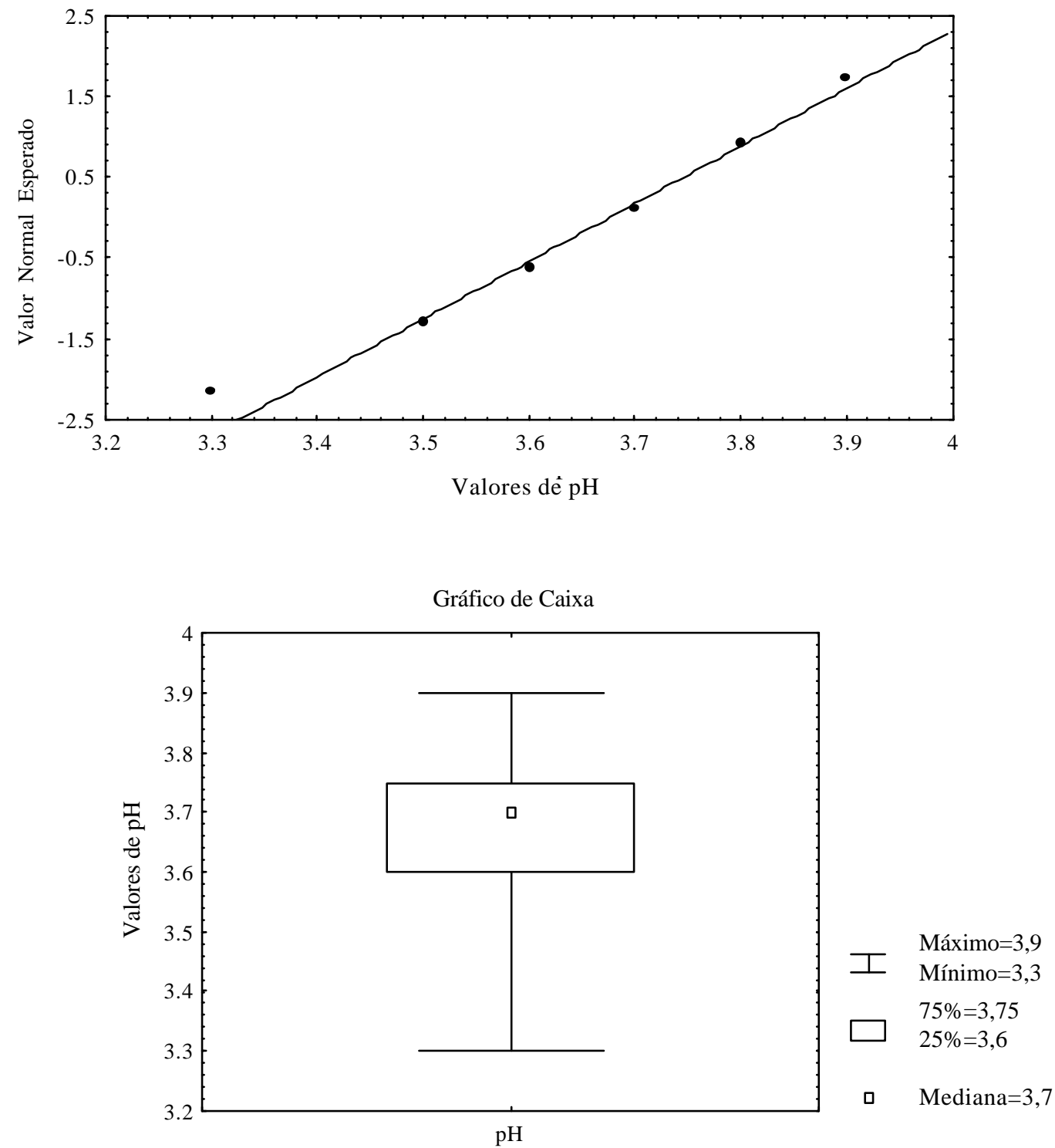

Figura 14 - Gráfico de probabilidade normal e de caixa para pH 


$\begin{array}{clc}\text { Ramos } & \text { Folhas } & \text { Unidade } \\ 39 & 000 & 3 \\ 38 & & \\ 38 & 00000000 & 8 \\ 37 & & \\ 37 & 000000000000000 & 15 \\ 36 & & \\ 36 & 00000000 & 8 \\ 35 & & 6 \\ 35 & 000000 & \\ 34 & & \\ 34 & & 1 \\ 33 & & \\ 33 & 0 & \end{array}$

Figura 15 - Gráfico de ramos e folhas para $\mathrm{pH}$

$\begin{array}{crc}\text { Ramos } & \text { Folhas } & \text { Unidade } \\ 44 & 0 & 1 \\ 42 & & \\ 40 & 0 & 1 \\ 38 & 00 & 2 \\ 36 & 000 & 3 \\ 34 & 00 & 2 \\ 32 & 000000 & 6 \\ 30 & 000000000 & 9 \\ 28 & 000000000000 & 12 \\ 26 & 00 & 2 \\ 24 & 00 & 2 \\ 22 & 0 & 1\end{array}$

Figura 16 - Gráfico de ramos e folhas para MO 
Gráfico de Probabilidade Normal

Matéria Orgânica

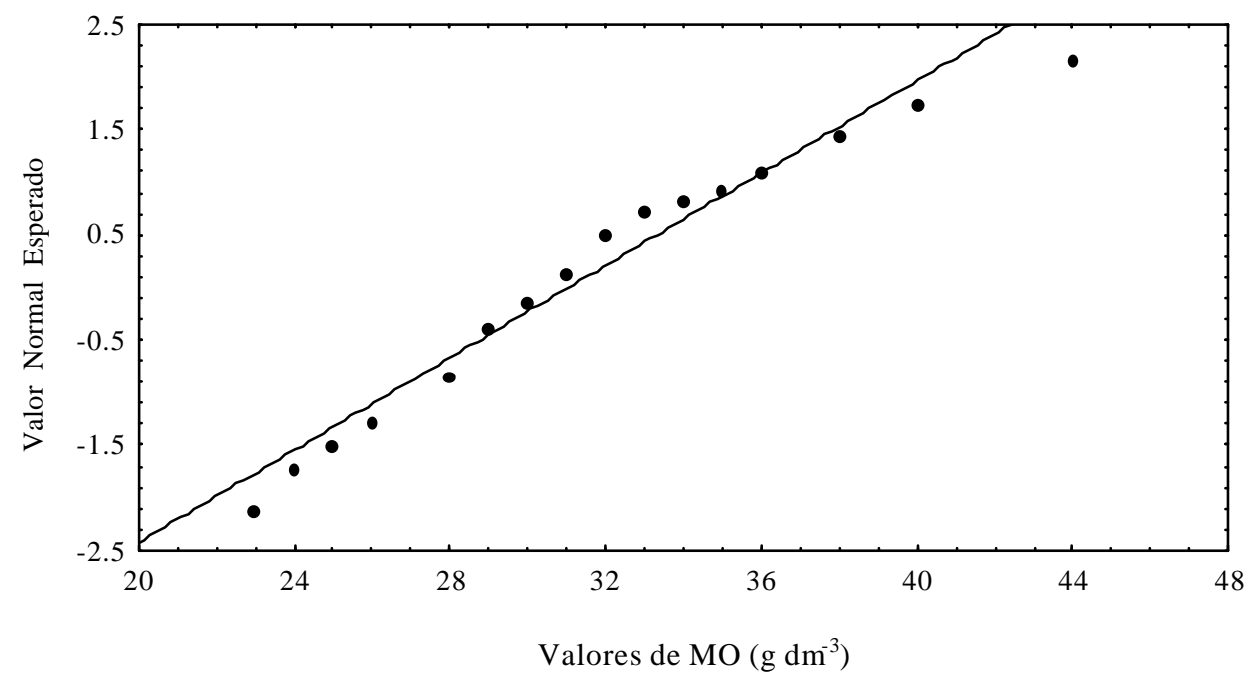

Gráfico de Caixa

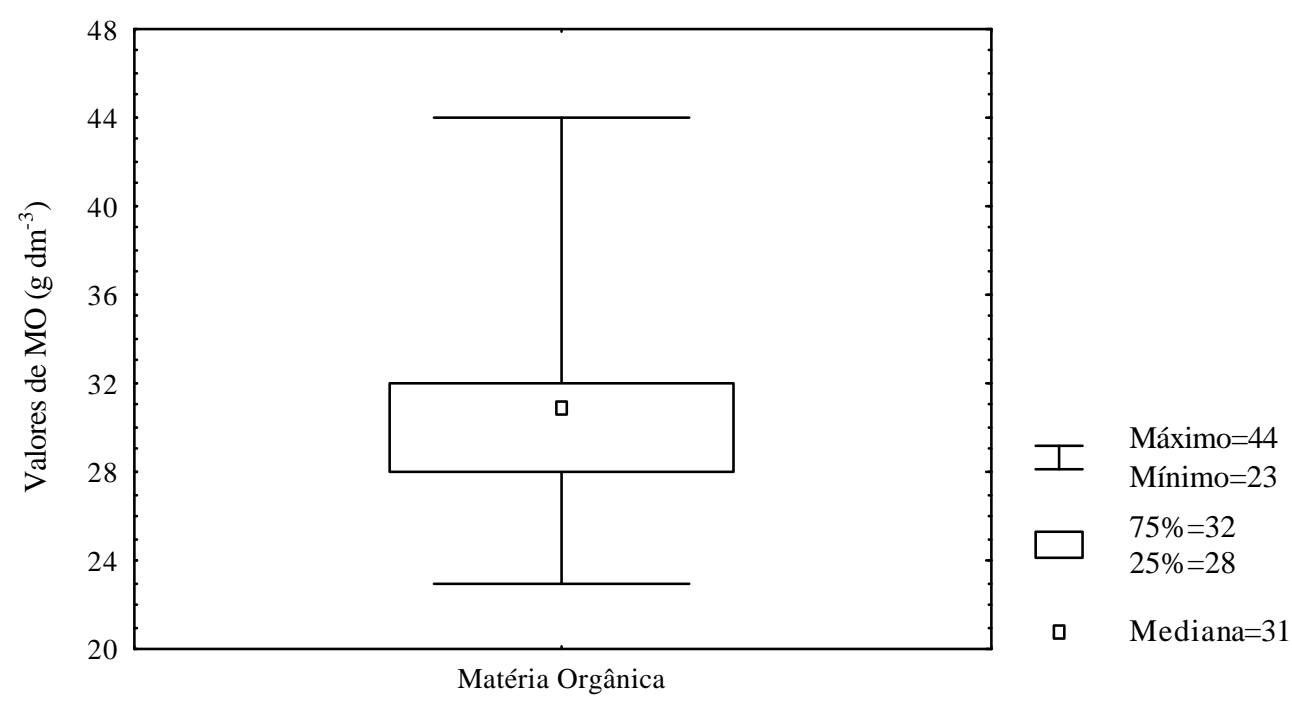

Figura 17 - Gráfico de probabilidade normal e de caixa para MO 

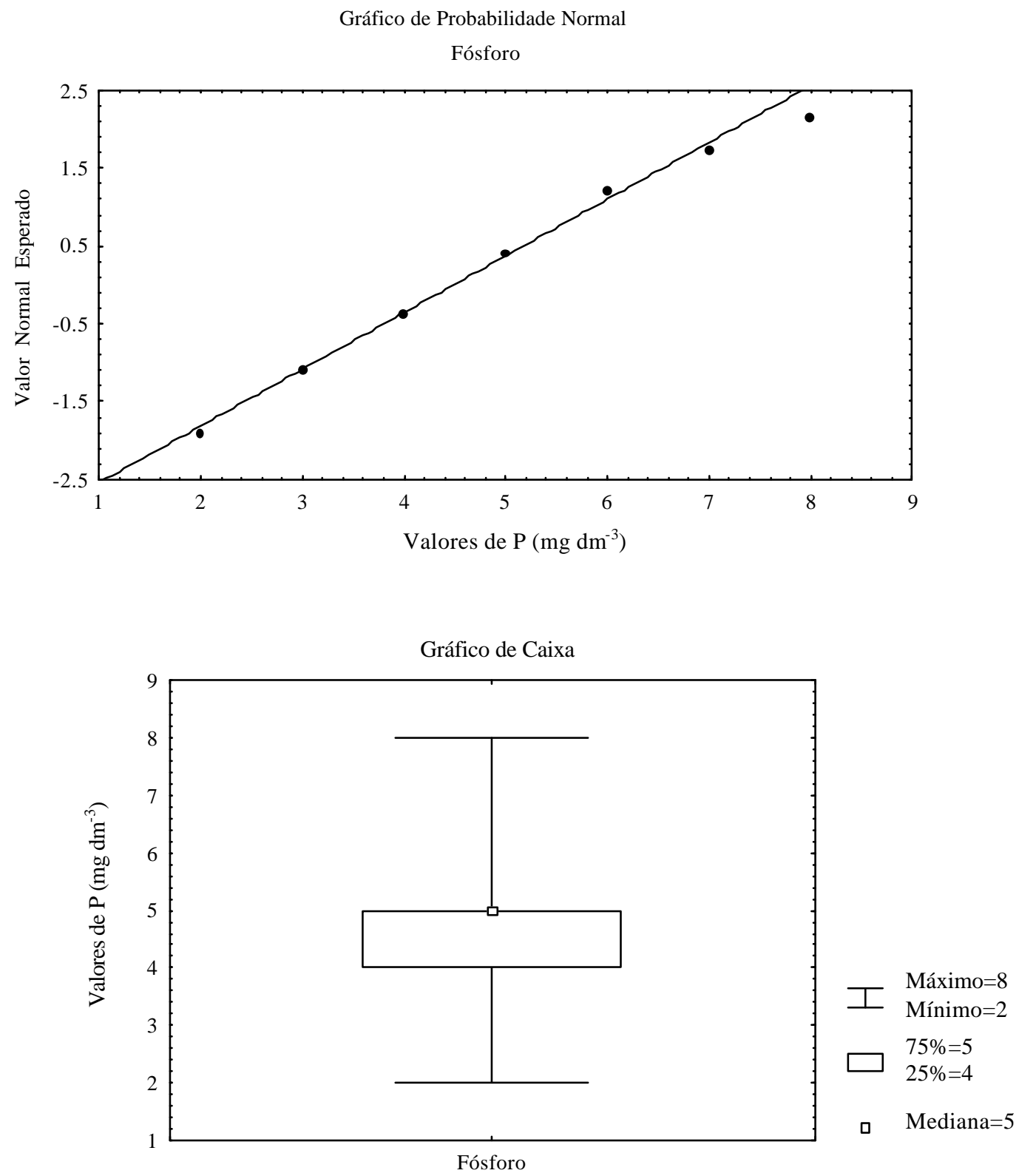

Figura 18 - Gráfico de probabilidade normal e de caixa para $\mathrm{P}$ 


$\begin{array}{crc}\text { Ramos } & \text { Folhas } & \text { Unidade } \\ 8 & 0 & 1 \\ 7 & & \\ 7 & 0 & 1 \\ 6 & 00000 & 5 \\ 6 & & \\ 5 & & 14 \\ 5 & 00000000000000 & 11 \\ 4 & & \\ 4 & 00000000000 & 7 \\ 3 & 0000000 & \\ 3 & & 2 \\ 2 & 00 & \end{array}$

Figura 19 - Gráfico de ramos e folhas para P

A decisão de excluir estes valores influentes foi tomada de acordo com Libardi et al. (1996), após confrontar os candidatos a valores influentes com seus vizinhos mais próximos nos gráficos de distribuição espacial ("postplot"), Figuras 20, 21 e 22. Nestes, as amostras são divididas em classes representadas por símbolos, possibilitando também identificar a existência de sub-regiões (símbolos com cores iguais de forma concentrada) e/ou tendências (variações graduais em alguma direção - x/y), situações, segundo Queiroz (1995) e Ribeiro Junior (1995), incompatíveis com a hipótese intrínseca assumida na análise geoestatística. 


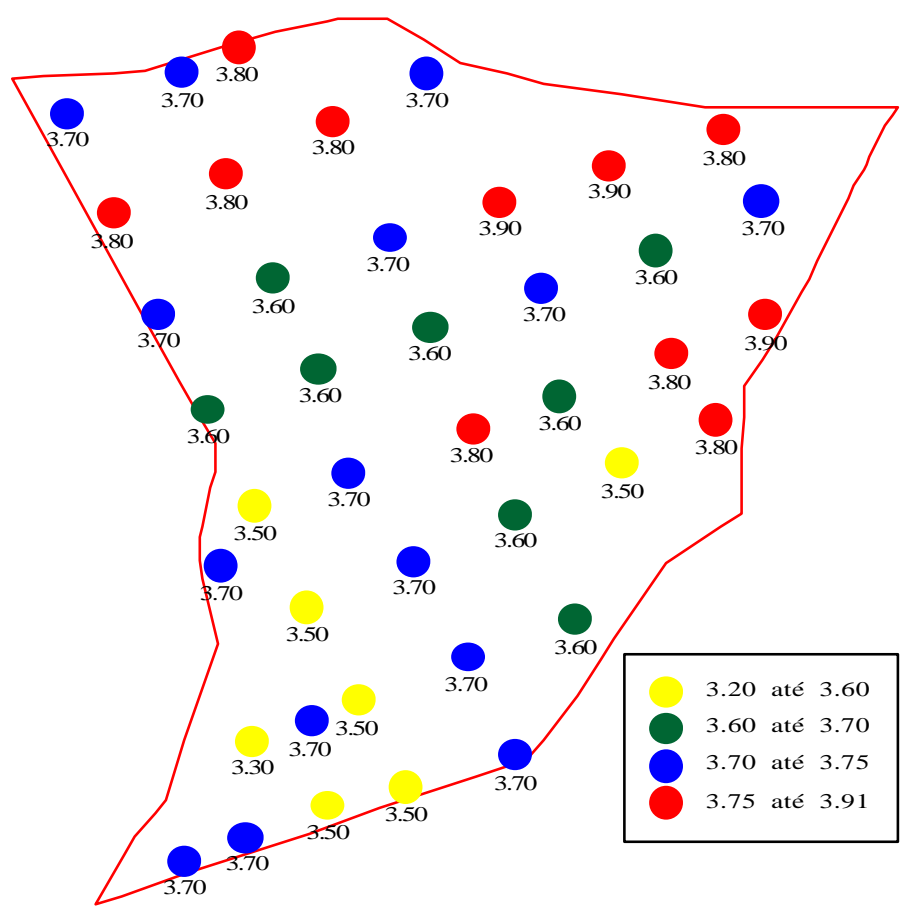

Figura 20 - Gráfico de distribuição espacial para pH

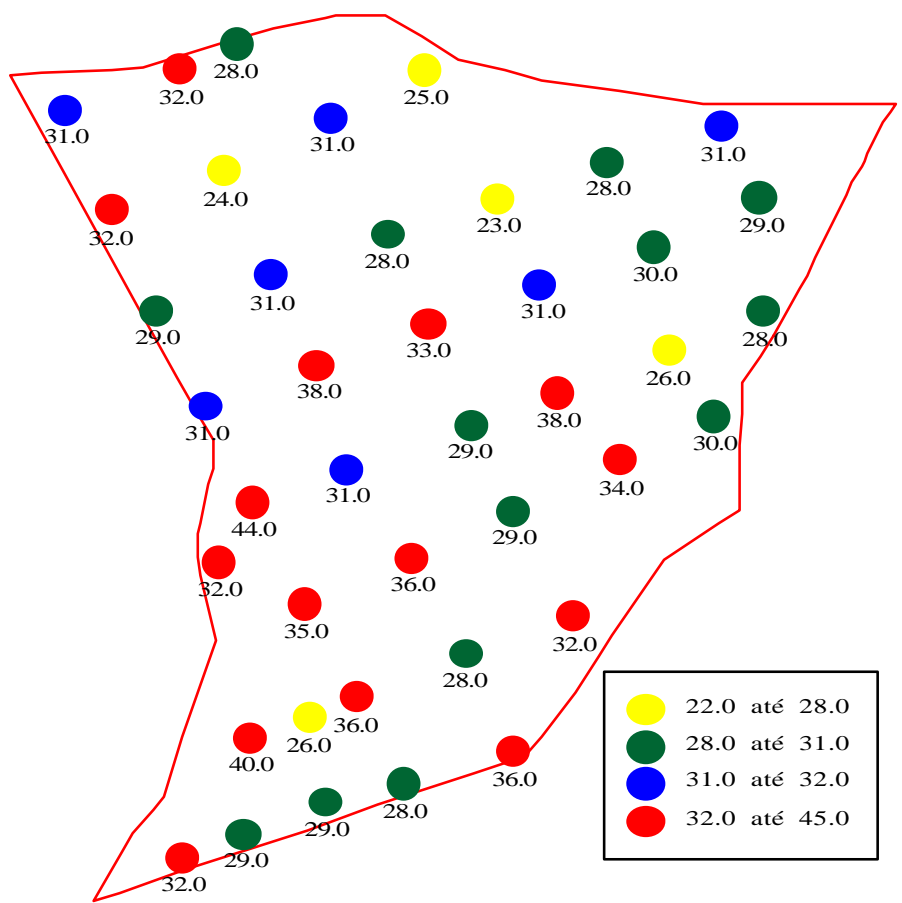

Figura 21 - Gráfico de distribuição espacial para MO 


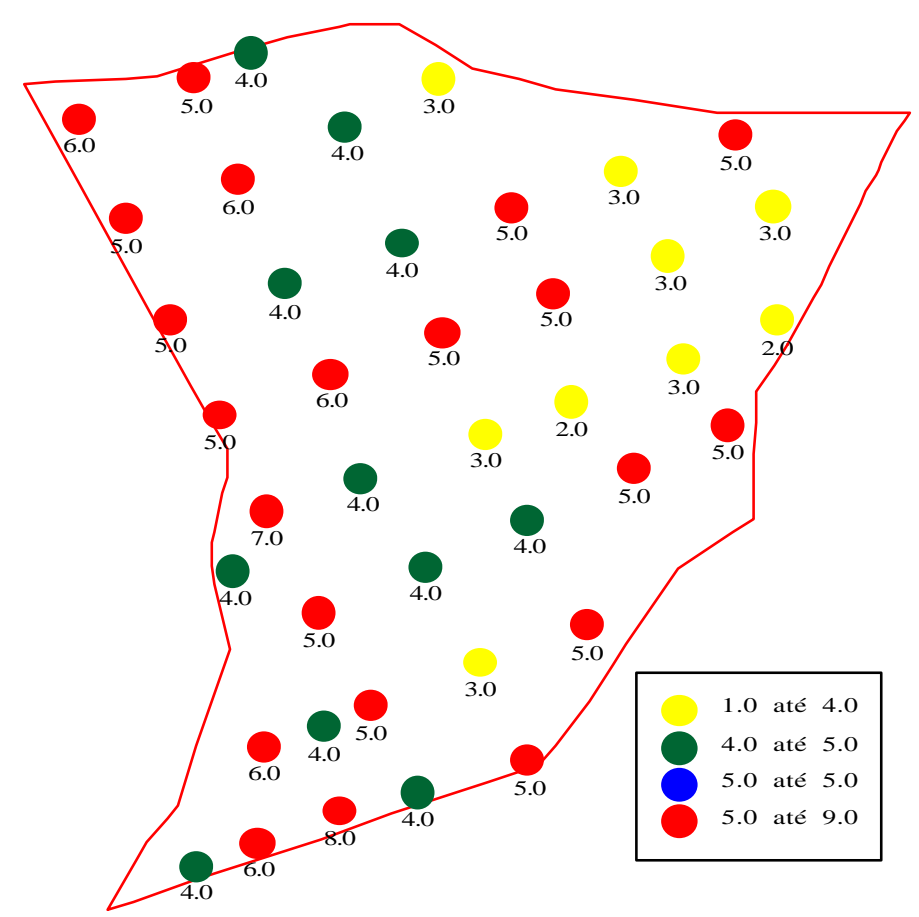

Figura 22 - Gráfico de distribuição espacial para $\mathrm{P}$

Os gráficos apresentados demonstram que os valores abaixo do LI são cercados por valores baixos, enquanto que os valores acima de LS são cercados por valores altos, o que somado ao fato de que estas observações não apresentam valores tão diferentes dos apresentados pela maioria das observações, leva a supor que não existam valores influentes e, conseqüentemente, aceitação da hipótese de não retirar estas observações do conjunto de dados. O mesmo foi constatado para Al, Cu, pH, Zn, ArM, ArF, Umi e Sil.

Naturalmente, em função da continuidade espacial do atributo, um certo nível de concentração tende sempre a ocorrer, como verificado na Figura 20, onde os valores mais baixos (amarelo) estão concentrados na parte de baixo e os mais altos (vermelho) na parte de cima do mapa. Na Figura 22 nota-se que os valores mais baixos (amarelo) estão concentrados àdireita do mapa.

O gráfico "postplot" para m\% (Figura 23) demonstra que o valor abaixo do LI não tem como vizinhos valores baixos, o que somado ao fato de que esta observação apresenta um valor significativamente diferente dos apresentados pela maioria das 
observações, leva a afirmar que se trata de um valor influente e, conseqüentemente, admitir a hipótese de eliminação desta observação do conjunto de dados. O mesmo foi constatado para Ca, H+Al, SB, T, V\%, CTC, Mn e SilArg.

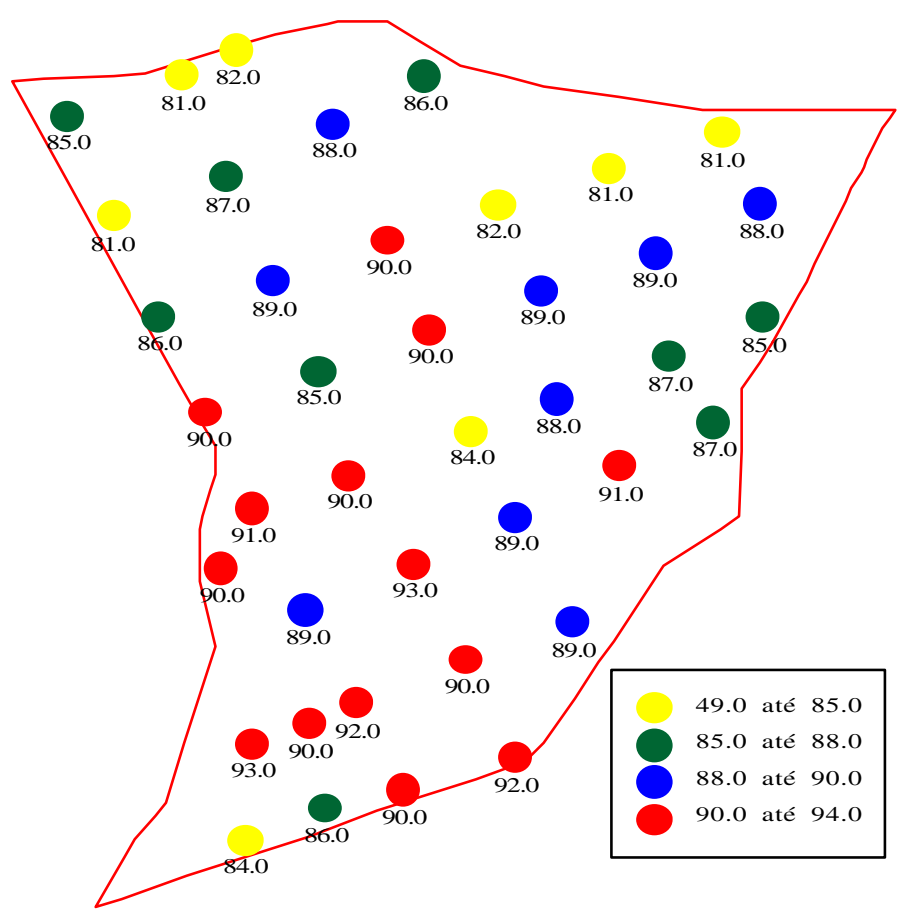

Figura 23 - Gráfico de distribuição espacial para m\%

Nos conjuntos de dados em que foi confirmada a presença de valores influentes, estes foram descartados e, para estas variáveis, aplicaram-se novamente os procedimentos da análise descritiva e exploratória sem os valores influentes (Tabela 13). Os resultados obtidos com este conjunto de dados foram comparados com os resultados anteriores.

Foi verificado, no geral, que a retirada dos valores influentes implicou em uma modificação significativa e positiva dos valores das medidas estatísticas e matemáticas. Como exemplo são apresentados o histograma de probabilidade normal e o gráfico de caixa de $\mathrm{m} \%$ sem o valor influente, Figura 24, que podem ser comparados com a Figura 
12; assim como o gráfico de probabilidade normal de V\% sem o valor influente (Figura 25) que pode ser comparado com o mesmo gráfico com o valor influente (Figura 10).

Em ambos é evidente a melhora nos valores das medidas de forma, como curtose e assimetria, assim como nas medidas de dispersão, variância, desvio-padrão e CV, demonstrando que a variabilidade dos dados em torno da média diminuiu, assegurando maior credibilidade à qualidade destas ferramentas como avaliadoras da variabilidade.

Os valores das medidas de posição também foram melhorados, visto que os valores da média e da mediana apresentados tornaram-se mais semelhantes. Segundo Costa Neto (1990), Libardi et al. (1996), Salviano (1996) e Farias (1999), valores destas três medidas aproximadamente iguais, sugerem um possível ajuste dos dados à distribuição normal.

O fato do conjunto de dados das variáveis não se ajustarem a uma distribuição normal implica na limitação da utilização de métodos oriundos da estatística clássica, para os quais esse requisito é básico (Mead \& Curnow, 1983). De acordo com Queiroz (1995), Farias (1999) e Eguchi (2001), se a distribuição não é normal, significa que a média aritmética é uma medida bastante influenciada pelos valores extremos, não sendo uma medida de tendência central adequada para a representação dos dados. Ao contrário, quando os dados se ajustam próximos à distribuição normal, a média aritmética pode ser considerada uma medida de tendência central representativa do conjunto de dados, podendo ser utilizada no sistema de manejo do solo (Carvalho, 1991; Fietz, 1998 e Silva Junior, 2001). 
Tabela 13. Resumo estatístico

\begin{tabular}{|c|c|c|c|c|c|c|c|c|c|c|c|c|c|c|c|c|c|}
\hline Var & Méd & Medn & Mín & Máx & LI & $\mathbf{L S}$ & QI & QS & Vari & AT & AI & $\mathrm{CV}$ & $\overline{\text { DP }}$ & $\overline{C S}$ & $\mathrm{CC}$ & $\mathbf{W}$ & $\mathbf{K S}$ \\
\hline${ }^{1} \mathrm{Ca}$ & 1,53 & 1 & 1 & 18 & 1 & 1 & 1 & 1 & 7,05 & 17 & 0 & 172 & 2,65 & 6,25 & 39,6 & 0,000 & $0,433 * *$ \\
\hline${ }^{1} \underline{\mathbf{C a}}$ & 1,12 & 1 & 1 & 2 & 1 & 1 & 1 & 1 & 0,11 & 1 & 0 & 29,7 & 0,33 & 2,35 & 3,74 & 0,000 & 0,520 \\
\hline${ }^{1} \overline{\mathrm{H}+\mathrm{Al}}$ & 117,6 & 109 & 80 & 205 & 42,5 & 190,5 & 98 & 135 & 744,4 & 125 & 37 & 23,1 & 27,2 & 0,97 & 0,97 & 0,001 & $0,209 * *$ \\
\hline${ }^{1} \underline{\mathbf{H}+\mathbf{A l}}$ & 115,4 & 109 & 80 & 166 & 42,5 & 190,5 & 98 & 135 & 562,8 & 86 & 37 & 20,5 & 23,7 & 0,46 & $-1,00$ & 0,001 & $0,206 * *$ \\
\hline${ }^{1} \mathrm{SB}$ & 3,27 & 2,7 & 2,1 & 20,4 & 0,7 & 4,7 & 2,2 & 3,2 & 8,09 & 18,3 & 1 & 86,9 & 2,84 & 5,71 & 34,9 & 0,000 & 0,340 \\
\hline${ }^{1} \underline{\mathbf{S B}}$ & 2,84 & 2,65 & 2,1 & 4,9 & 0,7 & 4,7 & 2,2 & 3,2 & 0,59 & 2,8 & 1 & 27,0 & 0,77 & 1,27 & 0,90 & 0,000 & $0,199 * *$ \\
\hline${ }_{1} \mathrm{~T}$ & 120,8 & 111,7 & 82,7 & 207,1 & 43,42 & 194,8 & 100,2 & 138,0 & 746,3 & 124 & 37,8 & 22,6 & 27,3 & 0,91 & 0,78 & 0,002 & $0,191 * *$ \\
\hline${ }^{1} \underline{\mathbf{T}}$ & 118,7 & 111,5 & 82,7 & 169,1 & 43,67 & 194,6 & 100,3 & 138,0 & 570,1 & 86,4 & 37,7 & 20,1 & 23,8 & 0,42 & $-1,11$ & 0,002 & $0,186^{* *} *$ \\
\hline${ }^{1} \mathrm{CTC}$ & 23,73 & 22,4 & 16,7 & 40,4 & 13,65 & 32,45 & 20,7 & 25,4 & 22,13 & 23,7 & 4,7 & 19,8 & 4,70 & 1,51 & 3,24 & 0,000 & $0,164^{* *}$ \\
\hline${ }^{1} \underline{\mathrm{CTC}}$ & 23,32 & 22,4 & 16,7 & 35,1 & 13,9 & 32,3 & 20,8 & 25,4 & 15,40 & 18,4 & 4,6 & 16,8 & 3,92 & 0,95 & 1,19 & 0,043 & $0,152 * *$ \\
\hline${ }^{2} \mathrm{~V}$ & 2,73 & 2 & 1 & 14 & 0,5 & 4,5 & 2 & 3 & 4,20 & 13 & 1 & 75,0 & 2,04 & 4,37 & 23,4 & 0,000 & 0,277 \\
\hline${ }^{2} \underline{\mathbf{V}}$ & 2,45 & 2 & 1 & 5 & 0,5 & 4,5 & 2 & 3 & 0,971 & 4 & 1 & 40,2 & 0,98 & 0,99 & 0,77 & 0,000 & 0,325 \\
\hline${ }^{2} \bar{m}$ & 86,58 & 88 & 50 & 93 & 77,5 & 97,5 & 85 & 90 & 46,04 & 43 & 5 & 7,83 & 6,78 & $-4,07$ & 21,4 & 0,000 & $0,188^{* *}$ \\
\hline${ }^{2} \underline{\mathbf{m}}$ & 87,5 & 88,5 & 81 & 93 & 77,5 & 97,5 & 85 & 90 & 12,0 & 12 & 5 & 3,96 & 3,47 & $-0,53$ & $-0,63$ & 0,008 & $0,167 * *$ \\
\hline${ }^{3} \overline{\mathrm{Mn}}$ & 1,31 & 1 & 0,2 & 6 & 0 & 3,35 & 0,6 & 1,7 & 1,43 & 5,8 & 1,1 & 91,3 & 1,19 & 2,15 & 5,55 & 0,000 & $0,195^{* *}$ \\
\hline${ }^{3} \underline{M n}$ & 1,19 & 0,9 & 0,2 & 4,4 & 0 & 3,35 & 0,6 & 1,7 & 0,89 & 4,2 & 1,1 & 72,1 & 0,94 & 1,61 & 2,80 & 0,000 & $0,172 * *$ \\
\hline$\overline{\mathrm{SilAr}}$ & 0,15 & 0,15 & 0,03 & 0,34 & 0 & 0,32 & 0,10 & 0,19 & 0,004 & 0,30 & 0,09 & 41,7 & 0,06 & 0,57 & 0,49 & $0,487^{*}$ & $0,085^{* *}$ \\
\hline$\underline{\text { SilAr }}$ & 0,14 & 0,14 & 0,03 & 0,27 & 0 & 0,32 & 0,10 & 0,19 & 0,003 & 0,23 & 0,09 & 38,5 & 0,05 & 0,15 & $-0,58$ & $0,623^{*}$ & $0,088^{* *}$ \\
\hline
\end{tabular}

Conjunto completo e sem valores influentes.

* significativo ao nível de $5 \%$ de probabilidade $(\mathrm{P} \geq 0,05)$.

** significativo pelo teste de Kolmogorov-Smirnov.

Unidades: ${ }^{1}$ (mmolc dm $\left.{ }^{-3}\right) ;{ }^{2}(\%) ;{ }^{3}\left(\mathrm{mg} \mathrm{dm}^{-3}\right)$. 

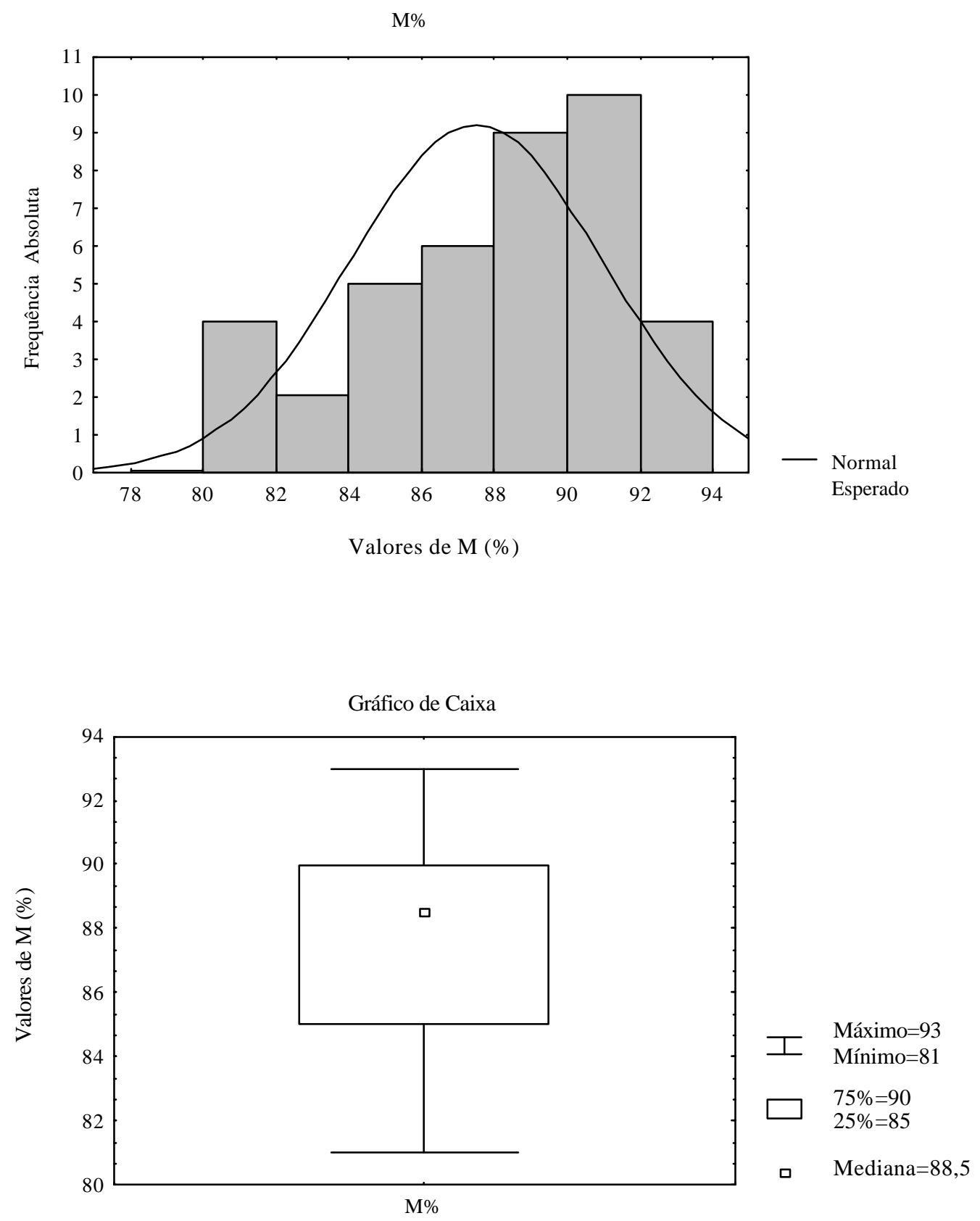

Figura 24 - Histograma de probabilidade normal e gráfico de caixa para m\% sem o valor influente 


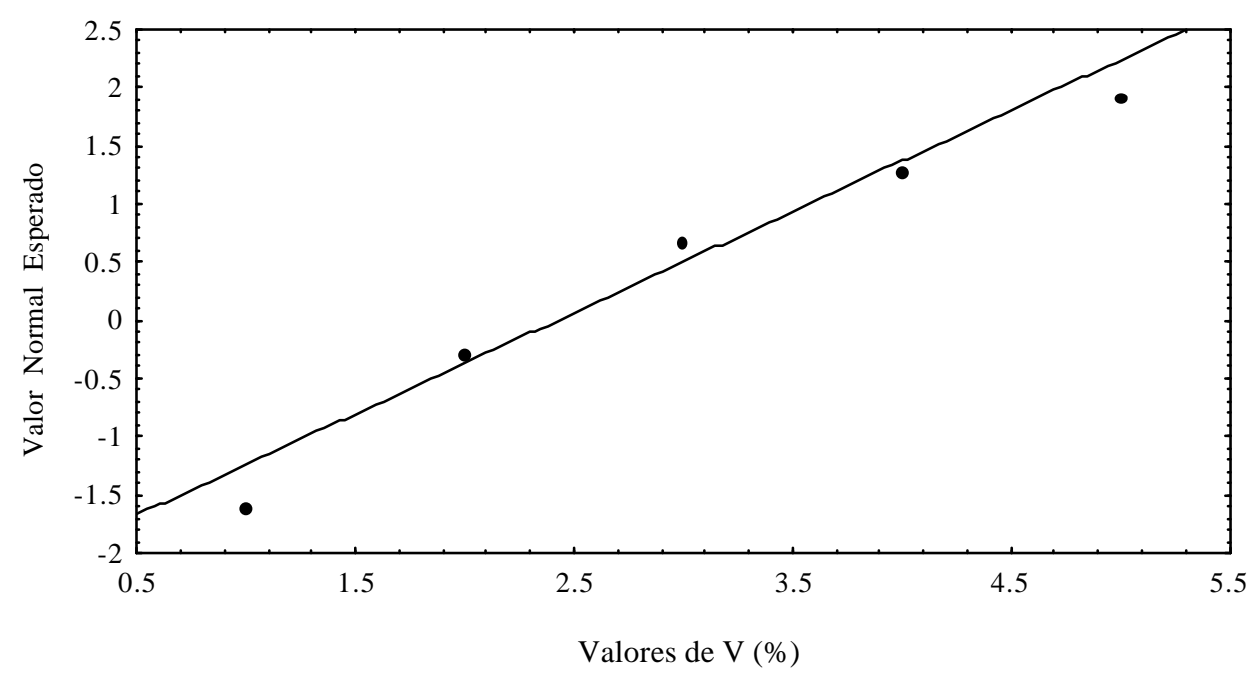

Figura 25 - Gráfico de probabilidade normal para V\% sem o valor influente

Como os valores de d (KS) para Ca e V\% (Tabela 13) estão além de 0,252, considera-se que a distribuição destas variáveis não é normal. Sendo assim, foi testada a possível distribuição log normal destas variáveis, o que também não foi confirmada.

\subsubsection{Semivariogramas experimentais}

Na Tabela 14 são apresentados os valores dos parâmetros dos semivariogramas, escalonados (divididos) pela variância, ajustados para cada uma das variáveis estudadas. O escalonamento possibilita comparações entre os valores obtidos para os diferentes parâmetros, permitindo verificar se as variáveis contam com o mesmo padrão de variabilidade espacial, ou seja, valores de efeito pepita, alcance, patamar, etc. semelhantes ou não, uma vez que assumem valores em uma escala padronizada. 
Tabela 14. Parâmetros dos semivariogramas ajustados para as variáveis estudadas

\begin{tabular}{|c|c|c|c|c|c|c|c|}
\hline Variáve & Modelo & $\mathbf{C}_{0}$ & $\left(C_{0}+C\right)$ & $\mathbf{a ( m )}$ & $\mathrm{C}_{0} /\left(\mathrm{C}_{0}+\mathrm{C}\right) .100$ & $\mathbf{r}^{2}(\%)$ & RSS \\
\hline AreG & Gaussiano & 0,722 & 1,468 & 255,3 & 49,1 & 84,7 & 0,039 \\
\hline ArMF & Gaussiano & 0,455 & 1,248 & 204,4 & 36,4 & 93,7 & 0,027 \\
\hline AreT & Gaussiano & 0,533 & 1,394 & 261,1 & 38,2 & 79,3 & 0,190 \\
\hline $\operatorname{ArgA}$ & Esférico & 0,321 & 1,106 & 125,1 & 29,0 & 83,1 & 0,067 \\
\hline $\operatorname{Arg} \mathrm{T}$ & Gaussiano & 0,408 & 1,346 & 219,7 & 30,3 & 95,2 & 0,042 \\
\hline Cotas & Esférico & 0,001 & 1,734 & 326,3 & 0,05 & 98,0 & 0,093 \\
\hline IS & Esférico & 0,001 & 1,139 & 84,9 & 0,08 & 99,0 & 0,000 \\
\hline $\mathrm{Cu}$ & Esférico & 0,001 & 1,133 & 251,9 & 0,08 & 90,8 & 0,323 \\
\hline SilArg & Esférico & 0,509 & 1,137 & 94,7 & 44,7 & 56,7 & 0,057 \\
\hline Sil & Esférico & 0,484 & 1,033 & 90,0 & 46,8 & 80,6 & 0,011 \\
\hline $\mathrm{Zn}$ & Gaussiano & 0,531 & 1,676 & 395,2 & 31,6 & 96,7 & 0,026 \\
\hline $\mathrm{pH}$ & Gaussiano & 0,671 & 1,647 & 380,0 & 40,7 & 89,0 & 0,095 \\
\hline $\mathrm{P}$ & Gaussiano & 0,809 & 1,121 & 270,0 & 72,1 & 83,0 & 0,012 \\
\hline $\mathrm{K}$ & Gaussiano & 0,609 & 1,219 & 270,4 & 49,9 & 98,3 & 0,003 \\
\hline $\mathrm{Mg}$ & Linear & 0,492 & 1,463 & 307,1 & 33,6 & 74,6 & 0,588 \\
\hline $\mathrm{Fe}$ & Exponencial & 0,001 & 0,978 & 142,2 & 0,10 & 78,1 & 0,233 \\
\hline Floc & Gaussiano & 0,487 & 1,272 & 155,2 & 38,2 & 100,0 & 0,000 \\
\hline$S$ & Esférico & 0,691 & 1,383 & 369,0 & 49,9 & 87,6 & 0,024 \\
\hline $\mathrm{Mn}$ & Exponencial & 0,124 & 2,258 & 296,8 & 5,49 & 97,9 & 0,023 \\
\hline $\mathrm{ArF}$ & Gaussiano & 0,522 & 1,251 & 238,9 & 41,7 & 93,4 & 0,025 \\
\hline ArMG & Gaussiano & 0,378 & 1,493 & 299,4 & 25,3 & 83,3 & 0,434 \\
\hline CTC & Esférico & 0,607 & 1,215 & 232,8 & 49,9 & 92,6 & 0,014 \\
\hline B & ----- & ----- & ----- & ----- & ----- & ----- & ----- \\
\hline $\mathrm{Ca}$ & Exponencial & 0,637 & 1,603 & 328,6 & 39,7 & 75,4 & 0,061 \\
\hline $\mathrm{Al}$ & Esférico & 0,543 & 1,165 & 214,2 & 46,6 & 89,2 & 0,023 \\
\hline SB & Esférico & 0,572 & 1,128 & 380,0 & 50,7 & 99,2 & 0,007 \\
\hline $\mathrm{m}$ & Esférico & 0,406 & 1,102 & 327,3 & 36,8 & 91,8 & 0,023 \\
\hline V & Esférico & 0,466 & 1,063 & 385,2 & 43,8 & 85,8 & 0,025 \\
\hline $\mathrm{T}$ & Esférico & 0,600 & 1,201 & 267,4 & 49,9 & 95,5 & 0,008 \\
\hline $\mathrm{H}+\mathrm{Al}$ & Exponencial & 0,373 & 1,200 & 244,2 & 31,0 & 91,4 & 0,021 \\
\hline $\mathrm{MO}$ & ---- & ---- & ----- & ----- & ----- & ---- & ---- \\
\hline ArM & Exponencial & 0,370 & 1,479 & 370,0 & 25,0 & 60,9 & 6,137 \\
\hline Umi & Linear & 0,120 & 1,515 & 266,0 & 7,9 & 94,9 & 0,116 \\
\hline
\end{tabular}


$\mathrm{C}_{\mathrm{o}}$ é o efeito pepita; $\left(\mathrm{C}_{\mathrm{o}}+\mathrm{C}\right)$ o patamar; $(\mathrm{m})$ o alcance em metros; $\mathrm{r}^{2}$ é o coeficiente de determinação, que expressa o ajuste do modelo de semivariograma aos dados; RSS é a Soma Reduzida dos Quadrados, uma medida que também expressa o ajuste do modelo aos dados, sendo mais sensível e robusta que o $r^{2}$. Quanto mais alto o $r^{2}$ e mais baixo a RSS melhor o ajuste do modelo de semivariograma aos dados.

Verificoutse que apenas B e MO apresentaram semivariogramas sem estrutura espacial, permitindo concluir que, nessa escala, as observações desses atributos não apresentaram correlação espacial, distribuindo-se de forma independente no espaço, não podendo ser expressas em função da distância de separação entre elas.

Para as demais variáveis estudadas, 31 ao todo, foi encontrada correlação ou dependência espacial entre as observações, permitindo ajustar quatro tipos de função teórica aos modelos de semivariograma, sendo 13 ao esférico, 11 ao gaussiano, 5 ao exponencial e 2 ao linear, concordando com Trangmar et al. (1987), Souza (1992), Cambardella et al. (1994), Albulquerque et al. (1996), Paz et al. (1996), Salviano (1996), Salviano et al. (1998), Jakob et al. (1999), Marques Junior et al. (2000), Baio (2001), Stendahl (2001) e Leal (2002), todos relatando que o modelo esférico apresentou o melhor ajuste para os semivariogramas ajustados, em seus respectivos trabalhos.

Outro parâmetro analisado dos semivariogramas foi o alcance da dependência espacial, que permite determinar a distância limite entre dependência e independência entre as amostras. Três variáveis (IS, Silt/Arg e Sil) apresentaram alcance no intervalo entre 0-100m. Stendahl (2001) encontrou alcance de dependência espacial entre $0120 \mathrm{~m}$ para vários atributos, como altura, diâmetro e área basal, em florestas de pinheiros na Suécia. Também três variáveis (ArgA, Floc, Fe e S) no intervalo 100-200m; quinze no intervalo 200-300m; e dez com alcance 300-405m, demonstrando que, no geral, os atributos estudados se apresentaram espacialmente dependentes a grandes distâncias, o que também foi constatado por Pocay (2000).

Com o valor do efeito pepita (Co) pode-se analisar o grau de dependência espacial das variáveis, utilizando a classificação de Cambardella et al. (1994). Seis semivariogramas apresentaram um nível forte de dependência espacial, sendo que o restante, 25, apresentou um nível moderado de dependência espacial. Exemplificando, 
isto quer dizer que para a variável IS o efeito pepita corresponde a $0,08 \%$ do patamar, ou seja, 99,92 da variabilidade foi explicada pela correlação espacial.

Segundo Trangmar et al. (1985), um efeito pepita de 0\% indica que o erro experimental é praticamente nulo e que não existe variação significativa a distâncias menores que a amostrada. Quanto menor a proporção do efeito pepita para o patamar, maior será a semelhança entre os valores vizinhos e a continuidade do fenômeno e menor a variância da estimativa e, portanto, maior a confiança que se pode ter nas estimativas (Vieira, 1997 e 1998).

Para as 2 variáveis que apresentaram semivariogramas sem estrutura espacial, afirma-se que ocorreu um efeito pepita puro, indicando que não houve dependência espacial entre os valores medidos, ou seja, as observações estão distribuídas ao acaso, visto que o alcance é inferior ao intervalo de amostragem.

Apenas para duas variáveis não foi obtido um valor de $r^{2}$ considerado alto, SilArg $(56,7 \%)$ e $\operatorname{ArM~(60,9\% ).~Todas~as~demais~apresentaram~valores~superiores~a~} 70 \%$, considerados altos, o que expressa o bom ajuste do modelo de semivariograma aos dados, que é confirmado pelos baixos valores obtidos para RSS, inclusive para a variável SilArg $(0,057)$. A variável ArM foi a única a apresentar um valor de RSS elevado $(6,13)$ se comparado aos obtidos para as demais.

Importante considerar que Shiratsuchi (2001), estudando a variabilidade espacial de infestações por plantas daninhas utilizando o programa GS+, validou o semivariograma ajustado para um banco de sementes de Alternanthera tenella, que apresentou $\mathrm{r}^{2}=55 \%$. No trabalho de Baio (2001), também utilizando o programa GS+ no estudo da variabilidade espacial de plantas daninhas, foram validados os semivariogramas ajustados para Leiteiro, Macelinha e Capim Carrapicho, que apresentaram $\mathrm{r}^{2}=30 \%, 35 \%$ e $46 \%$ respectivamente, assim como, os ajustados para V\%, $\mathrm{Zn}, \mathrm{Ca}$ e $\mathrm{pH}$, que apresentaram $\mathrm{r}^{2}=25 \%, 28 \%, 30 \%$ e $30 \%$, respectivamente.

Nas Figuras 26 a 36 são apresentados os semivariogramas escalonados pela variância, o que permite comparar visualmente o padrão de variabilidade espacial das diferentes variáveis. 


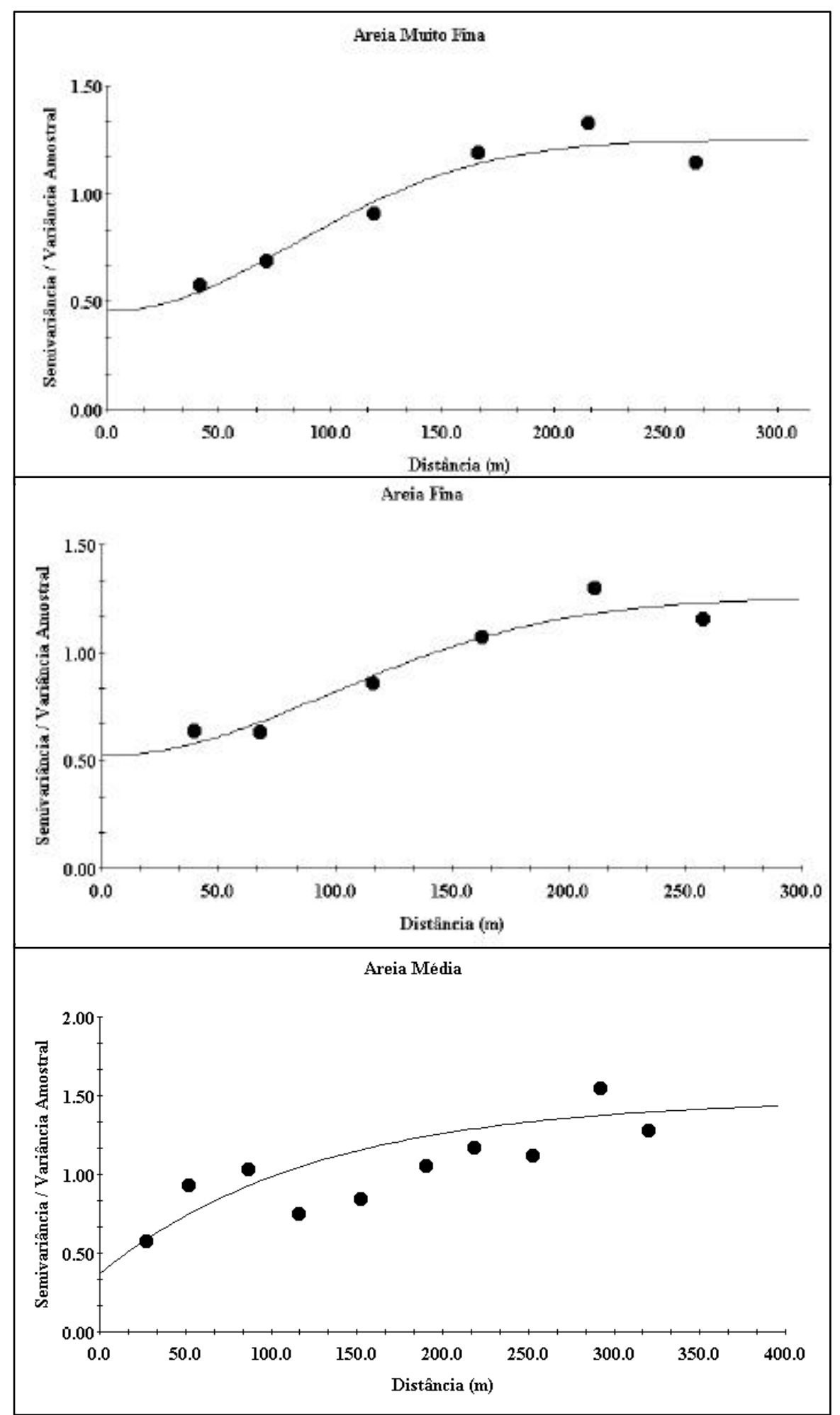

Figura 26 - Semivariogramas escalonados de ArMF, ArF e ArM 


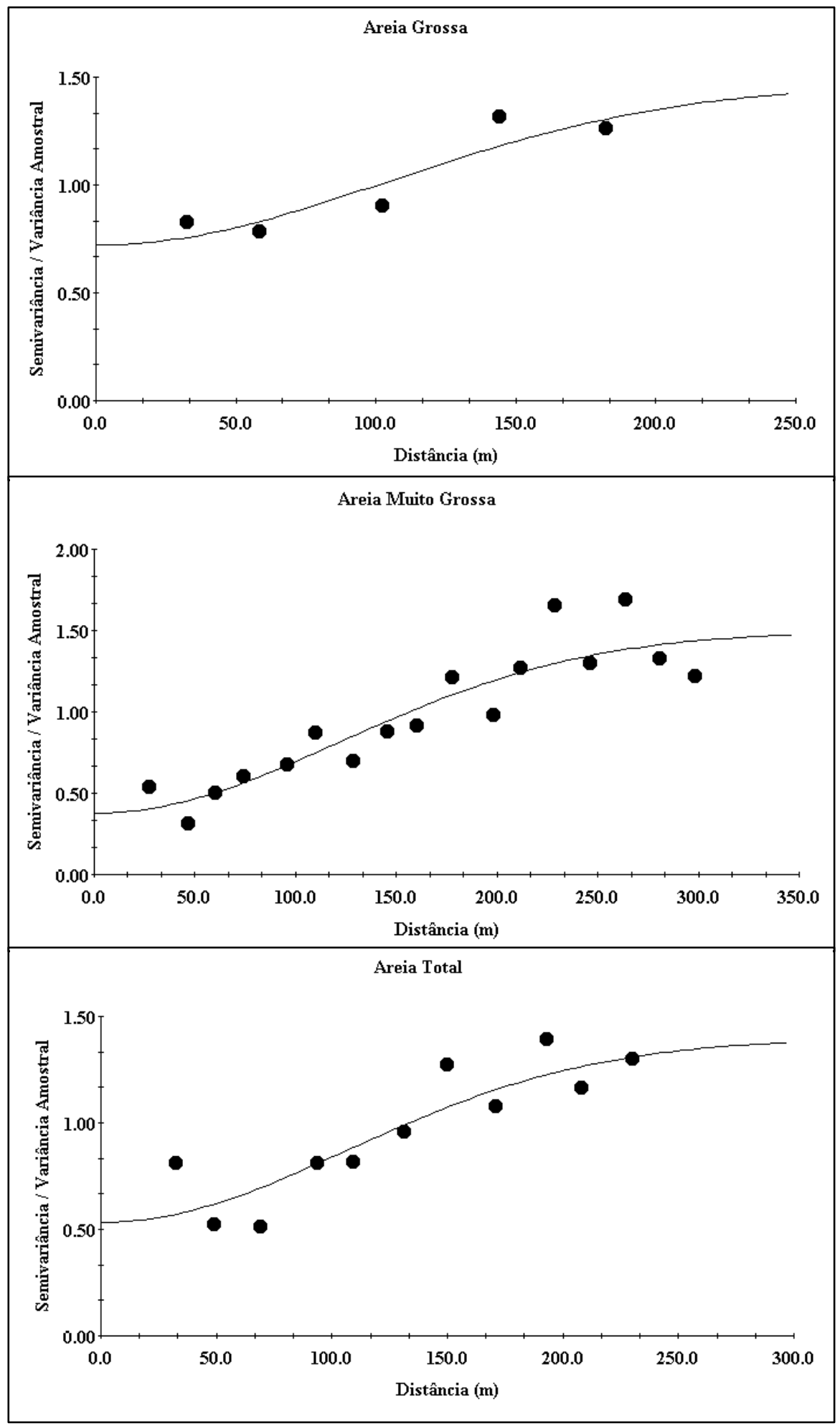

Figura 27 - Semivariogramas escalonados de AreG, ArMG e AreT 


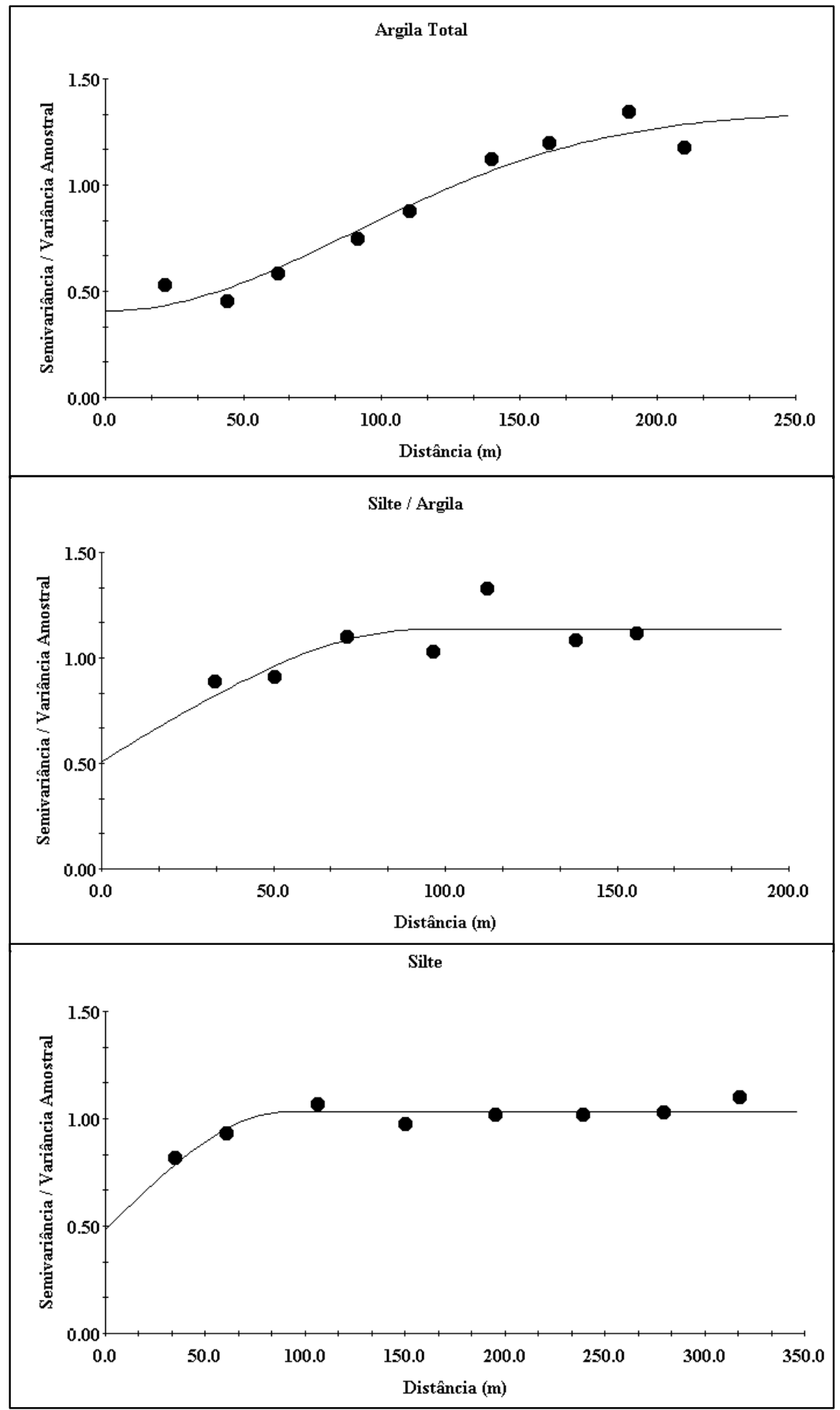

Figura 28 - Semivariogramas escalonados de ArgT, SilArg e Silte 


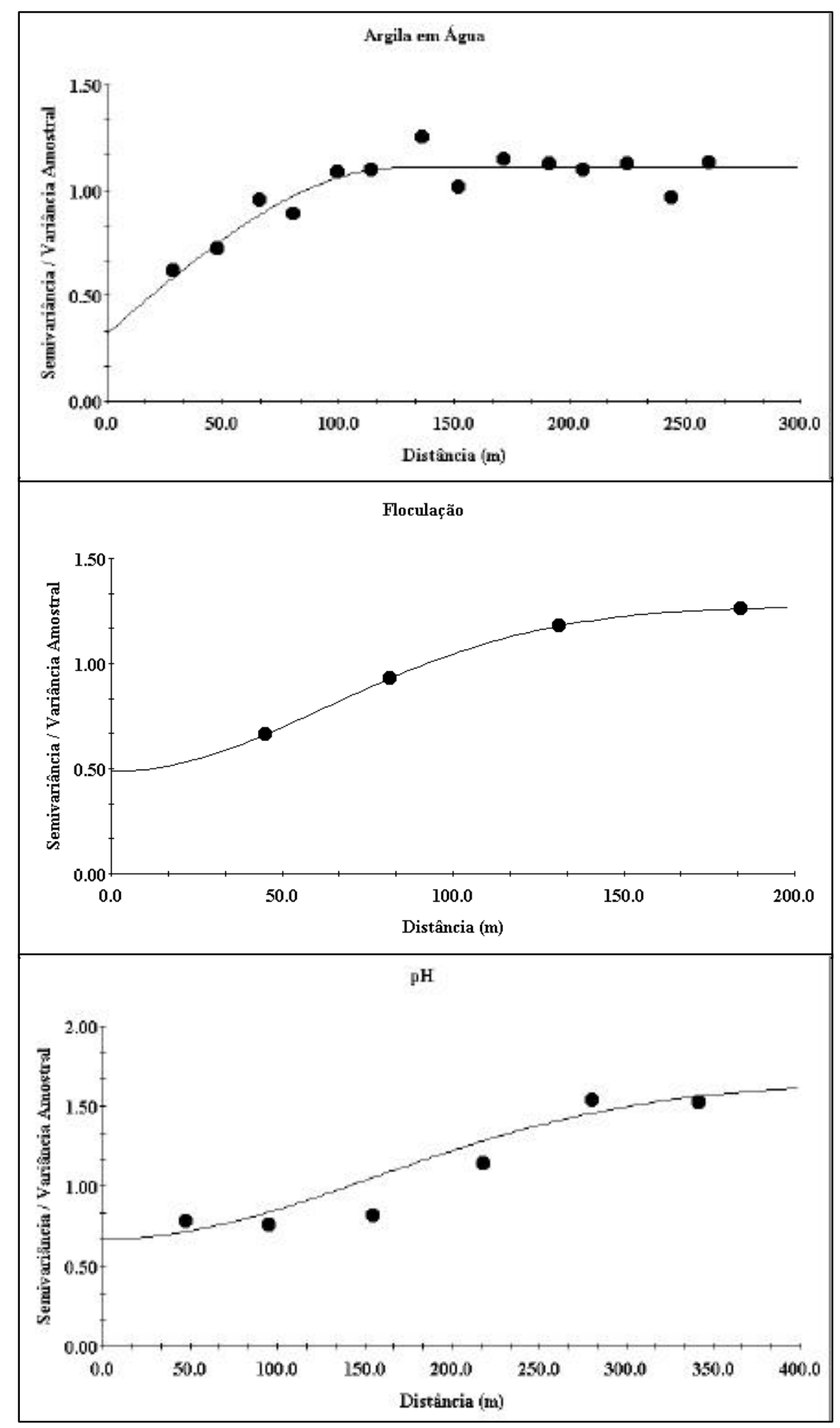

Figura 29 - Semivariogramas escalonados de ArgA, Floc e pH 


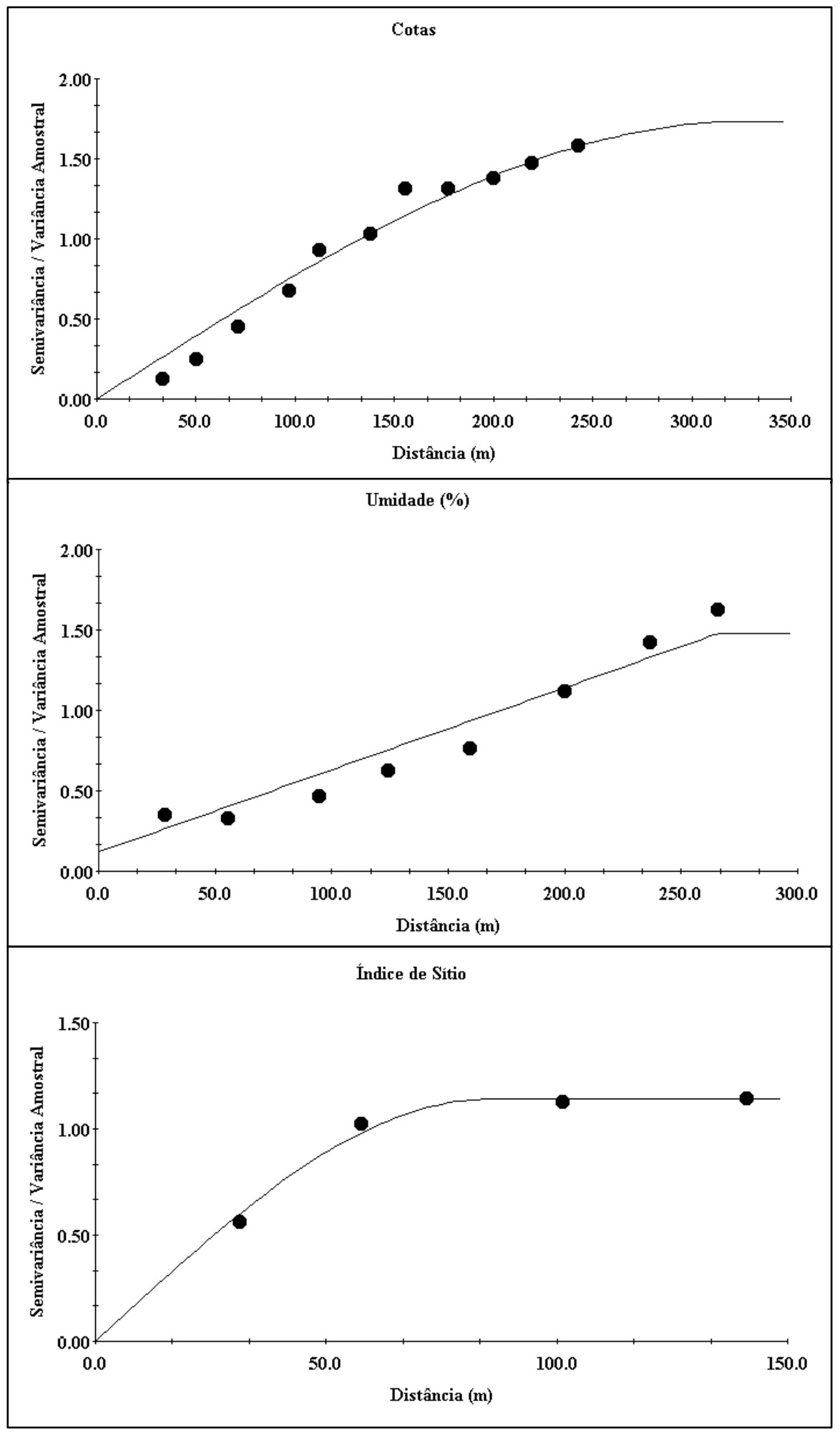

Figura 30 - Semivariogramas escalonados de Cotas, Umidade e IS 


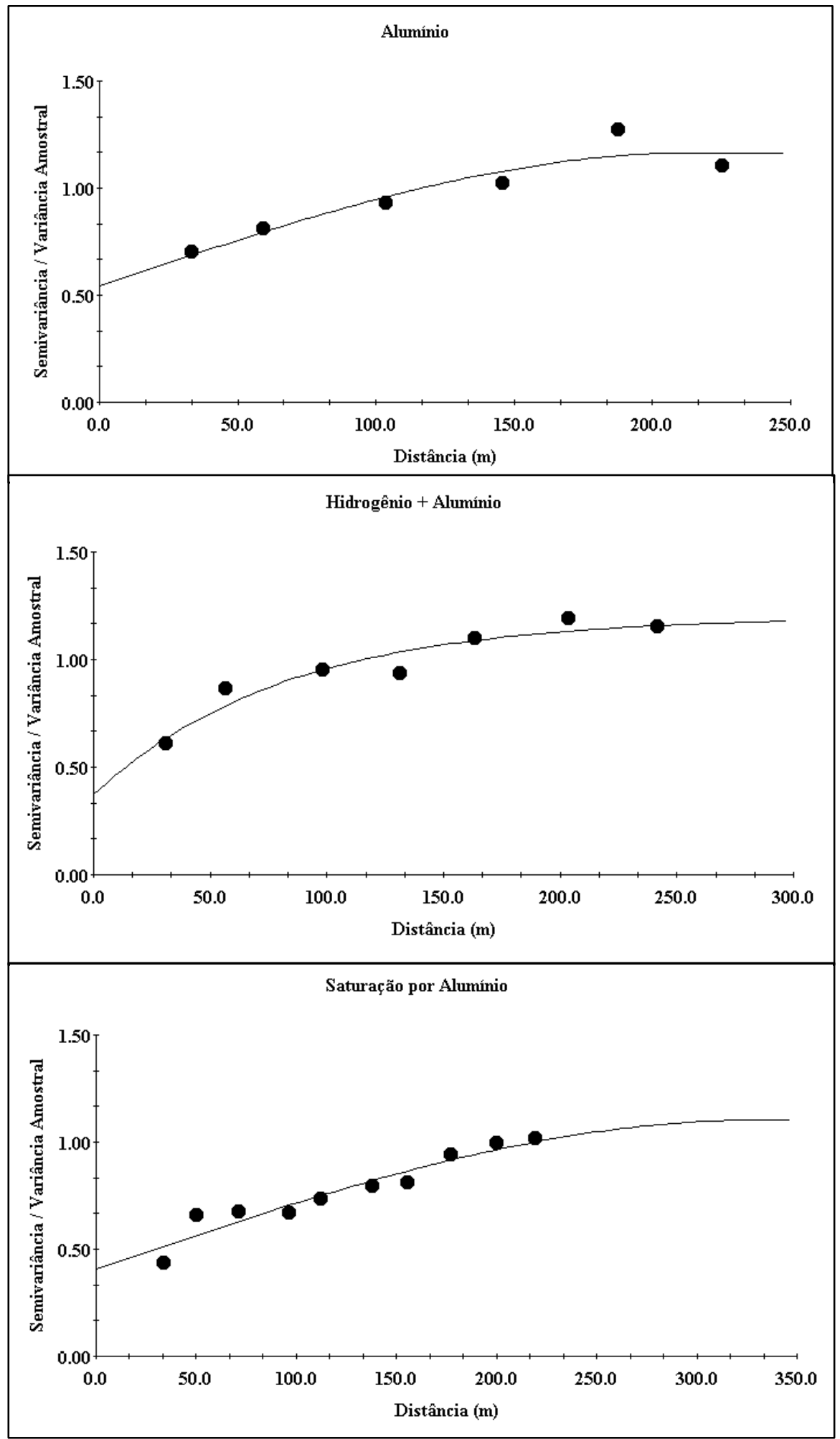

Figura 31 - Semivariogramas escalonados de Al, $\mathrm{H}+\mathrm{Al}$ e m\% 


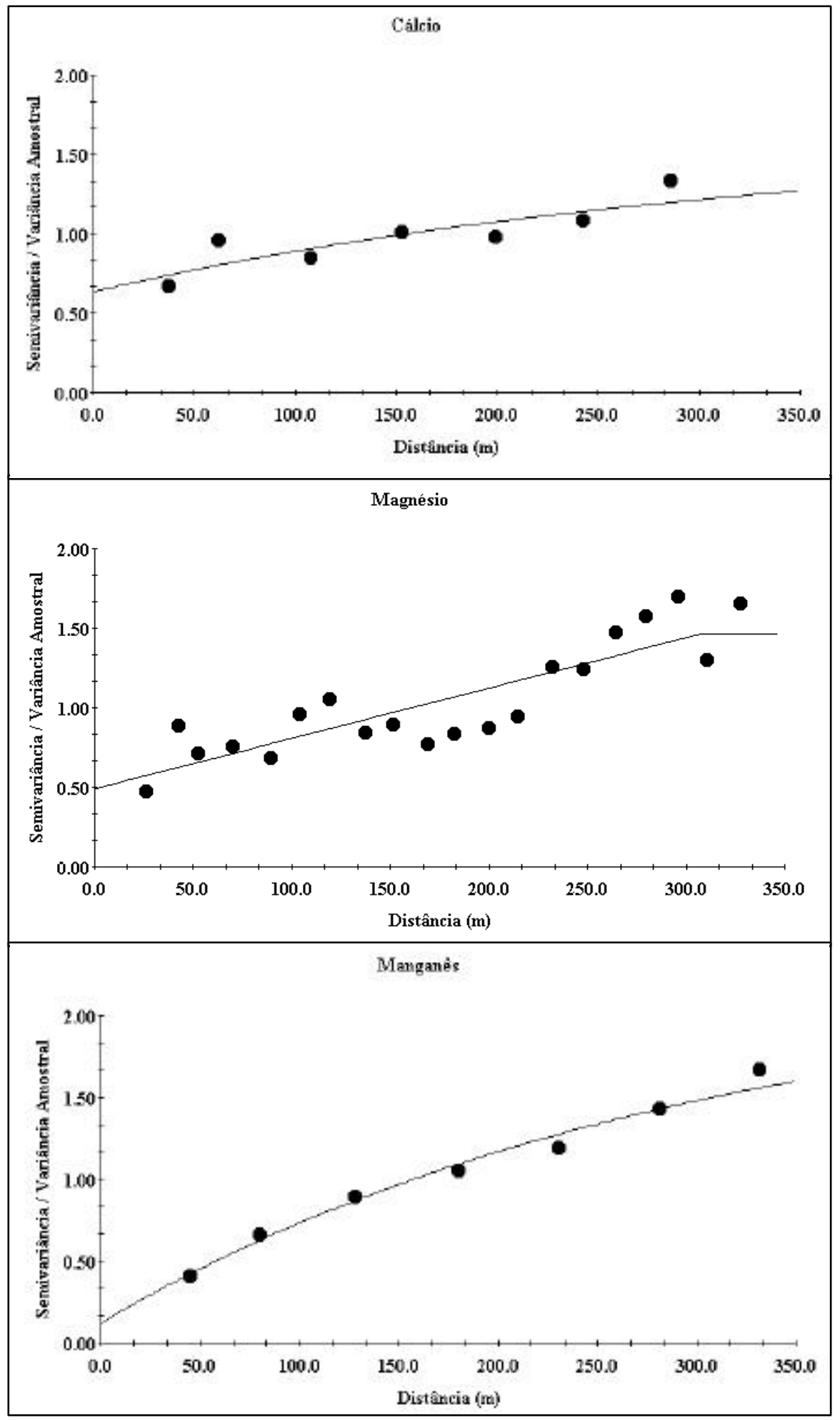

Figura 32 - Semivariogramas escalonados de Ca, Mg e Mn 


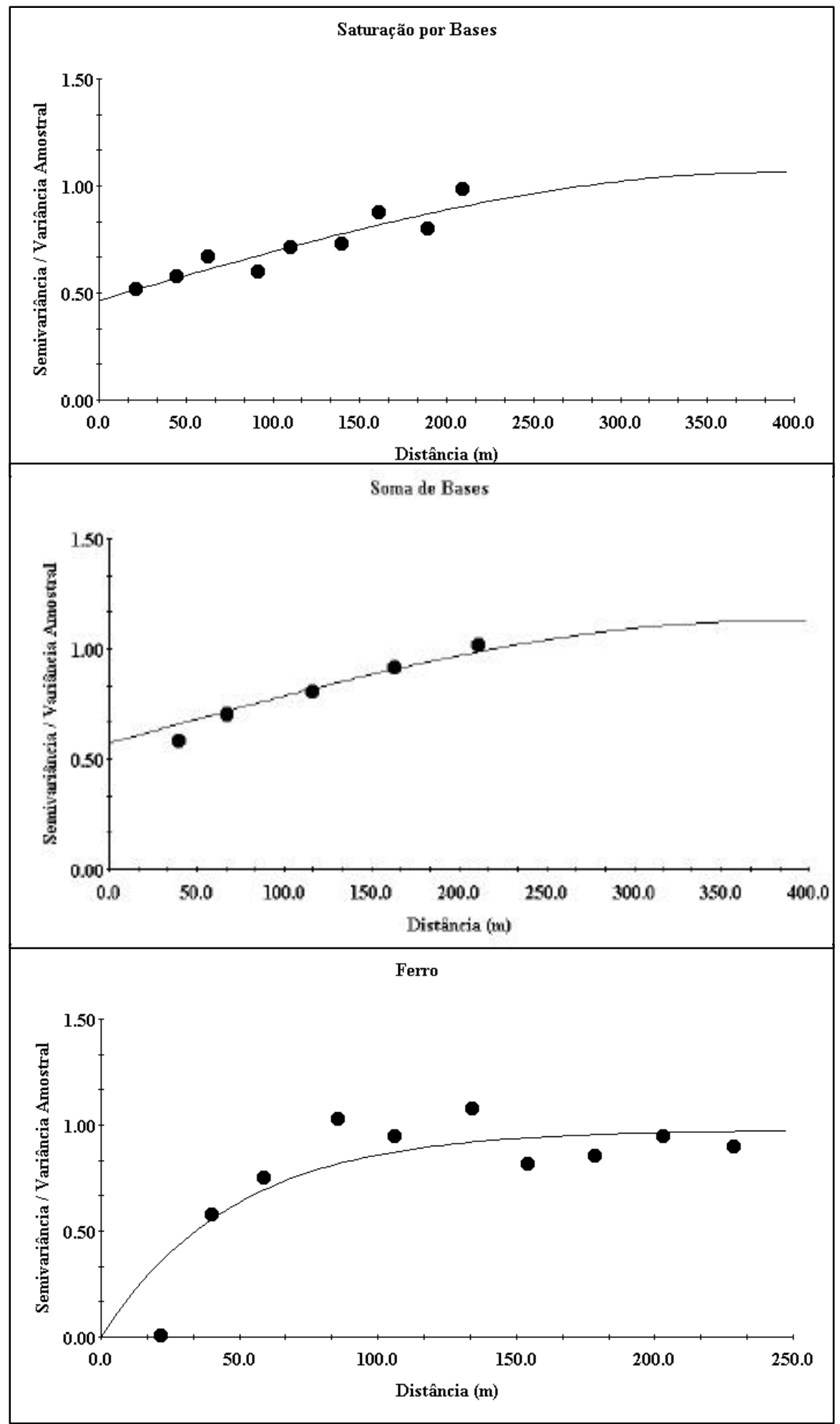

Figura 33 - Semivariogramas escalonados de V\%, SB e Fe 


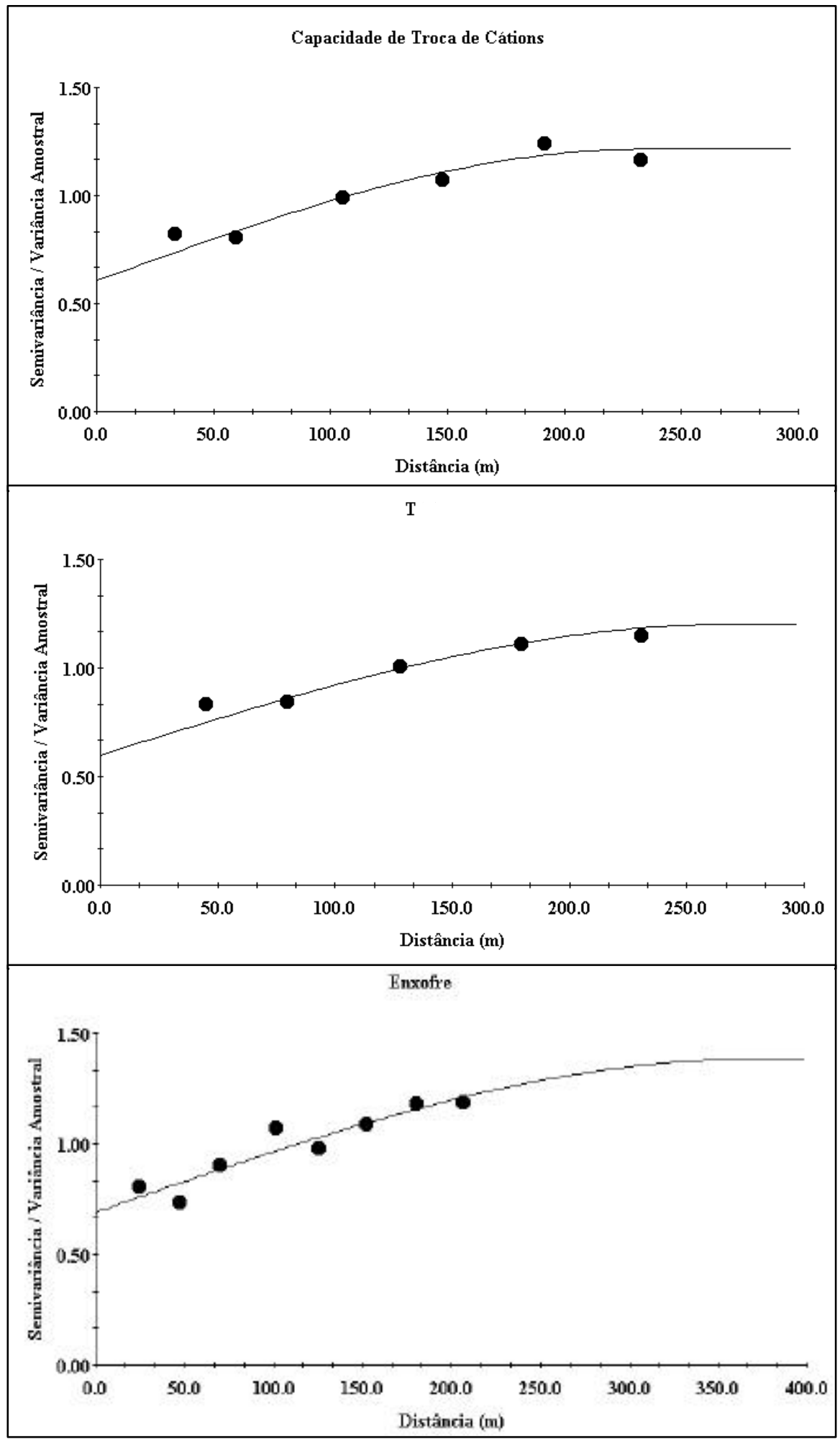

Figura 34 - Semivariogramas escalonados de CTC, T e S 


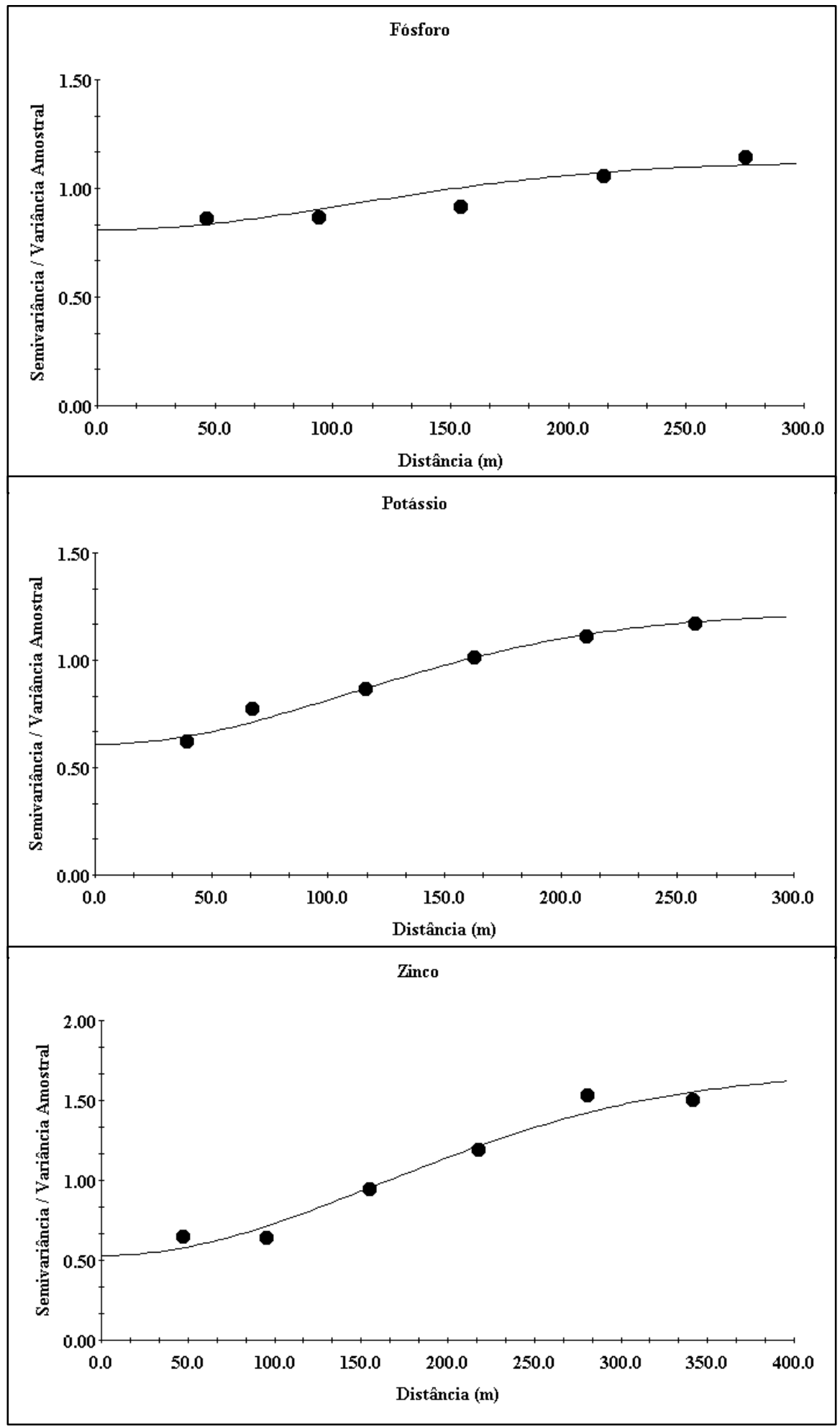

Figura 35 - Semivariogramas escalonados de P, Ke Zn 


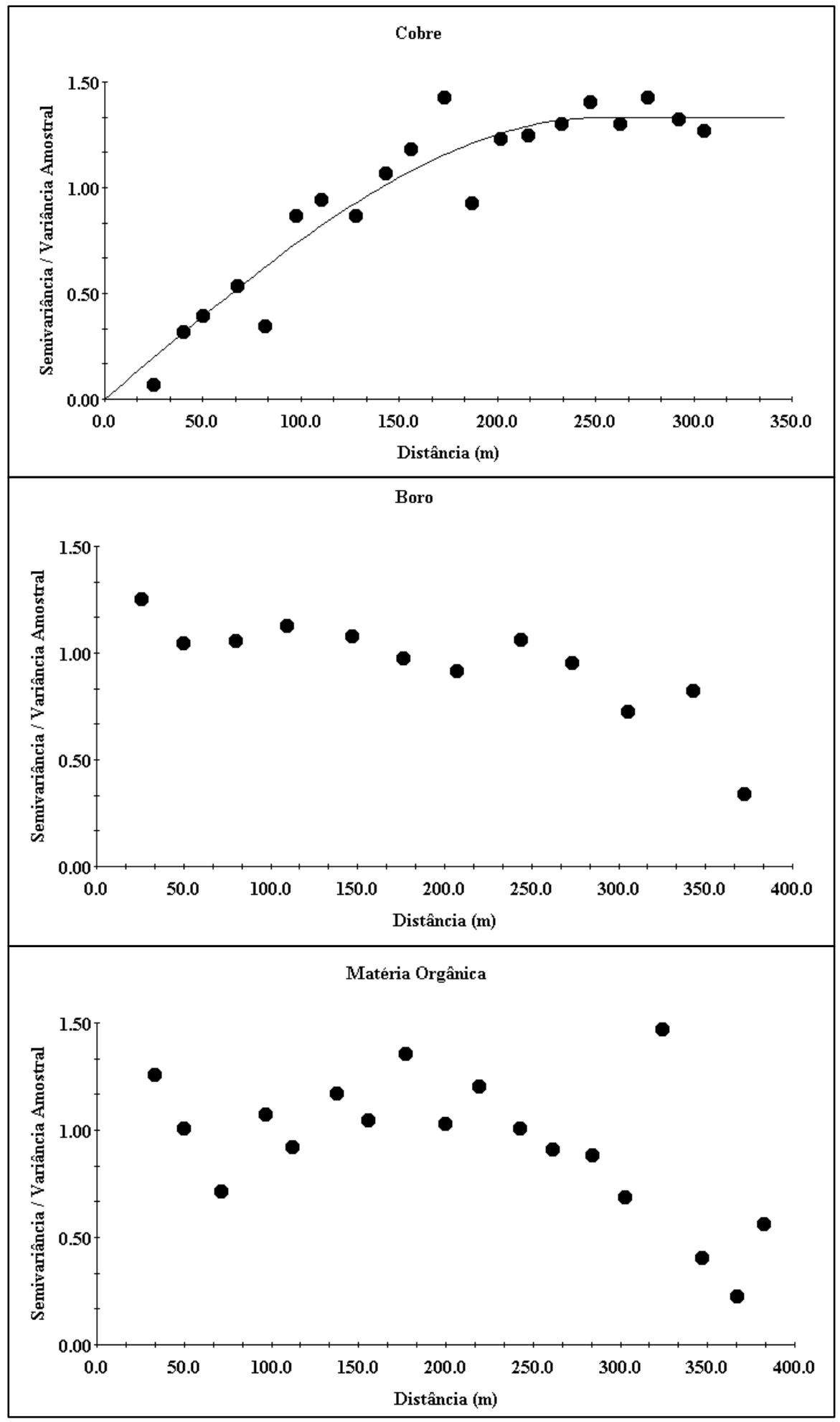

Figura 36 - Semivariogramas escalonados de Cu, B e MO 
Verifica-se que os semivariogramas de AreG, AreT, K e CTC apresentaram variabilidade espacial semelhante, ou seja, valores de efeito pepita, alcance e patamar próximos, indicando que provavelmente os processos que regulam estas variáveis na área de estudo são semelhantes no espaço, o que pode ser explicado por Costa \& Carmo (1985), que destacam a relação entre baixa CTC, solos de textura arenosa e deficiência em potássio.

Esse comportamento espacial semelhante também é verificado para CTC, SB, T e $\mathrm{V} \%$, e para $\mathrm{Al}, \mathrm{H}+\mathrm{Al}$ e m\%, o que já era esperado, uma vez que expressam grandezas semelhantes.

\subsubsection{Validação dos modelos ajustados}

A validação dos semivariogramas e a identificação do número ideal de vizinhos para a krigagem ordinária foram efetuadas por meio da análise do erro de estimativa, obtido com o procedimento de validação cruzada. Foi utilizado como parâmetro de decisão o erro de estimativa com média reduzida $\left(\mathrm{m}_{\text {. }}\right.$ ) igual a zero e variância reduzida $\left(\mathrm{s}^{2}\right.$ red) unitária. Na Tabela 15 são apresentados os resultados dos parâmetros da validação cruzada analisados. 
Tabela 15. Resultados dos parâmetros da validação cruzada para cada atributo

\begin{tabular}{|c|c|c|c|}
\hline Variável & Média Reduzida & Variância Reduzida & n- Vizinhos $^{\text {o }}$ \\
\hline AreG & $-0,005$ & 1,000 & $19 / 18$ \\
\hline ArMF & 0,002 & 0,996 & $9 / 8$ \\
\hline AreT & 0,004 & 0,910 & $23 / 22$ \\
\hline $\operatorname{Arg} A$ & 0,001 & 1,048 & $3 / 2$ \\
\hline $\operatorname{ArgT}$ & 0,000 & 0,998 & $16 / 15$ \\
\hline Cotas & 0,011 & 0,399 & $3 / 2$ \\
\hline IS & $-0,027$ & 0,877 & $4 / 3$ \\
\hline $\mathrm{Cu}$ & $-0,001$ & 0,868 & $5 / 4$ \\
\hline SilAr & $-0,005$ & 1,010 & $6 / 5$ \\
\hline Sil & 0,012 & 1,069 & $6 / 3$ \\
\hline $\mathrm{Zn}$ & $-0,009$ & 1,022 & $11 / 10$ \\
\hline $\mathrm{pH}$ & $-0,045$ & 1,000 & $4 / 3$ \\
\hline $\mathrm{P}$ & $-0,009$ & 1,008 & $21 / 20$ \\
\hline $\mathrm{K}$ & $-0,003$ & 1,067 & $17 / 16$ \\
\hline $\mathrm{Mg}$ & 0,003 & 1,110 & $3 / 2$ \\
\hline $\mathrm{Fe}$ & 0,002 & 1,014 & $8 / 7$ \\
\hline Floc & 0,000 & 1,012 & $9 / 8$ \\
\hline $\mathrm{S}$ & 0,014 & 0,917 & $22 / 21$ \\
\hline $\mathrm{Mn}$ & $-0,038$ & 0,913 & $8 / 7$ \\
\hline $\mathrm{ArF}$ & 0,003 & 1,032 & $17 / 16$ \\
\hline ArMG & 0,006 & 1,032 & $15 / 14$ \\
\hline CTC & 0,000 & 1,069 & $17 / 16$ \\
\hline $\mathrm{Ca}$ & $-0,017$ & 1,159 & $23 / 22$ \\
\hline $\mathrm{Al}$ & 0,008 & 1,073 & $17 / 16$ \\
\hline SB & $-0,014$ & 1,108 & $23 / 22$ \\
\hline $\mathrm{m}$ & 0,035 & 1,040 & $3 / 2$ \\
\hline $\mathrm{V}$ & $-0,010$ & 1,159 & $23 / 22$ \\
\hline $\mathrm{T}$ & 0,006 & 1,024 & $15 / 14$ \\
\hline $\mathrm{H}+\mathrm{Al}$ & 0,015 & 1,098 & $15 / 14$ \\
\hline ArM & 0,045 & 1,132 & $4 / 3$ \\
\hline Umi & $-0,002$ & 1,050 & $19 / 18$ \\
\hline
\end{tabular}


Nota-se que os valores obtidos para o erro de estimativa apresentam média e variância muito próximos a 0 e 1, respectivamente. Os valores obtidos para a média reduzida são, no geral, muito próximos, variando de $-0,045$ a 0,045 , podendo ser considerados como excelentes. $\mathrm{O}$ mesmo pode-se dizer para os valores obtidos para a variância reduzida que, sem considerar a variável cotas, variou de 0,868 a 1,159. No trabalho de Gonçalves (1997) os semivariogramas ajustados para areia e argila apresentando variância reduzida igual a 1,5 e 1,6, respectivamente, foram validados. Garcia Y Garcia (1997) validou o semivariograma ajustado para argila e areia com variâncias reduzidas, respectivamente, iguais a 1,218 e 1,177, assim como o de potencial mátrico que apresentou variância reduzida igual a 1,361 e média reduzida igual a -0,067. Considerando todas as variáveis, cotas foi a que apresentou o valor para variância reduzida $(0,399)$ mais distante de 1 . Comparado com os demais valores obtidos, este valor parece discrepante do ideal, porém também pode ser considerado como excelente, o que é confirmado pelo mapa dos erros (Figura 37) e pelos gráficos do erro de estimativa da validação cruzada (Figuras 38 e 39) obtidos no Geoeas.

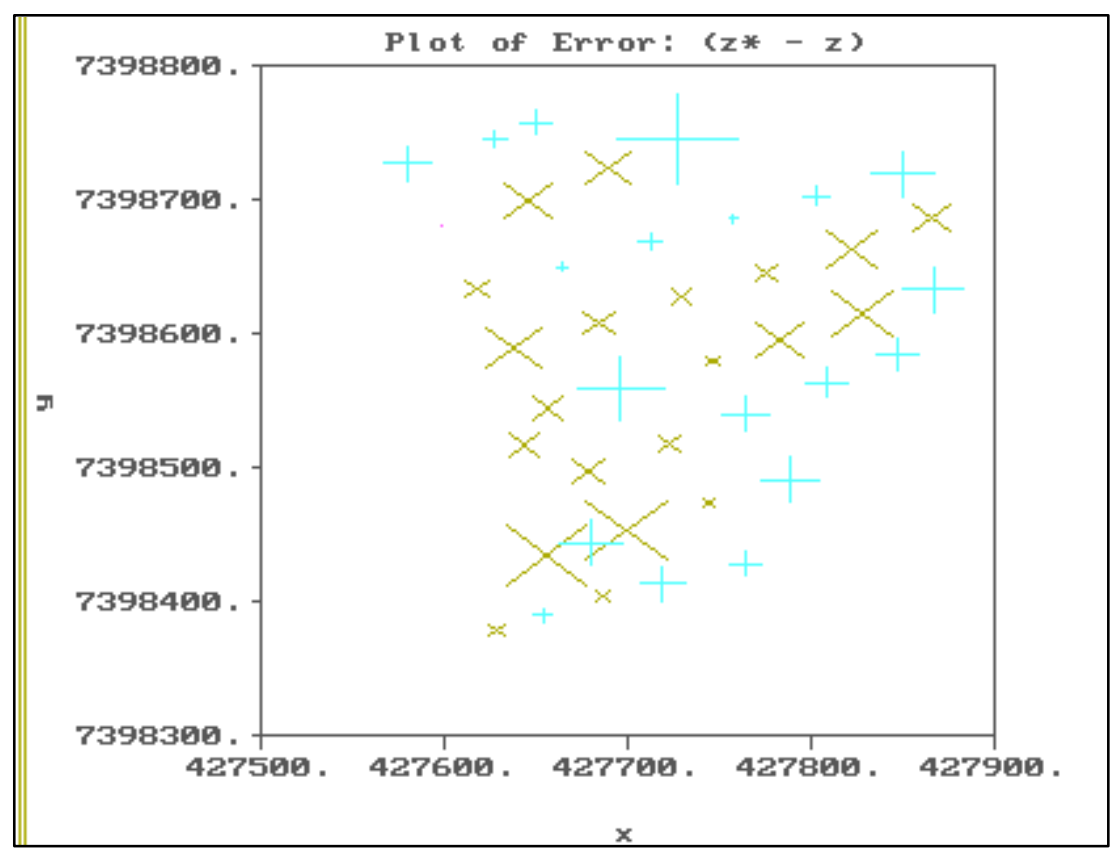

Figura 37 - Mapa dos erros da validação cruzada para Cotas 
O mapa dos erros indica uma uniformidade dos erros da krigagem, sendo o número de observações com valores superestimados (+) igual ou próximo ao de subestimados (x), assim como distribuição aleatória dos erros, não ocorrendo, no geral, concentrações de superestimativas e subestimativas em determinadas regiões do mapa.

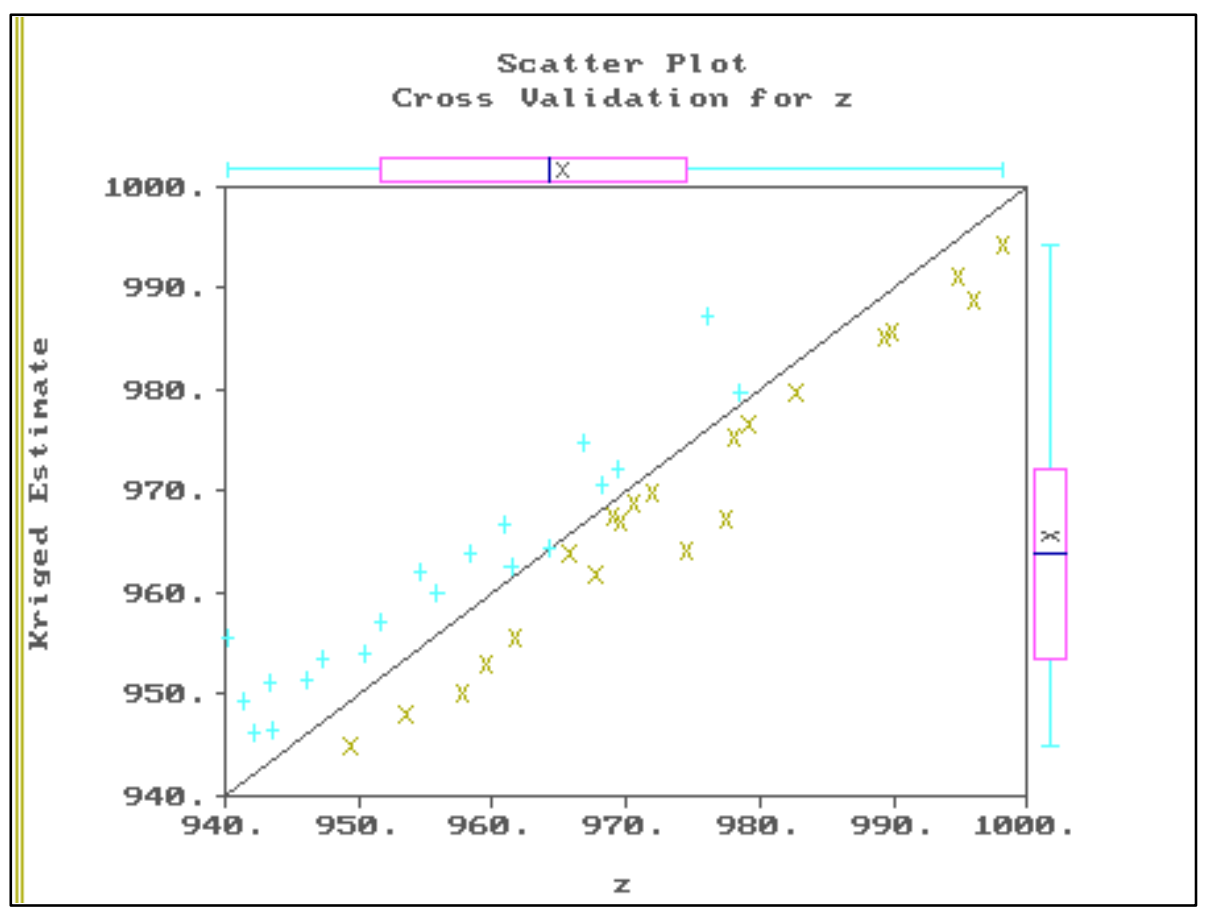

Figura 38 - Gráfico do erro de estimativa para Cotas

O gráfico do erro de estimativa ("scatter plot") com os valores observados (eixo x) e estimados (eixo y) mostra que há um equilíbrio entre subestimativa (x) e superestimativa $(+)$ e que ambos estão próximos à reta $1: 1$, fatos que indicam um nãoviés do estimador, ou seja, o estimador utilizado pode ser considerado como de boa qualidade. 


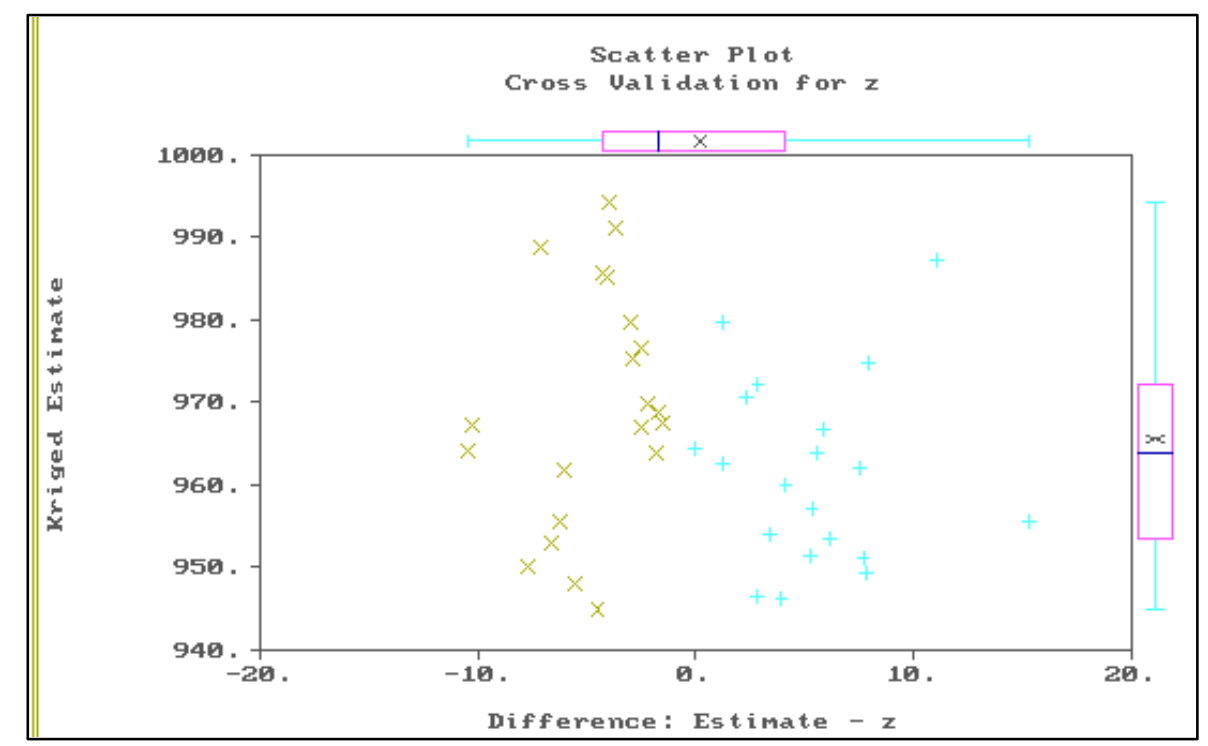

Figura 39 - Gráfico do erro de estimativa para Cotas

Nesta outra forma do gráfico do erro de estimativa ("scatter plot"), com os valores do erro da estimativa (eixo x) e dos valores estimados (eixo y), mostra que o comportamento é de certa forma simétrico, com um número de valores superestimados (+) igual ou próximo ao de subestimados (x), e que os erros estão concentrados em torno de zero, indicando que o estimador não tende a subestimar ou superestimar.

A qualidade do ajuste do semivariograma para cotas foi por fim testada por meio de regressão linear simples entre os valores observados e estimados, no GS+, analisandose o valor do coeficiente de determinação $\left(\mathrm{r}^{2}\right)$ (Figura 40). A situação encontrada, utilizando 41 vizinhos, é muito próxima da ideal, com valor de $\mathrm{r}^{2}=93 \%$ e com o gráfico de dispersão entre os valores estimados e medidos apresentando a aderência dos pontos próximos ou sobre a reta 1:1, além do equilíbrio entre valores sub e superestimados pela krigagem, evidenciado pelo fato dos dois lados da diagonal da reta 1:1 apresentarem um número aproximadamente igual de observações. 


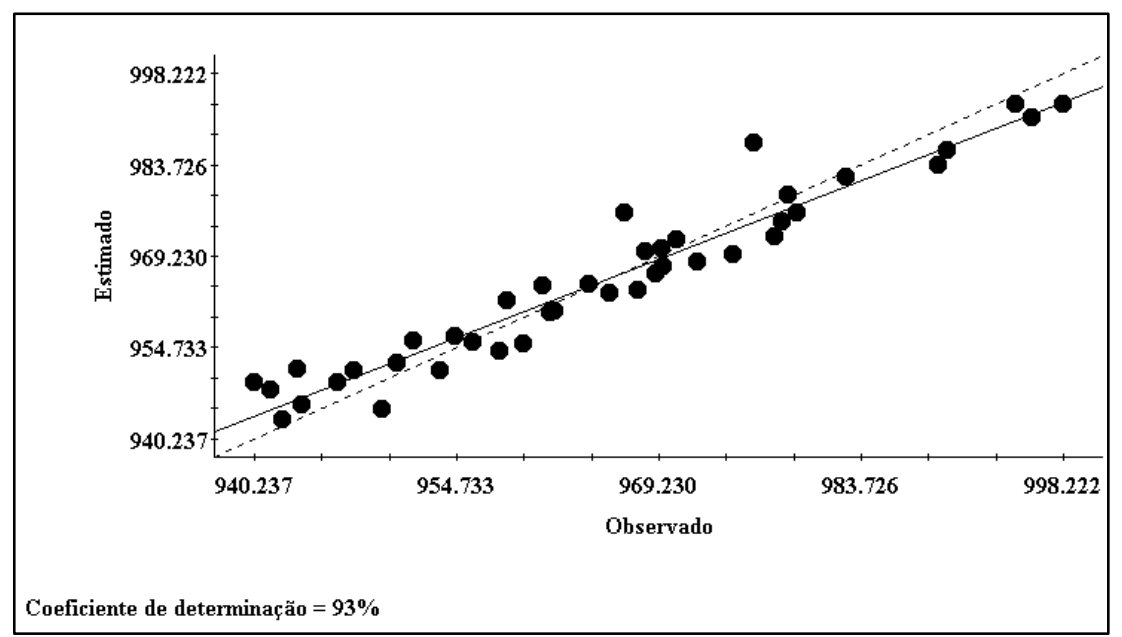

Figura 40 - Regressão linear entre valores observados e estimados para Cotas

\subsubsection{Mapeamento digital}

A obtenção de informações a respeito da variabilidade espacial das plantas, atributos topográficas e do solo foi possível a partir do mapeamento desta variabilidade com o uso da interpolação pela técnica da krigagem ordinária, a qual estimou, sem tendenciosidade e com mínima variância, valores de um atributo para locais não amostrados, a partir da interpolação dos valores amostrados. A obtenção de uma malha de pontos interpolados permitiu visualizar o comportamento das variáveis estudadas na área por meio de mapas de isolinhas, ou contorno, e de superfícies contínuas, ou modelo numérico de terreno (MNT), recursos importantes para o manejo diferenciado de áreas. Para a interpolação por krigagem, no Surfer, foram utilizados os parâmetros geoestatísticos obtidos para cada semivariograma na forma não escalonada.

Nas figuras a seguir (Figuras 41 a 53) pode-se verificar a distribuição espacial das variáveis na área de estudo. A análise dos mapas possibilitou a distinção de regiões com menor e maior variabilidade dos atributos estudados, o que permite a divisão de áreas em subáreas de maior e menor variabilidade, possibilitando o manejo de forma individualizada, diferenciada e localizada, implicando num maior nível de acurácia e eficiência dessa atividade. 

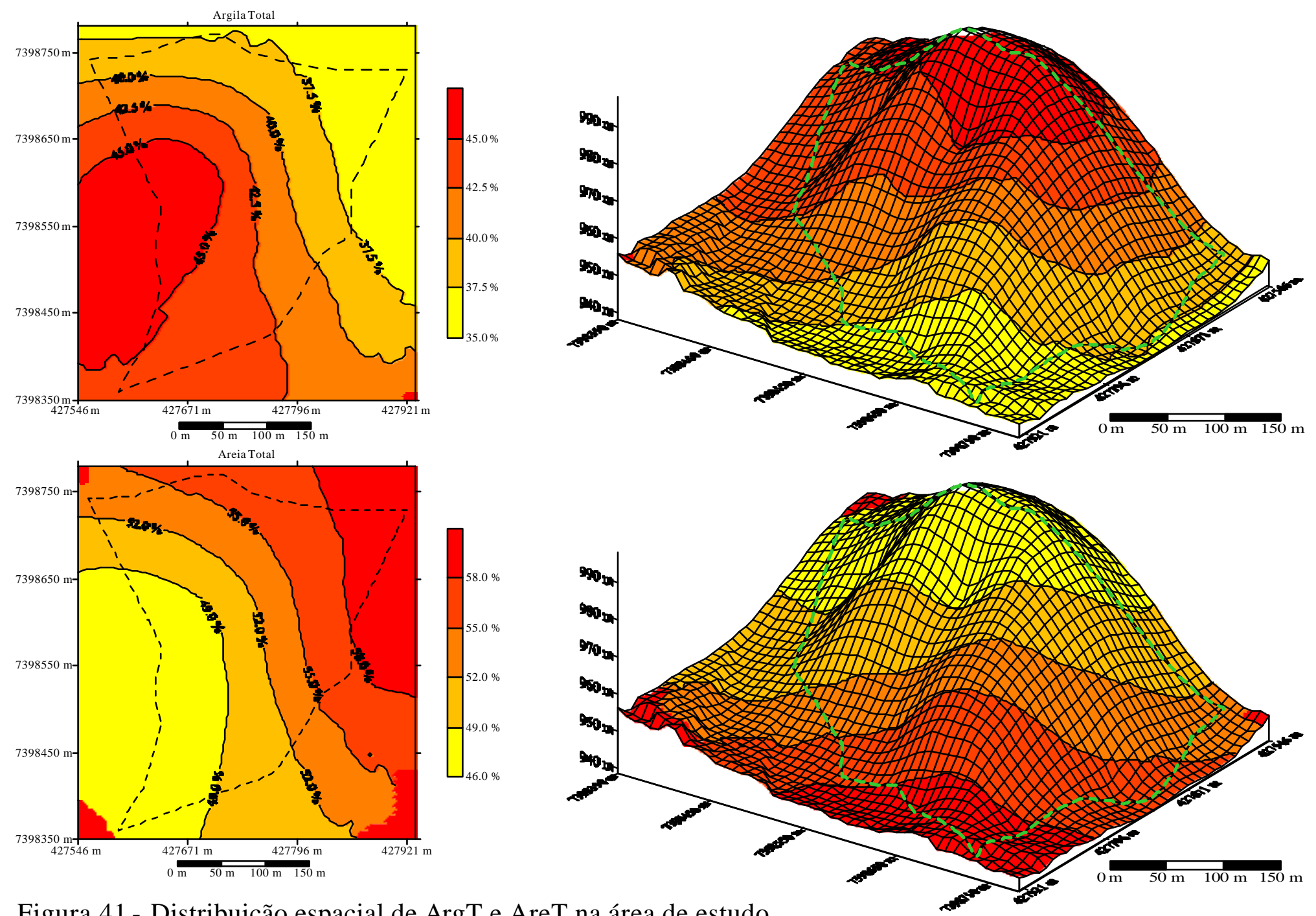

Figura 41 - Distribuição espacial de ArgT e AreT na área de estudo 

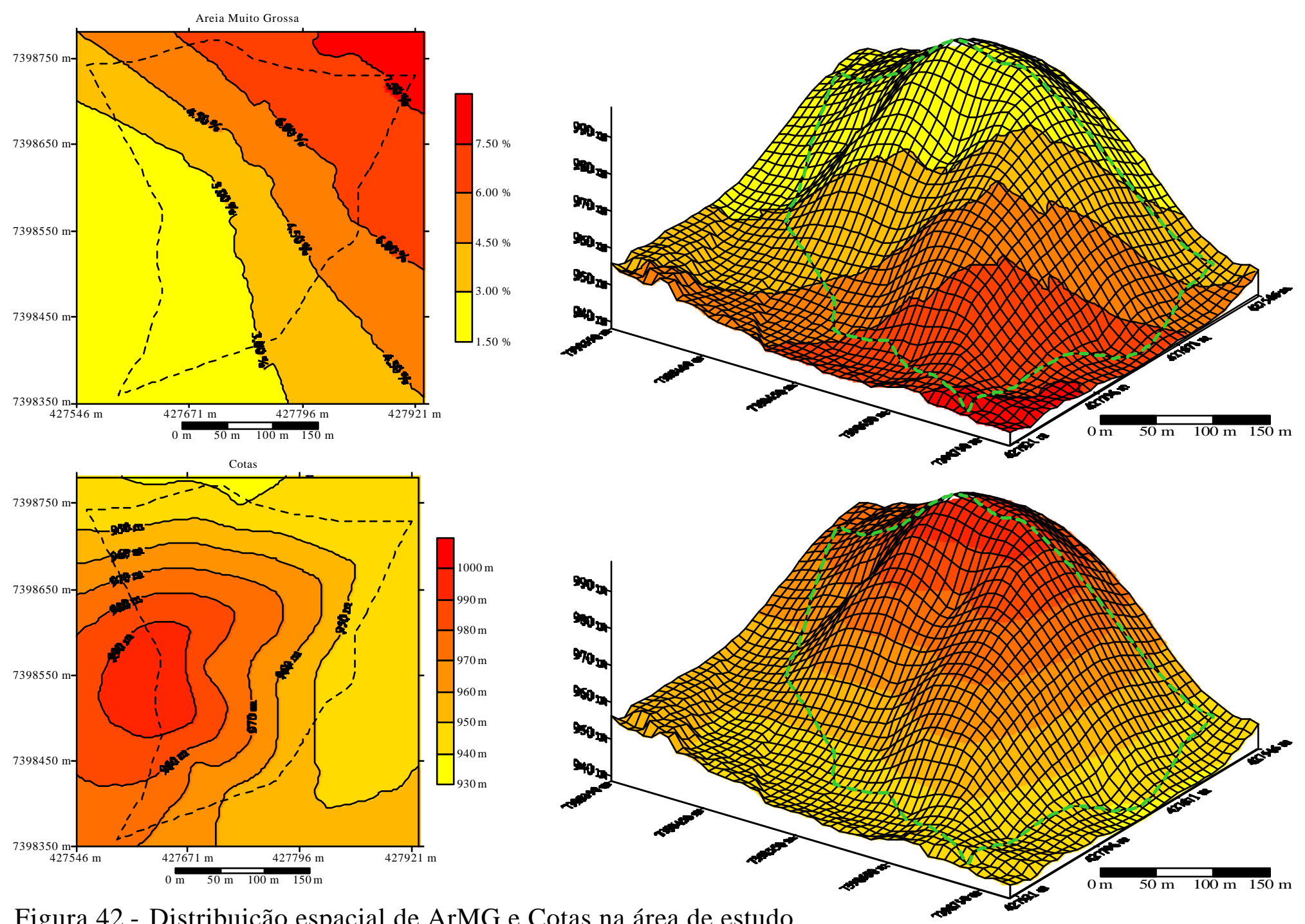

Figura 42 - Distribuição espacial de ArMG e Cotas na área de estudo 

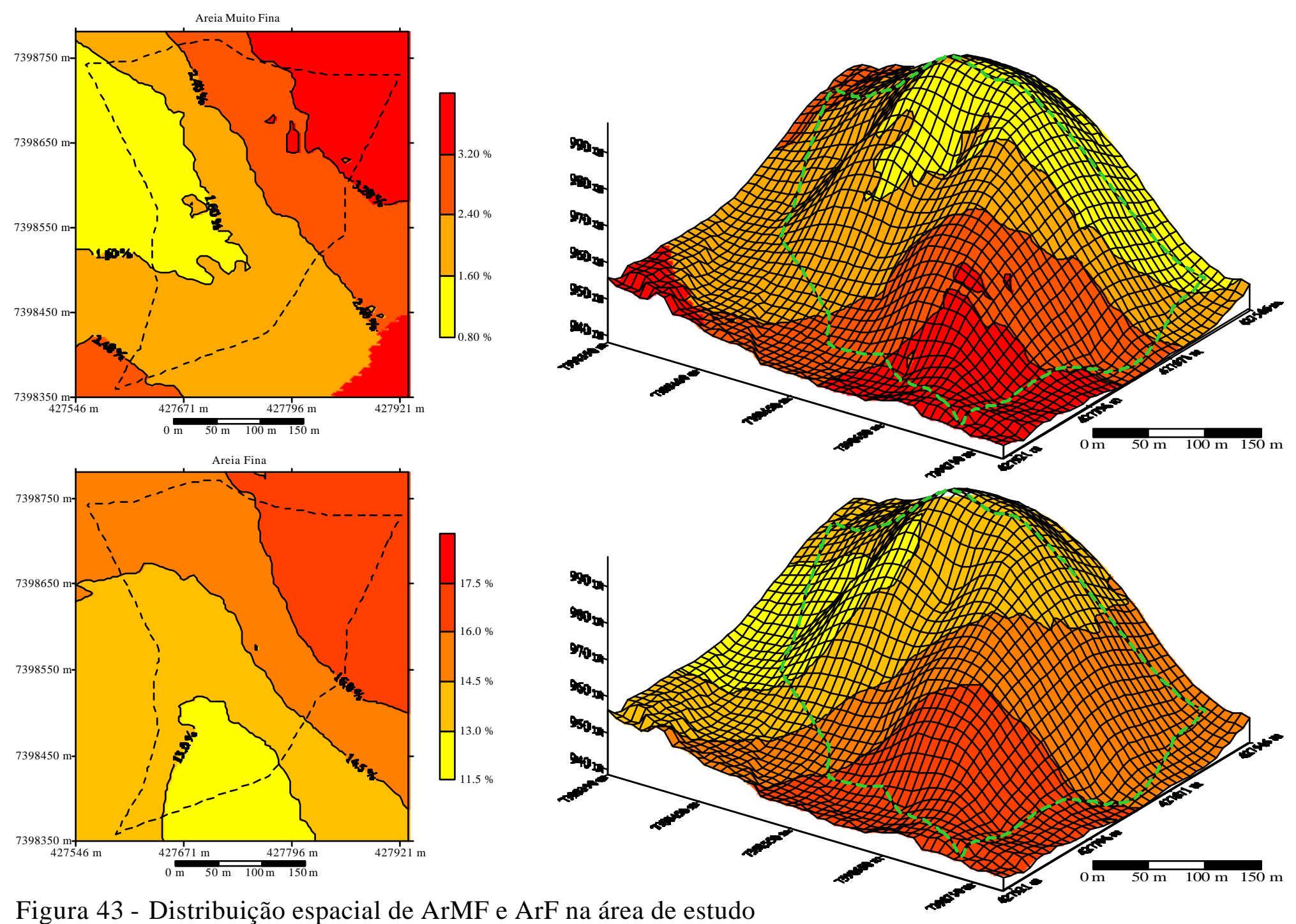

Figura 43 - Distribuição espacial de ArMF e ArF na área de estudo 

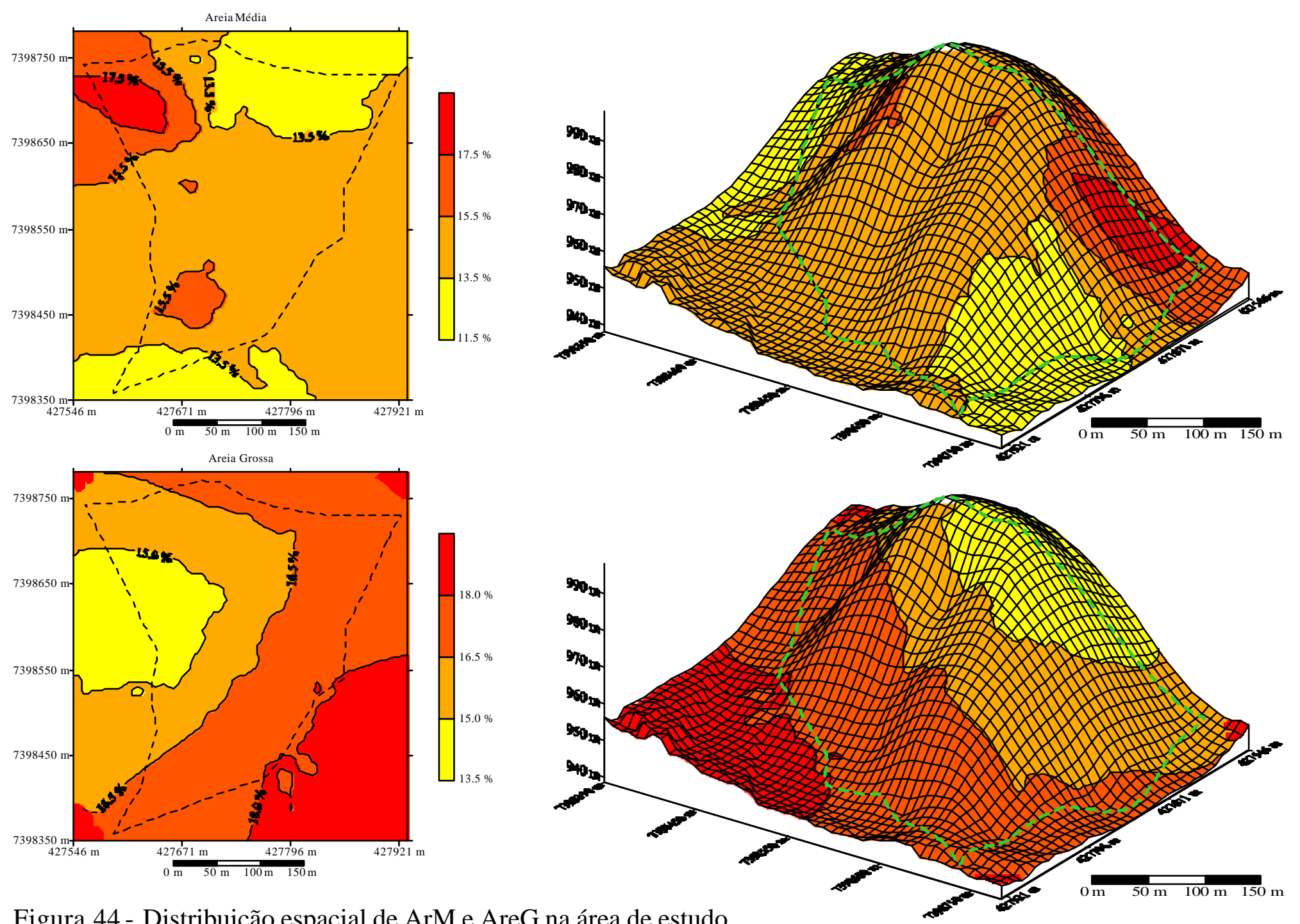

Figura 44 - Distribuição espacial de ArM e AreG na área de estudo 

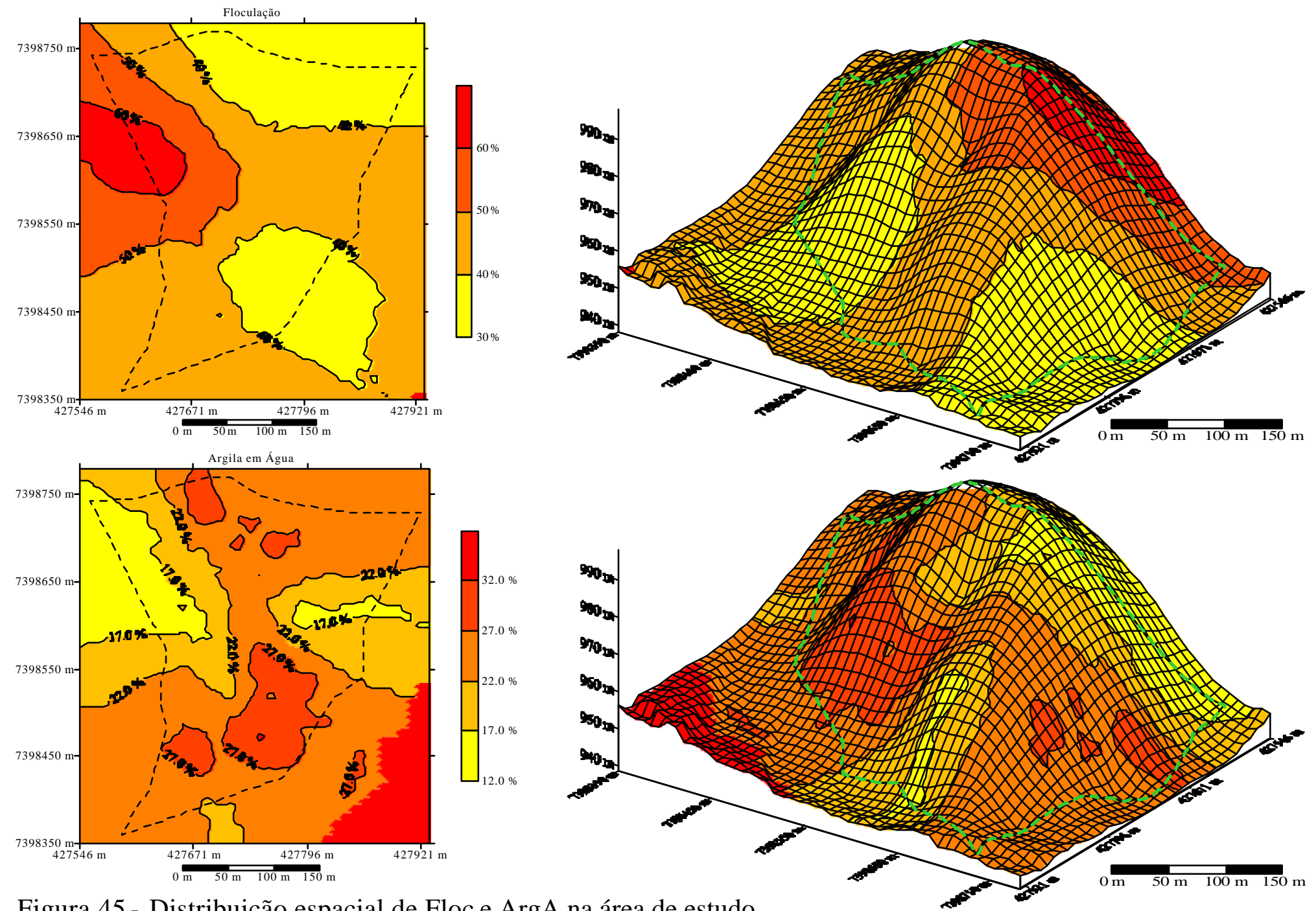

Figura 45 - Distribuição espacial de Floc e ArgA na área de estudo 

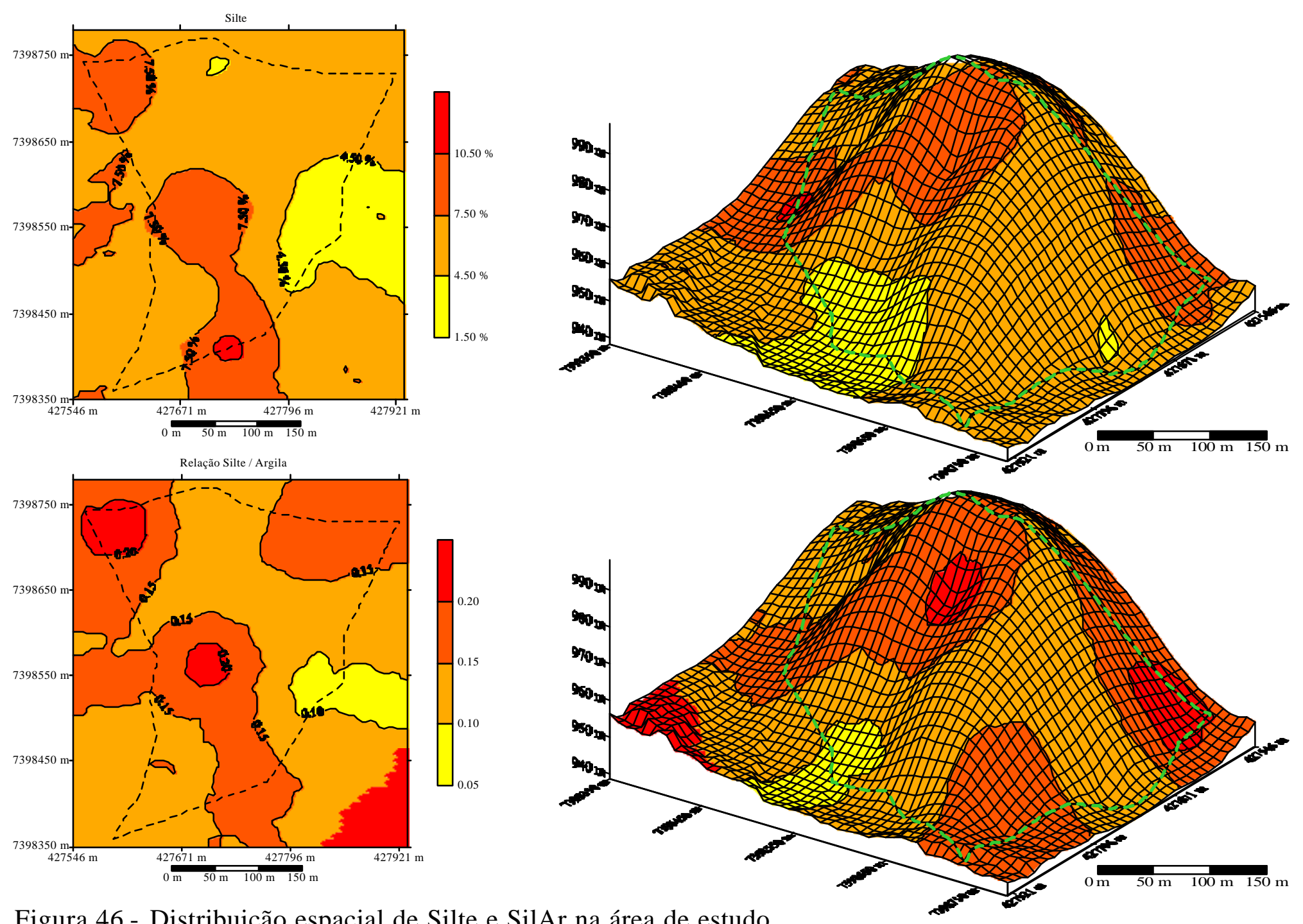

Figura 46 - Distribuição espacial de Silte e SilAr na área de estudo 

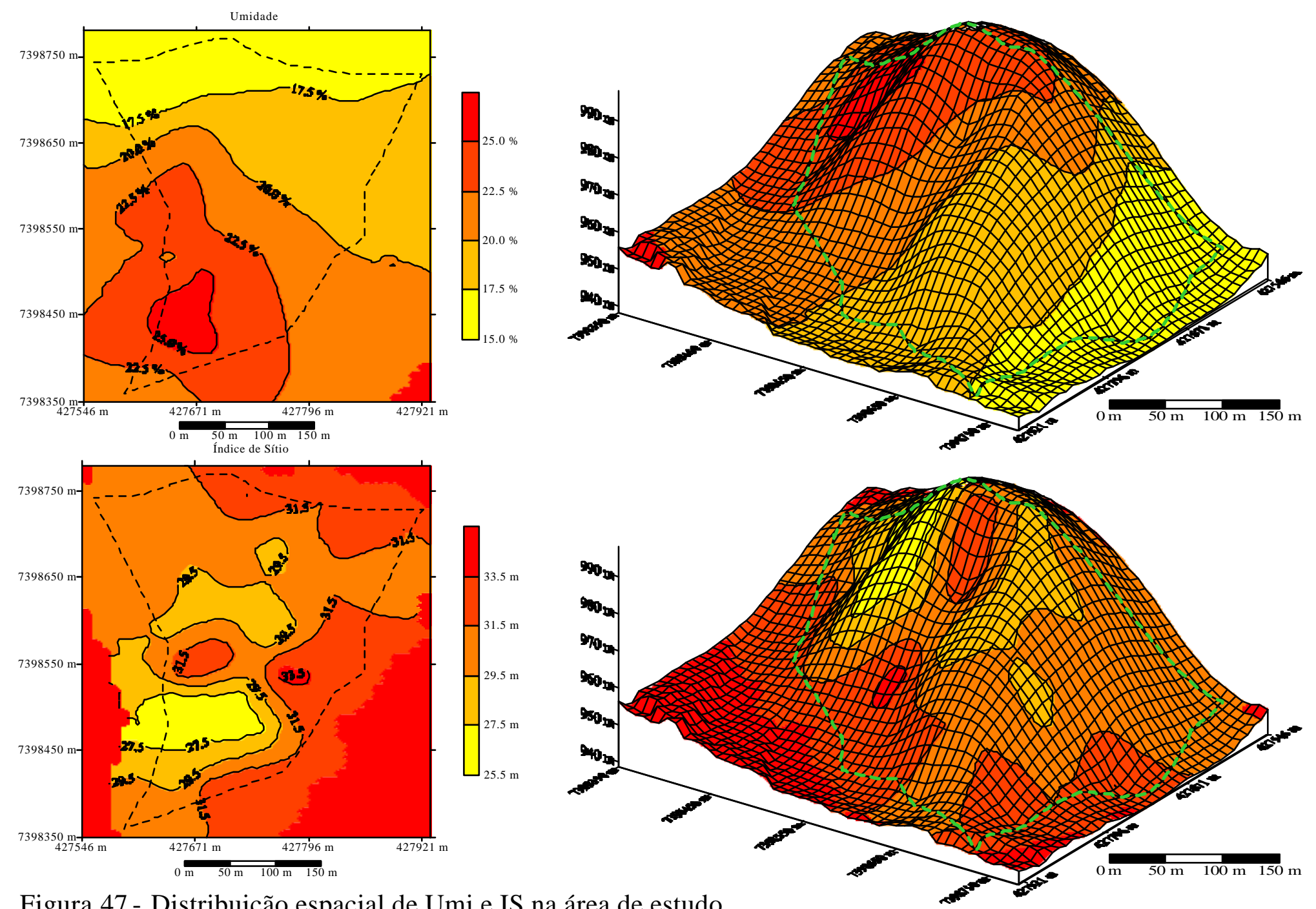

Figura 47 - Distribuição espacial de Umi e IS na área de estudo 

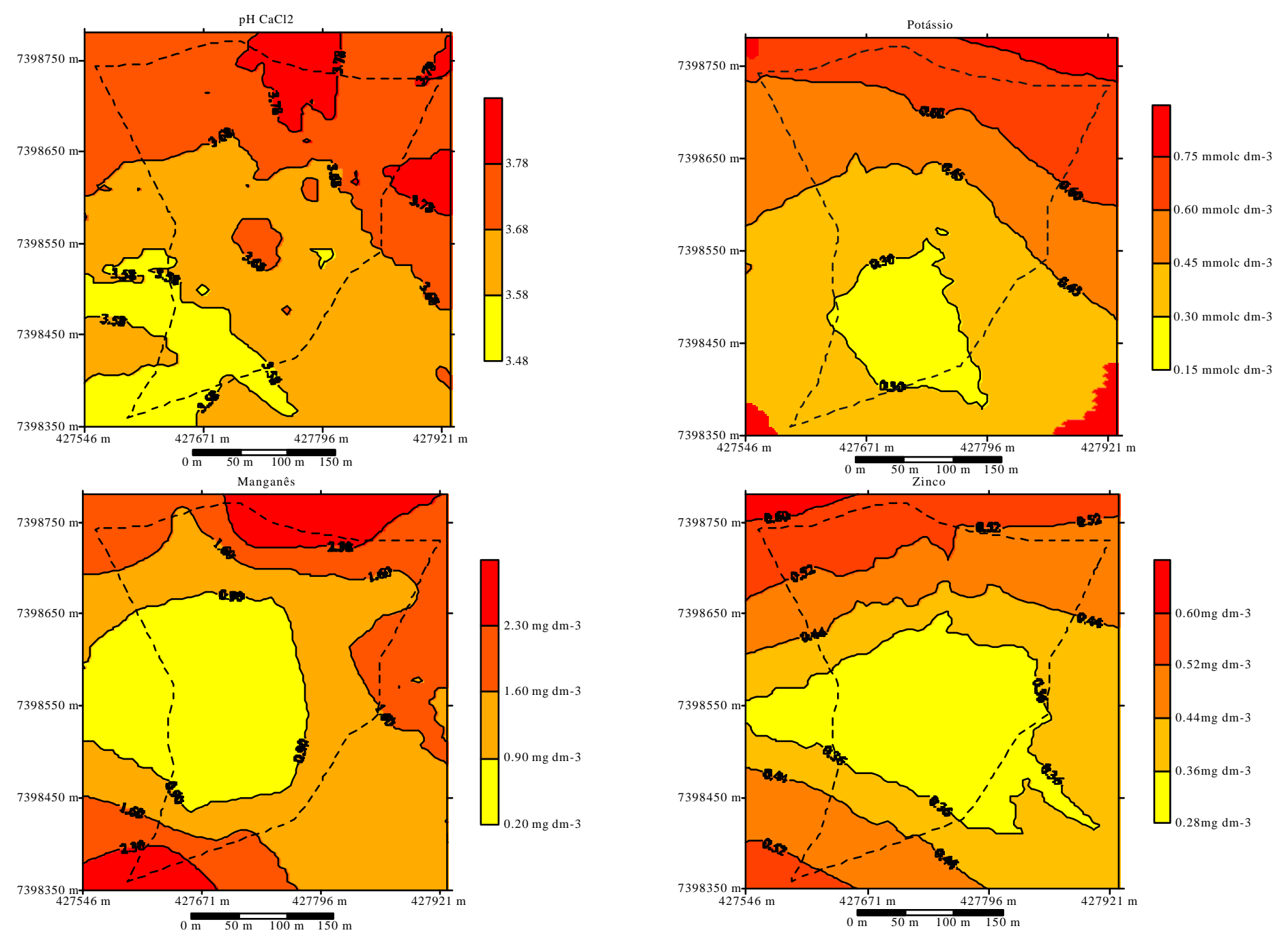

Figura 48 - Distribuição espacial de pH, K, Mn e Zn na área de estudo 

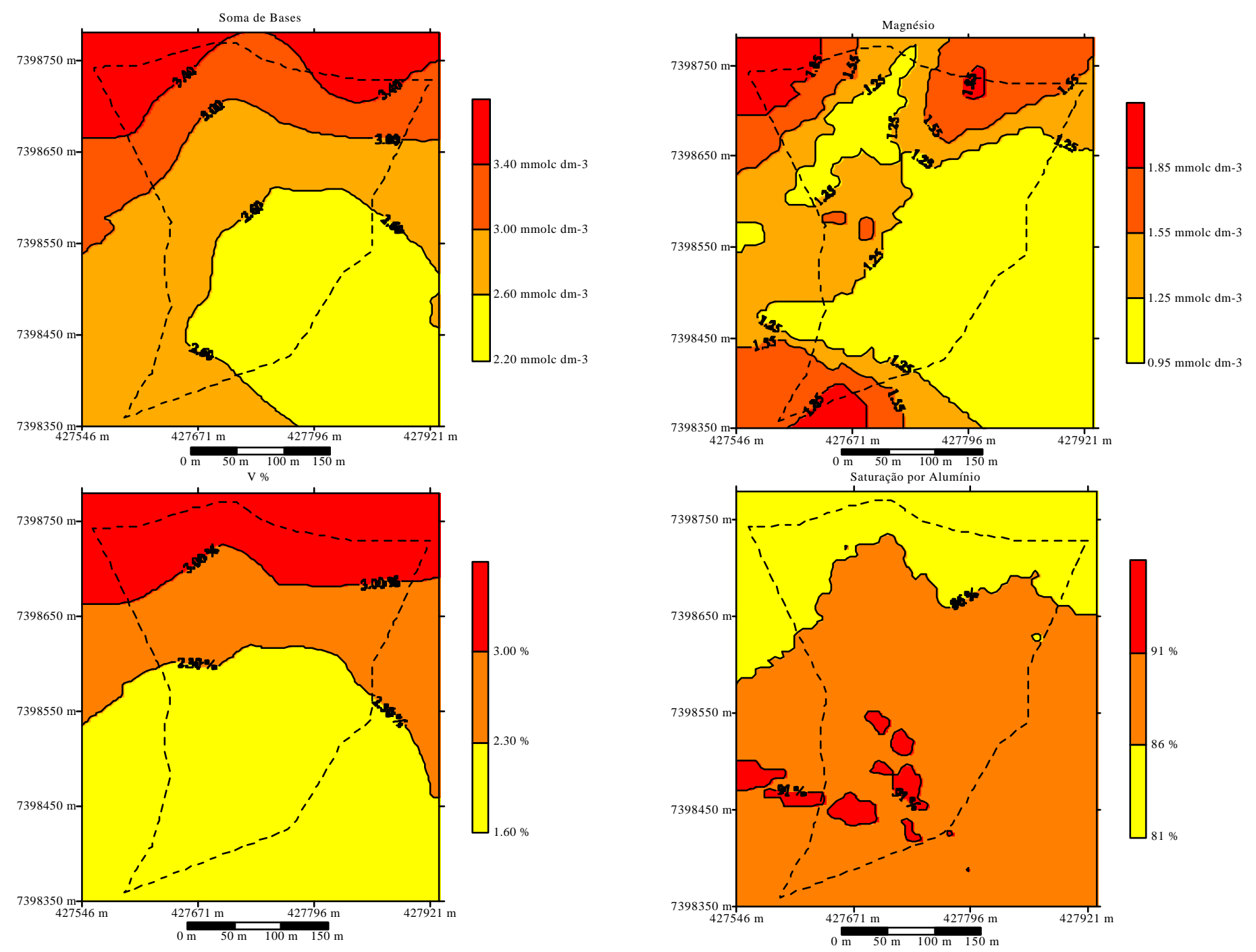

Figura 49 - Distribuição espacial de SB, Mg, V\% e m\% na área de estudo 

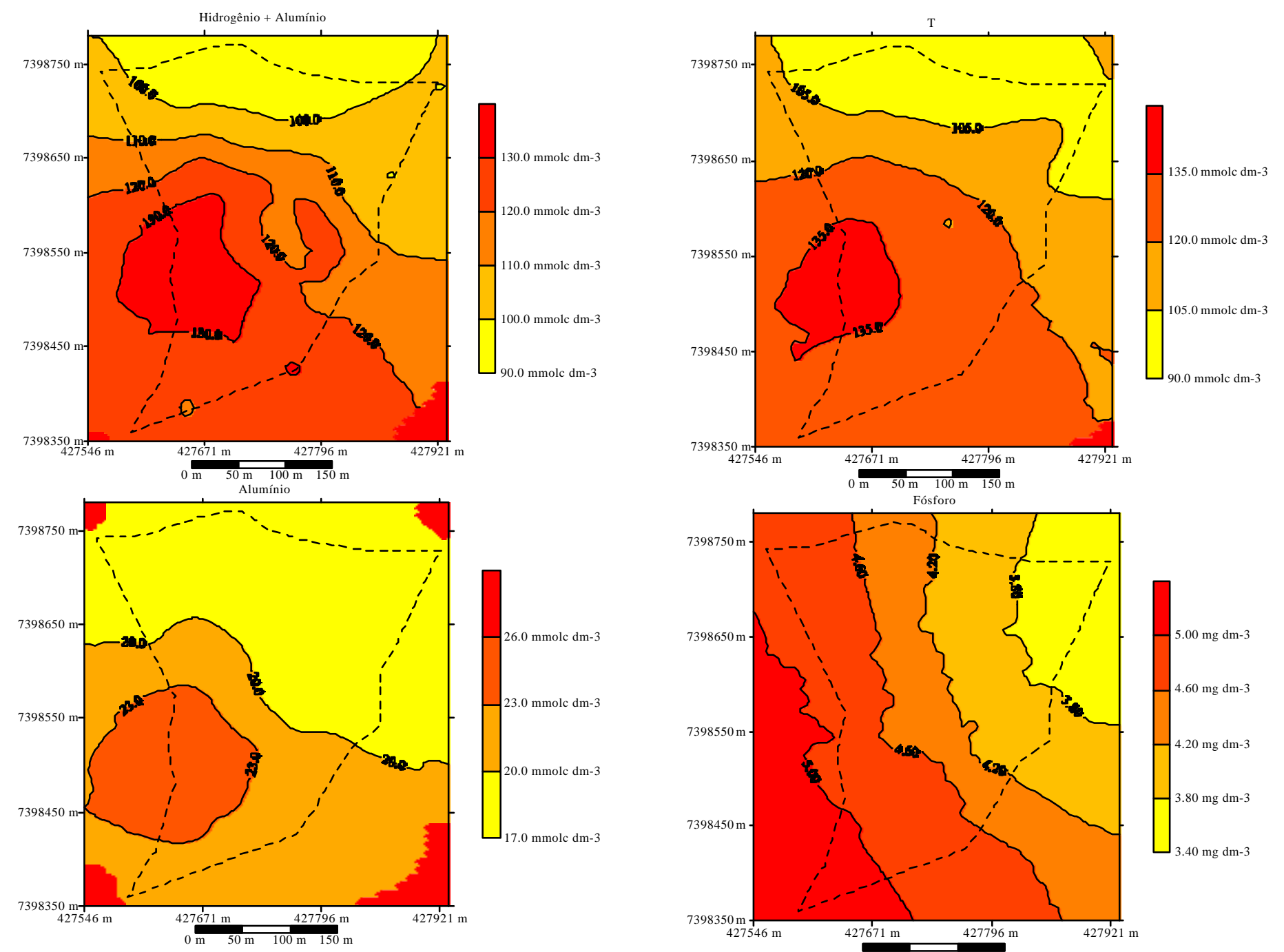

Figura 50 - Distribuição espacial de H+Al, T, Al e P na área de estudo 

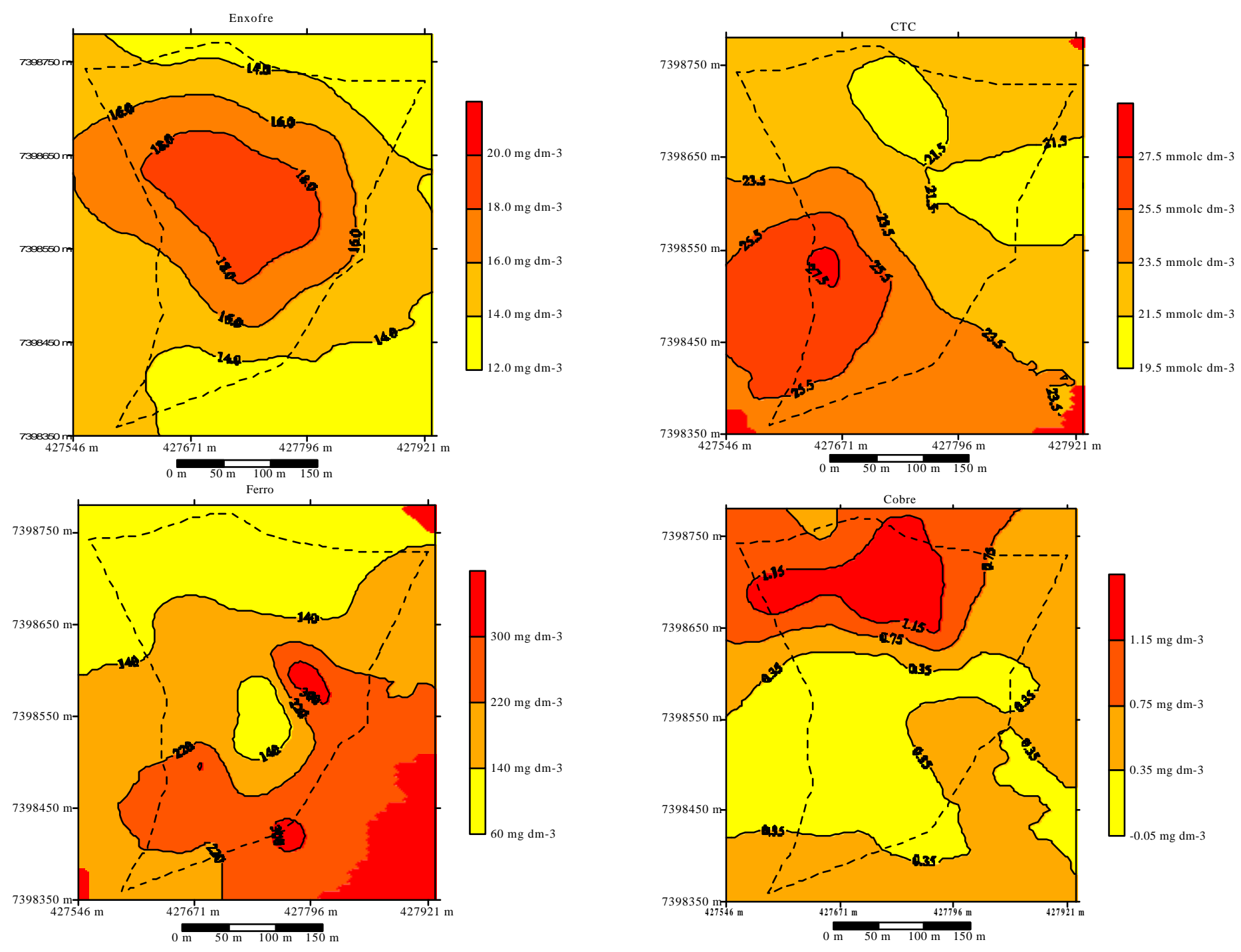

Figura 51 - Distribuição espacial de S, CTC, Fe e Cu na área de estudo 

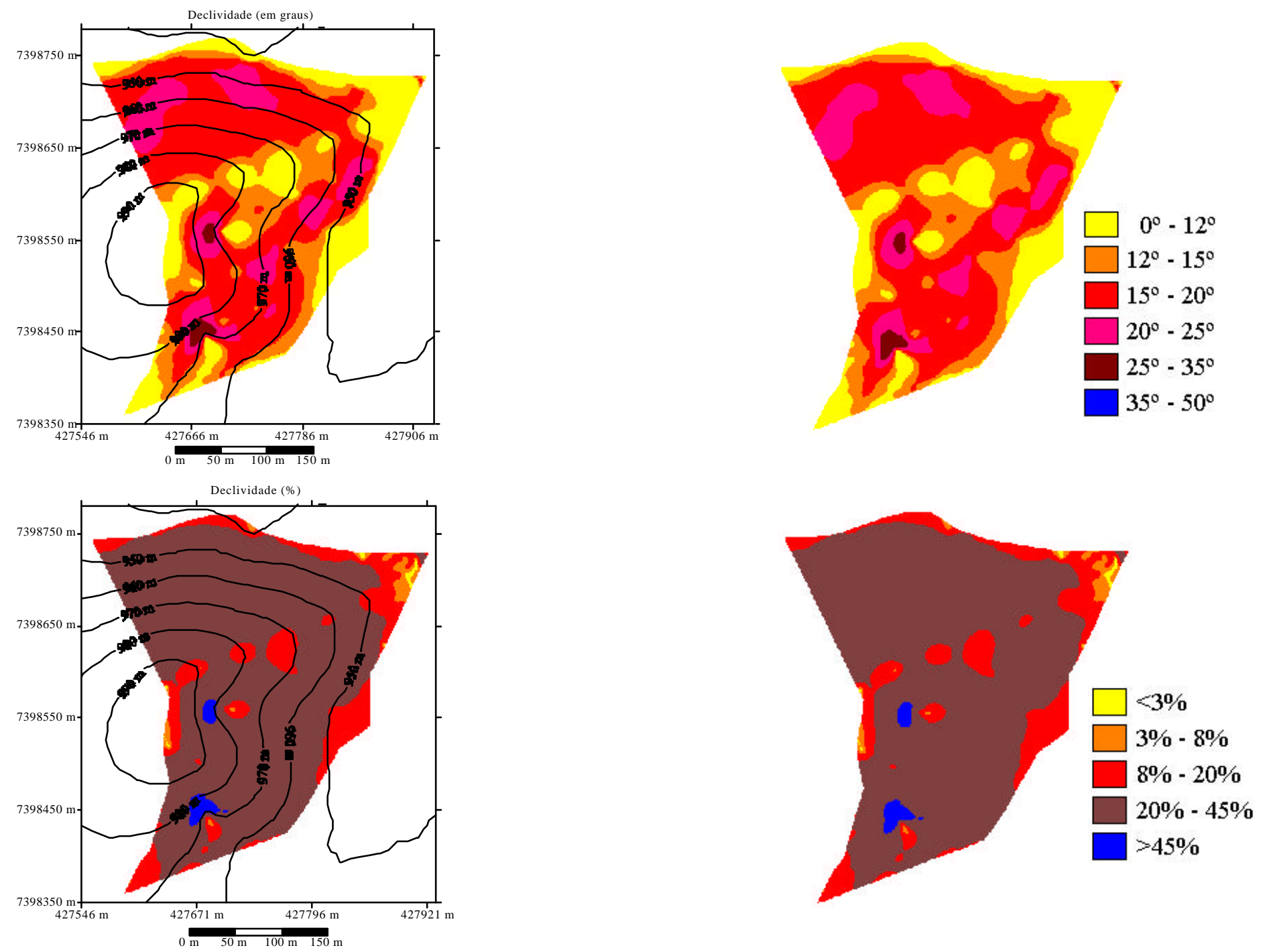

Figura 52 - Localização das classes de declividade, em graus e porcentagem, na área de estudo 

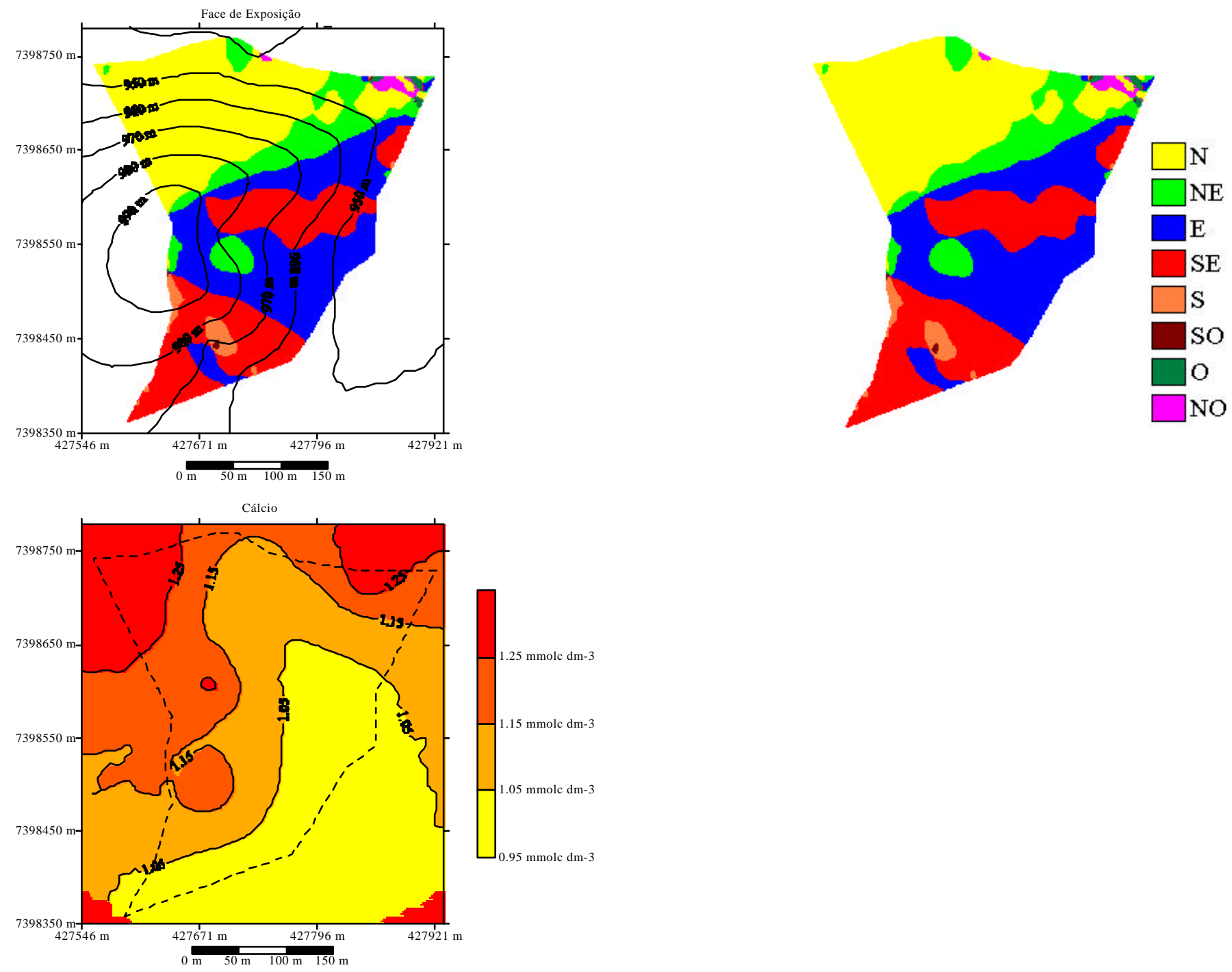

Figura 53 - Localização das faces de exposição e distribuição espacial de Ca na área de estudo 
Observa-se nas figuras que, para $\mathrm{Mn}, \mathrm{Zn}, \mathrm{V} \%, \mathrm{~K}, \mathrm{SB}$, areia total, muito grossa e grossa há uma mudança gradual do teor, no geral, maior nas cotas mais baixas e menor nas mais altas; o inverso para $\mathrm{P}, \mathrm{Al}, \mathrm{T}, \mathrm{H}+\mathrm{Al}, \mathrm{m} \%, \mathrm{CTC}$, argila total e umidade. É importante lembrar que as cotas mais baixas da face Sul são maiores que as mais baixas das faces Norte e Nordeste, sendo que estas também apresentam desnível maior, ou seja, a distância entre o topo e a baixada é maior.

Nota-se que as menores porcentagens de umidade estão concentradas nas faces Norte e Nordeste e as maiores na face Sul, visto que foram verificadas naquelas, maiores porcentagens de areia total, muito grossa e grossa, menor de argila total e maior de insolação, o que acarreta maior evaporação da água no solo e evapotranspiração da planta.

Analisando-se a Figura 47, com a distribuição espacial do índice de sítio, verificase que as baixadas apresentaram maior área com capacidade produtiva alta do que baixa, ao contrário dos topos de morro.

Todos estes resultados concordam com as afirmações, já apresentadas anteriormente, por meio da análise de correlação, regressão linear simples e múltipla, assim como com as de Barros (1974), Schonau \& Aldworth (1991), Shorter (1993) e Grespan (1997), os quais também encontraram relação positiva entre crescimento do eucalipto e teor de areia e negativa entre crescimento e teor de argila; e com Costa \& Carmo (1985), Santana (1986) e Correia (1993), os quais relatam que à medida que a textura do solo tende a ser mais grosseira menor é a sua CTC.

Nesse caso a CTC não tem efeito direto sobre o IS. Ela é maior nas áreas com menor IS e menor nas áreas com maior IS, porque é influenciada pelas variações dos teores de areia e argila, que por sua vez têm efeito direito sobre o IS, assim como pelos diferentes teores de alumínio encontrados, atributo que, dentro da área de estudo, predomina no complexo de troca, o que já foi explicado anteriormente.

O mapa de declividade, em graus, aponta que em praticamente toda a área experimental, 8,32ha, é possível o corte raso (classes $1,2,3$ e 4), segundo a Lei $n^{0}$ 4771/65 de 15/09/65, e que há restrição à derrubada da floresta em 0,08ha (classes 5 e 6), 
só sendo tolerada, de acordo com o artigo 10 do Código Florestal, a extração de toras, quando em regime de utilização racional, que vise a rendimentos permanentes.

Foi identificado que em apenas 1,88ha (classe 1) há possibilidade da entrada de máquinas, ou seja, em 6,52ha qualquer operação florestal exige trabalho manual. Já o mapa de declividade, em porcentagem, indica que a maior parte da área, 6,7ha (classe 4), é classificada como sendo de relevo forte ondulado, o que possibilita a ocorrência de voçorocas profundas, dificulta o controle do processo erosivo, tornando-o dispendioso e inviável. Estima-se que após 10-20 anos de cultivo, mais de 75\% do horizonte A seja removido da maior parte da área representada por esta classe.

\subsubsection{Regressão entre mapas}

No Idrisi foi realizada a análise de regressão linear simples espacial entre mapas, pixel-a-pixel, levando-se em conta a análise do valor obtido para $r^{2}$ e r (Tabela 16), e em seguida efetuou-se a regressão múltipla.

A correlação apresentada entre o mapa de IS e o de cotas $(r=-0,64)$ confirma a análise visual, anterior, do comportamento destas variáveis em seus respectivos mapas, ou seja, as baixadas apresentam mais áreas com capacidade produtiva alta do que baixa, ao contrário dos topos de morro. O mesmo pode-se dizer para cotas com $\operatorname{Arg} \mathrm{T}(\mathrm{r}=0,90)$, AreT ( $\mathrm{r}=-0,86), \mathrm{T}(\mathrm{r}=0,82), \mathrm{H}+\mathrm{Al}(\mathrm{r}=0,82), \operatorname{ArMG}(\mathrm{r}=-0,81), \mathrm{Mn}(\mathrm{r}=-0,79), \mathrm{Al}(\mathrm{r}=0,73)$, CTC (r=0,70), Umi (r=0,70), K (r=-0,69), V\% ( $r=-0,60), P(r=0,58)$, AreG ( $r=-0,57), Z n$ $(\mathrm{r}=-0,57), \mathrm{m} \%(\mathrm{r}=0,56)$ e SB $(\mathrm{r}=-0,40)$.

Estes resultados concordam com os de Santana (1986), que encontrou maiores valores de umidade e alumínio trocável nos solos do topo, valores intermediários nas encostas e valores mais baixos nas baixadas arenosas.

As associações e relações causa-efeito mais fortes com IS foram encontradas, em ordem decrescente, para cotas, AreT, ArgT, Mn, AreF, Al, CTC, ArMG e Umi. Estes resultados são semelhantes aos obtidos por meio da regressão linear simples, convencional, no SAS, na qual as associações e relações causa-efeito mais fortes com IS foram encontradas, em ordem decrescente para cotas, Al, Umi, Mn e ArgT. 
O valor do $\mathrm{r}^{2}$ obtido para a regressão entre IS e cotas explicou $42 \%$ das variações do IS, no Idrisi, e no SAS $41 \%$. No entanto, os resultados obtidos paras as demais relações não são semelhantes: Al 22,6\% no Idrisi, 14,0\% no SAS; Umid 24,8\% no Idrisi, $13,9 \%$ no SAS; ArgT $27,7 \%$ no Idrisi, $10,3 \%$ no SAS, o que pode ser justificado pela influência da componente espacial ( $\mathrm{x}, \mathrm{y})$ nas análises, uma vez que, ao contrário do SAS, as regressões no Idrisi levam em consideração a posição espacial das amostras dos atributos dentro da área estudada. Assim, há uma forte indicação que há relação no espaço entre as amostras, tanto observadas (41) como estimadas (81.919), destas variáveis e de IS. Quando esta relação é positiva, como com Mn, significa que regiões, na área de estudo, com maior capacidade produtiva são mais ricas em Mn; quando negativa, como com Al, regiões com menor capacidade produtiva são mais ricas em $\mathrm{Al}$. 
Tabela 16. Resultado da análise de regressão linear simples, pixel-a-pixel

\begin{tabular}{|c|c|c|}
\hline Variável Independente & $\vec{r}^{2}(\%)$ & $\mathbf{r}$ \\
\hline Cotas & 42,05 & $-0,64$ \\
\hline AreT & 30,89 & 0,55 \\
\hline $\operatorname{Arg} \mathrm{T}$ & 27,78 & $-0,52$ \\
\hline $\mathrm{Mn}$ & 25,78 & 0,50 \\
\hline AreF & 25,33 & 0,50 \\
\hline $\mathrm{Al}$ & 25,28 & $-0,50$ \\
\hline СTC & 24,91 & $-0,49$ \\
\hline ArMG & 24,86 & 0,49 \\
\hline Umi & 24,82 & $-0,49$ \\
\hline $\mathrm{P}$ & 21,17 & $-0,46$ \\
\hline $\mathrm{T}$ & 20,30 & $-0,45$ \\
\hline $\mathrm{H}+\mathrm{Al}$ & 19,69 & $-0,44$ \\
\hline $\mathrm{K}$ & 18,62 & 0,43 \\
\hline $\mathrm{pH}$ & 14,75 & 0,38 \\
\hline ArMF & 14,56 & 0,38 \\
\hline $\mathrm{V}$ & 11,68 & 0,34 \\
\hline $\mathrm{m}$ & 11,27 & $-0,33$ \\
\hline AreG & 08,59 & 0,29 \\
\hline Silte & 07,91 & $-0,28$ \\
\hline $\mathrm{Cu}$ & 07,71 & 0,27 \\
\hline $\mathrm{Zn}$ & 05,56 & 0,23 \\
\hline ArM & 04,50 & $-0,21$ \\
\hline $\mathrm{SB}$ & 04,10 & 0,20 \\
\hline $\mathrm{Fe}$ & 03,95 & $-0,19$ \\
\hline Decliv. (\%) & 03,41 & $-0,18$ \\
\hline SiltAr & 03,27 & $-0,18$ \\
\hline $\mathrm{S}$ & 03,16 & $-0,17$ \\
\hline Floc & 02,75 & $-0,16$ \\
\hline $\mathrm{Mg}$ & 01,77 & 0,13 \\
\hline $\mathrm{Ca}$ & 00,94 & $-0,09$ \\
\hline ArgÁ & 00,08 & 0,02 \\
\hline Face & 00,02 & 0,01 \\
\hline
\end{tabular}

Na Figura 54 é apresentado o resultado da regressão linear simples espacial entre IS (eixo y) e face de exposição (eixo x). Os valores para face de exposição foram atribuídos da seguinte forma: 1-2 S, 2-3 SO, 3-4 SE, 45 O, 5-6 NO, 6-7 N, 7-8 NE, 8-9 
E. Foram testadas todas as combinações possíveis, ou seja, NE também foi testado representando 1-2, S sendo 3-4 e assim por diante. Esta estrutura, ou ordem final, decrescendo do E para o S, foi escolhida por apresentar o maior $r$ (coeficiente de correlação linear espacial); com todas as demais foi obtido um valor de $\mathrm{r}$ menor. Portanto, das configurações testadas, mostrou ser a melhor para representar a relação positiva entre IS e face de exposição, ou seja, o acréscimo linear do valor do índice de sítio em função da face que ocupa no terreno. Nota-se que a face $\mathrm{E}$ é a mais produtiva, seguida por NE, N, NO, O, SE, SO, sendo a $\mathrm{S}$ a menos produtiva.

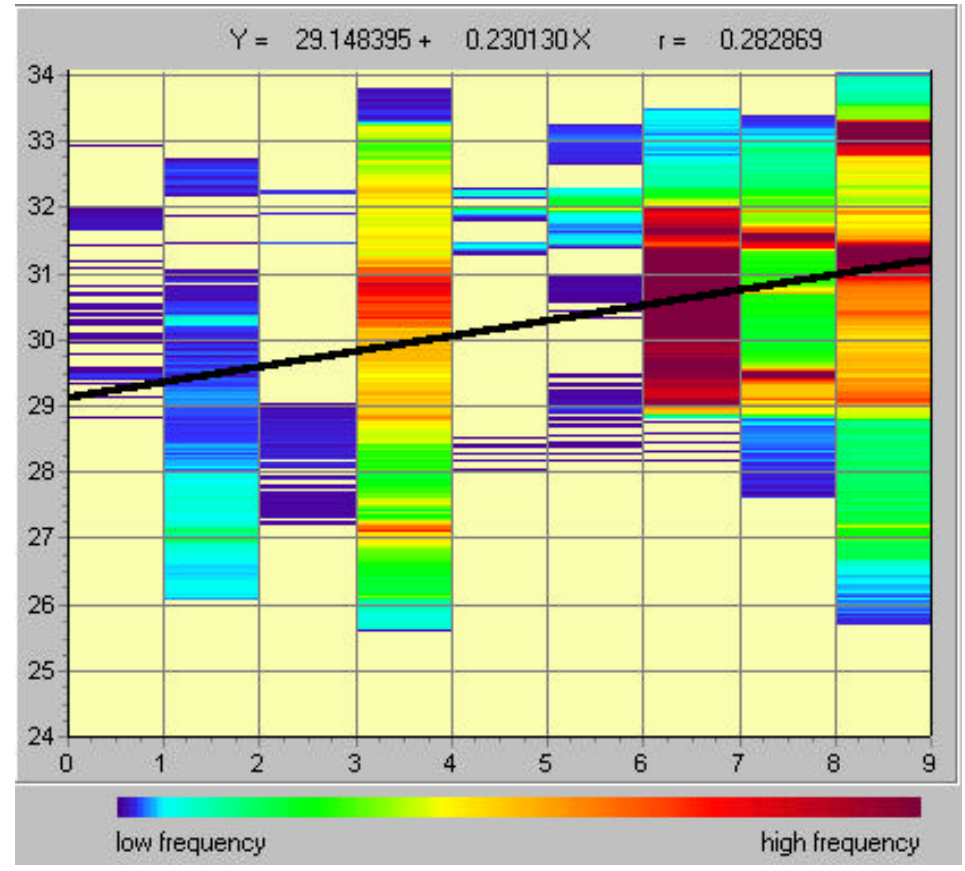

Figura 54 - Resultado da regressão linear simples espacial entre IS e face de exposição

Os resultados obtidos concordam com os de Hannah (1968b), que relata que no hemisfério Norte, a qualidade do sítio é pior na face Sul e melhor na face Norte, mas discordam quanto à conlusão que a insolação recebida pela face Sul resulta em grande evapotranspiração, causando deficiência de umidade. Acrescenta que a maior temperatura concorreu para a rápida decomposição e oxidação da matéria orgânica, com conseqüente piora das condições químicas. 
Em nosso caso a insolação é maior na face Norte, o que influencia diretamente nos resultados mais baixos obtidos para teor de umidade no solo nesta. Lopes (1973), estudando terrenos com diferentes declividades, variando de $0 \%$ a $30 \%$, com exposições $\mathrm{N}$ e $\mathrm{S}$, observou que a face $\mathrm{N}$ recebeu durante todo o ciclo da cultura de sorgo maiores quantidades de radiação solar incidente, refletindo na temperatura do solo. $\mathrm{O}$ mesmo efeito foi observado em trabalho semelhante de Galbiatti (1978), onde a rampa N recebeu maior quantidade de energia solar que a S, sendo que a com $20 \%$ de declividade foi superior àquela com $0 \%$, o que refletiu na variação de umidade no solo, ou seja, a Sul manteve-se mais úmida que a Norte.

Os resultados deste trabalho também concordam com os de Braga (1997) e Braga et al. (1999), onde as faces de exposição mais produtivas foram aquelas compreendidas entre os azimutes $315^{\circ}$ (NW) e $135^{\circ}$ (SE); com Hartung \& Lloyd (1969), que sugerem, mais criteriosamente, o intervalo entre $327,5^{\circ}$ e $112,0^{\circ}$ como o mais produtivo, entre $292,5^{\circ}$ a $337,5^{\circ}$ e $112,5^{\circ}$ a $157,5^{\circ}$ como exposições neutras e entre $157,5^{\circ}$ e $292,5^{\circ}$ como as exposições menos produtivas.

Também concorda com outros trabalhos que relatam o quadrante NE como o mais favorável ao crescimento da floresta (Trimble Jr. \& Weitzman, 1956; Doolittle, 1957; Ralston, 1964; Carmean, 1965 e 1967; Graney \& Ferguson, 1971 e 1972; Lee \& Sypolt, 1974; Geyer et al., 1980; Meeuwig \& Cooper, 1981; Meiners et al., 1984; Pregitzer \& Barnes, 1984; Callaway et al., 1987; Hix, 1988 e Archambault et al., 1990). Os terrenos voltados para face nordeste recebem radiação solar direta por toda parte da manhã, aquecendo a planta, enxugando o orvalho e favorecendo a fotossíntese.

As análises de regressão linear múltipla espacial, no Idrisi, possibilitaram selecionar dois modelos de regressão para apresentação (Tabelas 17 e 18). 
Tabela 17. Análise de variância do $1^{\circ}$ modelo de regressão múltipla espacial selecionado

\begin{tabular}{ccccccc}
\hline CV & GL & SQ & QM & Observaç. & Prob>F & F Tabela (1\%) \\
\hline (1) Modelo & 9 & $172.385,22$ & $17.238,52$ & $81.909,0$ & $31.485,28$ & 2,41 \\
Resíduo & $81.898,0$ & $44.846,03$ & 0,55 & & & \\
Total & $81.908,0$ & $217.231,25$ & & & & \\
${ }^{(1)} \mathrm{R}^{2}=0,793$ & n' variáveis $=10$ & & &
\end{tabular}

$\mathrm{IS}=272,4535+0,9314 * \mathrm{ArgT}-11,4352 * \mathrm{Ca}-1,2716^{*} \mathrm{Al}+14,6698 * \mathrm{~K}-1,1281 * \mathrm{Mg}-8,4703 * \mathrm{P}-$ $0,2443 *$ Cot- $2,7138 *$ ArMG- $0,5503 * \mathrm{Umi}+2,0986 * \mathrm{CTC}$

$\mathrm{O}$ resultado da estatística $\mathrm{F}(\mathrm{Pr}>\mathrm{F})$ muito maior que 2,41 (Tabela $\mathrm{F}$ ) permite aceitar, a $1 \%$ de significância, HA - existe relação de dependência entre as variáveis. Este valor também permitiu rejeitar H0 - não há relação de dependência entre as variáveis, concluíndo que há fortes evidências estatísticas de que existe relação causa-efeito entre a variável dependente e a(s) independente(s). Jakob et al. (1999) ressaltam que, na regressão espacial, a estatística $\mathrm{F}(\operatorname{Pr}>\mathrm{F})$ é sempre muito maior do que sua probabilidade da tabela de distribuição F (tabela), portanto, o modelo é sempre aceito. Assim, deve-se tomar muito cuidado ao analisar este resultado, uma vez que esses valores enormes de $\mathrm{F}$ são devidos à grande quantidade de resíduos criados ao interpolar os dados. No caso foram comparados 9 graus de liberdade do modelo com 81.898,0 do resíduo; já no estudo de Jakob et al. (1999) foram 6 graus de liberdade do modelo com 10.365,0 do resíduo.

O valor obtido para o $\mathrm{R}^{2}$ permite afirmar que o modelo ajustado explicou 79,3\% das variações do IS e o resíduo explicou $20,7 \%$, ou seja, as diferenças existentes entre os valores das variáveis independentes incluídas no modelo têm maior influência nas variações do IS do que o resíduo. No trabalho de Cardenas (1987) foram escolhidos modelos que apresentassem um valor do coeficiente de determinação $\left(R^{2}\right)>70 \%$. Segundo Hannah (1968a), em trabalhos de relacionamento solo-sítio, uma equação que explica $70 \%$ ou mais das variações é normalmente tida como uma relação funcional bem sucedida. De acordo com Carmean (1975), normalmente os trabalhos mais bem 
sucedidos de relação solo-sítio explicam entre $65 \%$ e $85 \%$ da variação do crescimento da floresta.

Do total de variação dos dados (SQT=217.231,25), o modelo ajustado explicou (SQM=172.385,22) enquanto que o resíduo ( $\mathrm{SQR}=44.846,03)$. A comparação entre o valor do $(\mathrm{QMM}=17.238,52)$ e do $(\mathrm{QMR}=0,55)$ comprovam que as variações do IS não são consequiência do acaso (resíduo) e podem ser explicadas pelas diferenças existentes entre os valores das variáveis independentes incluídas no modelo.

Tabela 18. Análise de variância do $2^{\circ}$ modelo de regressão múltipla espacial selecionado

\begin{tabular}{ccccccc}
\hline CV & GL & SQ & QM & Observaç. & Prob>F & F Tabela (1\%) \\
\hline (1) Modelo & 9 & $171.272,21$ & $17.127,22$ & $81.909,0$ & $30.524,42$ & 2,41 \\
Resíduo & $81.898,0$ & $45.959,05$ & 0,56 & & & \\
Total & $81.908,0$ & $217.231,25$ & & & & \\
${ }^{(1)} \mathrm{R}^{2}=0,788$ & $n^{0}$ variáveis=10 & & & &
\end{tabular}

$\mathrm{IS}=57,4641-0,0540 * \operatorname{Cot}-0,1137 * \mathrm{AreT}+0,2713 * \mathrm{ArgT}+0,0952 * \mathrm{Mn}-0,4900 * \mathrm{Al}+0,6454$

*CTC-0,0714*Umi-2,0982*P+0,8479*T-1,0563*K

Na Figura 55 são apresentados os mapas de isolinhas com os valores de IS preditos a partir dos dois modelos de regressão linear múltipla espacial ajustados e o mapa de isolinhas com os valores de IS estimados pela krigagem, apresentado anteriormente. Este procedimento possibilita a comparação visual entre esses mapas. 


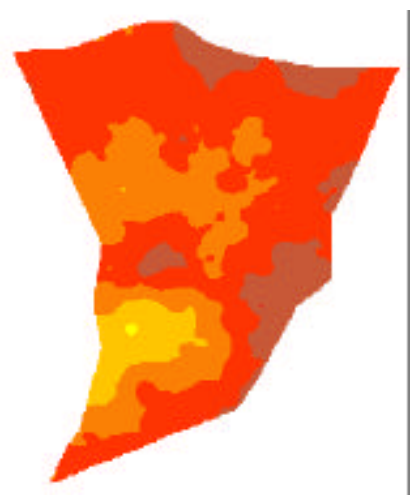

a)

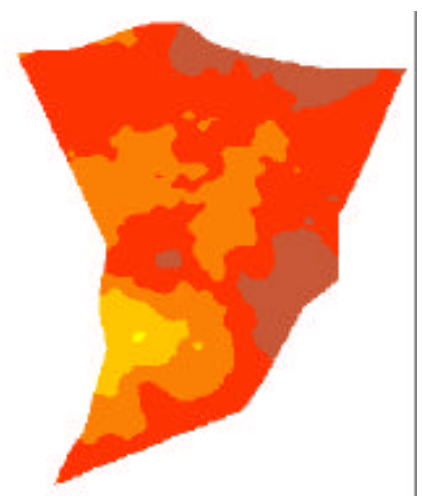

b)

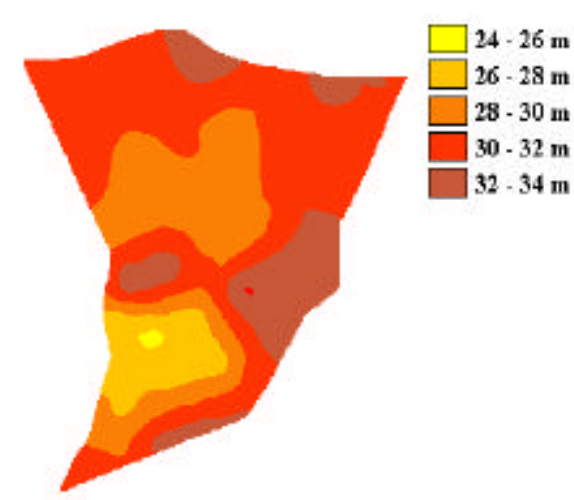

c)

Figura 55 - Mapas de isolinhas com os valores de IS preditos pelo $\mathfrak{\varrho}$ modelo (a), pelo $2^{2} \mathrm{o}$ modelo (b) e mapa de isolinhas com os valores de IS estimados (c)

A classe 1 corresponde a valores de IS no intervalo 24-26m; a 2 no intervalo 26$28 \mathrm{~m}$; a 3 no intervalo $28-30 \mathrm{~m}$; a 4 no intervalo $30-32 \mathrm{~m}$; e por fim a 5 no intervalo $32-$ $34 \mathrm{~m}$. Nota-se, com a análise visual da distribuição espacial dos valores preditos para IS na área experimental, a boa qualidade das duas equações ajustadas. 


\section{CONCLUSÕES}

Todas as variáveis apresentaram dependência espacial, exceto B e MO, sendo que o modelo esférico apresentou o melhor ajuste para os semivariogramas.

Os métodos estatísticos clássicos, geoestatísticos e de geoprocessamento utilizados, permitiram concluir que os atributos físicos do solo, mais especificamente a estrutura e a textura, e a fisiografia, mostraram ser mais importantes na determinação do potencial produtivo (IS) do que os atributos químicos. Também possibilitaram identificar os atributos que influenciam no potencial produtivo do talhão, com destaque para: cotas e alumínio, de forma indireta; e umidade, argila total, areia total, areia muito grossa, manganês e soma de bases trocáveis (principalmente o cátion potássio), de forma direta.

Com o emprego da análise geoestatística, combinada a técnicas de geoprocessamento, foi possível mapear a variabilidade espacial de atributos do solo e do relevo e do potencial produtivo do talhão, assim como relacionar a variabilidade dos atributos do solo e do relevo entre si e entre eles e o potencial produtivo do talhão, com destaque para a relação entre a distribuição de cotas, areia total, argila total e alumínio com a do índice de sítio; e entre a de cotas, areia total, argila total, areia muito grossa e umidade.

No geral, as áreas de maior potencial produtivo apresentaram menores teores de alumínio, argila total e umidade; maiores teores de manganês, soma de bases trocáveis, areia total e areia muito grossa; além de ocuparem posição menos elevada no relevo, ou seja, cotas mais baixas. Este cenário determina maior porosidade e permeabilidade ao solo, beneficiando a aeração, penetração e crescimento do sistema radicular, favorecendo a absorção de nutrientes e água pelas raízes, uma vez que explora maior volume de solo, atingindo reservas hídricas e de nutrientes em horizontes mais profundos; assim como as 
condições de drenagem do solo, facilitando a penetração das águas de chuvas pouco intensas.

Os resultados mostraram que o melhor modelo de regressão linear múltipla ajustado explicou $65 \%$ das variações do IS, enquanto que o melhor modelo para a regressão espacial explicou $79 \%$ das variações do IS. 
ANEXOS 
Anexo A - Resultados das análises químicas para os macronutrientes do solo, na profundidade de $0-20 \mathrm{~cm}$

\begin{tabular}{|c|c|c|c|c|c|c|c|c|c|c|c|c|c|c|}
\hline Amostra & pH & MO & $\mathbf{P}$ & $\mathbf{S}$ & $\bar{K}$ & $\mathbf{C a}$ & $\mathrm{Mg}$ & $\overline{A l}$ & $\mathrm{H}+\mathrm{Al}$ & $\overline{\text { SB }}$ & $\mathbf{T}$ & CTC & $\mathbf{V}$ & $\mathbf{m}$ \\
\hline $\mathbf{n}^{0}$ & $\mathrm{CaCl}_{2}$ & $\left(\mathrm{~g} \mathrm{dm}^{-3}\right)$ & \multicolumn{2}{|c|}{$\left(\mathrm{mg} \mathrm{dm}^{-3}\right)$} & 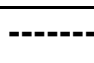 & 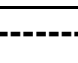 & $-\cdots$ & $(\mathbf{m r}$ & $\left(\mathbf{c d m}^{-3}\right)$ & --'-- & -----י & ------- & $\cdots$ & ) --- \\
\hline 1 & 3,7 & 31 & 6 & 14 & 0,2 & 1 & 2 & 18 & 98 & 3,2 & 101,2 & 21,2 & 3 & 85 \\
\hline 2 & 3,8 & 32 & 5 & 17 & 0,5 & 2 & 2 & 19 & 109 & 4,5 & 113,5 & 23,5 & 4 & 81 \\
\hline 3 & 3,7 & 32 & 5 & 13 & 0,8 & 2 & 2 & 20 & 98 & 4,8 & 102,8 & 24,8 & 5 & 81 \\
\hline 4 & 3,8 & 24 & 6 & 18 & 0,6 & 1 & 1 & 18 & 88 & 2,6 & 90,6 & 20,6 & 3 & 87 \\
\hline 5 & 3,7 & 29 & 5 & 21 & 0,7 & 1 & 1 & 17 & 109 & 2,7 & 111,7 & 19,7 & 2 & 86 \\
\hline 6 & 3,6 & 31 & 4 & 24 & 0,7 & 1 & 1 & 22 & 135 & 2,7 & 137,7 & 24,7 & 2 & 89 \\
\hline 7 & 3,6 & 31 & 5 & 14 & 0,6 & 1 & 1 & 23 & 135 & 2,6 & 137,6 & 25,6 & 2 & 90 \\
\hline 8 & 3,6 & 38 & 6 & 21 & 0,1 & 2 & 2 & 24 & 150 & 4,1 & 154,1 & 28,1 & 3 & 85 \\
\hline 9 & 3,5 & 44 & 7 & 16 & 0,1 & 1 & 2 & 32 & 166 & 3,1 & 169,1 & 35,1 & 2 & 91 \\
\hline 10 & 3,7 & 31 & 4 & 16 & 0,1 & 1 & 1 & 19 & 109 & 2,1 & 111,1 & 21,1 & 2 & 90 \\
\hline 11 & 3,5 & 35 & 5 & 16 & 0,2 & 2 & 1 & 26 & 150 & 3,2 & 153,2 & 29,2 & 2 & 89 \\
\hline 12 & 3,7 & 36 & 4 & 25 & 0,1 & 1 & 1 & 28 & 150 & 2,1 & 152,1 & 30,1 & 1 & 93 \\
\hline 13 & 3,5 & 36 & 5 & 18 & 0,1 & 1 & 1 & 24 & 150 & 2,1 & 152,1 & 26,1 & 1 & 92 \\
\hline 14 & 3,3 & 40 & 6 & 14 & 0,1 & 1 & 1 & 30 & 205 & 2,1 & 207,1 & 32,1 & 1 & 93 \\
\hline 15 & 3,7 & 28 & 3 & 21 & 0,1 & 1 & 1 & 19 & 109 & 2,1 & 111,1 & 21,1 & 2 & 90 \\
\hline 16 & 3,5 & 28 & 4 & 11 & 0,3 & 1 & 1 & 20 & 109 & 2,3 & 111,3 & 22,3 & 2 & 90 \\
\hline 17 & 3,7 & 36 & 5 & 11 & 0,4 & 1 & 1 & 26 & 150 & 2,4 & 152,4 & 28,4 & 2 & 92 \\
\hline 18 & 3,5 & 29 & 8 & 11 & 0,4 & 1 & 2 & 21 & 135 & 3,4 & 138,4 & 24,4 & 2 & 86 \\
\hline 19 & 3,7 & 29 & 6 & 10 & 0,5 & 1 & 2 & 19 & 109 & 3,5 & 112,5 & 22,5 & 3 & 84 \\
\hline 20 & 3,7 & 28 & 4 & 21 & 0,1 & 1 & 1 & 18 & 98 & 2,1 & 100,1 & 20,1 & 2 & 90 \\
\hline
\end{tabular}


Anexo A - Resultados das análises químicas para os macronutrientes do solo, na profundidade de 0-20 cm

\begin{tabular}{ccccccccccccccc}
\hline Amostra & $\mathbf{p H}$ & $\mathbf{M O}$ & $\mathbf{P}$ & $\mathbf{S}$ & $\mathbf{K}$ & $\mathbf{C a}$ & $\mathbf{M g}$ & $\mathbf{A l}$ & $\mathbf{H + A l}$ & $\mathbf{S B}$ & $\mathbf{T}$ & $\mathbf{C T C}$ & $\mathbf{V}$ & $\mathbf{m}$ \\
\hline 21 & 3,9 & 23 & 5 & 11 & 0,4 & 1 & 2 & 16 & 88 & 3,4 & 91,4 & 19,4 & 4 & 82 \\
22 & 3,9 & 28 & 3 & 18 & 0,9 & 1 & 2 & 17 & 88 & 3,9 & 91,9 & 20,9 & 4 & 81 \\
23 & 3,8 & 31 & 5 & 9 & 0,9 & 2 & 2 & 21 & 98 & 4,9 & 102,9 & 25,9 & 5 & 81 \\
24 & 3,8 & 31 & 4 & 18 & 0,4 & 1 & 1 & 18 & 98 & 2,4 & 100,4 & 20,4 & 2 & 88 \\
25 & 3,7 & 25 & 3 & 11 & 0,9 & 1 & 1 & 18 & 88 & 2,9 & 90,9 & 20,9 & 3 & 86 \\
26 & 3,8 & 28 & 4 & 9 & 1,0 & 1 & 2 & 18 & 88 & 4,0 & 92,0 & 22 & 4 & 82 \\
27 & 3,6 & 33 & 5 & 18 & 0,1 & 1 & 1 & 20 & 135 & 2,1 & 137,1 & 22,1 & 2 & 90 \\
28 & 3,7 & 31 & 5 & 18 & 0,4 & 1 & 1 & 20 & 121 & 2,4 & 123,4 & 22,4 & 2 & 89 \\
29 & 3,6 & 30 & 3 & 21 & 0,8 & 1 & 1 & 22 & 121 & 2,8 & 123,8 & 24,8 & 2 & 89 \\
30 & 3,7 & 29 & 3 & 13 & 0,7 & 1 & 1 & 20 & 109 & 2,7 & 111,7 & 22,7 & 2 & 88 \\
31 & 3,8 & 29 & 3 & 25 & 0,7 & 1 & 1 & 14 & 80 & 2,7 & 82,7 & 16,7 & 3 & 84 \\
32 & 3,6 & 38 & 2 & 23 & 0,8 & 1 & 1 & 20 & 150 & 2,8 & 152,8 & 22,8 & 2 & 88 \\
33 & 3,8 & 26 & 3 & 18 & 0,2 & 1 & 1 & 15 & 88 & 2,2 & 90,2 & 17,2 & 2 & 87 \\
34 & 3,9 & 28 & 2 & 11 & 0,6 & 1 & 1 & 15 & 88 & 2,6 & 90,6 & 17,6 & 3 & 85 \\
35 & 3,6 & 29 & 4 & 14 & 0,2 & 1 & 1 & 18 & 109 & 2,2 & 111,2 & 20,2 & 2 & 89 \\
36 & 3,5 & 34 & 5 & 21 & 0,2 & 1 & 1 & 23 & 150 & 2,2 & 152,2 & 25,2 & 1 & 91 \\
37 & 3,8 & 30 & 5 & 14 & 0,7 & 1 & 1 & 18 & 98 & 2,7 & 100,7 & 20,7 & 3 & 87 \\
38 & 3,7 & 32 & 4 & 11 & 0,6 & 1 & 1 & 23 & 135 & 2,6 & 137,6 & 25,6 & 2 & 90 \\
39 & 3,7 & 26 & 4 & 11 & 0,2 & 1 & 1 & 20 & 98 & 2,2 & 100,2 & 22,2 & 2 & 90 \\
40 & 3,6 & 32 & 5 & 11 & 0,4 & 1 & 1 & 20 & 109 & 2,4 & 111,4 & 22,4 & 2 & 89 \\
41 & 3,7 & 32 & 4 & 18 & 0,4 & 18 & 2 & 20 & 121 & 20,4 & 141,4 & 40,4 & 14 & 50 \\
\hline
\end{tabular}


Anexo B - Resultados das análises físicas do solo, na profundidade de 0-20 cm

\begin{tabular}{|c|c|c|c|c|c|c|c|c|c|c|c|}
\hline \multirow{2}{*}{$\begin{array}{c}\text { Amostra } \\
\text { no }^{0}\end{array}$} & \multicolumn{6}{|c|}{ Areia (\%) } & \multirow{2}{*}{$\begin{array}{l}\text { Silte } \\
(\%)\end{array}$} & \multicolumn{2}{|c|}{ Argila (\%) } & \multirow{2}{*}{$\begin{array}{c}\text { Floculação } \\
(\%)\end{array}$} & \multirow{2}{*}{$\begin{array}{c}\text { Relação } \\
\text { Silte/Argila }\end{array}$} \\
\hline & MG & $\mathbf{G}$ & $\mathbf{M}$ & $\mathbf{F}$ & MF & Total & & Total & Água & & \\
\hline 1 & 4 & 17 & 17 & 16 & 1 & 55 & 8 & 37 & 16 & 56 & 0,216 \\
\hline 2 & 3 & 16 & 18 & 15 & 1 & 53 & 8 & 39 & 16 & 58 & 0,205 \\
\hline 3 & 3 & 17 & 16 & 13 & 2 & 51 & 10 & 39 & 16 & 58 & 0,256 \\
\hline 4 & 3 & 13 & 22 & 16 & 1 & 55 & 8 & 37 & 18 & 50 & 0,216 \\
\hline 5 & 1 & 11 & 14 & 14 & 1 & 41 & 8 & 51 & 14 & 72 & 0,156 \\
\hline 6 & 2 & 14 & 16 & 13 & 1 & 46 & 2 & 52 & 19 & 64 & 0,038 \\
\hline 7 & 1 & 10 & 15 & 16 & 1 & 43 & 6 & 51 & 17 & 67 & 0,117 \\
\hline 8 & 2 & 10 & 15 & 11 & 1 & 39 & 11 & 50 & 15 & 71 & 0,220 \\
\hline 9 & 2 & 13 & 13 & 10 & 1 & 39 & 10 & 51 & 23 & 54 & 0,196 \\
\hline 10 & 1 & 18 & 17 & 12 & 1 & 49 & 11 & 40 & 19 & 53 & 0,275 \\
\hline 11 & 2 & 17 & 16 & 13 & 1 & 49 & 8 & 43 & 26 & 40 & 0,186 \\
\hline 12 & 2 & 17 & 14 & 13 & 1 & 47 & 7 & 46 & 21 & 55 & 0,152 \\
\hline 13 & 1 & 15 & 19 & 14 & 1 & 50 & 4 & 46 & 25 & 45 & 0,086 \\
\hline 14 & 2 & 14 & 14 & 11 & 1 & 42 & 9 & 49 & 26 & 48 & 0,183 \\
\hline 15 & 3 & 15 & 13 & 11 & 2 & 44 & 11 & 45 & 36 & 19 & 0,244 \\
\hline 16 & 1 & 15 & 12 & 11 & 2 & 41 & 15 & 44 & 21 & 52 & 0,340 \\
\hline 17 & 2 & 20 & 14 & 12 & 2 & 50 & 8 & 42 & 25 & 40 & 0,190 \\
\hline 18 & 2 & 17 & 13 & 11 & 3 & 46 & 8 & 46 & 23 & 50 & 0,173 \\
\hline 19 & 4 & 22 & 12 & 13 & 2 & 53 & 6 & 41 & 21 & 50 & 0,146 \\
\hline 20 & 6 & 15 & 13 & 17 & 2 & 53 & 6 & 41 & 22 & 45 & 0,146 \\
\hline
\end{tabular}


Anexo B - Resultados das análises físicas do solo, na profundidade de 0-20 cm

\begin{tabular}{|c|c|c|c|c|c|c|c|c|c|c|c|}
\hline \multirow{2}{*}{$\begin{array}{c}\text { Amostra } \\
\text { n}^{0}\end{array}$} & \multicolumn{6}{|c|}{ Areia (\%) } & \multirow{2}{*}{$\begin{array}{l}\text { Silte } \\
(\%)\end{array}$} & \multicolumn{2}{|c|}{ Argila (\%) } & \multirow{2}{*}{$\begin{array}{c}\text { Floculação } \\
(\%)\end{array}$} & \multirow{2}{*}{$\begin{array}{c}\text { Relação } \\
\text { Silte/Argila }\end{array}$} \\
\hline & MG & $\mathbf{G}$ & $\mathbf{M}$ & $\mathbf{F}$ & MF & Total & & Total & Água & & \\
\hline 21 & 7 & 18 & 13 & 14 & 3 & 55 & 6 & 39 & 31 & 21 & 0,153 \\
\hline 22 & 5 & 14 & 12 & 18 & 4 & 53 & 8 & 39 & 25 & 37 & 0,205 \\
\hline 23 & 7 & 17 & 14 & 18 & 3 & 59 & 6 & 35 & 25 & 29 & 0,171 \\
\hline 24 & 8 & 16 & 12 & 15 & 2 & 53 & 4 & 43 & 31 & 29 & 0,093 \\
\hline 25 & 6 & 18 & 14 & 17 & 4 & 59 & 4 & 37 & 22 & 39 & 0,108 \\
\hline 26 & 9 & 19 & 13 & 15 & 3 & 59 & 4 & 37 & 29 & 22 & 0,108 \\
\hline 27 & 4 & 14 & 14 & 15 & 4 & 51 & 4 & 45 & 27 & 41 & 0,088 \\
\hline 28 & 6 & 17 & 15 & 17 & 2 & 57 & 4 & 39 & 20 & 47 & 0,102 \\
\hline 29 & 9 & 19 & 13 & 13 & 3 & 57 & 6 & 37 & 24 & 33 & 0,162 \\
\hline 30 & 7 & 16 & 13 & 16 & 3 & 55 & 6 & 39 & 27 & 32 & 0,153 \\
\hline 31 & 3 & 17 & 13 & 13 & 2 & 48 & 9 & 43 & 29 & 33 & 0,209 \\
\hline 32 & 3 & 16 & 14 & 17 & 3 & 53 & 6 & 41 & 14 & 65 & 0,146 \\
\hline 33 & 7 & 14 & 15 & 21 & 4 & 61 & 4 & 35 & 16 & 53 & 0,114 \\
\hline 34 & 9 & 19 & 14 & 17 & 4 & 63 & 4 & 33 & 16 & 50 & 0,121 \\
\hline 35 & 5 & 16 & 14 & 14 & 2 & 51 & 6 & 43 & 33 & 24 & 0,139 \\
\hline 36 & 5 & 22 & 14 & 16 & 2 & 59 & 2 & 39 & 25 & 37 & 0,051 \\
\hline 37 & 3 & 16 & 16 & 19 & 3 & 57 & 4 & 39 & 19 & 53 & 0,102 \\
\hline 38 & 3 & 19 & 14 & 16 & 3 & 55 & 4 & 41 & 25 & 40 & 0,097 \\
\hline 39 & 2 & 19 & 16 & 15 & 3 & 55 & 4 & 41 & 31 & 25 & 0,097 \\
\hline 40 & 8 & 22 & 15 & 14 & 2 & 61 & 2 & 37 & 25 & 33 & 0,054 \\
\hline 41 & 3 & 16 & 14 & 15 & 3 & 51 & 4 & 45 & 25 & 45 & 0,088 \\
\hline
\end{tabular}


Anexo C - Valores das medições para atributos da planta, do relevo e resultados das análises químicas para os micronu-

trientes e umidade do solo, na profundidade de $0-20 \mathrm{~cm}$

\begin{tabular}{|c|c|c|c|c|c|c|c|c|c|c|c|c|c|}
\hline Amostra & Cota & H média & IS & DAP & B & $\mathbf{C u}$ & $\mathbf{F e}$ & Mn & $\mathbf{Z n}$ & Umidade & Declivid. & Declivid. & ace de Exp. \\
\hline $\mathrm{n}^{\mathbf{0}}$ & - & (metros) & ) ----------' & (cm) & $-\cdots-$ & $\cdots(n$ & $\mathrm{ng} \mathrm{dm}$ & $\left.{ }^{-3}\right)---$ & ---- & $(\%)$ & (graus) & $(\%)$ & (graus) \\
\hline 1 & 947,37 & 29,66 & 30,733 & 20,46 & 0,51 & 1,0 & 102 & 2,6 & 0,8 & 16,2 & 14,66 & 26,17 & 355,05 \\
\hline 2 & 964,249 & 30,36 & 31,4583 & 21,5 & 0,43 & 1,4 & 129 & 0,8 & 0,5 & 15,94 & 20,27 & 36,94 & 344,57 \\
\hline 3 & 943,626 & 29,7 & 30,7744 & 20,12 & 0,60 & 0,9 & 99 & 2,0 & 0,6 & 15,77 & 13,73 & 24,43 & 355,52 \\
\hline 4 & 961,764 & 29,46 & 30,5257 & 20,8 & 0,68 & 1,3 & 112 & 1,6 & 0,8 & 16,16 & 20,39 & 37,17 & 352,09 \\
\hline 5 & 982,711 & 29,86 & 30,9402 & 22,1 & 0,58 & 0,5 & 124 & 0,6 & 0,3 & 21,34 & 18,72 & 33,89 & 342,08 \\
\hline 6 & 978,539 & 28 & 29,0129 & 18,1 & 0,51 & 0,7 & 197 & 0,6 & 0,3 & 23,77 & 18,68 & 33,8 & 3,23 \\
\hline 7 & 995,959 & 27,8 & 28,8057 & 19,8 & 0,63 & $-1,0$ & 166 & 0,4 & 0,3 & 24,06 & 7,89 & 13,86 & 0,61 \\
\hline 8 & 989,241 & 27,92 & 28,93 & 19,5 & 0,69 & 0,1 & 168 & 0,4 & 0,3 & 22,13 & 11,76 & 20,83 & 71,87 \\
\hline 9 & 994,842 & 32,04 & 33,1991 & 19,7 & 0,45 & $-1,0$ & 153 & 0,2 & 0,4 & 24,16 & 14,02 & 24,97 & 73,64 \\
\hline 10 & 976,04 & 32,24 & 33,4063 & 18,9 & 0,51 & 0,3 & 205 & 0,4 & 0,3 & 21,32 & 17,36 & 31,27 & 90 \\
\hline 11 & 989,951 & 24,58 & 25,4692 & 18,2 & 0,69 & 0,1 & 312 & 0,4 & 0,4 & 26,66 & 15,5 & 27,73 & 131,24 \\
\hline 12 & 978,061 & 26,32 & 27,2721 & 16,2 & 0,53 & $-1,0$ & 100 & 0,4 & 0,3 & 22,76 & 18,2 & 32,88 & 77,74 \\
\hline 13 & 974,552 & 26,82 & 27,7902 & 18 & 0,68 & 0,2 & 236 & 0,6 & 0,4 & 23,77 & 21,13 & 38,65 & 178,06 \\
\hline 14 & 977,496 & 26,56 & 27,5208 & 19,5 & 0,72 & 0,2 & 291 & 0,2 & 0,3 & 30,09 & 18,44 & 33,35 & 122,52 \\
\hline 15 & 969,011 & 26,22 & 27,1685 & 17,5 & 0,63 & 0,2 & 200 & 0,2 & 0,3 & 23,77 & 18,78 & 34 & 110,58 \\
\hline 16 & 958,356 & 31,7 & 32,8468 & 19 & 0,58 & 0,3 & 247 & 2,2 & 0,3 & 24,43 & 13,66 & 24,31 & 133,29 \\
\hline 17 & 955,873 & 31,16 & 32,2872 & 21,8 & 0,55 & 0,3 & 323 & 1,2 & 0,4 & 22,63 & 12,31 & 21,82 & 131,33 \\
\hline 18 & 965,747 & 31,48 & 32,6188 & 20,4 & 0,77 & 0,6 & 208 & 1,4 & 0,4 & 25,39 & 12,25 & 21,71 & 115,18 \\
\hline 19 & 968,221 & 28,94 & 29,9869 & 19,16 & 0,59 & 0,7 & 203 & 6,0 & 0,9 & 22,67 & 12,47 & 22,11 & 128,98 \\
\hline 20 & 969,405 & 29,32 & 30,3807 & 21 & 0,58 & 1,5 & 134 & 0,8 & 0,4 & 17,92 & 18,36 & 33,2 & 12,2 \\
\hline
\end{tabular}


Anexo C - Valores das medições para atributos da planta, do relevo e resultados das análises químicas para os micronu-

trientes e umidade do solo, na profundidade de 0-20 cm

\begin{tabular}{|c|c|c|c|c|c|c|c|c|c|c|c|c|c|}
\hline Amostra & Cota & H média & IS & DAP & B & $\mathrm{Cu}$ & $\mathbf{F e}$ & Mn & $\mathbf{Z n}$ & Umidade & Declivid. & Declivid. & $\overline{\text { Face de Exp. }}$ \\
\hline 21 & 961,432 & 27,84 & 28,8471 & 19,8 & 0,65 & 1,4 & 80 & 0,8 & 0,5 & 18,14 & 19,03 & 34,5 & 14,81 \\
\hline 22 & 950,436 & 30,34 & 31,4376 & 22,7 & 0,53 & 1,0 & 63 & 1,8 & 0,5 & 18,2 & 16,42 & 29,47 & 22,5 \\
\hline 23 & 941,364 & 31,22 & 32,3494 & 23,4 & 0,60 & 0,6 & 117 & 3,0 & 0,7 & 15,14 & 6,69 & 11,73 & 355,58 \\
\hline 24 & 953,529 & 29,76 & 30,8366 & 20,9 & 0,59 & 1,2 & 97 & 1,0 & 0,5 & 16,94 & 19,74 & 35,89 & 9,81 \\
\hline 25 & 940,237 & 32,36 & 33,5306 & 20,4 & 0,53 & 1,3 & 99 & 4,4 & 0,7 & 16,86 & 12,97 & 23,03 & 10,4 \\
\hline 26 & 942,244 & 30 & 31,0853 & 21,2 & 0,53 & 0,6 & 94 & 0,8 & 0,5 & 17,3 & 10,85 & 19,17 & 348,53 \\
\hline 27 & 979,147 & 28,16 & 29,1787 & 19,4 & 0,71 & 0,4 & 224 & 0,6 & 0,4 & 18,46 & 9,69 & 17,08 & 56,44 \\
\hline 28 & 969,557 & 28,78 & 29,8211 & 20,5 & 0,66 & 1,2 & 171 & 1,0 & 0,3 & 19,01 & 12,17 & 21,58 & 52,59 \\
\hline 29 & 959,509 & 30,36 & 31,4583 & 23,1 & 0,66 & 0,6 & 134 & 1,2 & 0,4 & 18,25 & 13,45 & 23,92 & 60,42 \\
\hline 30 & 949,388 & 30,5 & 31,6033 & 22,2 & 0,63 & 0,7 & 175 & 0,6 & 0,4 & 19,62 & 7,51 & 13,2 & 39,08 \\
\hline 31 & 970,54 & 27,06 & 28,0389 & 17,7 & 0,51 & 0,2 & 70 & 0,4 & 0,2 & 21,83 & 14,18 & 25,28 & 129,17 \\
\hline 32 & 967,716 & 28,46 & 29,4896 & 19,2 & 0,72 & 0,2 & 380 & 1,0 & 0,4 & 18,46 & 16,55 & 29,73 & 130,06 \\
\hline 33 & 957,805 & 30,76 & 31,8728 & 21,8 & 0,63 & 0,3 & 169 & 1,8 & 0,2 & 16,57 & 19,63 & 35,67 & 105,43 \\
\hline 34 & 943,361 & 29,1 & 30,1527 & 17,8 & 0,65 & 0,4 & 155 & 2,0 & 0,5 & 19,23 & 13,32 & 23,67 & 113,24 \\
\hline 35 & 960,963 & 32,96 & 34,1523 & 23,6 & 0,77 & 0,6 & 96 & 0,6 & 0,2 & 22,36 & 16,07 & 28,81 & 93 \\
\hline 36 & 951,641 & 31,9 & 33,054 & 21,3 & 0,43 & 0,4 & 304 & 1,2 & 0,4 & 19,83 & 15,54 & 27,82 & 124,02 \\
\hline 37 & 946,141 & 32,24 & 33,4063 & 21,4 & 0,41 & 0,3 & 255 & 1,8 & 0,4 & 18,97 & 12,66 & 22,46 & 114,14 \\
\hline 38 & 998,222 & 26,3 & 27,2514 & 19,5 & 0,34 & $-1,0$ & 190 & 0,6 & 0,2 & 20,61 & 6,99 & 12,26 & 140,36 \\
\hline 39 & 966,781 & 27,38 & 28,3705 & 15,6 & 0,48 & 0,2 & 245 & 1,2 & 0,3 & 24,44 & 16,1 & 28,88 & 132,16 \\
\hline 40 & 954,57 & 31,22 & 32,3494 & 20,9 & 0,50 & 0,4 & 231 & 1,4 & 0,4 & 20,31 & 14,78 & 26,38 & 92,07 \\
\hline 41 & 971,988 & 29,98 & 31,0645 & 20 & 0,47 & 0,6 & 175 & 3,6 & 0,7 & 20,89 & 9,96 & 17,57 & 140,5 \\
\hline
\end{tabular}




\section{REFERÊNCIAS BIBLIOGRÁFICAS}

ALBUQUERQUE, J.A.; REINERT, D.J.; FIORIN, J.E. Variabilidade de solos e planta em podzólico vermelho-amarelo. Revista Brasileira de Ciência do Solo, v.20, n.1, p.151-157, 1996.

ALEMDAG, I.S. National site-index and height-growth curves for white spruce growing in natural stands in Canada. Canadian Journal of Forest Research, v.21, n.10, p.1466-1474, 1991.

ALMEIDA, C.F.P.; RIBEIRO JÚNIOR, P.J. Estimativa da distribuição espacial de retenção de água em um solo utilizando krigagem indicatriz Curitiba: UFPR, Departamento de Estatística, 1996. 37p.

ALMEIDA, F.F.M. Fundamentos geológicos do relevo paulista. Boletim do Instituto de Geografia e Geologia, v.41, p.169-263, 1964.

ALVARENGA, R.N. Potencial econômico de eucalipto segundo as regiões. In: CONFERÊNCIA MUNDIAL DE EUCALIPTO, 2., São Paulo, 1961. Anais. São Paulo: FAO, 1961. p.161-164.

ALVAREZ, V.H.; MELLO, J.W.V. de; DIAS, L.E. Módulo 4: acidez e calagem do solo. In: ASSOCIAÇÃO BRASILEIRA DE EDUCAÇÃO AGRÍCOLA SUPERIOR. Curso de fertilidade e manejo do solo. Brasília: ABEAS, 1996. 68p.

AMARAL, G. Características químicas e físicas de diferentes classes de solos da zona metalúrgica mineira e produtividade de eucalipto. Viçosa, 2000. 98p. Dissertação (Mestrado) - Universidade Federal de Viçosa.

ARCHAMBAULT, L.; BARNES, B.V.; WITTER, J.A. Landscape ecosystems of disturbed oak forests of southeastern Michigan, USA. Canadian Journal of Forest Research, v.20, p.1570-1582, 1990. 
ASSIS, F.N.; ARRUDA, H.V.; PEREIRA, A.R. Aplicações da estatística à climatologia. Pelotas: Universidade Federal de Pelotas, 1996. 161p.

ASSMANN, E. Waldertragskunde. Munchen: BLV Verlagsgesselschaft, 1961. 425p.

AUTODESK. AutoCAD, release 14: software de desenho digital (software). USA, 1998.

AWE, J.O.; SHEPHERD, K.R.; FLORENCE, R.G. Root development in provenances of Eucalyptus camaldulensis Dehn. Australian Forest, v.85, p.201-209, 1976.

BAIO, F.H.R. Aplicação localizada de defensivos baseada na variabilidade espacial das plantas daninhas, 2001. 113p. Dissertação (Mestrado) - Escola Superior de Agricultura "Luiz de Queiroz", Universidade de São Paulo.

BALASTREIRE, L.A. A experiência com pesquisa em agricultura de precisão na ESALQ/USP (compact disc). In: CONGRESSO E FEIRA PARA USUÁRIOS DE GEOPROCESSAMENTO DA AMÉRICA LATINA - GIS BRASIL 98, 4., Curitiba, 1998. Anais. Curitiba, 1998.

BALASTREIRE, L.A.; ELIAS, A.I.; AMARAL, J.R. do. A agricultura de precisão: mapeamento da produtividade da cultura de milho. Engenharia Rural, v.8, n.1, p.97-111, jul. 1997.

BALL, S.T.; MULLA, D.J.; KONZAK, C.F. Spatial heterogeneity affects variety trial interpretation. Crop Science, v.33, p.931-935, 1993.

BARNES, R.D.; RALSTON, C.W. Soil factors related to growth and yield of slash pine plantations. Florida: Florida Agriculture Experiment Station, 1955. 23p. (Bulletin, 559).

BARROS, N.F. Contribuição ao relacionamento de características pedológicas e topográficas com altura de Eucalyptus alba, na região de Santa Bárbara, MG. Viçosa, 1974. 89p. Dissertação (Mestrado) - Universidade Federal de Viçosa.

BARROS, N.F. de; NOVAIS, R.F. de; NEVES, J.C.L. Fertilização e correção do solo para plantio de eucalipto. In: BARROS, N.F.; NOVAIS, R.F. Relação soloeucalipto. Viçosa: Editora Folha de Viçosa, 1990b. p.127-186. 
BARROS, N.F. de; NOVAIS, R.F. de; CARDOSO, J.R.; MACEDO, P.R.O. Algumas relações solo-espécies de eucalipto em suas condições naturais. In: BARROS, N.F.; NOVAIS, R.F. Relação solo-eucalipto. Viçosa: Editora Folha de Viçosa, 1990a. p.1-24.

BARROS, N.F.; NOVAIS, R.F.; CARMO, D.N.; NEVES, J.C.L. Classificação nutricional de sítios florestais - Descrição de uma metodologia. Revista Árvore, v.10, n.1, p.112-120. 1986.

BARUQUI, A.M. Comentários sobre a descrição e resultados analíticos de um perfil de solo. Informe Agropecuário, v.9, n.105, p.33-44, 1983.

BECKER, G. Precision Forestry in Central Europe: new perspectives for a classical management concept. In: INTERNATIONAL PRECISION FORESTRY COOPERATIVE SYMPOSIUM, 1., Seattle, 2001. Proceedings. Seattle: University of WashingtonCollege of Forest Resources, 2001. p.7-9.

BEIGUELMAN, B. Curso prático de bioestatística. 3.ed. Ribeirão Preto: Sociedade Brasileira de Genética, 1994. 244p.

BELLOTE, A.F.J. Concentração, acumulação e deposição de nutrientes pelo Eucalyptus grandis (Hill ex Maiden) em função da idade. Piracicaba, 1979. 129p. Dissertação (Mestrado) - Escola Superior de Agricultura "Luiz de Queiroz", Universidade de São Paulo.

BELTRAME, L.F.S.; GOMES, L.A.P.; TAYLOR, J.C. Estrutura e compactação do solo. Revista Brasileira de Ciência do Solo, v.5, n.3, p.145-149, 1981.

BHATTI, A.U.; MULLA, D.J.; KOEHLER, F.E.; GURMUNI, A.H. Identifying and removing spatial correlation from yield experiments. Soil Science Society of America Journal, v.55, n. 6, p.1523-1528, 1991.

BIERWAGEN, R.; ONUKI, M.; BERGAMASCHI, R. Integração SIG-SAS - cadastro florestal para implantação de um sistema de informações florestais (compact disc). In: SEMINÁRIO DE ATUALIZAÇÃO EM SENSORIAMENTO REMOTO E SISTEMAS DE INFORMAÇÕES GEOGRÁFICAS APLICADOS A ENGENHARIA FLORESTAL, 4., Curitiba, 2000. Anais. Curitiba, 2000. 
BILLET, M.F.; FITZPATRICK, E.A.; CRESSER, M.S. Long-term changes in the acidity of forest soils in North-East Scotland. Soil Use and Management, v.4, p.102-107, 1988.

BLACKWELL, D. Estatística básica. 2.ed. São Paulo: EDUSP, 1975. 143p.

BORGHI, E.; ROCHA, J.V.; LAMPARELLI, R.A.C. Comparação entre dois métodos de integração e de análise de dados para a agricultura de precisão. In: BALASTREIRE, L.A. O estado da arte da agricultura de precisão no Brasil. Piracicaba: O autor, 2000. p. 140 .

BOWERSOX, T.W.; WARD, W.W. Prediction of oak site in the ridge and valley region of Pennsylvania. Forest Science, v.18, n.3, p.192-195, 1972.

BRACCINI, M.C.L.; MARTINEZ, H.E.P.; PEREIRA, P.R.G. Tolerância de genótipos de cafeeiro ao alumínio em solução nutritiva. II. Teores de $\mathrm{P}, \mathrm{Ca}$ e $\mathrm{Al}$ e eficiência ao P e Ca. Revista Brasileira de Ciência do Solo, v.22, p.445-450, 1998.

BRADY, N.C. Natureza e propriedades dos solos. 7.ed. Rio de Janeiro: Freitas Bastos, 1989. 898p.

BRAIS, S.; CAMIRÉ, C. Keys for soil moisture regime evaluation for northwestern Quebec. Canadian Journal Forest Research, v.22, p.718-724, 1992.

BRAGA, F.A. Uso da análise discriminante na identificação de características ambientais determinantes da capacidade produtiva de povoamentos de eucalipto. Viçosa, 1997. 65p. Tese (Doutorado) - Universidade Federal de Viçosa.

BRAGA, F.A.; VALE, F.R.; MUNIZ, J.A. Movimentação de nutrientes no solo, crescimento e nutrição mineral do eucalipto, em função de doses de gesso e níveis de irrigação. Revista Brasileira de Ciência do Solo, v.19, n.1, p.69-77, 1995.

BRAGA, F.A.; BARROS, N.F.; SOUZA, A.L.; COSTA, L.M. Características ambientais determinantes da capacidade produtiva de sítios cultivados com eucalipto. Revista Brasileira de Ciência do Solo, v.23, n.2, p.291-298, 1999.

BRASIL. Ministério da Agricultura. Levantamento e reconhecimento dos solos do Estado de São Paulo: contribuição à Carta de Solos do Brasil. Rio de Janeiro: Serviço Nacional de Pesquisas Agronômicas, 1960. 634p. (Boletim, 12). 
BREGT, A.K.; McBRATNEY, A.B.; WOPEREIS, M.C.S. Construction of isolinear maps of soil attributes with empirical confidence limits. Soil Science Society of America Journal, v.55, n.1, p.14-19, 1991.

BROADFOOT, W.M. Problems in relating soil site index for southern hardwoods. Forest Science, v.15, n.4, p.354-364, 1969.

BRUM, E.T. Relações entre a altura dominante e fatores de sítio em povoamentos de Pinus elliottii na região de Ponte Alta do Norte, SC. Curitiba, 1979. 190p. Dissertação (Mestrado) - Universidade Federal do Paraná.

BUENO, N. Quantidade de alumínio no substrato afetando o desenvolvimento e sintomatologia de toxicidade, a concentração e o acúmulo de macronutrientes em seringueira (Hevea ssp). Piracicaba, 1987. 92p. Tese (Doutorado) - Escola Superior de Agricultura "Luiz de Queiroz", Universidade de São Paulo.

CAHN, M.D.; HUMMEL, J.W.; BROUER, B.H. Spatial analysis of fertility for sitespecific crop management. Soil Science Society of America Journal, v.58, p.12401248, 1994.

CALLAWAY, R.M.; CLEBSCH, E.C.; WHITE, P.S. A multivariate analysis of forest communities in Western Great Smoky Mountains National ParK. American Midland Natualist, v.118, n.1, p.107-120, 1987.

CÂMARA, G. Anatomia de sistemas de informações geográficas: visão atual e perspectivas de evolução. In: ASSAD, E.D.; SANO, E.E. Sistemas de Informações Geográficas: aplicações na agricultura. Brasília: EMBRAPA, 1993. p.15-37.

CAMARGO, E.C.G. Desenvolvimento, implementação e teste de procedimentos geoestatísticos (krigeagem) no sistema de processamento de informações georreferenciadas (Spring). São José dos Campos, 1997. 123p. Dissertação (Mestrado) - Instituto Nacional de Pesquisas Espaciais.

CAMARGO, A.O. de; MONIZ, A.C.; JORGE, J.A.; VALADARES, J.M.A.S. Métodos de análise química, mineralógica e física de solos do IAC. Campinas: IAC, 1986. 94p. (IAC. Boletim Técnico, 106). 
CAMBARDELLA, C.A.; MOORMAN, T.B.; NOVAK, J.M.; PARKIN, T.B.; KARLEN, D.L.; TURCO, R.F.; KONOPKA, A.E. Fieldscale variability of soil properties in Central Iowa soils. Soil Science Society of America Journal, v.58, p.1501-1511, 1994.

CAMERON, D.R. Variability of soil water retention curves and predicted hydraulic conductivities on a small plot. Soil Science, v.126, n. 6, p.364-371, 1978.

CAMPOS, H. Estatística experimental não-paramétrica. 3.ed. São Paulo: ESALQ, 1979. 343p.

CAMPOS, J.C.C.; LEITE, H.G.; LELIS, V.G.S. Classificação da capacidade produtiva de Eucalyptus camaldulensis na região de João Pinheiro, em Minas Gerais. Boletim Técnico de Investigações Florestais, n.2, p.1-7, 1991.

CARDENAS, A.C. Exportação de nutrientes e produtividade de povoamentos de eucalipto no litoral norte do Espírito Santo. Viçosa, 1987. 98p. Dissertação (Mestrado) - Universidade Federal de Viçosa.

CARMEAN, W.H. Black oak site quality in relation to soil and topography in southeastern Ohio. Soil Science Society of America Proceedings, v.29, n.3, p.308$312,1965$.

CARMEAN, W.H. Soil survey refinements for predicting black oak site quality in Southeastern Ohio. Soil Science Society America Proceedings, v.31, n.6, p.805$810,1967$.

CARMEAN, W.H. Tree height-growth patterns in relation to soil and site. In: NORTH AMERICAN FOREST SOILS CONFERENCE, 3., Corvallis, 1968. Proceedings. Corvallis: Oregon State University, 1968. p.499-512.

CARMEAN, W.H. Forest site quality evaluation in the United States. Advances in Agronomy, v.27, p.209-269, 1975.

CARMO, D.N.C.; RESENDE, M.; SILVA, T.C.A. Avaliação da aptidão das terras para eucalipto. In: BARROS, N.F.; NOVAIS, R.F. Relação solo-eucalipto. Viçosa: Editora Folha de Viçosa, 1990. p.187-235. 
CARVALHO, T.M. de. Variabilidade espacial de propriedades físico-hídricas de em um latossolo vermelho-amarelo através da geoestatística. Lavras, 1991. 84p. Dissertação (Mestrado) - Escola Superior de Agricultura de Lavras.

CASTÃÑNOS, L.J.N. Evaluación de la calidad de estación de pino patula en el Norte de Oaxaca. México: Instituto Nacional de Investigaciones Forestales, 1962. 32p. (Boletim Técnico, 2).

CIHA, A.J. Slope position and grain yield of soft white winter wheat. Agronomy Journal, v.76, p.193-196, 1984.

COILE, T.S. Soil and the growth of forests. Advances in Agronomy, v.4, p.330-398, 1952.

COMPANHIA SUZANO DE PAPEL E CELULOSE. Valores de temperatura e precipitação atmosférica do Município de Paraibuna-SP no período de 1986 a 1996. Moji das Cruzes: Divisão de Recursos Naturais, 1997.

CONDE, M.R.; CORNACCHIONI, L.A. Os frutos do SIG: a experiência da Companhia Suzano de Papel e Celulose. Revista Fator GIS, v.2, n.7, p.40-41, nov./dez. 1994.

CORREIA, J.R. Uso de técnicas multivariadas no estudo das inter-relações de características do solo e a produtividade do eucalipto. Viçosa, 1993. 106p. Dissertação (Mestrado) - Universidade Federal de Viçosa.

CORREIA, J.R.; COSTA, L.M. da; NEVES, J.C.L.; CRUZ, C.D. Análise de trilha ("Path Analysis") no estudo do relacionamento entre características físicas e químicas do solo e a produtividade do eucalipto. Revista Árvore, v.20, n.2, p.161169, abr./jun. 1996.

COSTA, L.M. da; CARMO, D.N. Aspectos de manejo de solos em áreas de reflorestamento no Brasil. In: SIMPÓSIO DE FLORESTAS PLANTADAS NOS NEOTRÓPICOS COMO FONTE DE ENERGIA, 1., Viçosa, 1983. Anais. Viçosa: UFV, 1985. p.118-132. 
COSTA, L.G.; JESUS, D. de; NIELSEN, I. R. Planejamento do uso do solo na Champion Papel e Celulose, utilizando sistema de informações geográficas (compact disc). In: SEMINÁRIO DE ATUALIZAÇÃO EM SENSORIAMENTO REMOTO E SISTEMAS DE INFORMAÇÕES GEOGRÁFICAS APLICADOS A ENGENHARIA FLORESTAL, 4., Curitiba, 2000. Anais. Curitiba, 2000.

COSTA NETO, P.L.O. Estatística. 10.ed. São Paulo: Edgard Blücher, 1990. 264p.

COURSEUIL, C.W.; MADRUGA, P.R.A. Modelagem numérica em mapa temático: sítios florestais. Ciência Rural, v.28, n.4, p.691-694, out./dez. 1998.

COUTO, H.T.Z. do. Sistemas de informações geográficas: aplicações florestais. Série Técnica IPEF, v.28, n.9, p.1-18, 1993.

CUNHA NETO, F.R.; SCOLFORO, J.R.S.; OLIVEIRA, A.D.; CALEGÁRIO, N.; KANEGAE JUNIOR, H. Uso da diferença algébrica para construção de curva de índice de sítio para Eucalyptus grandis e Eucalyptus urophylla, na região de Luiz Antonio-SP, Cerne, v.2, n.2, p.119-141, 1996.

DÁRIO, F.R. Influência de corredor florestal entre fragmentos da mata atlântica utilizando-se a avifauna como indicador ecológico. Piracicaba, 1999. 172p. Dissertação (Mestrado) - Escola Superior de Agricultura "Luiz de Queiroz", Universidade de São Paulo.

DAVIS, K.P. Forest management, regulation and evaluation. New York: Mc Graw Hill, 1966. 519p.

DE BIASI, M. Carta de declividade de vertentes: confecção e utilização. Geomorfologia, n.21, p.8-13, 1970.

DE BIASI, M. A carta clinográfica: os métodos de representação e sua confecção. Revista Geográfica, n.6, p.45-61, 1992.

DE BIASI, M.; SIMIELLI, M.E.R.; LUCCHESI, E.S.; OMAKI, N.E. Cartas de orientação de vertentes: confecção e utilização. Cartografia, n.4, p.1-12, 1977.

DELLA-BIANCA, L.; OLSON JR., D.F. Soil-site studies in Piedmont hardwood and pine-hardwood upland forests. Forest Science, v.7, n.4, p.320-309, 1961. 
DEMENT, J.A.; STONE, E.L. Influence of soil and site on red pine plantations in New York: soil type and physical properties. Ithaca: Comell University, Agriculture Experiment Station, 1968. 25p. (Bulletin, 1020).

DOOLITTLE, W.T. Site index of Scarlet and Black Oak in relation to Southern Appalachian soil and topography. Forest Science, v.3, n.2, p.114-124, 1957.

DOUGLAS, B.W.; MACLEOD, J.A.; MELLISH, T.M.; GLEN, W.M.; THOMPSON, B.L.; DEHAAN, K.R.; STURZ, A.V.; CARTER, M.R.; BRIMACOMBE, M.B. A method for measuring Prince Edward Island soil quality. Communications in Soil Science and Plant Analysis, v.31, n.11-14, p.1837-1845, 2000.

EASTMAN, J.R. Idrisi32, version 32.11: software de sistemas de informação geográfica (software). Worcester: Clark University, 1998.

EGUCHI, E.S. Variabilidade espacial de atributos físico-hídricos de um solo hidromórfico no município de Lavras-MG. Lavras, 2001. 85p. Dissertação (Mestrado) - Universidade Federal de Lavras.

EMPRESA BRASILEIRA DE PESQUISA AGROPECUÁRIA. Manual de métodos de análise de solo. Rio de Janeiro: Serviço Nacional de Levantamento e Conservação de Solos, 1979.

EMPRESA BRASILEIRA DE PESQUISA AGROPECUÁRIA. Manual de métodos de análise de solo. 2.ed. Rio de Janeiro: Centro Nacional de Pesquisa de Solos, 1997. $212 \mathrm{p}$.

ENGLUND, E.; SPARKS, A. Geo-EAS - Geoeastistical Enviromental Assessment Software: software de análise geoestatística (software). Las Vegas: Environmental Protection Agency, 1991. v.1, 100p.

FABRES, A.S.; BARROS, N.F.; NOVAIS, R.F. Produtividade e exportação de nutrientes em eucaliptos e identificação de sítios visando o manejo do solo e o manejo florestal em áreas da CENIBRA. Relatório Anual/Programa 86-87, Viçosa: Convênio SIF/UFV, 1987. 142p.

FAÇANHA, J.G.V. Aspectos fisiológicos do crescimento de Eucalyptus spp. submetidos a deficiência hídrica. Viçosa, 1983. 47p. Dissertação (Mestrado) - Universidade Federal deViçosa. 
FANQUIM, V.; VALE, F.R. Toxidez de alumínio e de manganês. Informe Agropecuário, v.15, n.170, p.28-38, 1991.

FARIAS, M.S.S. de. Diagnóstico da necessidade de drenagem no perímetro irrigado de São Gonçalo. Campina Grande, 1999. Paraíba, 75p. Dissertação (Mestrado) Universidade Federal da Paraíba.

FARNSWORTH, C.E.; LEAF, A.L. An approach to soil site problems: sugar maple-soil relations in New York. In: NORTH AMERICAN FOREST SOILS CONFERENCE, 2., Corvallis, 1963. Forest-soils relationships in North America. Corvallis: Oregon State University Press, 1963. p. 279-298.

FELGUEIRAS, C.A. Desenvolvimento de um sistema de modelagem digital de terreno para microcomputadores. São José dos Campos, 1987. 243p. Dissertação (Mestrado) - Instituto Nacional de Pesquisas Espaciais.

FERREIRA, C.A; COUTO, H.T.Z. do. A influência de variáveis ambientais no crescimento de espécies/procedências de Eucalyptus spp nos Estados de Minas Gerais e Espírito Santo. Boletim de Pesquisa Florestal. n.3, Curitiba, p.09-36, 1981.

FIETZ, C.R. Variabilidade espacial do armazenamento de água no solo visando o manejo da irrigação por aspersão. Piracicaba, 1998. 97p. Tese (Doutorado) - Escola Superior de Agricultura "Luiz de Queiroz", Universidade de São Paulo.

FINCHER, J.; SMITH, M.L. A discriminant-function approach to ecological site classification in Northern New England. Radnor: USDA-Forest Service, 1994. 12p. (Research Paper, NE-686)

FINGER, C.A.G. Fundamentos de biometria florestal. Santa Maria: UFSM, CEPEFFATEC, 1992. 269p.

FOLEGATTI, M.V. Estabilidade temporal e variabilidade espacial da umidade e do armazenamento de água em solo siltoso, 1996. Piracicaba, 84p. Tese (Livre Docência) - Escola Superior de Agricultura "Luiz de Queiroz", Universidade de São Paulo. 
FOY, C.D. Physiological effects of hydrogen, aluminium, and manganese toxicities in acid soil. In: ADAMS, F. Soil acidity and liming. 2.ed. Madison: Soil Science Society of America, 1984. p.57-97.

FOY, C.D. Plant adaptation to acid, aluminium-toxic soils. Communications in Soil Science and Plant Analysis, v.9, p.959-987, 1988.

FOY, C.D. Soil chemical factors limiting plant root growth. In: HATFIEL; J.L.; STEWART, B.A. Limitations to plant root growth. New York: Springer-Verlag, 1992. p.97-149.

FRANCO, A.P.B.; SPAROVEK, G.; SIGRIST, P. Integração GPS/SIG para planejamento agropecuário (compact disc). In: CONGRESSO E FEIRA PARA USUÁRIOS DE GEOPROCESSAMENTO DA AMÉRICA LATINA - GIS BRASIL 98, 4., Curitiba, 1998. Anais. Curitiba, 1998.

GALBIATTI, J.A. Efeito de rampas com 0 e $20 \%$ de declividade, exposições norte e sul, sobre a umidade e temperatura do solo e comportamento do Sorgum bicolor (L.) Moench. Jaboticabal, 1978. 73p. Dissertação (Mestrado) - Universidade Estadual Paulista "Júlio de Mesquita Filho".

GAMMA DESIGN SOFTWARE. GS+ Geostatistics for the environmental sciences, version 3.1.8.8 Demonstration: software de análise geoestatística (software). Michigan, 1998.

GARCIA Y GARCIA, A. Variabilidade espacial de atributos físicos do solo e resposta espectral da cultura de feijão irrigado, em imagens aéreas digitais. Piracicaba, 1997. 79p. Dissertação (Mestrado) - Escola Superior de Agricultura "Luiz de Queiroz", Universidade de São Paulo.

GATTO, A. Manejo do solo em áreas de reforma de floresta de eucalipto e seus reflexos na produtividade. Viçosa, 2000. 62p. Dissertação (Mestrado) - Universidade Federal de Viçosa.

GEYER, W.A.; MARQUARD, R.D.; BARBER, J.F. Black walnut site quality in relation to soil and topographic characteristics in Northeastern Kansas. Journal of Soil and Water Conservations, v.35, n.3, p.135-137, 1980. 
GHOLZ, H.L.; EWEL, K.C.; TESKEY, R.O. Water and forest productivity. Forest Ecology and Management, v.30, p.1-18, 1990.

GIRARDIN, J.L.; BROQUEN, P. El crecimiento de Pinus ponderosa Dougl. Y Pseudotsuga menziessii Mirb. en diferentes condiciones de sítio. Bosque, v.16, n.2, p.57-67, 1995.

GOLDEN SOFTWARE. Surfer for Windows, version 6.01: software de geração de mapas de contorno e superfícies contínuas (software). Colorado, 1995.

GOMES, F.P.; ZEN, S. A produtividade do eucalipto em função das variáveis físicas e químicas do solo. Revista de Agricultura. v.70, n.2, p.139-143, set. 1995.

GOMES, R.T. Efeito do espaçamento no crescimento e nas relações hídricas de Eucalyptus spp. na região de cerrado de Minas Gerais. Viçosa, 1994. 85p. Dissertação (Mestrado) - Universidade Federal de Viçosa.

GOMES, S.S. Efeitos do alumínio e mecanismo de tolerância à toxidade em espécies de Eucalyptus e Pinus. Piracicaba, 2001. 38p. Dissertação (Mestrado) - Escola Superior de Agricultura "Luiz de Queiroz", Universidade de São Paulo.

GONÇALVES, A.C.A. Variabilidade espacial de propriedades físicas do solo para fins de manejo da irrigação. Piracicaba, 1997. 118p. Tese (Doutorado) - Escola Superior de Agricultura "Luiz de Queiroz", Universidade de São Paulo.

GONÇALVES, J.C. Comportamento do Eucalyptus grandis Hill ex Maiden em dois solos de baixa fertilidade, em Angatuba-SP. Piracicaba, 1987. 71p. Dissertação (Mestrado) - Escola Superior de Agricultura "Luiz de Queiroz", Universidade de São Paulo.

GONÇALVES, J.L.M. Interpretação de levantamento de solo para fins silviculturais. IPEF, v.39, p.65-72, 1988.

GONÇALVES, J.L.M. Interações genótipo-ambiente e relações entre a produtividade de sítios florestais de Eucalyptus grandis e Eucalyptus saligna com as propriedades de alguns solos de textura arenosa e média no Estado de São Paulo. Piracicaba, 1990. 135p. Tese (Doutorado) - Escola Superior de Agricultura "Luiz de Queiroz", Universidade de São Paulo. 
GONÇALVES, J.L.M.; COUTO, H.T.Z. do; DEMATTÊ, J.L.I. Relações entre a produtividade de sítios florestais de Eucalyptus grandis e Eucalyptus saligna com as propriedades de alguns solos de textura arenosa e média no Estado de São Paulo. IPEF, n. 43/44, p.24-39, 1990.

GONÇALVES, J.L.M.; BARROS, N.F.; NEVES, J.C.L.; NOVAIS, R.F. Níveis críticos de fósforo no solo e na parte aérea de eucalipto na presença e ausência de calagem. Revista Árvore, v.10, n.1, p.91-104, 1986.

GOOR, C.P.V. A nutrição de alguns pinheiros tropicais. Silvicultura em São Paulo, V.4/5, n.4, p.313-340, 1965/66.

GOOR, C.P.V. Aspectos ecológicos dos plantios na região sul, particularmente com Pinus elliottii e Araucária angustifolia. Boletim Serviço Florestal, n.9, p.1-58, 1965a.

GOOR, C.P.V. Reflorestamento com coníferas no Brasil. Boletim Setor de Inventários Florestais, v.9, p.1-58, 1965 b.

GOOR, C.P.V.; NASCIMENTO, R. Relatório sobre pesquisa adicional em Araucaria angustifolia e em Pinus spp. Rio de Janeiro: Instituto Brasileiro de Desenvolvimento Florestal, 1969. 13p.

GRANEY, D.L.; FERGUSON, E.R. Site quality relationship for shortleaf pine in the Boston mountains of Arkansas. Forest Science, v.17, n.1, p.16-22, 1971.

GRANEY, D.L.; FERGUSON, E.R. Shortleaf pine site-index relationships in the Ozark Highlands. Soil Science Society of America Proceedings, v.36, n.3, p.495-500, 1972.

GRESPAN, S.L. Produção e eficiência nutricional de clones de eucalipto no norte do Espírito Santo e suas relações com características do solo. Viçosa, 1997. 81p. Dissertação (Mestrado) - Universidade Federal de Viçosa.

GREY, D.C. Site quality prediction for Pinus patula in the Glengarry area, Transkei. Southern African Forestry Journal, n.111, p.44-48, 1979.

GREY, D.C. Site classification of forestry land. Southern African Forestry Journal, n.138, p.54-57, 1985. 
HAAG, H.P.; MELLO, H.A.; MELLO, F.A.F.; BRASIL SOBRINHO, M.O.C.; VEIGA, A.A. Composição química do E. alba Reinw e E. grandis (Mill) Maiden: resultados preliminares. Fertilité, v.18, p.9-14, 1963.

HANNA, A.Y.; HARLAN, P.W.; LEWIS, D.T. Soil available water as influenced by landscape position and aspect. Agronomy Journal, v.74, p.999-1004, 1982.

HANNAH, P.R. Estimating site index for white and black oaks in Indiana from soil and topographical factors. Journal of Forestry, v.66, n.5, p.412-417, 1968a.

HANNAH, P.R. Topography \& soils relations for white and black oak in Southern Indiana. Washington: Forest Service, 1968b. 7p. (Research Paper, NC-25).

HANNAH, P.R. Soil-site relationships for white, scotch and red pine plantations in Vermont. Burlington: University of Vermont, Agriculture Experiment Station, 1971. 27p. (Bulletin, 667).

HARDING, R.B.; GRIGAL, D.F.; WHITE, E.H. Site quality evaluation for white Spruce plantations using discriminant analysis. Soil Science Society of America Journal, v.49, n.1, p.229-232, 1985.

HARTUNG, R.E.; LLOYD, W.J. Influence of aspect on forest of the Clarksville soils in Dent County, Missouri. Journal of Forestry, v.67, n.3, p.178-182, 1969.

HAWKINS, D.M.; CRESSIE, N. Robust kriging - a proposal. Mathematical Geology, v.16, n.1, p.3-19, 1984.

HILLS, G.A. An integrated iterative approach to ecosystem classification. In: MEETING CANADA COMMITTEE ON ECOLOGICAL (BIOPHYSICAL) LAND CLASSIFICATION, 1., Petawawa, 1976. Proceedings. Petawawa: s.n., 1976. p.7397.

HIX, D.M. Multifactor classification and analysis of upland hardwood forest ecosystems of the Kickapoo River Watershed, south western Wisconsin. Canadian Journal of Forest Research, v.18, p. 1405-1415, 1988.

HOAGLIN, D.C.; MOSTELLER, F.; TYKEY, J.W. Análise exploratória de dados: técnicas robustas, um guia. Lisboa: Salamandra, 1983. 446p. 
HOOGH, R.J. de; DIETRICH, A.B. Avaliação de sítio para Araucária angustifolia (BERT) O. KTZE em povoamentos artificiais. Brasil Florestal, v.37, p.19-71, jan./mar. 1979.

HUSCH, B.; MILLER, I.C.; BEERS, T.W. Forest mensuration. New York: John Wiley, 1982. 402p.

KLEIN, J.E.M.; BERGER, R.; BAZZO, J.L.; POLIPO, L.C.; CÉZAR, M.R.A. Avaliação dos custos de produção de madeira em pé e da produção de povoamentos clonais e convencionais de Eucalyptus saligna SMITH, implantados sob diferentes espaçamentos. In: SIMPÓSIO LATINO-AMERICANO SOBRE MANEJO FLORESTAL, 1., Santa Maria, 2000. Anais. Santa Maria: UFSM, 2000. p.237-248.

KOZLOWSKI, T.T. Water supply and tree growth: water deficits. Forestry Abstracts, v.43, p.57-95, 1982.

KOZLOWSKI, T.T.; KRAMER, P.J.; PALLARDY, S.G. The physiological ecology of woody plants. San Diego: Academic Press, 1991. 657p.

INOUE, N.; XAVIER, S.R.; ROMANEL, C. Análise geoestatística do subsolo da usina nuclear de Angra 2 (compact disc). In: CONGRESSO E FEIRA PARA USUÁRIOS DE GEOPROCESSAMENTO DA AMÉRICA LATINA - GIS BRASIL 99, 5., Salvador, 1999. Anais. Salvador, 1999.

INSTITUTO DE PESQUISAS TECNOLÓGICAS DO ESTADO DE SÃO PAULO. Mapa geomorfológico do Estado de São Paulo. São Paulo, 1981a. 2v.

INSTITUTO DE PESQUISAS TECNOLÓGICAS DO ESTADO DE SÃO PAULO. Mapa geológico do Estado de São Paulo. São Paulo, 1981b. 2v.

INSTITUTO DA POTASSA \& FOSFATO. Manual internacional de fertilidade do solo. 2 ed. Piracicaba: POTAFOS, 1998. 177p.

ISAAKS, E.H.; SRIVASTAVA, R.M. An introduction to applied geostatistes. New York: Oxford University Press, 1989. 561p.

JACKSON, D.S. Parameters of site for certain growth components of slash pine (Pinus elliottii, Engelm.). Durham: Duke University, School of Forestry, 1962. 118p. (Bulletin, 16). 
JAKOB, A.A.E.; ROCHA, J.V.; LAMPARELLI, R.A.C. Estudo da correlação entre mapas de variabilidade de propriedades do solo e mapas de produtividade para fins de agricultura de precisão (compact disc). In: CONGRESSO E FEIRA PARA USUÁRIOS DE GEOPROCESSAMENTO DA AMÉRICA LATINA - GIS BRASIL 99, 5., Salvador, 1999. Anais. Salvador, 1999.

JAIYEOBA, I.A. Changes in soil properties related to different land uses in part of the Nigerian semi-arid Savannah. Soil Use and Management, v.11, p.84-89, 1995.

JUO, A.S.R.; LAL, R. The effects of fallow and continuous cultivation on the chemical and physical properties of an Alfison in western Nigeria. Plant and Soil, v.47, p.567-584, 1977.

LA BASTIDE, J.G.A.; GOOR, C.P.V. Growth site relationships in plantations of Pinus elliottii and Araucaria angustifolia in Brazil. Plant and Soil, v.32, p.349-366, 1970.

LAMPARELLI, R.A.C.; ROCHA, J.V.; BORGHI, E. Geoprocessamento e agricultura de precisão: fundamentos e aplicações. Guaíba: Agropecuária, 2001. 118p.

LARCHER, W. Phisiological plant ecology. New York: Springer-Verlag, 1975. 252p.

LEAL, J.C.G. Mapeamento da produtividade na colheita mecanizada do café. Piracicaba, 2002. 74p. Dissertação (Mestrado) - Escola Superior de Agricultura "Luiz de Queiroz", Universidade de São Paulo.

LEE, R. Forest microclimatology. New York: Columbia University Press, 1978. 276p.

LEE, R.; SYPOLT, C.R. Toward a biophysical evaluation of forest site potencial. Forest Science, v.20, p.145-154, 1974.

LEITE, F.P. Crescimento, relações hídricas, nutricionais e lumínicas em povoamento de Eucalyptus grandis em diferentes densidades populacionais. Viçosa, 1996. 90p. Dissertação (Mestrado) - Universidade Estadual de Viçosa.

LEVITT, J. Water, radiation, salt, and other stresses. In: LEVITT, J. Responses of plants to environmental stresses, 2.ed. New York: Academic Press Inc., 1980. $607 \mathrm{p}$.

LIANI, A. The absorption of phosphate in Eucalyptus trabuttii. In: CONGRESSO FLORESTAL MUNDIAL, 6., Madrid, 1966. Actas. Madrid, 1968. v.2. p.16551658. 
LIBARDI, P.L.; MANFRON, P.A.; MORAES, S.O.; TUON, R.L. Variabilidade da umidade gravimétrica de um solo hidromórfico. Revista Brasileira de Ciência do Solo, v.20, n.1, p.1-12, 1996.

LINNARTZ, N.E. Relation of soil and topographic characteristics to site quality for southern pines in the Florida Parishes Lousiana. Journal of Forestry, v.61, n.6, p.434-437, 1963.

LOPES, R.L. Efeitos da exposição sobre o microclima da cultura de sorgo (Sorghum vulgare Pers.). Jaboticabal, 1973. 105p. Tese (Doutorado) - Universidade Estadual Paulista "Júlio de Mesquita Filho".

MALAVOLTA, E. Elementos de nutrição mineral de plantas. São Paulo: Editora Agronômica Ceres, 1980. 251p.

MARQUES JUNIOR, J.; SANCHEZ, R.B.; PEREIRA, G.T.; CORÁ, J.E. Variabilidade espacial de propriedade químicas e físicas de latossolos em áreas de cerrado sob cultivo de café, em Patrocínio, MG. In: BALASTREIRE, L.A. O estado da arte da agricultura de precisão no Brasil. Piracicaba: O autor, 2000. p.105-112.

MARSCHNER, H. Mineral nutrition of higher plants. Institute of Plant Nutrition: University of Hohenheim, 1986. 674p.

MATA, J.D.V. da. Variabilidade espacial de indicadores da compactação de terra roxa estruturada, sob dois sistemas de preparo, cultivada com feijão (Phaseolus vulgaris L.) irrigado. Piracicaba, 1997. 73p. Tese (Doutorado) - Escola Superior de Agricultura "Luiz de Queiroz", Universidade de São Paulo.

MCCOOL, J.C. Soil plant relationships in Eucalyptus forest on the South Coast of New South Wales. Ecology, v.50, n.5, p.354-361, 1969.

MCGAUGHEY, R.J. Using data-driven visual simulations to support forest operations planning. In: INTERNATIONAL PRECISION FORESTRY COOPERATIVE SYMPOSIUM, 1., Seattle, 2001. Proceedings. Seattle: University of Washington College of Forest Resources, 2001. p.173-179.

MEAD, R.; CURNOW, R.W. Statistical methods in agriculture and experimental biology. New York: Chapman and Hall, 1983. 163p. 
MEEUWIG, R.O.; COOPER, S.V. Site quality and growth of Pinyon-Juniper stands in Nevada. Forest Science, v.27, n.3, p.593-601, 1981.

MEINERS, T.M.; SMITH, D,W.; SHARIK, T.L.; BECK. D.E. Soil and plant water stress in an Appalachian oak forest in relation to topography and stand age. Plant and Soil, v.80, n.2, p.171-179, 1984.

MELO, V.F. Relação entre a reserva mineral de solos e a produção e nutrientes em povoamentos de Eucalyptus saligna Smith, no Rio Grande do Sul. Viçosa, 1994. 145p. Dissertação (Mestrado) - Universidade Federal de Viçosa.

MELLO, V.F.; CRUZ, C.D.; BARROS, N.F. de; NOVAIS, R.F. de; COSTA, L.M. da. Utilização de técnicas multivariadas no estudo das relações entre atributos químicos do solo e a produtividade do eucalipto no Rio Grande do Sul. IPEF, n.48/49, p.3849, 1995.

MENDES, W. Relação entre os graus de limitações do uso do solo por suscetibilidade à erosão e às unidades de mapeamento do solo. Revista Brasileira de Geografia, v.44, n.3, p.445-476, jul./set. 1982.

METRO, A. El eucalipto en la repoblación florestal. 2.ed. Roma: FAO, 1966. 431p.

MICROSOFT CORPORATION. Microsoft Excel, versão 4.10: software de análise estatística (software). USA, 1998.

MONBEIG, P. A divisão regional do Estado de São Paulo. Anuário da Associação Geográfica Brasileira, n.1, p.19-30, 1949.

MORETTI, E.; KOFFLER, N.F.; TEIXEIRA, A.L.A. Técnicas digitais para mapeamento da declividade e orientação de vertentes baseadas no uso de sistemas de informação geográfica. Boletim de Geografia Teorética, v.19, n.37/38, p.29-52, 1989.

MORRIS, D.M.; PARKER, W.H. Variable-quality form in mature jack pine stands: quantification and relationship with environmental factors. Canadian Journal of Forest Research, n.22, p. 279-289, 1992.

MULLA, D.J. Mapping and managing spatial patterns in soil fertility and crop yield. In: ROBERT, P.C.; RUST, R.H.; LARSON, W.E. Soil specific crop management. Madison: ASA-CSSA-SSSA, 1993. p.15-26. 
MULLA, D.J.; BHATTI, A.U.; HAMMOND, M.W.; BENSON, J.A. A comparasion of winter wheat yield and quality under uniform versus spatially variable fertilizer management. Agriculture Ecosystems and Environment, v.38, p.301-311, 1992.

MYERS, C.A.; DEUSEN, J.L. van. Site index of ponderosa pine in the Black Hills from soil and topography. Journal of Forestry, v.58, n.7, p.548-555, 1960.

NAKAJIMA, N.Y.; KIRCHNER, F.F.; SANQUETTA, C.R.; POSONSKI, M. Comparação de dois métodos de amostragem na estimativa de valores correntes em inventários florestais. In: SIMPÓSIO LATINO-AMERICANO SOBRE MANEJO FLORESTAL, 1., Santa Maria (RS), 2000. Anais. Santa Maria: UFSM, 2000. p.399414.

NAMBIAR, E.K.S. Significance of first-order lateral roots on the growth of young radiata pine under environmental stress. Australian Forest Research, v.14, p.187199, 1984.

NEVES, J.C.L. Aspectos nutricionais em mudas de Eucalyptus spp. - tolerância ao alumínio e níveis críticos de fósforo no solo, 1983, Viçosa. 97p. Dissertação (Mestrado) - Universidade Federal de Viçosa.

NEVES, J.C.L.; GOMES, J.M.; NOVAIS, R.F. Fertilização mineral de mudas de eucalipto. In: BARROS, N.F.; NOVAIS, R.F. Relação solo-eucalipto. Viçosa: Editora Folha de Viçosa, 1990. p.99-126.

NEVES, J.C.L.; NOVAIS, R.F; BARROS, N.F. Efeito do alumínio em solução nutritiva no crescimento e absorção de nutrientes por Eucalyptus spp. Revista Árvore, v.6, n.1, p.1-16, 1982a.

NEVES, J.C.L.; BARROS, N.F.; NOVAIS, R.F; ANJOS, J.L. Efeito do alumínio em amostras de dois latossolos sob cerrado sobre o crescimento e a absorção de nutrientes de mudas de Eucalyptus spp. Revista Árvore, v.6, n.1, p.17-28, 1982 b.

NEWBERRY, J.D.; PIENAAR, L.V. Dominant height growth models and site index curves for site-prepared slash pine plantations in the lower coastal plain of Georgia and North Florida. Georgia: School of Forest Resources, University of Georgia, 1978. 48p. (Research Paper, 4). 
NIELSEN, D.R.; BIGGAR, J.W.; ERH, K.T. Spatial variability of field measured soil water properties. Hilgardia, v.42, n.7, p.215-259, 1973.

NOBEL, P.S. Introduction to biophysical plant phisiology. San Francisco: W.H. Freeman, 1974. 488p.

NOVAIS, R.F; BARROS, N.F.; NEVES, J.C.L. Nutrição mineral de mudas de eucalipto. In: BARROS, N.F.; NOVAIS, R.F. Relação solo-eucalipto. Viçosa: Editora Folha de Viçosa, 1990. p.25-98.

NOVAIS, R.F. de; MELLO, V.F.; BARROS, N.F. de; COSTA, L.M. da; FONTES, M.P.F. Balanço nutricional, eficiência de utilização e avaliação da fertilidade do solo em P, K, Ca e Mg em plantios de eucalipto no Rio Grande do Sul. IPEF, n.48/49, p.08-17, 1995

OLIVA, M.A.; BARROS, N.F.; GOMES, M.M.S.; LOPES, N.F. Seca de ponteiros em Eucalyptus camaldulensis Dehn em relação a estresse hídrico e nutrição mineral. Revista Árvore, v.13, n.1, p.19-33, 1989.

OLIVEIRA, R.A. de. Classificação de sítios em plantações de eucalipto pelo método de índices de local e por classe de solos e de precipitação, 1998, Viçosa. 84p. Dissertação (Mestrado) - Universidade Federal de Viçosa.

OLIVEIRA-FILHO, P.C.; FIGUEIREDO-FILHO, A.; KIRCHNER, F.F.; MEDEIROS, J. S.; OLIVEIRA, E.B. Uso de geotecnologias na gestão da empresa florestal (compact disc). In: SEMINÁRIO DE ATUALIZAÇÃO EM SENSORIAMENTO REMOTO E SISTEMAS DE INFORMAÇÕES GEOGRÁFICAS APLICADOS A ENGENHARIA FLORESTAL, 4., Curitiba, 2000. Anais. Curitiba, 2000.

ORTIZ, G.C. Aplicação de métodos geoestatísticos para identificar a magnitude e a estrutura da variabilidade espacial de variáveis físicas do solo, 2002, Piracicaba. 75p. Dissertação (Mestrado) - Escola Superior de Agricultura "Luiz de Queiroz", Universidade de São Paulo.

PAGNANO, N.B.; MAGALHÃES, P.S.G. Sistema de monitoramento da colheita da cana-de-açúcar para elaboração de mapas de rendimento (compact disc). In: CONGRESSO E FEIRA PARA USUÁRIOS DE GEOPROCESSAMENTO DA AMÉRICA LATINA - GIS BRASIL 99, 5., Salvador, 1999. Anais. Salvador, 1999. 
PAZ, A.; TABOADA, M.T.; GÓMEZ, M.J. Spatial variability in topsoil micronutrients contents in one-hectare cropland plot. Communication in Soil Science and Plant Analysis, v.27, n.3/4, p.479-503, 1996.

PAWLUK, S.; ARNEMAN, H.F. Some forest soil characteristics and their relationships to jack pine growth. Forest Science, v.7, n.2, p.160-173, 1961.

PAYN, T.W.; HILL, R.B.; HÖCK, B.K.; SKINNER, M.F.; THORN, A.J.; RIJKSE, W.C. Potential for the use of GIS and spatial analysis techniques as tools for monitoring changes in forest productivity and nutrition, a New Zealand example. Forest Ecology and Management, v.122, n.1/2, p.187-196, sept. 1999.

PEREIRA, J.S. Relações hídricas das árvores. Agronomia Lusitana, v.39, n.2/3, p.155$173,1979$.

PEREIRA, J.S.; KOZLOWSKI, T.T. Leaf anatomy and water relations of Eucalyptus camaldulensis and E. globulus seedlings. Canadian Journal of Botany, n.54, p.2868-2880, 1976.

PHILLIPS, J.J.; MARKLEY, M.L. Site index of New Jersey sweetgum stands related to soil and water-table characteristics. Washington: Forest Service, 1963. 25p. (Research Paper, NE-6).

PIEROSSI, M.A.; NEVES, J.L.M. Mapeamento de produtividade de cana-de-açúcar. In: BALASTREIRE, L.A. O estado da arte da agricultura de precisão no Brasil. Piracicaba: O autor, 2000. p.124-128.

PIMENTEL GOMES, F. Curso de estatística experimental. São Paulo: Nobel, 1985. $466 \mathrm{p}$.

POCAY, V.G. Relações entre pedoforma e variabilidade espacial de atributos de latossolos sob cultivo de cana-de-açúcar. Jaboticabal, 2000. 177p. Dissertação (Mestrado) - Universidade Estadual Paulista "Júlio de Mesquita Filho".

PREGITZER, K.S.; BARNES, B.V. Classification and comparison of upland hardwood and conifer ecosystems of the Cyrus H. McCormick Experimental Forest, upper Michigan. Canadian Journal of Forest Research, v.14, p.362-375, 1984. 
PREVEDELLO, B.M.S. Variabilidade espacial de parâmetros de solo e planta. Piracicaba, 1987. 166p. Tese (Doutorado) - Escola Superior de Agricultura "Luiz de Queiroz", Universidade de São Paulo.

PREZOTTI, L.C. Nível crítico de potássio no solo para a produção de mudas de eucalipto. Viçosa, 1985. 45p. Dissertação (Mestrado) - Universidade Federal de Viçosa.

QUEIROZ, J.E. Parâmetros hidrodinâmicos para um solo de várzea para fins de drenagem subterrânea. Piracicaba, 1995. 167p. Tese (Doutorado) - Escola Superior de Agricultura "Luiz de Queiroz", Universidade de São Paulo.

RADLOFF, D.L.; BETTERS, D.R. Multivariate analysis of physical site data for wildland classification. Forest Science, v.24, p.2-10, 1978.

RAIJ, B. van; ANDRADE, J.C. de; CANTARELlA, H.; QUAGGIO, J.A. Análise química para avaliação de solos tropicais. Campinas: IAC, 2001. 285p.

RALSTON, C.W. Evaluation of forest site produtivity. In: ROMBERGER, T.A.; MIKOLA, P. International review of forest research. New York: Academic Press, v.1, p.171-201, 1964.

RAMALHO, M.A.P. Emprego da seleção recorrente no melhoramento de essências florestais. In: SIMPÓSIO BRASILEIRO DE PESQUISA FLORESTAL, 1., Belo Horizonte, 1993. Anais. Belo Horizonte: SIF, 1993. p.21-37.

RAMALHO FILHO, A.; PEREIRA, E.G.; BEEK, K.J. Sistema de avaliação de aptidão agrícola das terras. Brasília: SUPLAN-MA/EMBRAPA, 1978. 70p.

REICHARDT, K.; VIEIRA, S.R.; LIBARDI, P.L. Variabilidade espacial de solos e experimentação de campo. Revista Brasileira de Ciência do Solo, v.10, n.1, p.1-6, 1986.

REIS, M.G.F.; BARROS, N.F. Ciclagem de nutrientes em plantios de eucalipto. In: BARROS, N.F.; NOVAIS, R.F. Relação solo-eucalipto. Viçosa: Editora Folha de Viçosa, 1990. p.265-301.

RENNIE, P.J. Methods of assessing forest site capacity. Commonwealth Forest Review, v.42, n.114, p.306-317, 1963. 
RESENDE, M. Aplicação de conhecimentos pedológicos à conservação de solos. Informe Agropecuário, v.11, n.128, p.3-18, 1985.

RESENDE, M.; CURI, N.; REZENDE, S.B.; CORRÊA, G.F. Pedologia: base para distinção de ambientes. 2.ed. Viçosa: NEPUT, 1997. 367p.

REZENDE, S.B. Estudo de crono-toposequência em Viçosa, Minas Gerais. Viçosa, 1971. 71p. Tese (Doutorado) - Universidade Federal de Viçosa.

RIBEIRO, A.C.; MELLO, J.W.V.; NOVAIS, R.F. Módulo 3: Propriedades físicoquímicas do solo. ASSOCIAÇÃO BRASILEIRA DE EDUCAÇÃO AGRÍCOLA SUPERIOR. Curso de fertilidade e manejo do solo. Brasília: ABEAS, 1996. 54p.

RIBEIRO, C.A.A.S. Floresta de precisão. In: MACHADO, C.C. Colheita florestal, Viçosa: UFV, 2002. p.311-335.

RIBEIRO JÚNIOR, P.J. Métodos geoestatísticos no estudo da variabilidade espacial dos parâmetros do solo, 1995, Piracicaba. 99p. Dissertação (Mestrado) - Escola Superior de Agricultura "Luiz de Queiroz", Universidade de São Paulo.

ROCHA, J.V.; LAMPARELLI, R.A.C. Do trabalho de campo ao processamento de mapas: um caso prático de agricultura de precisão no Brasil (compact disc). In: CONGRESSO E FEIRA PARA USUÁRIOS DE GEOPROCESSAMENTO DA AMÉRICA LATINA - GIS BRASIL 98, 4., Curitiba, 1998. Anais. Curitiba, 1998.

ROJAS VERGARA, P. Plantios clonais e multiclonais em relação a outros materiais genéticos de Eucalyptus grandis Hill ex. Maiden na região de Lençóis Paulista, SP. Piracicaba, 1989. 82p. Dissertação (Mestrado) - Escola Superior de Agricultura "Luiz de Queiroz", Universidade de São Paulo.

ROOK, D.A.; SWANSON, R.H.; CRANSWICK, A.M. Reaction of radiata pine to drought. In: SOIL AND PLANT WATER SYMPOSIUM, Palmerston North: New Zealand, 1976. p.55-67.

ROSA, R.; BRITO, J.L.S. Introdução ao Geoprocessamento: Sistema de Informação Geográfica. Uberlândia: EUDFU, 1996. 104p.

ROSAS, M.P. Alternativas de determinação da idade técnica de corte de Eucalyptus urophylla. Viçosa, 1994. 85p. Dissertação (Mestrado) - Universidade Federal de Viçosa. 
ROSS, J.L.S. Análise empírica da fragilidade dos ambientes naturais e antropizados. Revista do Departamento de Geografia, São Paulo, n.8, p.63-74, 1994.

SALVIANO, A.A.C. Variabilidade de atributos de solo e de Crotalaria juncea em solo degradado do município de Piracicaba-SP. Piracicaba, 1996. 91p. Tese (Doutorado) Escola Superior de Agricultura "Luiz de Queiroz", Universidade de São Paulo.

SALVIANO, A.A.C.; VIEIRA, S.R.; SPAROVEK, G. Dependência espacial dos teores de macronutrientes da parte aérea da Crotalária juncea em área de erosão acelerada. Revista Brasileira de Ciência do Solo, v.25, p.115-122, 1995.

SALVIANO, A.A.C.; VIEIRA, S.R.; SPAROVEK, G. Variabilidade de atributos de solo e de Crotalaria juncea em área severamente erodida. Revista Brasileira de Ciência do Solo, v.22, n.1, p.115-122, 1998.

SANDS, R.; MULLIGAN, D.R. Water and nutrient dynamics and tree growth. Forest Ecology and Management, v.30, p. 91-111, 1990.

SANTANA, J.A.S. Efeitos de propriedades dos solos na produtividade de duas espécies de eucalipto na região do Médio Rio Doce, MG. Viçosa, 1986. 117p. Dissertação (Mestrado) - Universidade Federal de Viçosa.

SANTOS, M.N. Levantamento das principais características do meio físico do município de Cerquilho-SP para fins de planejamento territorial. Rio Claro, 1996. 104p. Dissertação (Mestrado) - Universidade Estadual Paulista "Júlio de Mesquita Filho".

SAS INSTITUTE. SAS Procedures Guide, version 6.12: software de análise estatística (software). 3.ed. Cary, NC: SAS Institute, 1993. 1022p.

SCHONAU, A.P.G. Problems in using vegetation or soil classification in determining site quality. South African Forestry Journal, n.141, p.13-18, 1987.

SCHONAU, A.P.G.; ALDWORTH, W.J.K. Site evaluation in black wattle with special reference to soil factors. South African Forestry Journal, n.156, p.35-43, 1991.

SCHONAU, A. P. G.; PURNELL, R.C. A different approach to site evaluation and some preliminary results. South African Forestry Journal, n.141, p.19-25, 1987.

SCHNEIDER, P.R. Introdução ao manejo florestal. Santa Maria (RS): UFSM, 1993. $348 p$. 
SCHNEIDER, P.R. Influência do cesbaste e desrama no manejo de Eucalyptus spp. In: SIMPÓSIO LATINO-AMERICANO SOBRE MANEJO FLORESTAL, 1., Santa Maria, 2000. Anais. Santa Maria: UFSM, 2000. p.81-104.

SCOLFORO, J.R.S. Biometria florestal: métodos para classificação de sítios florestais. Lavras: UFLA/FAEPE, 1997. 151p.

SCOLFORO, J.R.S.; MACHADO, S.A. Curvas de índice de sítio para plantações de Pinus elliottii nos Estados do Paraná e Santa Catarina. Revista Floresta, v.17, p.140-158, 1988.

SCOTT, H.D.; MAUROMOUSTAKOS, A.; HANDAYANI, I.P.; MILLER, D.M. Temporal variability of selected properties of loessial soil as affected by cropping. Soil Science Society of America Journal, v.58, p.1531-1538, 1994.

SHIRATSUCHI, L.C. Mapeamento da variabilidade espacial das plantas daninhas com a utilização de ferramentas da agricultura de precisão, 2001, Piracicaba. 96p. Dissertação (Mestrado) - Escola Superior de Agricultura "Luiz de Queiroz", Universidade de São Paulo.

SHORTER, T.D. Efeitos do clima e do solo sobre o desenvolvimento de clones de Eucalyptus spp no sul da Bahia e sobre interações genótipo - ambiente. Piracicaba, 1993. 220p. Dissertação (Mestrado) - Escola Superior de Agricultura "Luiz de Queiroz", Universidade de São Paulo.

SILVA, A.P. Variabilidade espacial de atributos físicos do solo. Piracicaba, 1988. 105p. Tese (Doutorado) - Escola Superior de Agricultura "Luiz de Queiroz", Universidade de São Paulo.

SILVA JÚNIOR, M.C. Composição florística, estrutura e parâmetros fitossociológicos do cerrado e sua relação com o solo na Estação Florestal de Experimentação de Paraopeba, MG. Viçosa, 1984. 130p. Dissertação (Mestrado) - Universidade Federal de Viçosa.

SILVA JÚNIOR, R.L. da. Variabilidade espacial do índice de cone correlacionada com mapas de produtividade. Piracicaba, 2001. 132p. Dissertação (Mestrado) - Escola Superior de Agricultura "Luiz de Queiroz" - Universidade de São Paulo. 
SIMÕES, J.W.; BRANDI, R.M. Análise dos métodos silviculturais adotados em florestas implantadas para a produção de energia. In: SIMPÓSIO DE FLORESTAS PLANTADAS NOS NEOTRÓPICOS COMO FONTE DE ENERGIA, 1., Viçosa, 1983. Anais. Viçosa: UFV, 1985. p.79-94.

SOCIEDADE BRASILEIRA DE SILVICULTURA. Tabela de indicadores técnicos. IPEF on line, 1999. 2p.

SOUZA, L.C. de. Variabilidade espacial da salinidade de um solo aluvial no semi-árido paraibano. Campina Grande, 1999. 77p. Dissertação (Mestrado) - Universidade Federal da Paraíba.

SOUZA, L.S. Variabilidade espacial do solo em sistemas de manejo. Porto Alegre, 1992. 162p. Tese (Doutorado) - Universidade Federal do Rio Grande do Sul.

SPRACKLING, J.A. Soil topographic site index for engelmann spruce on granitic soils in Northern Colorado and Southern Wyoming. Washington: Forest Service, 1973. 4p. (Research Note, RM-239).

SPURR, S.H. Forest Ecology. New York: The Ronald, 1964. 352p.

SPURR, S.H.; BARNES, B.V. Forest Ecology. 3.ed. New York: John Wiley, 1980. $687 \mathrm{p}$.

STATSOFT. Statistica for windows, release 5.1: software de análise estatística (software). USA, 1993.

STENDAHL, J. Spatial variability within managed forest stands. In: INTERNATIONAL PRECISION FORESTRY COOPERATIVE SYMPOSIUM, 1., Seattle, 2001. Proceedings. Seattle: University of Washington College of Forest Resources, 2001. p.35-42.

STROTHMANN, R.O. Evaluating the growth potential of aspenlands in North Minnesotta. Station Paper, 86. Saint Paul: Lake States Forest Experiment Station, 1960. 20p. 
SUDDUTH, K.A.; FRAISSE, C.W.; DRUMMOND, S.T.; KITCHEN, N.R. Integrating spatial data collection, modeling and analysis for precision agriculture. In: SMITH, J.L.; S.P. PRISLEY. INTERNATIONAL CONFERENCE ON GEOSPATIAL INFORMATION IN AGRICULTURE AND FORESTRY, 1., Lake Buena Vista, 1998. Proceedings. Lake Buena Vista: ERIM INT, 1998. v.2, p.166-173.

SUTCLIFEE, J.F. As plantas e a água. São Paulo: EPU, 1980. 126p.

TABOR, J.A.; WARRICK, A.W.; PENNINGTON, D.A.; MYERS, D.E. Spatial variability of nitrate in irrigated cotton: I. Petioles. Soil Science Society of America Journal, v.48, p.602-607, 1984.

TEIXEIRA, J.B. Efeito do déficit hídrico sobre a fotossíntese, a respiração e a eficiência no uso da água, em seis espécies de leguminosas forrageiras. Viçosa, 1978. 45p. Dissertação (Mestrado) - Universidade Federal de Viçosa.

TEIXEIRA, J.L. Conteúdo de nutrientes e produção de eucalipto em diferentes ambientes do Rio Doce, MG. Viçosa, 1987. 70p. Dissertação (Mestrado) - Universidade Federal de Viçosa.

TESCH, S.D. The evalution of forest yield determination and site classification. Forest Ecology Management, n.3, p.169-182, 1981.

THONSON, G.W.; MCCOMB, A.L. Growth of plantation black walnut in relation to $\mathrm{pH}$ and certain chemical factors of the soil. Forest Science, v.8, n.4, p.322-333, 1962.

THWAITES, R.N.; SLATER, B.K. Soil-landscape resource assessment for plantations a conceptual framework towards an explicit multi-scale approach. Forest Ecology and Management, v.138, n.1/3, p.123-138, nov. 2000.

TORRADO, P.V. Relações solo x relevo em Mococa (SP): Influência das características topográficas e posição na vertente nos atributos do solo. Piracicaba, 1989. 205p. Dissertação (Mestrado) - Escola Superior de Agricultura "Luiz de Queiroz", Universidade de São Paulo.

TORRES, F.T.; PROCHNOW, L.I. Mapeamento de fertilidade do solo. In: L.A. Balastreire. In: BALASTREIRE, L.A. O estado da arte da agricultura de precisão no Brasil. Piracicaba: O autor, 2000. p.85-87. 
TRANGMAR, B.B.; YOST, R.S.; WADE, M.K.; UEHARA, G. Applications of geostatistics to spatial studies of soil properties. Advances in Agronomy, v.38, p.45-94, 1985.

TRANGMAR, B.B.; YOST, R.S.; WADE, M.K.; UEHARA, G.; SUDJADI, M. Spatial variation of soil properties and rice yield on recently cleared land. Soil Science Society of America Journal, v.51, p.668-674, 1987.

TRIMBLE JUNIOR, G.R.; WEITZMAN, S. Site index studies of Uplands Oaks in the Northern Appalachians. Forest Science, v.2, n.3, p.163-172, 1956.

TUBELIS, A.; NASCIMENTO, F.J.L. Meteorologia descritiva: fundamentos e aplicações brasileiras. São Paulo: Nobel, 1983. 374p.

ULRICH, B.; MAYER, R.; KHANNA, P.K. Chemical changes due to acid precipitation in a loess-derived soil in Central Europe. Soil Science, v.130, p.193-199, 1980.

VAUCLIN, M.; VIEIRA, S.R.; VACHAUD, G.; NIELSEN, D.R. The use of cokriging with limited field soil observations. Soil Science Society of America Journal, v.47, p.175-184, 1983.

VEIGA, A.A. Coletânea de assuntos técnicos: área de dasonomia. São Paulo: Instituto Florestal, 1985. 139p.

VENTURI, N.L. GIS aplicado na área florestal (compact disc). In: SEMINÁRIO DE ATUALIZAÇÃO EM SENSORIAMENTO REMOTO E SISTEMAS DE INFORMAÇÕES GEOGRÁFICAS APLICADOS A ENGENHARIA FLORESTAL, 4., Curitiba, 2000. Anais. Curitiba, 2000.

VETTORAZZI, C.A.; FERRAZ, S.F.B. Silvicultura de precisão: uma nova perspectiva para o gerenciamento de atividades florestais. In: BORÉM, A.; GIUDICE, M.P.; QUEIRÓZ, D.M. de; et al. (Ed.). Agricultura de Precisão. Viçosa: Os autores, 2000. p.65-75.

VIEIRA, S.R. Geoestatística em estudos de variabilidade espacial. In: CURSO DE ATUALIZAÇÃO EM CONSERVAÇÃO DO SOLO, Campinas, 1995. Apostila. Campinas: IAC, 1995. 61p. 
VIEIRA, S.R. Variabilidade espacial de argila, silte e atributos químicos em uma parcela experimental de um latossolo roxo de Campinas (SP). Bragantia, v.56, n.1, p.181190, 1997.

VIEIRA, S.R. Geoestatística em estudos de variabilidade espacial. Campinas: IAC, 1998.

VIEIRA, S.R. Geoestatística aplicada a agricultura de precisão. In: BORÉM, A.; GIUDICE, M.P.; QUEIRÓZ, D.M. de; et al. (Ed.). Agricultura de Precisão. Viçosa: Os autores, 2000. p.93-108.

VIEIRA, S.R.; LOMBARDI NETO, F. Variabilidade espacial do potencial de erosão das chuvas do Estado de São Paulo. Bragantia, v.54, n.2, p.405-412, 1995.

VIEIRA, S.R.; DECHEN, S.C.F.; MARIA, I.C. de. Uso de geoestatística no mapeamento de atributos de solo e planta (compact disc). In: CONGRESSO E FEIRA PARA USUÁRIOS DE GEOPROCESSAMENTO DA AMÉRICA LATINA - GIS BRASIL 98, 4., Curitiba, 1998. Anais. Curitiba, 1998.

VIEIRA, S.R.; NIELSEN, D.R.; BIGGAR, J.W. Spatial variability of field-measured infiltration rate. Soil Science Society of America Journal, v.45, n.6, p.1040-1048, 1981.

VIEIRA, S.R.; HATFIELD, J.L.; NIELSEN, D.R.; BIGGAR, J.W. Geostatistical theory and application to variability of some agronomical properties. Hilgardia, v.51, n.3, p.1-75, 1983.

VIEIRA, S.R.; DE MARIA, I.C.; CASTRO, O.M. de; DECHEN, S.C.F.; LOMBARDI NETO, F. Utilização da análise de Fourier no estudo do efeito residual da adubação em uva na crotalária. Revista Brasileira de Ciência do Solo, v.11, n.7, p.7-10, 1987.

VIEIRA, S.R.; DECHEN, S.C.F.; MARIA, I.C. de; MARTINS, A.L.M.; BORTOLETTO, N. Mapeamento de atributos de solo e plantas usando geoestatística. In: BALASTREIRE, L.A. O estado da arte da agricultura de precisão no Brasil. Piracicaba: O autor, 2000. p.93-104.

ZAHNER, R. Site-quality relationships of pine forest in Southern Arkansas and Northern Louisiana. Forest Science, v.4, n.2, p.162-176, 1958. 
ZAHNER, R. Loblolly pine site curves by soil groups. Forest Science, v.8, n.2, p.104 110, 1962.

YOST, R.S.; UEHARA, G.; FOX, R.L. Geostatistical analysis of soil chemical properties of large land areas. II. Kriging. Soil Science Society of America Journal, n.46, p.1033-1037, 1982.

WARRICK, A.W.; NIELSEN, D.R. Spatial variability of soil physical properties in the field. In: HILLEL, D. Applications of soil physics. New York: Academic Press, 1980. 385p.

WEBSTER, R. Quantitative spatial analysis of soil in field. Advances in Soil Science, V.3, p.1-70, 1985.

WEBSTER, R.; OLIVER, M.A. Statistical methods in soil and land resource survey. Oxford: Oxford University Press, 1990. 316p. 